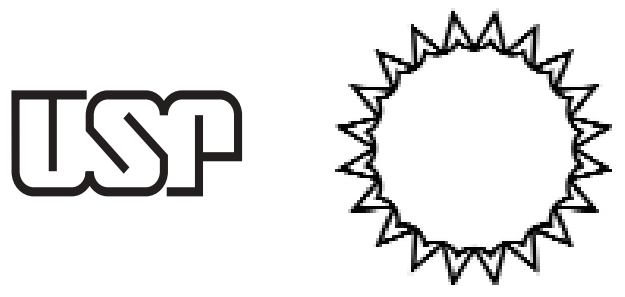

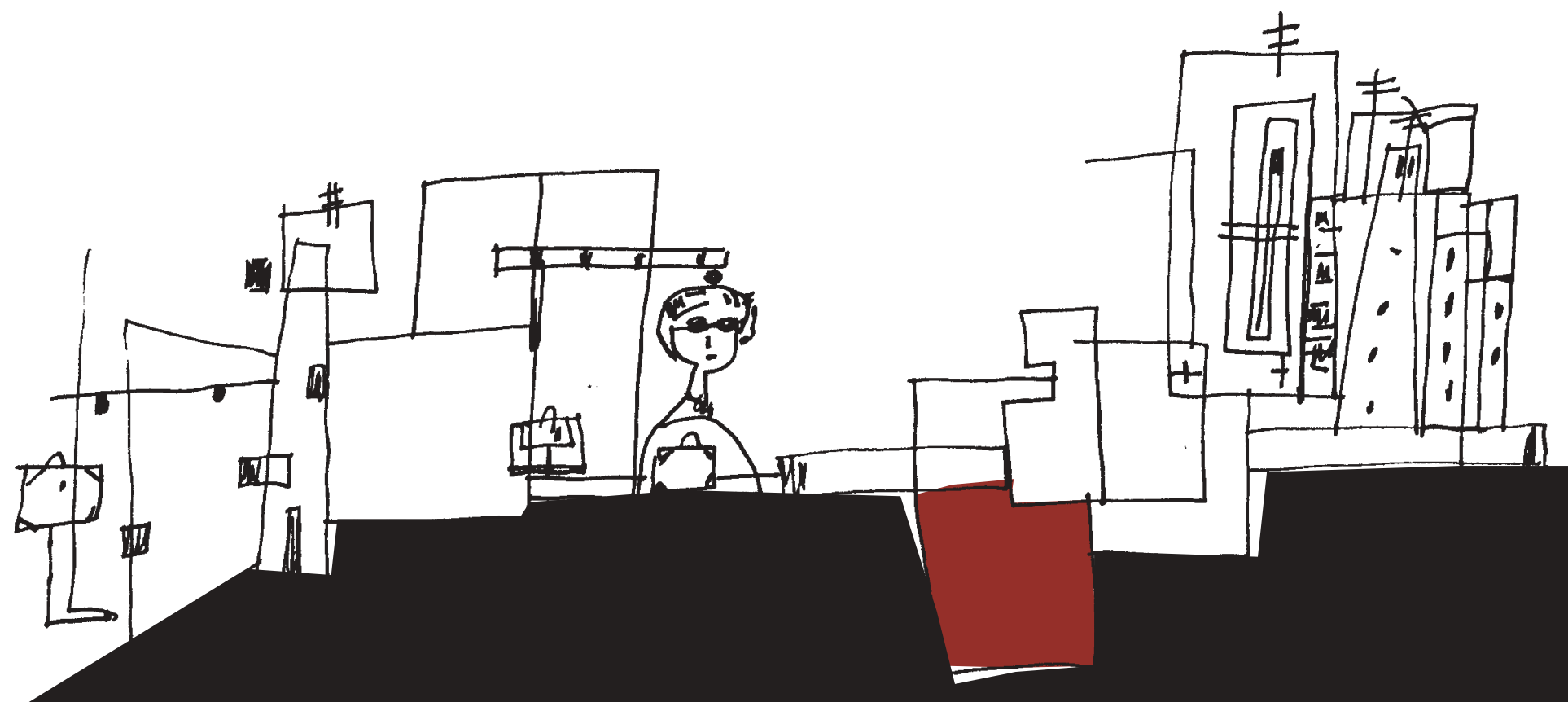

\section{Conforto térmico}

e eficiência energética em Hotéis Econômicos

Anarrita Bueno Buoro 




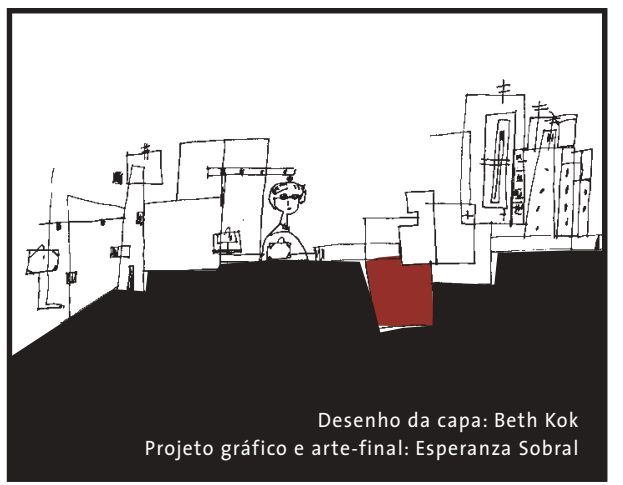




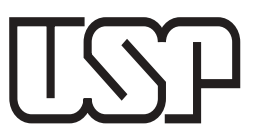

UNIVERSIDADE DE SÃO PAULO - FACULDADE DE ARQQUITETURA E URBANISMO PROGRAMA DE PÓS GRADUAÇÃO

\title{
Conforto térmico \\ e eficiência energética em Hotéis Econômicos
}

\author{
Anarrita Bueno Buoro \\ Orientadora Profa. Dra. Márcia Peinado Alucci
}

Apoio:

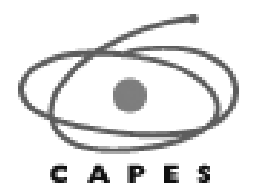

2008

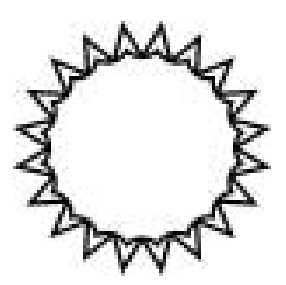

FAUUSP 



\title{
Conforto térmco e eficiência energética em Hotéis Econômicos
}

\author{
Dissertação de Mestrado apresentada na \\ Faculdade de Arquitetura e Urbanismo da \\ Universidade de São Paulo, para obtenção do título \\ de mestre em Arquitetura e Urbanismo. \\ Área de Concentração: Tecnologia da Arquitetura \\ Orientadora: Profa. Dra. Márcia Peinado Alucci
}


AUTORIZO A REPRODUÇÃO E DIVULGAÇÃO TOTAL OU PARCIAL DESTE TRABALHO, POR QUALQUER MEIO CONVENCIONAL OU ELETRÔNICO PARA FINS DE ESTUDO E PESQUUISA, DESDE QUUE CITADA A FONTE.

assinatura: Anado Buen Buovo

E-MAIL: ritabuoro@usp.br

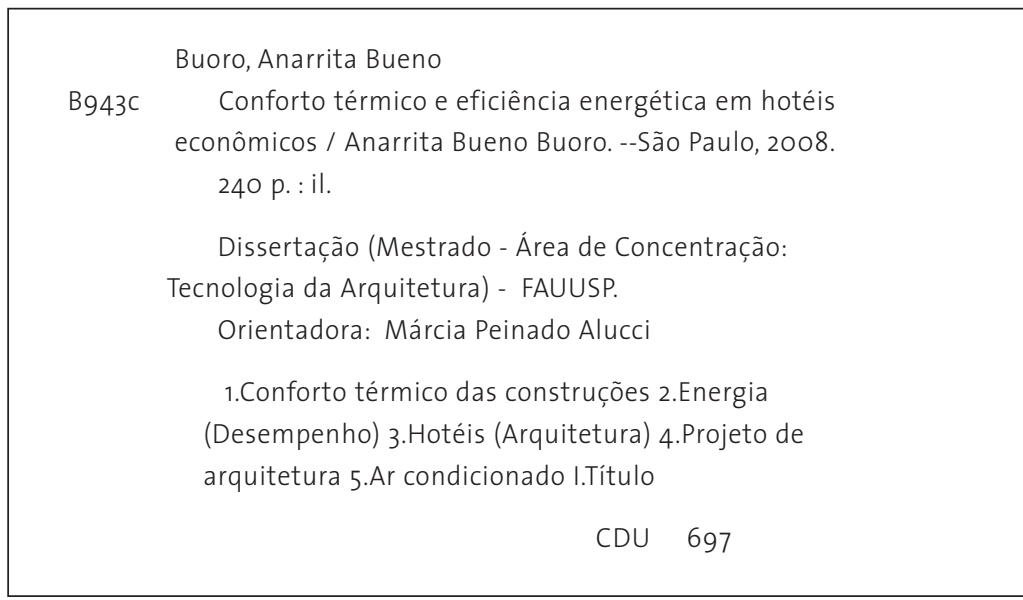

NOTAS:

Todas as ilustraç̃es sem indicação de fonte são da autora.

Todas as citações cujo original está na lingua inglêsa foram traduzidas pela autora. 


\section{Folha de aprovação}

Anarrita Bueno Buoro

Conforto térmico e Eficiência Energética em Hotéis Econômicos

Dissertação de Mestrado apresentada na Faculdade de Arquitetura e Urbanismo da Universidade de São Paulo, para obtenção do título de mestre em Arquitetura e Urbanismo.

Área de Concentração: Tecnologia da Arquitetura

Aprovado em:

Banca Examinadora

$\operatorname{Prof}(a) \cdot \operatorname{Dr}(a)$.

Instituição: Assinatura:

$\operatorname{Prof}(a) \cdot \operatorname{Dr}(a)$.

Instituição: Assinatura:

Prof(a). Dr(a).

Instituição: Assinatura:

Prof(a). Dr(a).

Instituição: Assinatura:

Prof(a). Dr(a).

Instituição: Assinatura: 

Aos meus avós queridos, onde estiverem...

Aos meus pais, Alvaro e Anamelia, pela educação e incentivo A minha família, Fernando, grande amor e companheiro da minha vida. E aos meus filhos;

Tales, por sua existência... alegria e curiosidade. E o "bebezinho" que está por vir, por vivenciar, mais que ninguém, as minhas emoções no final deste trabalho... 



\section{Agradecimentos}

Contei como apoio e colaboração de diversas pessoas e instituições, a quem gostaria de expressar meu sincero reconhecimento:

À minha orientadora, Professora Dra. Márcia Peinado Alucci, por todo ensinamento, valiosa orientação, dedicação e também amizade.

Ao meu co-orientador, Professor Dr. Fulvio Vitorino, por me introduzir a paixão pelos sistemas de ar condicionado, e pelas valiosas contribuições em todo trabalho, especialmente durante a realização das medições.

À Professora Dra. Joana Gonçalves, pelas importantes conversas, e colocações durante todo mestrado.

À Professora Dra. Denise Duarte, pelas importantes colocações durante a banca de qualificação.

Ao Professor Dr. Alberto Hernandez Neto, pelas inúmeras aulas e atendimentos sobre os sistemas de ar condicionado, pelo curso de simulação do Energy Plus, e pelas importantes colocações durante a banca de qualificação.

À Professora Dra. Anésia Frota, pelo empréstimo de alguns dos equipamentos utilizados nas medições, sua disponibilidade e interesse nos resultados, assim como pelo espaço de sua casa que foi ocupado para o abrigo de alguns destes equipamentos.

Aos Professores do LABAUT, Roberta Kronka e Fernando Cremonesi, por compartilhar o conhecimento e amizade.

Ao Engenheiro Carlos Martins, por todo o tempo disponível dedicado que me introduziu no setor hoteleiro, e nos hotéis da rede Accor.

Aos professores das disciplinas cursadas, Dr. Arlindo Tribess, Dra. Brenda 
Leite pelo incentivo e dedicação.

À arquiteta Carolina Gaspar Leite, irmã de coração e companheira de pesquisa, pela amizade e apoio durante todo o mestrado e cujo incentivo foi fundamental durante muitos momentos.

Aos arquitetos e amigos do LABAUT que participaram diretamente com valiosas contribuições para este trabalho: Gisele De Benedetto, Mônica Marcondes, Cecília Mueller, Andréa Bazarian, Bruna Luz, Alessandra Prata, Norberto Moura, Rafael Brandão, Daniel Cóstola, Leonardo Monteiro, Érika Eumakoshi e Rodrigo Castro Cavalcante.

Aos amigos do LABAUT, pesquisadores e companheiros: Anna Miana, , Joerg Spangenberg, Erik Johansson, Cíntia Figueiredo, Daniela Laudares, Paula Skinzato, Luciana Costa e Simone Büttner.

Aos colegas de diversas disciplinas, Maria Julia de Mesquita, Cristina Kawakita Marcelo Jun Ikeda, Hermínia Machy, bem como os colegas da Engenharia Mecânica da POLI, Marcelo Luiz Pereira e Vitor Barbosa Felix.

Pela disponibilidade e atenção dos amigos para pernoitar durante o período de medição no Hotel, mesmo com as restrições impostas pela pesquisa, que não as deixou desfrutar de tanta liberdade durante a estada: Bruna Luz, Sahra Luz, Anelise Steiner e Elielma Luiza da Silva.

Às secretárias do Departamento de Tecnologia da FAU/USP, em especial Silvana Marques, Liliana Alves e Maria Lúcia Vieira, pela constante simpatia e disposição; e aos assistentes do LABAUT, Alessandra Vialogo, Luiz Alberto Pignatari e Carlos Bayer.

À Eliana Athie, Bia Costa, Norberto Moura e Alessandra Prata pelas valiosas contribuições na revisão de texto.

À Beth Kok e Esperanza Sobral, do Estúdio Girassol, pela dedicação e auxílio na formatação e capa.

Aos professores do CECACE III/FUPAM, que me introduziram de volta à academia, e despertaram o interesse inicial para esta nova etapa de pesquisa.

Ao Senhor Airton Dantas e Cleison Freitas, gerentes do Hotel - estudo de caso, por todo apoio e interesse durante a pesquisa de campo no Hotel. E também ao responsável pela manutenção, Airton, pelo seu apoio e dedicação.

A toda minha família, em especial minha mãe Anamélia Buoro, irmãos Andréa Bueno Buoro e Álvaro Bueno Buoro pelas revisões e discussões sobre o trabalho.

À família Spalding, em especial ao Fernando Spalding, Eduardo Spalding, pelas ricas discussões sobre o trabalho. E também Eduardo Sergio Spalding pelo tratamento de algumas imagens do texto. 
Ao meu pai, Alvaro Buoro e minha sogra, Carmen Spalding, pelo apoio indireto, especialmente com o Tales.

A Fernando, pelo apoio incondicional em todos os momentos, pelo amor e companherismo.

Ao Tales, por saber lidar com a minha ausência em muitos momentos deste percurso e presentear-me com seu amor.

Ao "bebezinho" que conviveu intensamente com todas as minhas emoções na etapa final deste trabalho, e espera pacientemente a sua hora para vir ao mundo.

À NCEUB (The Network of Comfort and Energy Use in Building) e à LMU (London Metropolitan University), pelo apoio financeiro para participar da Windsor Conferencer em abril de 2006.

Ao LABAUT, pelo empréstimo de alguns dos equipamentos utilizados nas medições.

Ao IPT - Instituto de Pesquisas Tecnológicas, pelo empréstimo de alguns dos equipamentos utilizados nas medições.

Ao IAG USP - Instituto de Astronomia, Geofísica e Ciências Atmosféricas da Universidade de São Paulo, pelo fornecimento de dados da estação meteorológica Parque do Estado.

À CAPES - Coordenação de Aperfeiçoamento do Pessoal de Nível Superior pelo apoio financeiro. 

(...) não é verdade que o teto da nossa casa é o piso da casa do titio que mora em cima e o piso da nossa casa é o teto do titio que mora em baixo?

Tales Bueno Buoro Spalding (aos 2,3 anos) 



\section{Resumo}

BUORO, Anarrita Bueno. Conforto térmico e eficiência energética em Hotéis

Econômicos. 2008. 240 p. Dissertação (Mestrado). Faculdade de Arquitetura e Urbanismo, Universidade de São Paulo, São Paulo, 2008.

Este trabalho busca avaliar a eficiência energética e o conforto, em ambiente climatizado artificialmente, dos Hotéis Econômicos de redes internacionais em São Paulo. A avaliação levada a cabo concentrou-se nas unidades habitacionais (UH) desses hotéis, principal produto oferecido por eles, possuidoras de sistema de ar condicionado (SAC), apesar das condições climáticas e das características do uso não determinarem essa necessidade.

Com base nos levantamentos sobre as características dos Hotéis Econômicos, foi escolhido um hotel de uma rede internacional em São Paulo como estudo de caso. Nele, avaliou-se o desempenho térmico por meio de medições de temperatura e umidade relativa do ar em duas $\mathrm{UH}$, durante cinco dias. As características físicas desse hotel foram utilizadas como modelo-base para as simulações computacionais realizadas no software TAS NG (2005). A partir dos resultados obtidos nas medições, definiram-se os critérios que seriam utilizados nas variações do modelo paramétrico, resultando em um total de sete cenários, com diferentes características como: vidros, cortina interna, taxa de ventilação e período determinado para ventilação.

Levando-se em conta as condições climáticas da cidade de São Paulo e as características físicas e ocupacionais dos apartamentos, verificou-se que é possível obter conforto térmico sem o uso de SAC. Nessas condições, utilizou-se como critério de avaliação o modelo adaptativo da Norma ASHRAE 55 (2004). Os dados 
dos dias mais representativos de verão e inverno forma utilizados na análise dos ganhos de calor. Foi também avaliado, para o período de um ano, o consumo de energia elétrica do SAC, para resfriamento e aquecimento.

Os resultados obtidos auxiliaram na proposição de recomendações de projeto para essa tipologia, buscando soluções que aprimoram o aproveitamento das condições naturais favoráveis para a obtenção de conforto térmico, possibilitando a redução do consumo de energia decorrente do SAC nestes ambientes. Para ilustrar algumas recomendações foram feitos estudos preliminares para as UH e para o pavimento tipo, considerando a integração do SAC com soluções de projeto de arquitetura que favoreçam o melhor desempenho energético de Hotéis Econômicos ou de qualquer categoria.

Palavras Chave: Conforto Térmico, Eficiência Energética, Hotel, Hotéis Econômicos, simulação computacional, desempenho térmico, desempenho energético, qualidade ambiental, ar condicionado, projeto de arquitetura. 


\section{Abstract}

BUORO, Anarrita Bueno. Thermal comfort and energy efficiency in Budget

Hotels. 2008. 240 p. Dissertation (Master). Faculdade de Arquitetura e Urbanismo, Universidade de São Paulo, São Paulo, 2008.

This work aims to evaluate the energy efficiency and comfort level, in airconditioned environments of budget hotels, from international chains, in São Paulo, Brazil. The evaluation was directed to the apartments which are the hotel's main product featuring air conditioning, even though the climate conditions and usage profile don't determine its need.

One hotel from an international chain was chosen as a case study based on research of budget hotel's main features. The hotel had its thermal performance evaluated through air temperature and humidity measurements, in two apartments, for five days. Its physical characteristics were inputted into the TAS NG (2005) software as a base model for simulations. The measurements results defined the criteria used in the parametric model, resulting in a total of seven scenarios with different characteristics such as glass, internal shades, ventilating rates and period.

Considering São Paulo's climatic conditions, the physical and occupational characteristics of the apartments, it was verified that it is possible to reach thermal comfort without the use of air conditioning. The evaluating criterion used in these conditions was an adaptive model from the ASHRAE 55 (2004) Norm. Data from the most representative days of summer and winter were used in the analysis. There was also an evaluation of the energy consumption of the air condition- 
ing system, used for cooling and heating purposes, for a period of one year.

The results favored the proposal for project recommendations for this typology, seeking solutions to improve the capacity to harness the favorable natural conditions to obtain thermal comfort, allowing for energy consumption reduction due to air conditioning.

To illustrate the recommendations some preliminary studies were prepared for the apartments and pavement type, considering the integration of the air conditioning system with architectural design solutions that favor a better energy performance of budget hotels or of any other category.

Key Words: Thermal Comfort, Energy Efficiency, Hotels, Computational Simulation, Thermal Performance, Energy Performance, Environmental Quality, Air Conditioning, Architectural Project. 


\section{Lista de ilustrações}

Ilustração 1: Energia consumida no ciclo de vida de um edifício $\ldots \ldots \ldots \ldots 3$

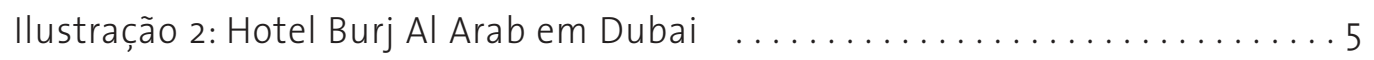
Ilustração3: Distribuição do consumo por uso final - Setor Comercial . . . . . . 7 Ilustração4: Diagrama da estrutura da dissertação $\ldots \ldots \ldots \ldots \ldots \ldots \ldots \ldots \ldots$ Ilustração 5: Seqüência das variáveis na etapa da avaliação paramétrica . . . 12 Ilustração 6: Apartamento do Hotel de gelo onde o hóspede dorme em UH com a temperatura do ar estimada em menos cinco graus Celsius ............. 14 Ilustração 7: Hierarquia da classificação das categorias hoteleiras representadas por símbolos ........................................ 19

Ilustração 8: Hotel econômico em São Paulo (9 andares superiores) e escritórios (8 andares inferiores): sistema split com leitura individual $\ldots \ldots \ldots \ldots 25$

Ilustração 9: Condensador(a)com acesso restrito para equipe de manutenção (b) . . 25 Ilustração 10: Hotel Cube - Savognin (Europa): opção de quarto para duas ou quarto pessoas (a e b, respectivamente); atrium central espaçoso com restaurante,

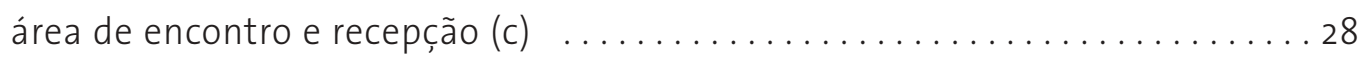
Ilustração 11: Hotel Cube - Savognin (Europa): segundo piso(a), primeiro piso(b)

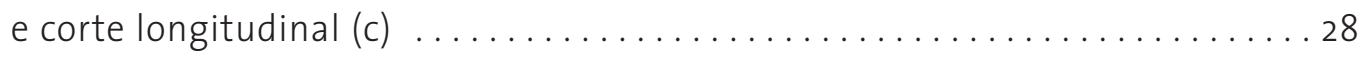
Ilustração 12: Hotel Braumaunufaktur, Alemanha: desenho de mobiliário compacto com armário e bancada de um lado da cama (a), e camas extras embutidas (b, do outro lado 29 
Ilustração 13: Hotel Braumaunufaktur, Alemanha: corredor (a), vista externa (b) e planta (c) ....................................................

Ilustração 14: "Five + Sensotel”, Suiça: atmosfera tranqüila (a) e cabeceira com

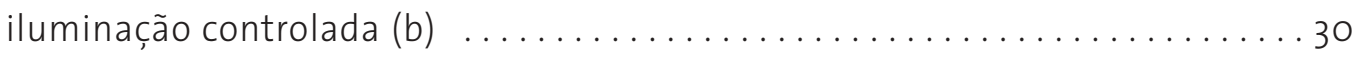

Ilustração 15: Corte esquemático com as estratégias da Torre Shiodome . . . 332 Ilustração 16: Apartamento do Hotel Shiodome no Japão- modelo 1 . . . . . 33 Ilustração 17: Apartamento do Hotel Shiodome no Japão- modelo 2_durante o dia . . 33 Ilustração 18: Apartamento do Hotel Shiodome no Japão- modelo 2_durante

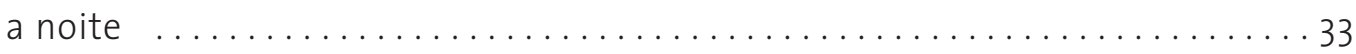

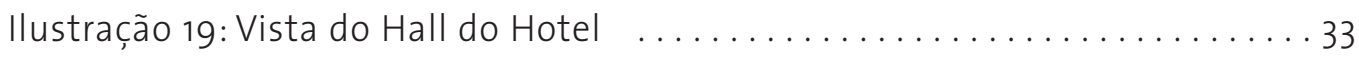

Ilustração 20: Vista do edifício Skiodome no Japão (hotel e escritório) … . 33 Ilustração 21: Vista aérea da Torre Shiodome com destaque para formato da

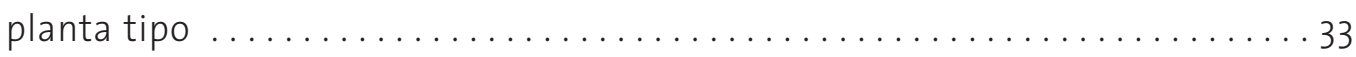

Ilustração 22: Hote Ibis Casa Verde (a) e Íbis Santos Dumont (b): rede Accor . 37 Ilustração 23: Grupo Accor: Hotel Ibis I, São Paulo (a) Hotel Ibis Maceió (b),

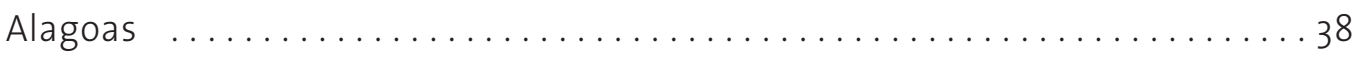

Ilustração 24: Mapa da implantação dos hotéis nas décadas de 70 e $80 \quad \ldots 39$ Ilustração 25: Mapa da implantação dos hotéis na década de $90 \ldots \ldots . \ldots 39$ Ilustração 26: Mapa de renda e distribuição dos meios de hospedagem em

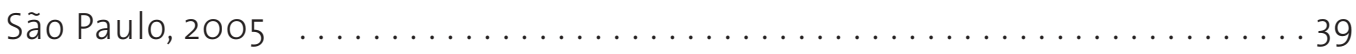

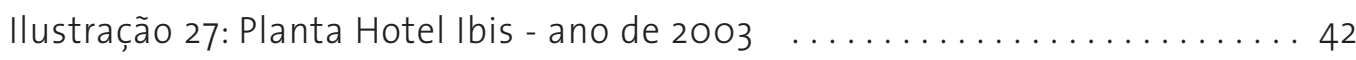

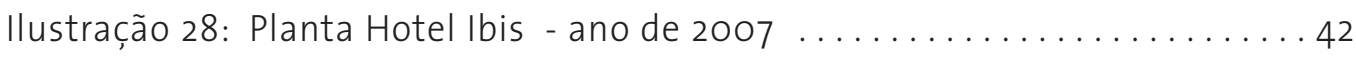

Ilustração 29: Inter-relações espaciais básicas do setor de hóspedes $\ldots \ldots 43$

Ilustração 30: Exemplo das dimensões das UH dos Hotéis Econômicos . . . . 44 Ilustração 31: Percentual de empresas brasileiras do Setor Comercial que dispõem de sistemas de ar condicionado e/ou ventilação . . . . . . . . . . . . . . 47 Ilustração 32: Porcentagem da posse média de ar condicionado no setor comercial

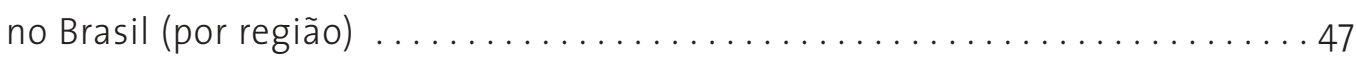
Ilustração33: Requisito votado como indispensável em Hotel Econômico . . . . 48 Ilustração 34: Hotel Íbis Expo - capital (a) com 12 andares e Ibis Piracicaba, interior

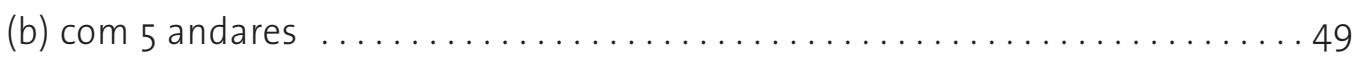

Ilustração 35: Planta Padrão do Hotel Íbis (2007) . .................... 50 


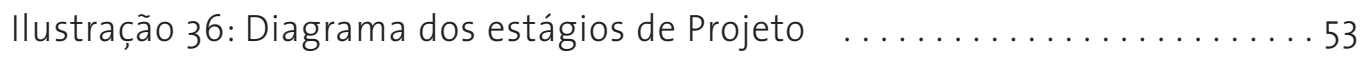
lustração 37: Seqüência metodológica de projeto proposta $\ldots \ldots \ldots \ldots$ lustração 38: Diagnóstico climático de São Paulo- método GIVONI … .... 59 Ilustração 39 Diagnóstico climático de São Paulo, com separação do período de

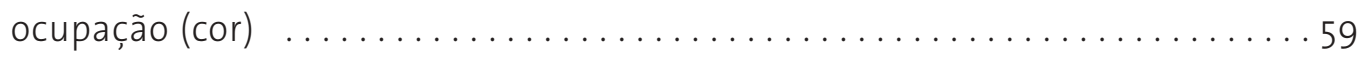
Ilustração 40: Gráfico de variáveis na escala de conforto modificado por Fanger .. 74 Ilustração 41: Comparação dos limites de temperatura de conforto pelo modelo da ASHRAE 55 (2004) com o modelo de Humphreys (1978) ..............68 68 Ilustração 42: Comportamento do fluxo de ar em torno de edificações . . . . 70 70 Ilustração 43: Átrio central do Hotel Burj al Arab em Dubai, vista aérea. . . . . . 78 Ilustração 44: Átrio central do Hotel Burj al Arab em Dubai, vista do terreo.. . . 78 Ilustração 45: Recomendação de nova alternativa para aproveitamento da ventilação natural sem prejudicar o nível de ruído nem a qualidade do ar interna

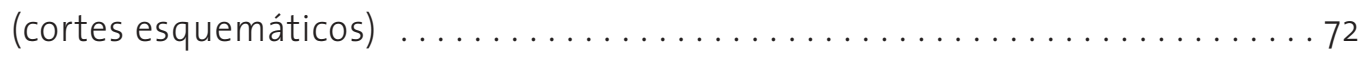

Ilustração 46: Variáveis na condutibilidade térmica dos elementos translúcidos …73 Ilustração 47: Curva de eficiência de um chiller com várias combinações de condensadores pela carga parcial do chiller, considerando a temperatura externa

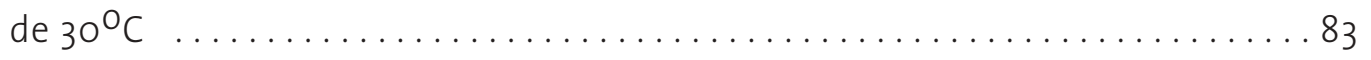
Ilustração 48: Exemplos de edifícios de escritório (Torre Norte) e hotel na cidade de São Paulo com arquitetura "internacional" ................... 81 Ilustração 49: Exemplos de hotel em São Paulo: com vidros refletidos e varandas . 81 Ilustração 50: Exemplos de hotel com vidros verde e cortina black out (internas) . . 81 Ilustração 51: Plantas do $1^{\circ}$ ao $12^{\circ}$ pavimento (lado esquerdo) e do $13^{\circ}$ pavimento (lado direito) em estudo de Hotel Econômico, com indicação de cores diferentes de acordo com a diferença na carga térmica ..................... 84 Ilustração 52: Edifício Commerzbank HQ, Frankfurt, Alemanha (construído

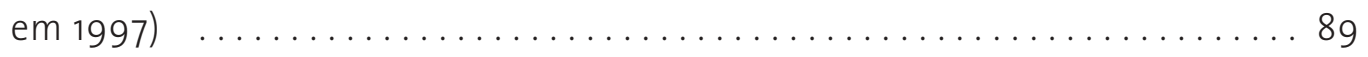

Ilustração 53: Edifício Swiss Re, Londres, Inglaterra (construído em 2004) .. 89 Ilustração 54: Variação da temperatura de acordo com as estratégias de projeto comparadas com o modo misto ............................ 89 Ilustração 55: Comparação entre as diferenças principais do condicionamento natural, artificial e modo misto ............................. 91 
Ilustração 56: Relação das áreas de aberturas com consumo de energia elétrica para iluminação artificial (kWh/mês) e para o condicionamento artificial

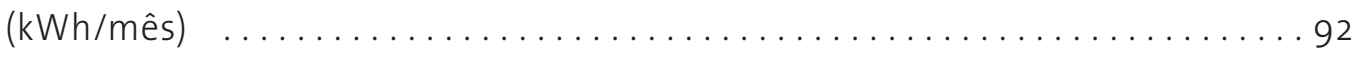

Ilustração 57: Efeito da forma da abertura em função da direção do vento e da existência de protetores solares verticais $\ldots \ldots \ldots \ldots \ldots \ldots \ldots \ldots \ldots \ldots \ldots \ldots \ldots \ldots$

Ilustração 58: Distribuição da luz natural pela distância da janela, e a integração

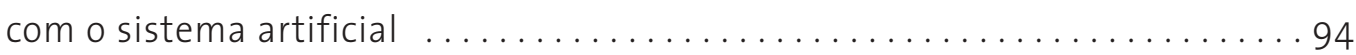

Ilustração 59: Melhor desempenho térmico e Luminoso: a integração da ilumi-

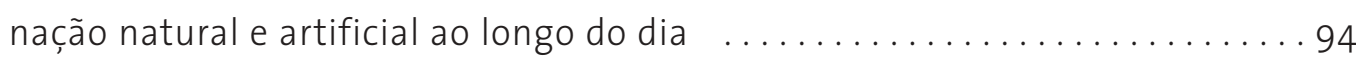

Ilustração 60: Seqüência detalhada das variáveis simuladas .............999 Ilustração 61: Ano climático de referência para São Paulo com indicação dos limites de conforto: Temperatura do ar (TBS) . .................... 101 Ilustração 62: Ano climático de referência para São Paulo com indicação dos limites de conforto: Umidade Relativa do ar (UR) . . . . . . . . . . . . . . 101 Ilustração 63: TBS do mês mais crítico de verão com TC (Fevereiro) . . . . . . 102 Ilustração 64: TBS do mês crítico de inverno com TC (Agosto) . . . . . . . . . . 102 Ilustração 65: Freqüência de ocorrência de temperatura no mês de Agosto . 104 Ilustração 66: Freqüência de ocorrência de temperatura no mês de Fevereiro 104 Ilustração 67: Dia médio do mês mais quente (verão) e dia representativo de verão - dia 51 do arquivo climático utilizado ......................... 105 Ilustração 68: Dia médio do mês mais frio (inverno) e dia representativo de

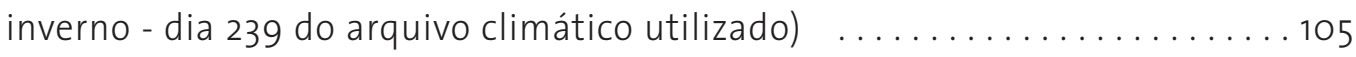
Ilustração 69: TBS externo de TBS interno (face E e O)- dados empíricos e simulados .......................................... 109 Ilustração 70: TBS externo de TBS interno (face NE e S O)- dados empíricos e

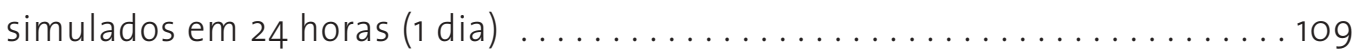
Ilustração 71: TRM dados empíricos e simulados $\ldots \ldots \ldots \ldots \ldots \ldots \ldots \ldots \ldots . \ldots \ldots$ Ilustração 72: Balanço horário de fevereiro, com 10\% de insatisfeitos . . . . . 116 Ilustração 73: Ganhos e Perdas do Cenário o- verão …................ 118 Ilustração 74: Ganhos e Perdas do Cenário o- inverno ...................118 Ilustração 75: Variação da temperatura interna e externa no dia representativo de verão e inverno - Cenário o ................................... 119 
Ilustração 76: Ganhos e Perdas do Cenário 1- verão . . . . . . . . . . . . . . 119

Ilustração 77: Ganhos e Perdas do Cenário 1- inverno ................. 120

Ilustração 78: Ganhos e Perdas do Cenário 2- verão ................... 120

Ilustração 79: Ganhos e Perdas do Cenário 2- inverno ................. 121

Ilustração 80: Ganhos e Perdas do Cenário 3- verão …............... 122

Ilustração 81: Ganhos e Perdas do Cenário 3 - inverno . . . . . . . . . . . 122

Ilustração 82: Variação da temperatura externa e interna no dia representativo de

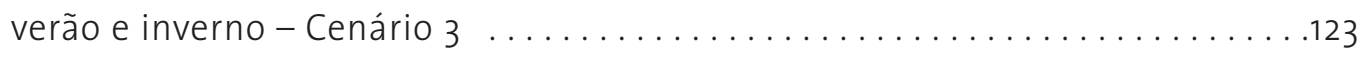

Ilustração 83: Ganhos e Perdas do Cenário 4-verão . . . . . . . . . . . . . 123

Ilustração 84: Ganhos e Perdas do Cenário 4- inverno ................. 124

Ilustração 85: Ganhos e Perdas do Cenário 5- verão . . . . . . . . . . . . . . . 124

Ilustração 86: Ganhos e Perdas do Cenário 5- inverno .................. 125

Ilustração 87: Ganhos e Perdas do Cenário 6- verão . . . . . . . . . . . 126

Ilustração 88: Ganhos e Perdas do Cenário 6- inverno ................. 126

Ilustração 89: TBS interna e externa e carga Latente e Sensivel nos dias representativos de inverno e de verão - Cenário $6 \ldots \ldots \ldots \ldots \ldots \ldots \ldots \ldots \ldots \ldots \ldots \ldots \ldots \ldots \ldots \ldots$

Ilustração 90: TBS interna e externa e carga Latente e Sensível nos dia s representativos de inverno e de verão - Cenário $\ldots \ldots \ldots \ldots \ldots \ldots \ldots \ldots \ldots \ldots \ldots \ldots \ldots$

Ilustração 91: Carga sensível (SAC) para todos os Cenários simulados . . . . . 128 Ilustração 92: Interpretação de Leonardo da Vinci do Homem de Vitruvius, com as

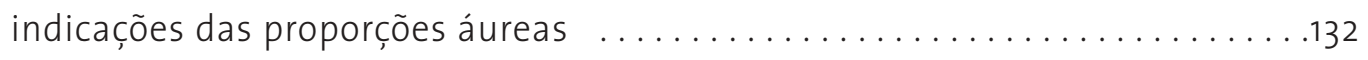

Ilustração 93: Comparação entre aspectos positivos e negativos da planta padrão

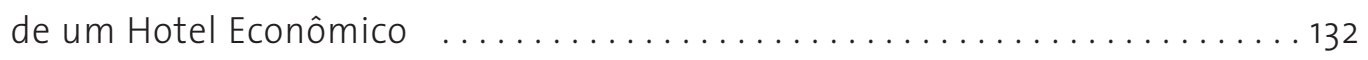

Ilustração 94: Planta do pavimento-tipo - Opção A … . . . . . . . . . 135

Ilustração 95: Corte esquemático - Opção A ….................. 136

Ilustração 96: Planta do pavimento-tipo - Opção B . . . . . . . . . . . . 136

Ilustração 97: Perspectiva das Fachadas - Opção A … . . . . . . . . . . 137

Ilustração 98: Perspectiva das Fachadas - Opção B . . . . . . . . . . . . . 138

Ilustração 99: Planta da UH - Opção 1 . . . . . . . . . . . . . . . . . . 139

Ilustração 100: Vista da UH - Opção 1 ............................. 139

Ilustração 101: Planta da UH - Opção 2 . . . . . . . . . . . . . . . . 140 


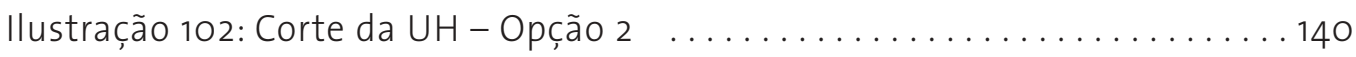

Ilustração 103: Perspectiva de sistema de ventilação com SAC . . . . . . . . . 141 Ilustração 104: Corte esquemático de sistema para melhorar o aproveitamento da ventilação natural ...................................... 142

Ilustração 105: Posição dos sensores normatizada pela ISO7726/98 para medição dos parâmetros físicos do ambiente homogêneo . . . . . . . . . . . . . . . 169

Ilustração 106: Planta dos apartamentos do estudo de caso com posicionamento dos sensores nos pontos A(quarto 765) e B, C e D (quarto 766) ........... 169

Ilustração 107: Data Logger AIMEMO 2290-8 com sonda de TBS e UR ALMEMO e termopar ........................................... 170

Ilustração 108: Termômetro e termopar dentro do globo suspensos por tripé . 171 Ilustração 109: Termopar na sobre a bancada de trabalho da UH (indicado em amarelo) ....................................... 171

Ilustração 110: Termopar posicionado na parte externa da fachada (indicado em vermelho) ......................................... 171

Ilustração 111: Planta do pavimento tipo com sobreposição da carta solar para verificação do período de insolação em cada face . . . . . . . . . . . . . 171

Ilustração 112: Indicação do apartamento 765 na fachada NE . . . . . . . . 172 Ilustração 113: Indicação do apartamento 766 na fachada SO . . . . . . . 172 Ilustração 114: Localização dos três pontos (indicados em amarelo) ... . . 172 Ilustração 115: Abrigo meteorológico para proteção dos equipamentos - ponto 2 . 173 Ilustração 17: Equipamentos do ponto 2: Termômetro de bulbo seco e úmido, acima, e na frente, o termógrafo bimetálico . .................... 173 Ilustração 117: Ciclo de medições realizado com Data Logger Almemo dos três dias em que foram considerados com geração de carga interna nas UH . . . . . . 179 Ilustração 118: Comparação das medições externas realizadas em diferentes equipamentos (Termógrafo Bimetálico, Data Logger Almemo) . . . . . . . . . . 181 Ilustração 119: Comparação das medições externas realizadas em diferentes equipamentos (Data Logger Almemo, no ponto 1, e estação meteorológica IAG, no

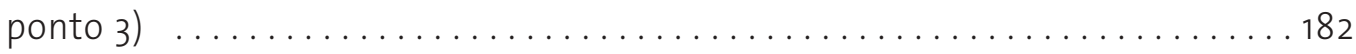
Ilustração 120: Medidas internas: temperatura do ar (TBS) e temperatura de

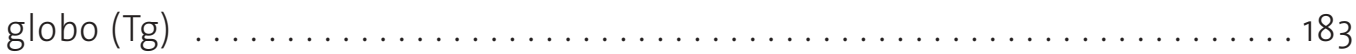
Ilustração 121: Medidas internas e externas (com data logger Almemo e estação 
meteorológica IAG) 184

Ilustração 122: Temperaturas internas medidas no dia 11/1com valores de TBS e TRM nas faces SO e NE, com indicação do período de ocupação e acionamento de equipamentos e lâmpadas 185

Ilustração 123: Comparação das medidas internas (face SO) no centro do quarto e na bancada com a medida externa da Estação Meteorológica IAG USP . . . . 186 Ilustração 124: Temperatura do ar (TBS) do dia 11/01, medido, com os limites da zona de conforto determinadas pela ASHRAE 55 (2004) ............... 189 Ilustração 125: Vestimenta de dormir dos ocupantes no dia 9 . . . . . . . . 193 Ilustração 126: Vestimenta de dormir dos ocupantes no dia $10 \ldots \ldots . \ldots 193$ Ilustração 127: Vestimenta de dormir dos ocupantes no dia $11 \ldots \ldots \ldots \ldots$ Ilustração 128: Ocupantes do primeiro dia de medições . . . . . . . . . . . 194 Ilustração 129: Ocupantes do segundo dia de medições . . . . . . . . . . . 194 Ilustração 130: Ocupantes do Terceiro dia de medições ... . . . . . . . . . . . 194 



\section{Lista de tabelas}

Tabela 1: Ocupação por motivo de viagem - Dados de 1997 (\%) . . . . . . . . 17

Tabela 2 Classificação de hotéis de acordo com tamanho do hotel ......... 20

Tabela 3: Classificação quanto ao "mercado" ........................ 21

Tabela 4: Classificação do Hotel segundo a área da UH $\ldots . . . . \ldots \ldots 45$

Tabela 5: Áreas das UH para as categorias de hotéis -Europeus e Americanos .45

Tabela 6: Áreas mínimas das UH cada categoria de Hotel $\ldots \ldots \ldots . \ldots 45$

Tabela 7: Estágios do projeto com potencial de integração de arquitetura bio-

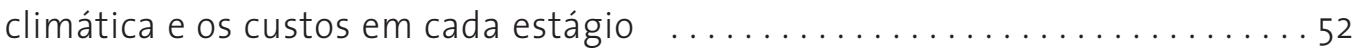

Tabela 8: Limites das zonas de conforto térmico da ISO $7730 \ldots \ldots 63$

Tabela 9: TBS máximo e mínimo no dia de referência de projeto de verão para São Paulo

Tabela 10: Limites de temperatura de conforto segundo o modelo adaptativo da ASHRAE $55(2004)$......................................... 107

Tabela 11: Porcentagem de horas mensais em conforto na face Norte - $\mathrm{N}$ (10 \% de insatisfeitos) . . . . . . . . . . . . . . . . . . . . . . . . . 112

Tabela 12: Porcentagem de horas mensais em conforto na face Sul - S

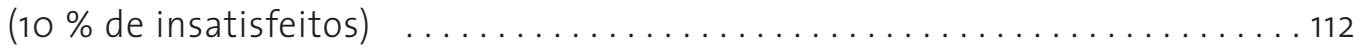

Tabela 13: Porcentagem de horas mensais em conforto na face Nordeste - NE (10 \% de insatisfeitos) ................................... 113 
Tabela 14: Porcentagem de horas mensais em conforto na face Sudoeste - SO

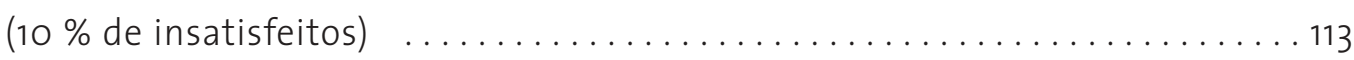

Tabela 15: Porcentagem de horas mensais em conforto na face Leste - E (10 \% de insatisfeitos) ................................... 114

Tabela 16: Porcentagem de horas mensais em conforto na face Oeste - O (10 \% de insatisfeitos) . .................................. 114

Tabela 17: Porcentagem de horas mensais em conforto na face Sudeste - SE

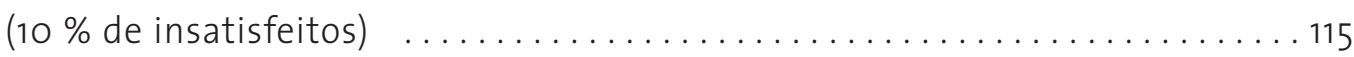

Tabela 18: Porcentagem de horas mensais em conforto na face Noroeste - NO (10 \% de insatisfeitos) .................................... 115

Tabela 19: Sistema de lluminação artificial da UH . . . . . . . . . . . . . 177

Tabela 20: Equipamentos existentes na UH ..................... 177

Tabela 21: Listagem dos materiais componentes internos dos apartamentos do Hotel analisado ...................................... 187

Tabela 22: Listagem dos componentes externos do Hotel . . . . . . . . . . . . 187

Tabela 23: Questionário para os "hóspedes de controle" ............. . . . 192

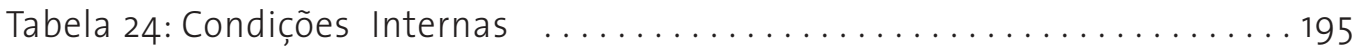

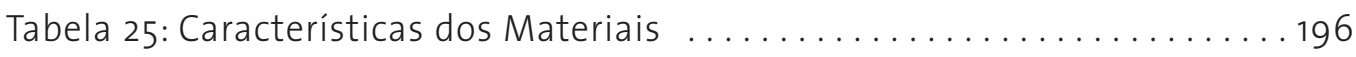

Tabela 26: Composição dos materiais . . . . . . . . . . . . . . . . . . . 197

Tabela 27: Programação de equipamentos e pessoas (schedules) . . . . . . 198 


\section{Lista de abreviaturas e siglas}

$\begin{array}{ll}\text { ABESCO } & \text { Associação Brasileira das Empresas de Serviços de Conservação de } \\ \text { ABIH } & \text { Energia } \\ \text { ABNT } & \text { Associação Brasileira da Indústria de Hotéis } \\ \text { AC } & \text { Associação de Normas técnicas } \\ \text { ANEL } & \text { Ar condicionado } \\ \text { ANVISA } & \text { Asência Nacional de Energiação Elétrica } \\ \text { APO } & \text { Avaliação Pós-Ocupal de Vigilância Sanitária } \\ \text { BANC } & \text { Bancada } \\ \text { BEN } & \text { Balanço Energético Nacional } \\ \text { Btu } & \text { British Thermal Unit } \\ \text { CCV } & \text { Custo do ciclo de vida } \\ \text { Clo } & \text { Resistência térmica da roupa (sigla do inglês) } \\ \text { CNTUR } & \text { Conselho Nacional de Turismo } \\ \text { COP } & \text { Coeficiente de desempenho (sigla do inglês) } \\ \text { CTC } & \text { Controle de temperatura do condensador (sigla do inglês) } \\ \text { EC } & \text { Resfriadores evaporativos para pré-resfriamento (sigla do inglês) } \\ \text { ECA } & \text { Escola de Comunicação e Artes } \\ \text { ELETROBRÁS } & \text { Centrais Elétricas Brasileiras S.A. } \\ \text { EMBRATUR } & \text { Empresa Brasileira de Turismo } \\ \text { EMP } & \text { Empírico } \\ \text { Env } & \text { Envoltória }\end{array}$




\begin{tabular}{|c|c|}
\hline EPUSP & Escola Politécnica Faculdade de Engenharia Civil \\
\hline $\mathrm{Et}^{*}$ & Temperatura Efetiva \\
\hline GBtool & Green Building Challenge \\
\hline HPC & Controle de pressão (sigla do inglês) \\
\hline IAG & Instituto de Astronomia, Geofísica e Ciências Atmosféricas \\
\hline IAT & Índice de Atividade Térmica \\
\hline IEA & International Energy Agency \\
\hline$I H \& R a$ & Associação de Restaurantes e dos Hotéis Internacionais \\
\hline INEE & Instituto Nacional de Eficiência Energética \\
\hline INMETRO & Instituto Nacional de Metrologia Normalização e \\
\hline & Qualidade Industrial \\
\hline IPCC & Intergovernmental Panel on Climate Change \\
\hline IPT & Instituto de Pesquisas Tecnológicas \\
\hline IPVL & Valor integrado de carga parcial (sigla do inglês) \\
\hline ISO & International Organization for Standardization \\
\hline LABAUT & Laboratório de Conforto Ambiental e Eficiência Energética \\
\hline LabEEE & Laboratório de Eficiência Energética em Edificações \\
\hline LED & Light Emitting Diode \\
\hline LEED & Leadership in Energy and Environmental Design \\
\hline LNEC & Laboratório Nacional de Engenharia Civil \\
\hline MM & Modo Misto \\
\hline $\mathrm{m} / \mathrm{s}$ & Metros por segundo \\
\hline Met & Metabolismo \\
\hline NBR & Norma Brasileira \\
\hline NE & Nordeste \\
\hline NO & Noroeste \\
\hline NV & Naturalmente ventilados \\
\hline${ }^{\circ} \mathrm{C}$ & Graus Celsius \\
\hline OECD & Organization for Economic Co-operation and Development \\
\hline OMT & Organização Mundial de Turismo \\
\hline ONG & Organização Não Governamental \\
\hline ONU & Organização das Nações Unidas \\
\hline p. & Página \\
\hline PIB & Produto Interno Bruto \\
\hline PMV & Predicted Mean Vote \\
\hline PPD & Predicted Percentual Dissatisfaction \\
\hline PPI & Porcentagem de Pessoas Insatisfeitas \\
\hline
\end{tabular}




\begin{tabular}{|c|c|}
\hline ppm & Partes por milhão \\
\hline PROCEL & Programa Nacional de Conservação de Energia Elétrica \\
\hline QDP & Quádruplo (sigla do inglês - quadruple) \\
\hline SAC & Sistema de Ar Condicionado \\
\hline SE & Sudeste \\
\hline SGA & Sistema de Gestão Ambiental \\
\hline SGL & Simples (sigla do inglês - single) \\
\hline SGQ & Sistema de Gestão da Qualidade \\
\hline SO & Sudoeste \\
\hline Str & Fator Solar \\
\hline ta & Temperatura do ar \\
\hline TAS & Thermal Analysis Simulation \\
\hline TBU & Temperatura de bulbo úmido \\
\hline TC & Temperatura de Conforto \\
\hline $\operatorname{tg}$ & Temperatura de globo \\
\hline TR & Tonelada de refrigeração \\
\hline $\operatorname{tr}$ & Temperatura média radiante \\
\hline TRL & Triplo (sigla do inglês - triple) \\
\hline TRM & Temperatura radiante média \\
\hline TWI & Duplo (sigla do inglês - twin) \\
\hline UFSC & Universidade Federal de Santa Catarina \\
\hline $\mathrm{UH}$ & Unidades habitacionais (apartamentos de hotéis) \\
\hline UNEP & União Nacional de Programas Ambientais (sigla do inglês) \\
\hline UR & Umidade relativa \\
\hline USP & Universidade de São Paulo \\
\hline va & Velocidade do ar em m/s. \\
\hline VME & Voto médio estimado \\
\hline VN & Ventilação natural \\
\hline VSF & $\begin{array}{l}\text { Velocidades variáveis dos ventiladores dos condensadores } \\
\text { (sigla do inglês) }\end{array}$ \\
\hline WTO & World Tourism Organization \\
\hline WTTC & Conselho mundial de viagens e turismo (sigla do inglês) \\
\hline WWR & Window wall ratio (sigla do inglês) \\
\hline
\end{tabular}





\section{Sumário}

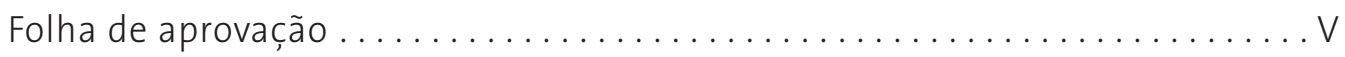

Dedicatória ....................................... VII

Agradecimentos ..................................... IX

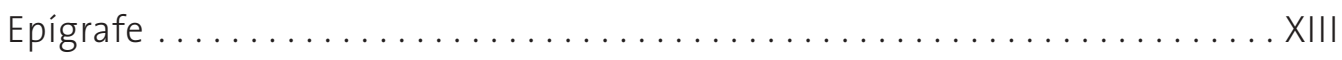

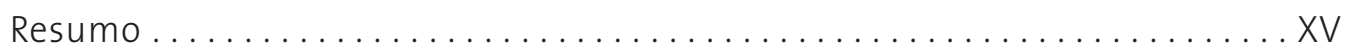

Abstract ...........................................

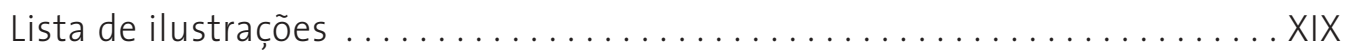

Lista de tabelas ................................... XXVII

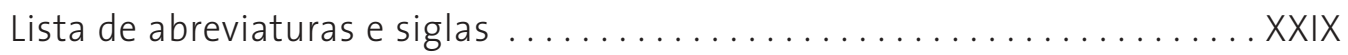

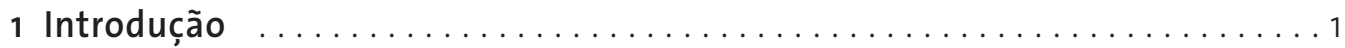

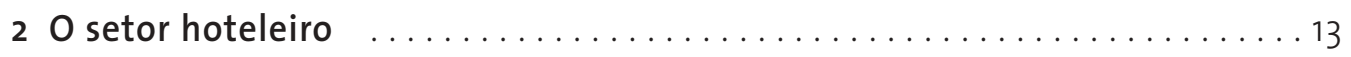

2.1 Aspectos históricos: O surgimento e a evolução dos hotéis . . . . . . . . . 14

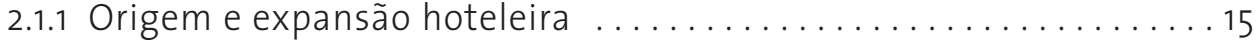

2.1.2 As redes hoteleiras no Brasil ..................... 15

2.2 Critérios de classificação dos Hotéis ......................... 16

2.2.1 O modelo da OMT .............................. 17

2.2.2 Redes internacionais ......................... 18

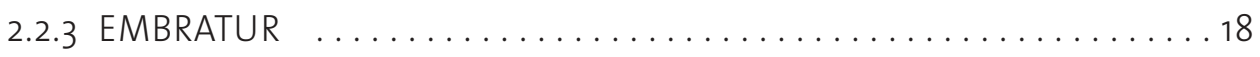

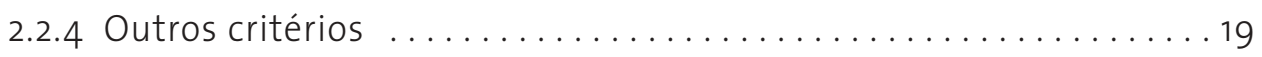

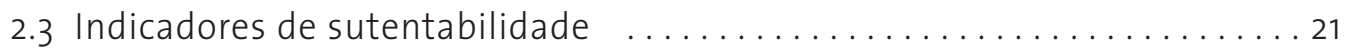


2.4 Estratégias de adaptação ao mercado . ....................... 24

2.4.1 Estratégias operacionais das redes internacionais ...........24

2.4 .2 O caso do Maksoud .............................. 26

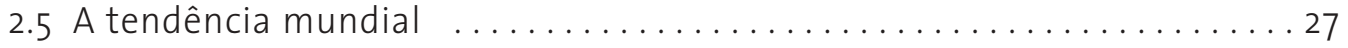

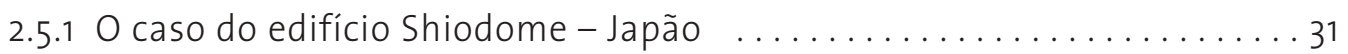

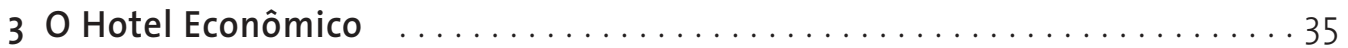

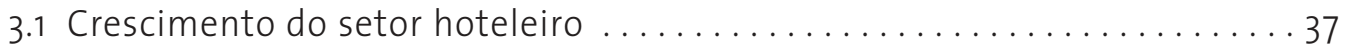

3.1.1 O projeto do empreendimento como estratégia de mercado . . . 4 40

3.2 O projeto do Hotel Econômico ....................... 41

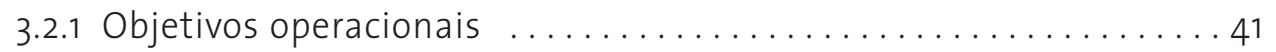

3.2.2 Dimensionamento dos espaços $\ldots \ldots \ldots \ldots \ldots \ldots \ldots \ldots \ldots 43$

3.2.3 Os sistemas de ar condicionado $(\mathrm{SAC}) \ldots \ldots \ldots \ldots \ldots \ldots \ldots 46$

3.2.4 Diferencial das redes $\ldots \ldots \ldots \ldots \ldots \ldots \ldots \ldots \ldots \ldots \ldots . \ldots 48$

3.2.5 Um exemplo de projeto de hotel econômico em São Paulo ... . 49

4 Um novo conceito de projeto de Hotel Econômico .................. 51

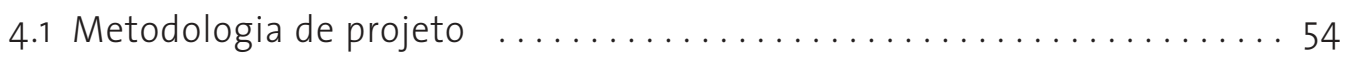

4.2 O programa arquitetônico de Hotéis Econômicos .................. 56

4.2.1 Análise do programa de necessidades, áreas e fluxograma . . ...56

4.2.2 Padrões de operação: uso e ocupação . . . . . . . . . . . . . 56

4.3 Diagnóstico climático ................................. 58

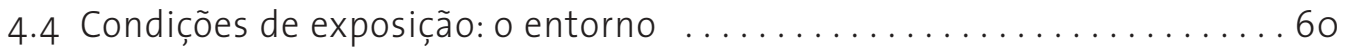

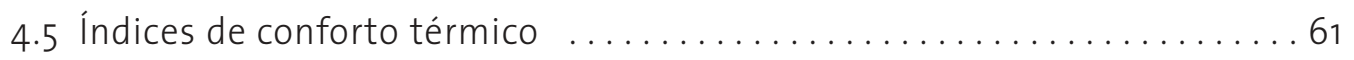

4.6 Opção pelo condicionamento natural ..................68

4.6 .1 Ventilação natural . . . . . . . . . . . . . . . . . . . . 69

4.6.2 Dispositivos de proteção solar . . . . . . . . . . . . . . . . 72

4.7 Opção pelo condicionamento artificial $\ldots \ldots \ldots \ldots \ldots \ldots \ldots \ldots \ldots \ldots$

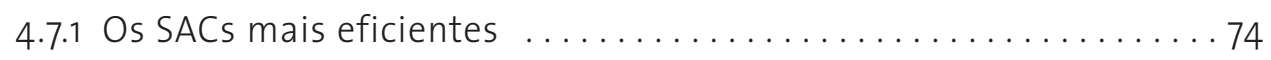

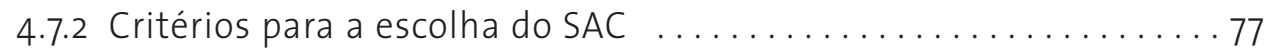

4.7.3 Dimensionamento da capacidade do SAC .............. 82

4.8 Opção pelo modo misto: natural + artificial $\ldots \ldots \ldots \ldots \ldots \ldots \ldots$

4.9 Aspectos complementares .......................... 91

4.9 .1 Iluminação . . . . . . . . . . . . . . . . . . . . . . . . 92

4.9 .2 Exposição ao ruído ................................ 95 
5 Análise paramétrica com base em estudo de caso $\ldots \ldots \ldots$

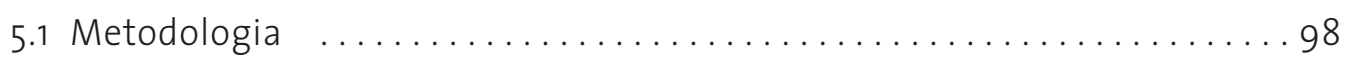

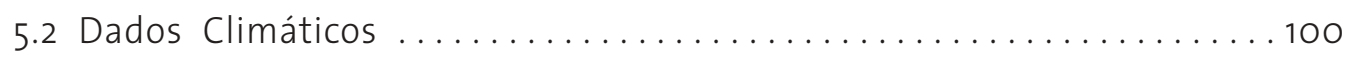

5.2.1 Tratamento dos dados climáticos para a $1^{\text {a }}$ etapa $\ldots . . . . . . .100$

5.2.2 Tratamento de dados para a escolha dos dias representativos

de inverno e verão ............................... 103

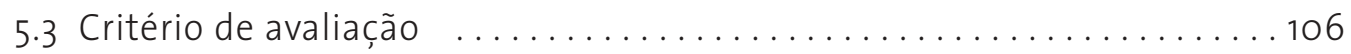

5.3 .1 Índice de conforto térmico ........................... 106

5.3.2 Opção de condicionamento para as simulações $\ldots \ldots \ldots \ldots \ldots 6$

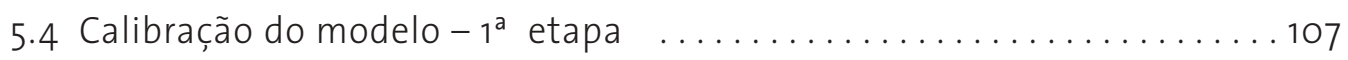

5.4.1 Balanço anual de oito orientações $-2^{\text {a }}$ etapa . . . . . . . . . . . . . 111

5.4 .2 Variação dos componentes $-3^{\text {a }}$ etapa $\ldots \ldots \ldots \ldots \ldots \ldots \ldots \ldots$

5.4 .3 Análise dos resultados ......................... 117

5.4 .4 Variação de componente opaco $-4^{\text {a }}$ etapa $\ldots \ldots \ldots \ldots \ldots \ldots 125$

6 Propostas de projeto para Hotel Econômico em São Paulo ... . . . . . . . 129

6.1 P remissas para o projeto .............................. 130

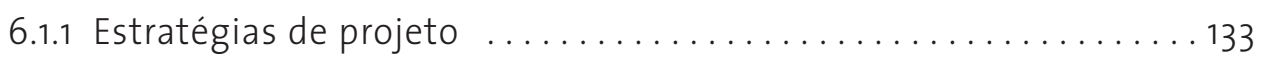

6.2 Avaliação dos arranjos do pavimento tipo . . . . . . . . . . . . . . 135

6.3 Estudos das fachadas ............................... 137

6.4 Propostas para a unidade habitacional ................... 138

6.4.1 Detalhes arquitetônicos ............................... 141

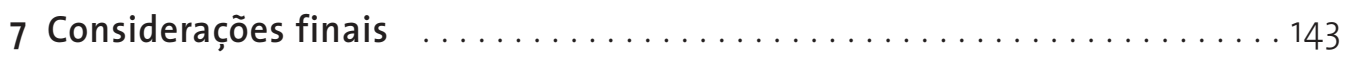

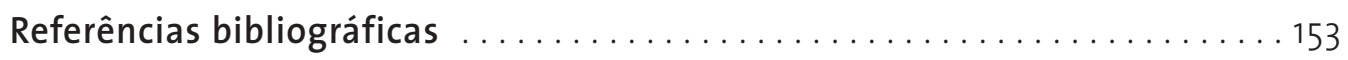

Apêndice A: Levantamento de dados Empíricos - Estudo de Caso . . . . . . . 167

Apêndice B: Questionário para o "hóspede de controle" ............... 191

Apêndice C: Características da ocupação . . . . . . . . . . . . . . . 193

Apêndice D: Dados de entrada utilizados nas simulações computacionais . . 195 



\section{Introdução}

As intensas discussões em nível internacional acerca do aquecimento global, que culminaram no protocolo de Kioto, em dezembro de 1997, intensificaramse nos últimos dois anos. A preocupação com o consumo e a geração de energia, um dos principais itens dessas discussões, estão na ordem do dia da agenda de negociações internacionais. O Brasil, segundo estudos realizados em 2003 (DELBIN e SILVA, 2005), tem um consumo de energia que representa $2,1 \%$ do consumo mundial.

A matriz energética brasileira, desde a década de 1920, já era $80 \%$ baseada na hidroeletricidade (ELETROBRÁS, 2007). Seguindo a tendência mundial, nas décadas de 40 e 50 as usinas passaram a ser cada vez maiores, a fim de reduzir os custos na instalação e geração de energia. Entretanto, com a intensificação da industrialização ocorrida ao longo do século XX a aglomeração dos grandes centros urbanos e a localização das principais hidroelétricas, distantes dos maiores mercados consumidores de energia e por esse motivo exigindo linhas de transmissão com grandes perdas de carga energética, aprofundou-se a preocupação com a quantidade de energia ainda disponível. Isso ocorreu especialmente a partir dos anos 70, vindo a culminar com a lei $n^{0} 5899$ de 1973, que atribuiu à Eletrobrás a competência para promover a construção e a operação de sistemas de transmissão em alta tensão, visando a integração interestadual dos sistemas e o transporte de energia elétrica de Itaipu.

Foi nesse contexto que se tornou possivel a exploração do potencial hidroelétrico existente em Itaipu, em funcionamento desde 1987. Em 1997, Itaipu respon- 
dia por $26 \%$ da energia que movimentava a economia brasileira. Atualmente ela gera aproximadamente $25 \%$ desse mesmo total (ELETROBRÁS, 2007).

As usinas com reservatórios de acumulação geram a energia a partir da água acumulada em grandes reservatórios, os quais permitem o acúmulo de água em quantidade suficiente para que a geração de energia elétrica esteja praticamente garantida, mesmo que chova pouca quantidade em determinado ano. Apesar disso, a sucessiva estiagem nos anos de 1999, 2000 e $2001 \mathrm{fez}$ com que Itaipu a mpliasse sua geração de energia para níveis acima de sua disponibilidade usual, a fim de compensar a queda de produção de outras hidrelétricas por falta de água. No entanto, Itaipu não foi capaz de atender à exigência do mercado do sudeste brasileiro, devido às limitações nas linhas de transmissão, agravando assim a crise energética brasileira em 2001, conhecida pelo público como "apagão".

Em países em desenvolvimento, como o Brasil, o crescimento do consumo de energia elétrica é uma constante, cerca de 3 a $5 \%$ ao ano, mesmo em períodos com estagnação econômica (ELETROBRAS, 2007). Isso não ocorre nos países desenvolvidos, com a base da economia em produtos de tecnologia industrializada. Nesses países, o consumo de energia elétrica está diretamente relacionado à produção e ao crescimento do Produto Interno Bruto (PIB).

$\mathrm{Na}$ Europa, o setor de edifícios representa o maior potencial unitário de eficiência energética, totalizando mais de um quinto do consumo atual de energia e representando o equivalente a 45 milhões de toneladas de $\mathrm{CO}_{2}$ por ano, o que, segundo UNEP (2007) pode, até 2010, ser economizado com o uso de normas mais ambiciosas para edifícios existentes e novos.

Nos últimos 80 anos, segundo Balcomb (1998), os edifícios no Brasil foram planejados sem preocupação com a eficiência energética. Santos e Martins (2002) concluíram que, em 2001, o consumo mundial de energia elétrica no setor de edificações correspondia a $40 \%$ da demanda, sendo uma parte utilizada no beneficiamento e na produção de materiais, e outra parte na ocupação e operação dos edifícios, incluindo aqui os sistemas de iluminação e de ar-condicionado. Dentre todos os diversos grupos de consumidores de energia no Brasil, o setor de edifícios (subdividido em comercial, residencial e público) representa $20 \%$ do consumo total.

Entretanto o consumo no setor de edificações não é linearmente distribuído durante seu ciclo de vida. Como podemos verificar na IL. 1, o ciclo de vida dos edifícios modernos consome energia em quatro fases seqüenciais: na fabricação dos materiais ( $1^{\text {a }}$ fase), no transporte e produção ( $2^{\text {a }}$ fase), na construção e na ope-

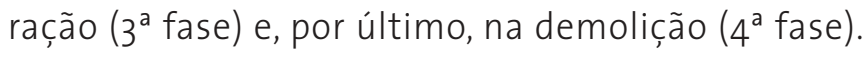




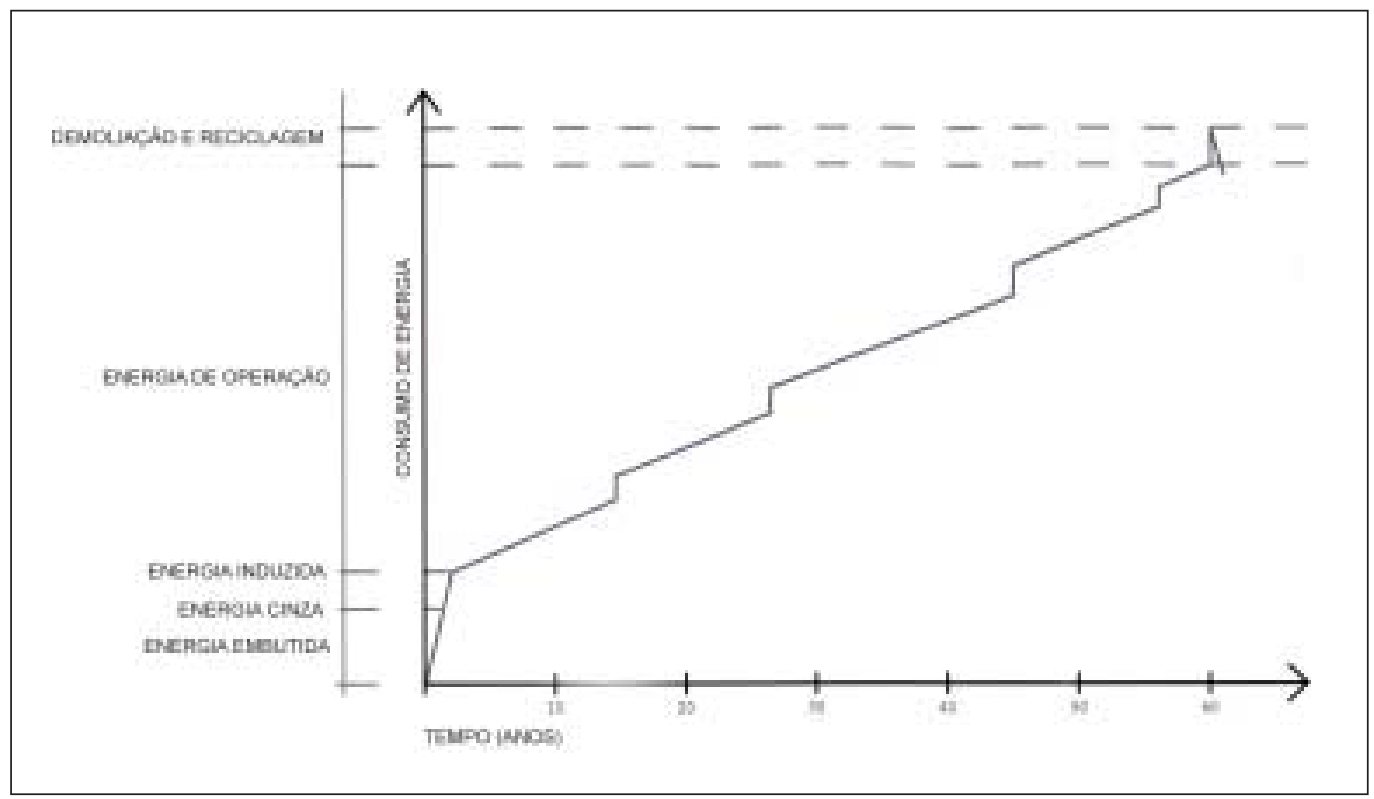

Ilustração 1: Energia consumida no ciclo de vida de um edifício. Fonte: JONES, 1998.

Do total da energia consumida pelo setor, $42 \%$ é proveniente do consumo de energia elétrica. Na vida útil dos edifícios-padrão, estima-se que cerca de $80 \%$ da energia seja consumida no ciclo de uso: no resfriamento, aquecimento, iluminação, cozinha, ventilação e assim por diante (UNEP, 2007).

Em relatório recente do Balanço Energético Nacional (BEN) sobre o mercado de eficiência energética do Brasil, Correia (2007) verificou que, durante o período do racionamento (entre os anos de 2001 e 2002), 61\% das empresas adotaram medidas de gerenciamento energético, seguidas por medidas de eficiência energética, em $31 \%$ das empresas. A somatória dessas duas modalidades de medidas gerou efeitos diretos no setor dos edifícios, especialmente na concepção e manutenção dos mesmos.

Outros estudos revelaram que, para edifícios com usos específicos, como comercial e hoteleiro, é possivel reduzir o consumo de energia pela metade, se os projetos dos edifícios forem energeticamente eficientes, exigindo menor uso de alternativas ativas para a obtenção de conforto.

Segundo Kronka (2002), o Brasil não possuía nenhum instrumento legal de controle de desempenho termo-energético das edificações até 2001. No entanto, essa situação mudou depois do decreto NO 4.059 de 19 de dezembro de 2001, quando foi elaborada a Regulamentação para Etiquetagem Voluntária de Nivel de Eficiência Energética de Edifícios Comerciais, de Serviços e Públicos, aprovada em 2006. 
O Ministério de Minas e Energia e a Eletrobrás, no âmbito do Programa Nacional de Conservação de Energia Elétrica (PROCEL), o chamado Edifica, buscaram, com essa regulamentação ainda que voluntária, estabelecer diretrizes para a eficiência e potência instalada do sistema de iluminação, a eficiência do sistema de ar condicionado (SAC), além do desempenho térmico da envoltória.

No entanto, como ainda não existem leis no Brasil que exijam o cumprimento de metas de eficiência energética para edifícios, o caminho a ser trilhado no sentido de uma maior eficiência no consumo de energia passa pela conscientização dos proprietários, incorporadores, construtores e arquitetos, entre outros, sobre a utilização de novas tecnologias na adequação climática.

\section{Relevância Do Setor Hoteleiro}

O edifício hoteleiro tem, como peculiaridade, o fato de funcionar ininterruptamente e de ser um ambiente de grande complexidade, dada a diversidade e quantidade de funções exercidas junto ao conjunto de atividades complementares que acontecem em suas dependências. O maior exemplo de desenvolvimento turístico refere-se ao edifício hoteleiro mais comentado da atualidade: o Hotel Burj Al Arab, situado na capital do Emirado de Dubai, localizado na região do Oriente Médio mais conhecida como Emirados Árabes (IL. 2).

Sua arquitetura arrojada, com formato externo de um veleiro que parece flutuar sobre uma das milhares de ilhas artificiais da cidade, contrasta com a decoração interior, o luxo dos materiais de decoração, de origens, cores e padrões típicos da região (com folhas de ouro e infinitos detalhes característicos da arquitetura árabe). Esse hotel tornou-se um dos pontos turísticos mais famosos do mundo, a ponto de situar Dubai na rota mundial do turismo. O mesmo hotel é ainda referência de arquitetura e de serviços para o padrão hoteleiro de seis estrelas, resultando em diárias exorbitantes (cerca de nove mil dólares).

A função hospedagem pressupõe apartamentos adequados, dotados de conforto ambiental/térmico, acústico, luminoso e ergonômico, espaços bem dimensionados, devidamente equipados e com ambientes agradáveis. Deve igualmente contar com atividades administrativas, centrais de sistemas prediais, de manutenção, além daquelas relacionadas com a realização de eventos, recreação e lazer.

Tal complexidade funcional demanda um mínimo de investimentos para tornar o empreendimento hoteleiro economicamente viável, o que resulta num empreendimento oneroso e muito sensivel aos custos finais de construção, operação e manutenção (ANDRADE et. al, 2003). No Brasil, foi o aumento da demanda por viagens e hospedagem, deflagrado a partir da década de 80, que acirrou a 


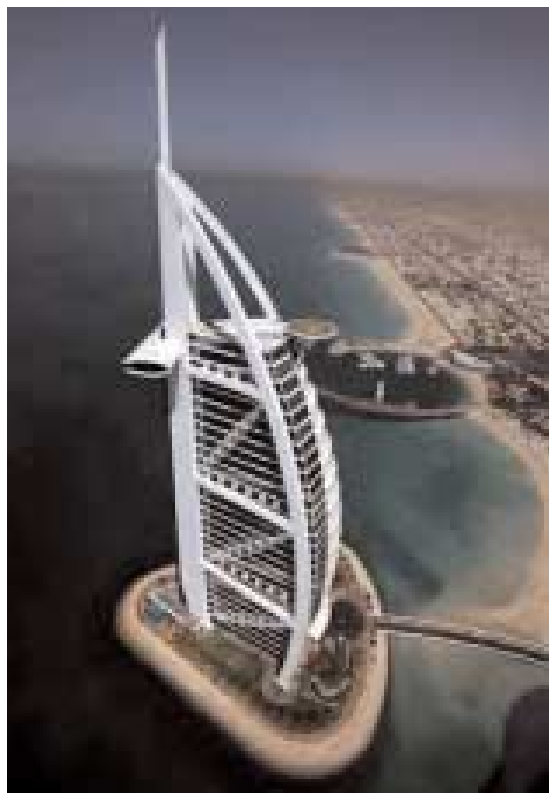

Ilustração 2: Hotel Burj Al Arab em Dubai. Fonte: ATLASSHRUGS, 2000.

competição no setor, determinando assim a necessidade de ampliar as escalas de operação, baratear custos e diversificar locais de atuação e recepção de um número cada vez mais amplo de viajantes que passaram a se deslocar em ritmo mais intenso e com mais freqüência.

Além dessa ampliação do mercado de viagens e da incorporação de novos segmentos de menor poder aquisitivo, houve também um grande crescimento no setor de eventos (SPOLON, 2006), o qual repercutiu no aumento da participação das novas redes hoteleiras no mercado, ameaçando assim a hotelaria instalada (LIMA, 2003). Esse avanço ocorreu principalmente nos grandes centros econômicos, tais como São Paulo e Rio de Janeiro

As estratégias competitivas das redes internacionais, com marcas fortes, programas de treinamentos com padrões internacionais, centrais de reservas e capital disponível a juros baixos garantiram a entrada, no mercado brasileiro, de várias redes econômicas internacionais. Uma das características das marcas econômicas é o valor das diárias baixas, resultado da otimização das instalações e da redução de serviços ao mínimo essencial para o hóspede a que se destinam, sem prejudicar a qualidade exigida por ele. Conforme salientou Lindzmayer (2002), as instalações hoteleiras devem oferecer o máximo de conforto e atender as expectativas dos hóspedes exigentes, com especial atenção aos inúmeros detalhes construtivos e operacionais, "para que a configuração física traduza cabalmente a intenção de bem servir". 


\section{Sobre Conforto Térmico}

Dentre os itens de conforto a serem atendidos, o conforto térmico tem especial relevância e implicações para nosso estudo. O conceito de conforto térmico, por sua vez, é bastante relativo e subjetivo. De acordo com a norma ASHRAE 55 (2004), conforto térmico para uma pessoa pode ser definido como a "satisfação com o ambiente térmico onde ela se encontra", o que significa que a pessoa em questão não prefere necessariamente um ambiente mais frio ou mais quente (FANGER, 1973).

O conceito de conforto procura, pois, atender às exigências humanas e funcionais, trabalhando na convergência de estímulos físicos propiciados pelo meio ambiente, da construção e do usuário.

Escrevendo sobre a regulação comportamental, Humphreys (1995) ressaltou que as pessoas tendem, naturalmente, a procurar por condições de conforto, Sol e sombra, vento ou proteção, assim como procuram ajustar sua postura, atividade e roupas, a fim de obterem conforto. O conforto térmico é facilitado quando o meio ambiente térmico é previsível, sem exigir dos usuários uma adaptação de roupas e nem a preocupação com o posicionamento e acionamento das aberturas que podem ocasionar ventos imprevisíveis e indesejados, exigindo alguma atitude do usuário para controlá-la.

Neste sentido, o desempenho durante qualquer atividade física ou mental pode ser otimizado, desde que o ambiente propicie condições de conforto, sendo esse o primeiro objetivo dos sistemas de controle ambiental (JABARDO, 1984).

Para que esses sistemas sejam otimizados, é fundamental o conhecimento do local onde está inserida a edificação. Destaca-se aqui a importância de realizar diagnósticos seguros para a realidade brasileira - tipo de edifício, posição geográfica, problemática tecnológica e de utilização-, levando-se em conta as disponibilidades e os custos (MASCARÓ, J.e MASCARÓ, L, 1992).

No ultimo relatório do Balanço Energético Nacional (BEN) sobre a eficiência energética no Brasil, foram avaliados os setores comercial, residencial e industrial (CORREIA, 2007). Ali foram colhidas amostras de 2700 empresas, sendo 100 unidades por cada concessionária de energia, com um erro estimado de 3,1\%.

Dentro do setor comercial dos hotéis avaliados, verificou-se que o consumo médio para cada unidade habitacional (UH) foi de $464 \mathrm{kWh} / \mathrm{mês}$. No mesmo estudo, verificou-se que, no setor comercial em geral, o SAC representa $47 \%$ do consumo, conforme indicado na IL. 3 . 


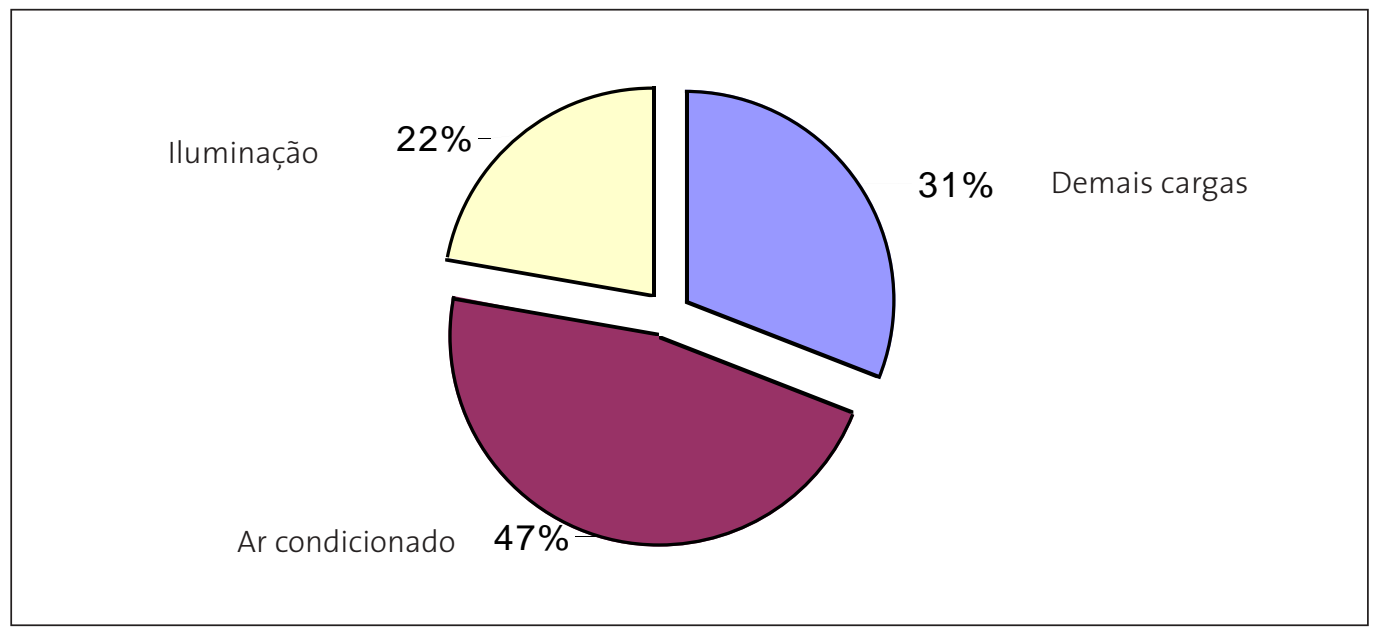

Ilustração 3: Distribuição do consumo por uso final - Setor Comercial.

Fonte: CORREIA, 2007.

Quando existe a integração, em um projeto de edifício, do uso de ar condicionado, sistemas ativos ${ }^{1}$ com o uso de sistemas passivos ${ }^{2}$ - o chamado modo misto (MM) -, o projeto deve ser feito adequadamente, para obter a melhor combinação entre os dois sistemas, o ativo e o passivo. Nestes casos, as condições climáticas são determinantes para a definição das estratégias de projeto mais adequadas, como a ventilação natural (VN), por exemplo. A operação de um edifício em modo misto, na cidade de São Paulo, possui um potencial de eficiência energética elevado (De BENEDETTO, 2007), já que, desta forma, o potencial dos sistemas passivos pode ser explorado com a finalidade de reduzir o consumo de energia elétrica pelo sistema de ar condicionado.

O European Common Research Center (1996) destacou, em publicação sobre ventilação, qualidade do ar e impacto no ser humano que, diante das condições climáticas locais, a ventilação natural pode ser utilizada de forma parcial ou permanente em diversos tipos de edifícios. Na mesma linha de pesquisa, diversos autores (ANDRADE, 2005; LAMBERTS, DUTRA, PEREIRA, 1997; ROMERO,1997) salientam que o principal objetivo de qualquer sistema de ventilação é prover boa qualidade interna de ar e assim satisfazer os usuários.

Em ambientes internos, quanto mais apropriadas as estratégias de ventilação, maior a economia de energia e melhor a qualidade do ar. Melhorar a qualida-

1. Sistemas ativos, ou artificiais: também denominados sistemas ativos de condicionamento ambiental, são sistemas que fazem uso de estratégias artificiais de climatização e iluminação no ambiente construído.

2. Sistemas passivos, ou naturais: também denominados sistemas passivos de condicionamento ambiental, são sistemas que fazem uso de estratégias de aquecimento ou resfriamento naturais e de iluminação natural no ambiente construído, sem consumir energia elétrica. 
de do ar nas edificações é provavelmente um dos melhores investimentos pois, do ponto de vista de Santamouris et. al (2002), esse fator melhora o desempenho dos seus ocupantes e sua produtividade no ambiente, constitui-se portanto numa exigência para o desempenho térmico dos edifícios.

O uso de estratégias que incorporem o comportamento do sistema passivo pode reduzir os ganhos de calor com um baixo investimento (FIORELLI, et. al, 2003), desse modo melhorando o conforto dos usuários. Torcellini, Pless e Judkoff (2007) destacam ainda que as estratégias de eficiência energética tornaram-se a maneira mais eficiente de reduzir o consumo total de energia em edifícios.

A integração das diversas tecnologias passivas nos edifícios requer soluções igualmente integradas de otimização, a fim de prover conforto e ao mesmo tempo reduzir substancialmente o impacto energético dos edifícios.

Na recente publicação da ASHRAE (TORCELLINI, PLESS, JUDKOFF, 2007), recebeu destaque o uso de tecnologias solares que, corretamente dimensionadas, servem como meio para a redução da geração de calor proveniente da iluminação (os chamados ganhos de calor) e conseqüentemente de redução da carga de resfriamento.

A maior fonte de preocupação do setor hoteleiro tem sido o crescente aumento dos custos operacionais das instalações prediais, além dos problemas de degradação e envelhecimento, devidos à escassez de investimentos. Decorre disso a importância da utilização de sistemas prediais adequados, que não demandem manutenção constante nem consumam grande quantidade de energia, como acontece com os equipamentos de ar-condicionado.

Dessa maneira, o projeto e a construção de um hotel constituem sempre uma atividade complexa, cabendo aos arquitetos e engenheiros interpretar as aspirações de seu grupo freqüentador: empresários, funcionários e hóspedes, a fim de estabelecer diretrizes para suas atitudes, visando sempre o bem-estar e a eficiência dos sistemas adotados para o bom funcionamento do edifício.

$\mathrm{Na}$ classificação nacional dos hotéis, segundo a Deliberação Normativa Nº 433 (EMBRATUR, 2002), os hotéis econômicos não são obrigados a possuir sistemas de ar condicionado nos apartamentos. Esses equipamentos podem constituir o equivalente a $47 \%$ do consumo de energia total do hotel (CORREIA, 2007). No entanto, as redes internacionais seguem os padrões internacionais, de que faz parte a oferta de ar condicionado nos apartamentos.

O clima de São Paulo propicia o uso de estratégias passivas na maior parte do ano (ALUCCI, 2005). Durante o período noturno de ocupação (BUORO, et. al, 2003, e MESQUITA, 2006), das 20:00 às 7:30 horas, quando os hóspedes ficam nos 
apartamentos, em $60 \%$ do ano recomenda-se o uso da ventilação como estratégia e, no restante do ano, nos meses mais frios (de maio a julho), a recomendação seria de uso da estratégia de massa térmica para aquecimento. Quanto menor o ganho de calor pelas envoltórias durante o dia nos apartamentos, na maior parte do ano (os 60\% acima mencionados), menor a chance dos hóspedes, ao chegarem no quarto, acionarem o ar-condicionado. Com isso, menor será também o consumo de energia do empreendimento.

A implementação de medidas que levem a um projeto de ar condicionado energeticamente otimizado ou à otimização das instalações existentes é um importante fator de redução de custos operacionais, atendimento de demandas ecológicas e prevenção de prejuízos econômico sociais advindos de um possível colapso no fornecimento de energia (FIORELLI et. al, 2001).

No entanto, conforme salientou Saiz Jabardo (2003), a disponibilidade de equipamentos e componentes de alta eficiência não assegura uma operação eficiente da instalação. É necessário que a manutenção e a operação estejam à altura da qualidade e do avanço tecnológico do produto.

Em linhas gerais, pode-se afirmar que os hotéis econômicos das redes internacionais configuram uma tipologia ainda mais desafiadora, quanto às exigências de conforto dos usuários atribuídas aos edifícios padronizados, aos avanços tecnológicos, à eficiência energética e aos sistemas de condicionamento artificiais, enquadrando-se nos propósitos desta pesquisa.

O objeto de estudo desta dissertação é a qualidade ambiental e a eficiência energética dos Hotéis Econômicos localizados em São Paulo, tendo como referência inicial a categoria de hotel econômico de uma rede hoteleira internacional. A referida rede possui a maior representatividade, tanto em número de apartamentos da categoria quanto no percentual de domínio de mercado nacional.

O foco principal deste estudo são os apartamentos dos referidos hotéis, nos quais o espaço físico deve ser agradável, com qualidade ambiental e alta eficiência energética, e sua interação com a forma e as características arquitetônicas. Trata-se de um ambiente no qual o uso de sistemas de condicionamento artificial de ar é comum, porém onde nem sempre o hóspede pode optar pelo não uso desse equipamento, principalmente quando se trata de edifícios com janelas lacradas.

O objetivo da dissertação é propor recomendações de projeto para esse padrão de hotel em particular, as quais poderão ser extrapoladas para outros hotéis e categorias, considerando-se a qualidade arquitetônica, o conforto térmico e a eficiência energética como as diretrizes para o projeto adequado. 


\section{Metodologia da pesquisa}

A estrutura deste trabalho segue o diagrama apresentado na IL. 4.

De início, a pesquisa adotou um embasamento teórico cujo objetivo foi de mapear as redes dos hotéis localizadas em São Paulo, oferecendo um panorama geral do setor hoteleiro. Em seguida, foram levantados os critérios de classificação dos hotéis no mundo e no Brasil, buscando assim situar o segmento hoteleiro estudado e justificar a escolha dos hotéis de categoria econômica de uma rede internacional, instalada na cidade de São Paulo.

Na segunda etapa deste trabalho, foi estudada a padronização dos projetos nesse setor e os reflexos que esta acarreta no consumo energético do hotel.

Em seguida foram investigadas as características de um hotel padronizado, de uma rede internacional de Hotéis, qual ambiente climatizado é mais representativo para avaliação do conforto e eficiência energética, suas características, determinando-se assim uma referência da dimensão e das propriedades da envoltória. Foram também determinados o perfil de ocupação do hotel e outras fontes de ganhos de calor como os equipamentos (exceto o ar-condicionado) e a iluminação, elementos fundamentais para a base de dados de entrada na etapa da simulação.

Como critério para avaliação do conforto térmico, o índice de conforto considerado é resultado da análise e adequação das normas nacionais e internacionais existentes (ABNT, ASHRAE e ISO), relacionadas ao conforto higrotérmico e adequadas às características do uso e da ocupação do ambiente em questão. Nesse sentido, adotou-se como critério o modelo adaptativo da ASHRAE 55/2004, que considera fatores como tempo, forma e função da edificação, relação entre o clima interno e externo, expectativas dos usuários, além do meio físico, para prever a satisfação dos usuários (De DEAR, BRAEGER e COPPER, 1997).

Foram, então, levantados os sistemas de ar-condicionado mais utilizados nesse setor e suas principais características, tais como capacidade refrigeradora, potência instalada, curva de rendimento, facilidade de instalação, facilidade de manutenção, renovação do ar, possibilidade de controle dos equipamentos, distribuição do ar no ambiente e custo do sistema.

Para embasar os critérios que foram avaliados nas simulações, foi realizado um ciclo de medição de temperatura e umidade relativa do ar (interna e externa) no contexto de um estudo de caso (Apêndice A) com uma ocupação controlada (usuários, vestimenta, período de uso de televisão e luzes acesas). Para essa etapa, foi desenvolvido um questionário destinado ao "hóspede de controle" (Apêndice B), levando-se em conta o padrão típico de ocupação dos hotéis da categoria (Apêndice C). 


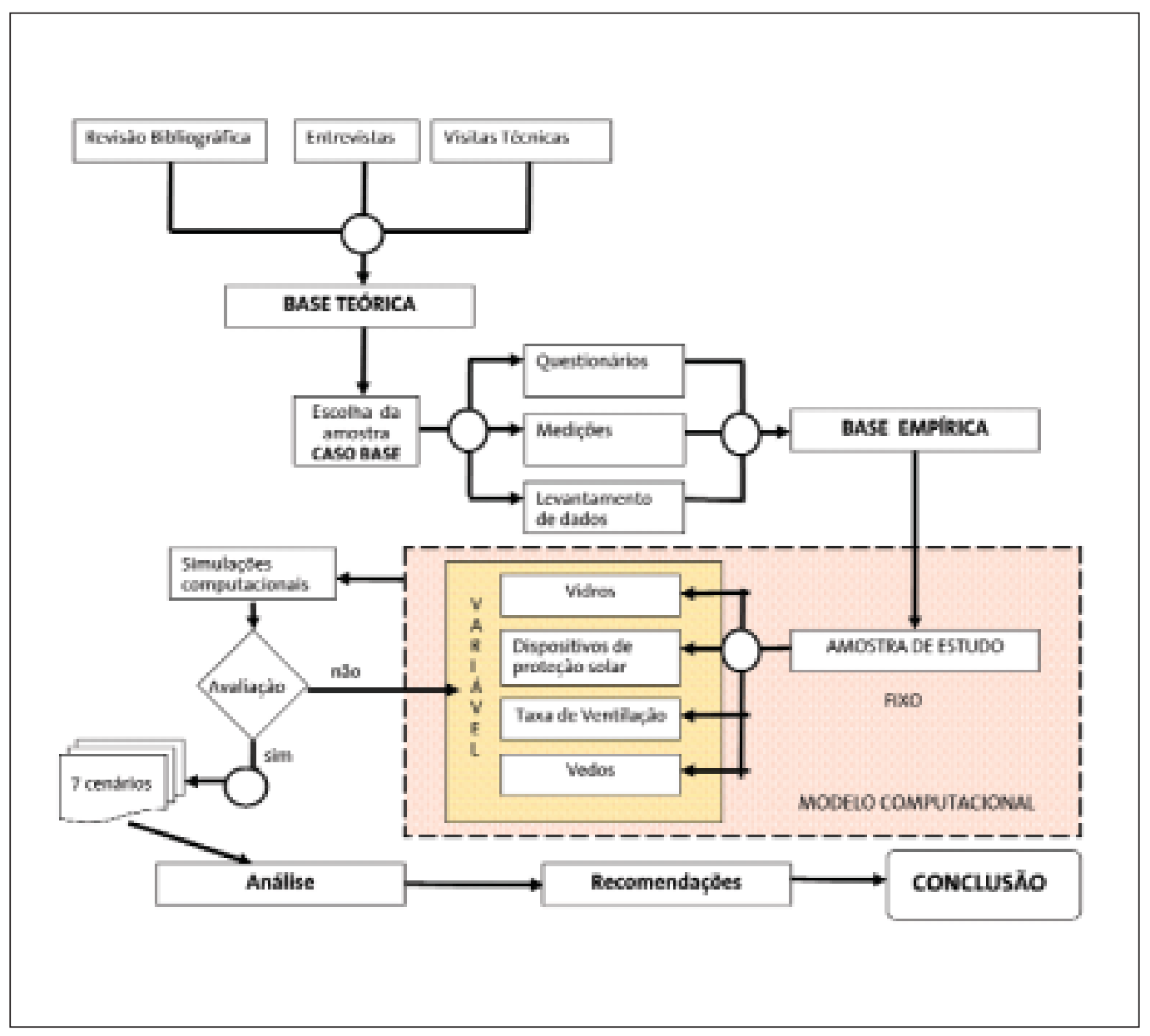

Ilustração 4: Diagrama da estrutura da dissertação.

Por meio da simulação, foi possível avaliar a demanda e o consumo anual do sistema de climatização, sendo que os dados de geometria, materiais e o perfil de ocupação do edifício foram definidos anteriormente. O software utilizado nas simulações termo-dinânimcas foi o TAS, Thermal Analisys Simulation (TAS NG, 2005) e a seqüência de simulação segue a IL. 5.

Após a análise dos resultados da simulação, foram identificadas as conclusões sobre conforto higrotérmico e a eficiência energética nos hotéis econômicos das redes internacionais localizados em São Paulo e, como resultado final, foram definidas as recomendações de projeto para os apartamentos de hotel, levandose em conta sua interface com a eficiência dos equipamentos de ar-condicionado.

Na última etapa deste trabalho, foi desenvolvido um estudo para nova proposição desta tipologia, com a apresentação de estudos preliminares, tanto da UH quanto da planta tipo, e da distribuição dos apartamentos numa forma de edifício mais eficiente, considerando os quesitos apresentados anteriormente. 


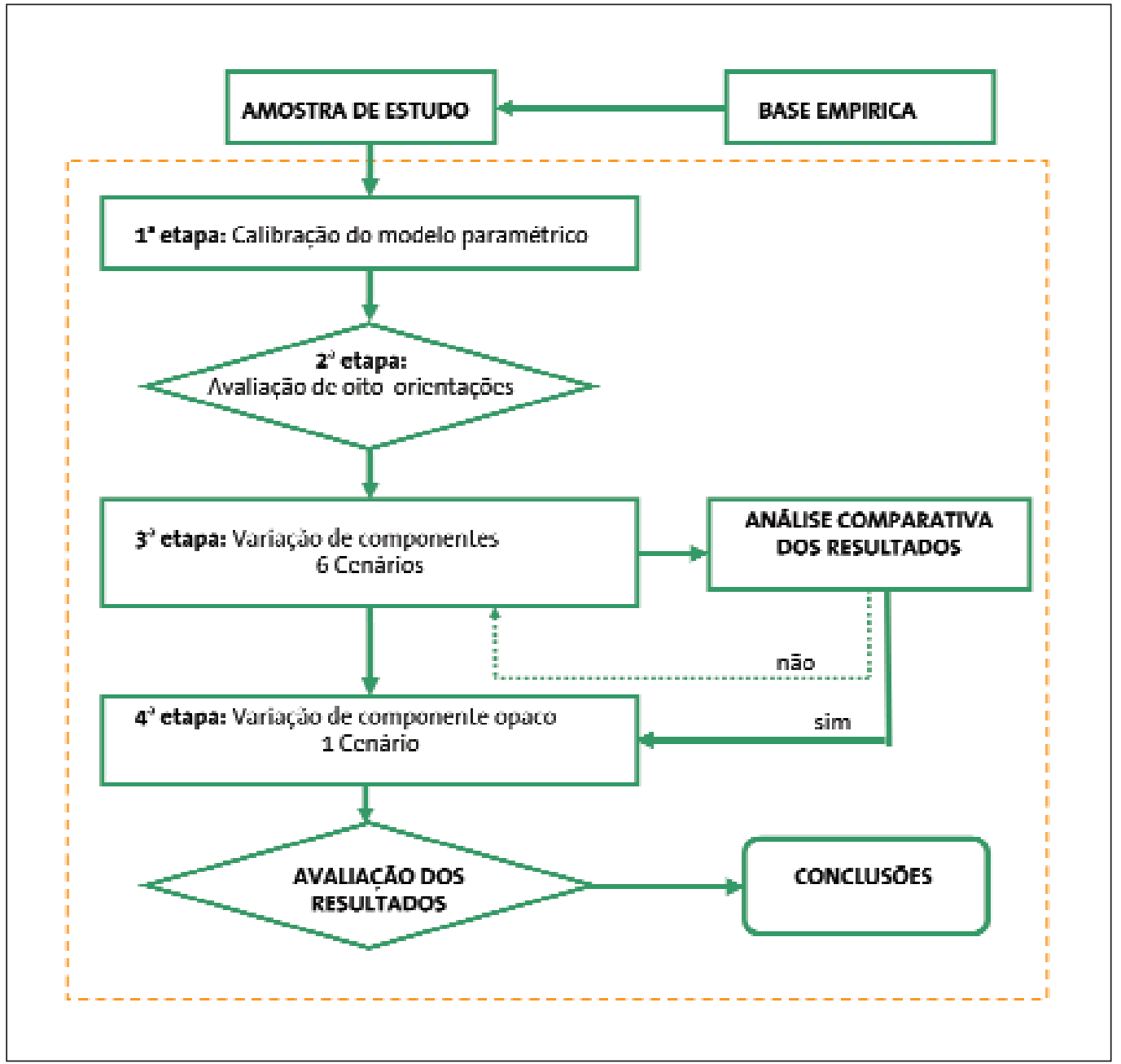

Ilustração 5: Seqüência das variáveis na etapa da avaliação paramétrica. 


\section{O setor hoteleiro}

Do ponto de vista arquitetônico, os hotéis são edificações de características especiais, seja pela repetição das unidades habitacionais (UH), seja pela grandiosidade dos espaços com função de reunir grande número de pessoas, ou mesmo pela complexidade de interações que eles comportam. Do ponto de vista econômico-financeiro, quanto mais rápido for o retorno do capital inicial investido, maior será o sucesso do empreendimento.

Para competir no mercado, todos os empreendimentos devem oferecer um diferencial. No caso dos hotéis, este diferencial pode levar em conta as considerações do arquiteto carioca Paulo Casé:

O hotel representa a concretização das fantasias do hóspede, o lado espetáculo da vida (...). Temos que pensar que o hóspede é extremamente exigente, e que não admite em um hotel o que, por vezes, admitiria em sua casa; daí a importância da atenção dada a todas as insignificâncias, para que tudo contribua para realçar aquela fantasia inicial do hóspede (CADERNO BRASILEIRO DE ARQUUITETURA, 1997)

Uma UH do Hotel de Gelo construído anualmente no período de inverno a $200 \mathrm{~km}$ do circulo Ártico, apresentado na IL. 6, exemplifica o quanto a fantasia do hóspede pode também estar relacionada à curiosidade e a inovação do referido Hotel.

Este Hotel é anualmente reconstruído, já que naturalmente ele derrete no verão. Todo em gelo constituí-se numa edificação de beleza única e irrepetível, a 


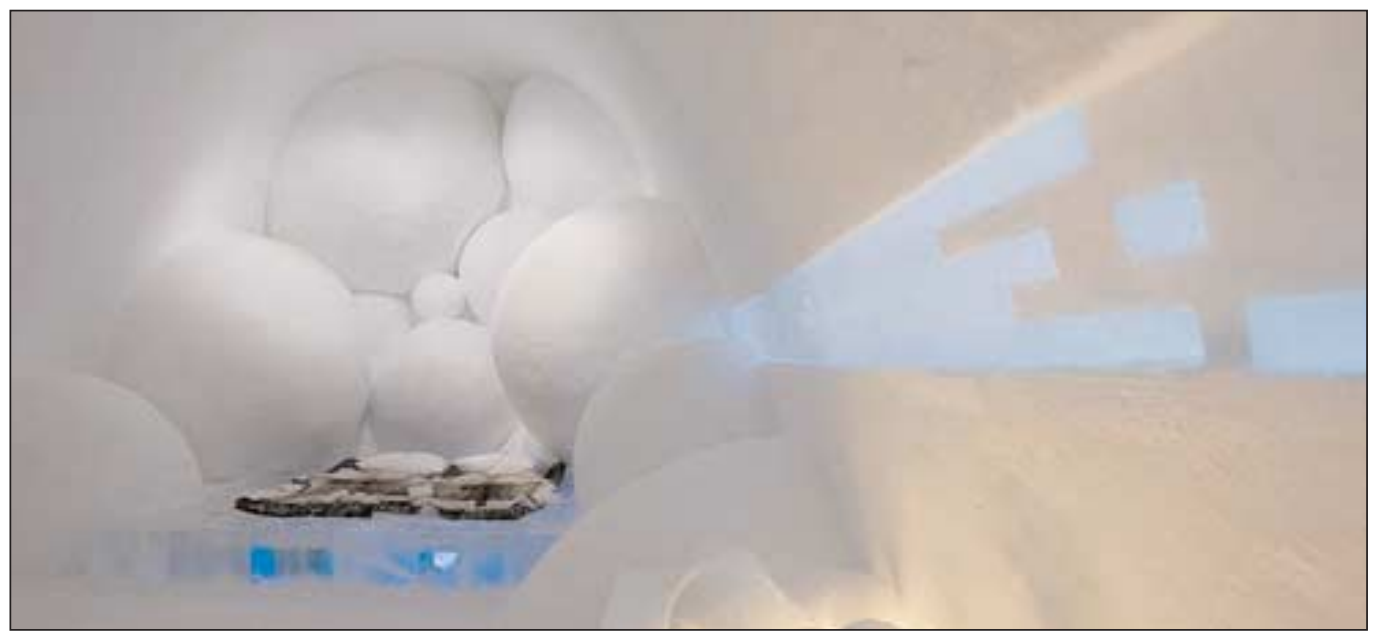

Ilustração 6: Apartamento do Hotel de gelo onde o hóspede dorme em UH com a temperatura do ar estimada em menos cinco graus Celsius Fonte: ICEHOTEL, 2007.

qual atrai pessoas de todo o mundo dispostas a se hospedar em seus "confortáveis" apartamentos gelados, com temperaturas a menos de cinco graus Celsius.

Arquitetos e designers são anualmente convidados a participar de concursos para o projeto e construção de cada UH, tornando os ambientes únicos a cada ano, e com uma arquitetura despojada que explora até mesmo a transparência e, conseqüentemente, a luminosidade que o material das paredes, piso e teto (gelo) pode proporcionar.

Os edifícios hoteleiros representam uma tipologia arquitetônica que abriga diversas funções tanto para atender diretamente os hóspedes e usuários - os apartamentos, quando para atendê-los indiretamente - as áreas administrativas e de serviços. Para todas elas a busca é sevir ao hóspede, um cliente exigente, oferecer o melhor serviço com o maior conforto e, de preferência, pelo menor preço.

\subsection{Aspectos históricos: o surgimento e a evolução dos hotéis}

Para o entendimento do mercado Hoteleiro, a pesquisa buscou inicialmente apresentar os aspectos históricos do surgimento dos Hotéis no Brasil e no Mundo, descritos a seguir. 


\subsubsection{Origem e expansão hoteleira}

As primeiras redes hoteleiras surgiram na Europa, na segunda metade do séc. XIX, quando eram necessárias grandes mobilizações de capital para a construção e a operação dos grupos de empresas multinacionais. Entretanto, foi somente após o término da Segunda Grande Guerra que o setor hoteleiro mundial cresceu significativamente, diversificando-se com o aumento das viagens de lazer e negócios, motivadas pelo crescimento econômico e pela melhoria da renda da população.

Nos anos 70, as grandes empresas aéreas buscavam complementar seus serviços de transporte com a hospedagem, adquirindo assim redes locais de hotéis ou organizando novas cadeias, como resposta ao crescimento da demanda. Segundo a OMT (Organização Mundial de Turismo, do inglês World Tourism Organization, WTO), entre 1950 e 1989, o número de turistas internacionais aumentou 11 vezes, passando de 25,3 milhões para 283,1 milhões por ano (ANÁLISE SETORIAL, 1999).

Porém, entre 1980 e 1982, após uma das crises do petróleo, o número de desembarques de turistas no mundo todo reduziu. Em decorrência disso, nessa mesma década, ocorreu um intenso processo de fusões e aquisições entre as operadoras hoteleiras. A intenção era aumentar as escalas operacionais e diversificar os locais de atuação por meio da organização de grandes redes internacionais, buscando encontrar uma alternativa para a crise econômica.

\subsubsection{As redes hoteleiras no Brasil}

Durante o início dos anos 60, surgiram as primeiras iniciativas do poder público para estimular o desenvolvimento do turismo no Brasil. Nessa época, foram criados programas de incentivo à construção de hotéis de categoria intermediária, com o objetivo de expandir e adequar o parque hoteleiro às suas atividades.

Na década seguinte, com o desenvolvimento da infra-estrutura dos transportes aéreo e rodoviário e o crescimento econômico, novos empreendimentos foram desenvolvidos, inclusive no setor turístico, incentivados pelo surgimento da Empresa Brasileira de Turismo (EMBRATUR) em 1966. Nessa época, a maior parte das redes internacionais de hotéis associou-se a algum grupo nacional, fato que trouxe como resultado a diversificação dos serviços de hospedagem oferecidos e o aumento da profissionalização no setor.

Com a implantação do Plano Real na economia brasileira, a partir de 1994, e a estabilidade econômica, a procura por hotéis de padrão econômico e interme- 
diário aumentou, abrindo espaço para os flats ${ }^{3}$, ou apart-hotéis. As unidades de flats distinguem-se dos apartamentos de hotéis por oferecerem um ambiente de sala-cozinha que permite ao usuário preparar suas refeições e se acomodar com um pouco mais de espaço do que em uma UH de um hotel. Oferecem-se, assim como nos hotéis, serviços de governança (limpeza e arrumação), o que torna ainda mais confortável a estada.

Outra característica dos flats é a forma diferenciada de captação de recursos para sua implantação. As unidades de flats são vendidas de forma pulverizada para pequenos e médios investidores, que posteriormente as colocam a serviço de uma administração centralizada. As taxas recolhidas sobre essas unidades diferem das taxas dos hotéis, uma vez que se caracterizam como residência, embora tenham toda a infra-estrutura e serviços de um hotel.

Após 1994, o setor hoteleiro entrou em uma nova fase de expansão, motivada pelo aumento da entrada de estrangeiros no país. Entre 1995 e 1997, esse aumento foi de 10,2\% (ANÁLISE SETORIAL, 1999), conseqüência do crescimento das viagens de negócios, eventos e turismo em geral. Na pesquisa de 1997, realizada no Brasil pela empresa Horwath Consulting, as viagens de negócios e turismo eram responsáveis pela maior parte da ocupação dos hotéis independente da categoria, como mostra a TAB. 1.

\subsection{Critérios de classificação dos hotéis}

O grande crescimento das viagens domésticas e internacionais a partir dos anos cinqüenta, fez com que órgãos públicos e privados questionassem as tarifas de hotéis no mundo. Com isso, a Organização Mundial de Turismo (OMT) criou a classificação dos hotéis. Em seguida, a Associação de Restaurantes e dos Hotéis Internacionais (IR\&RA) foi designada para levantar os dados do setor privado. Ao mesmo tempo, a OMT, juntamente com o a administradora dos membros nacionais de turismo, responsabilizaram-se pelo levantamento de dados do setor público (WTO, 2006).

O resultado final foi um comparativo de trinta e um países levantados pelo setor privado e outros oitenta e nove pelo setor público. Do universo analisado,

3. Os flats são uma mistura de residência e hotel, foram criados para atender as pessoas que permanecem numa mesma cidade por um tempo longo demais para se hospedar num hotel (o que implica custo muito elevado), mas não o suficiente para estabelecer um domicílio. 


\begin{tabular}{|lcccc|}
\hline \multicolumn{4}{|c|}{ TABELA 1: OCUPAÇÃO POR MOTIVO DE VIAGEM - DADOS DE 1997 (\%) } \\
\hline Categoría e hotel & Negócio & Turismo & Convenções & Outros \\
\hline Luxo & 38.70 & 27.60 & 20.10 & 13.60 \\
\hline Intermediário & 42.1 & 31.30 & 13.20 & 13.40 \\
\hline Econômico & 40.80 & 40,90 & 8.80 & 9.50 \\
\hline
\end{tabular}

Fonte: ANÁLISE SETORIAL, 1999.

oitenta e três paises já possuíam sua própria classificação oficial local (classificação nos hotéis, flats, motéis e inns ${ }^{4}$ ), e os outros vinte e três países não as possuíam.

\subsubsection{O modelo da OMT}

Em vinte e três países nos quais o setor público é o responsável pela classificação, utilizam-se as tarifas dos hotéis como forma de controle dos governos, enquanto que em treze países a classificação é apenas instrumento de diferenciação das taxas a serem aplicadas nos empreendimentos.

Na grande maioria dos países (quarenta e nove do total) a classificação dos hotéis segue as Administradoras Nacionais de Turismo, em conjunto com a Associação Nacional dos Hotéis.

Em quarenta e seis países, a classificação é obrigatória em todos os estabelecimentos. Em outros cinqüenta e cinco, ela é necessária para a aquisição da licença de operação. Segundo a OMT, em trinta e dois países a operação de um hotel independe da existência da classificação.

(...) para ser sustentável, o turismo precisa ser capaz de consolidar sua diversidade, não buscar a uniformidade. Caso contrário, qualquer busca regional, ou até mesmo global, de harmonização do que pode apenas ser um sistema voluntário, irá sob a aparência de organização, acabar criando mais confusão (WTO; IH\&RA, 2005, p.3) .

4. Inn: originário da palavra em inglês inkeeper, que significa hospedaria. Antigamente eram os bares que algumas vezes ofereciam hospedaria e estábulo para viajantes e seus cavalos, respectivamente. 
O Brasil está entre os países em que a classificação não é usada para regular as tarifas nem diferenciar o imposto aplicado nas diferentes categorias, favorecendo a diversidade, elemento que a própria OMT considera importante para o melhor funcionamento do mercado hoteleiro.

\subsubsection{Redes internacionais}

As principais redes hoteleiras no Brasil não utilizam a classificação regulamentada pela EMBRATUR, mas introduzem a idéia de que a própria marca do estabelecimento determina o padrão de serviço e a tarifa, variando de acordo com a bandeira ${ }^{5}$ do hotel. Dessa forma, todos os hotéis de uma mesma bandeira, como estratégia de marketing, respeitariam características mundiais traçadas pela rede.

Esse conceito, mais adequado a um novo tempo, no qual a clientela se desloca com maior freqüência pelo planeta, estabelece, de antemão, uma expectativa do tipo de serviço e padrão de estabelecimento a ser encontrado. No entanto, esse modelo desvaloriza a credibilidade da EMBRATUR, que deveria ser vista como órgão regulador e organizador de todo o mercado hoteleiro brasileiro.

\subsubsection{EMBRATUR}

Órgão controlador do turismo brasileiro desde 1978, a EMBRATUR, regulamenta todas as diretrizes a serem seguidas pelo turismo nacional, entre elas, a classificação das categorias dos hotéis. O primeiro sistema de classificação adotado pela EMBRATUR baseava-se no modelo da OMT, que por sua vez, adotava a simbologia das estrelas $^{6}$ (IL. 7). Em 1996, por meio da Deliberação Normativa $\mathrm{N}^{0} 360$, a diretoria da EMBRATUR decidiu cancelar o então sistema brasileiro de classificação de meios de hospedagem e turismo, revogando as matrizes vigentes, por sua baixa credibilidade e características ultrapassadas.

Em seguida, um novo sistema foi sugerido sem ter sido, efetivamente, adotado na hotelaria. Esse novo sistema definia as categorias hoteleiras em: simples, standard, standard superior, luxo e super luxo. Em 23 de abril de 2002, por meio da Deliberação Normativa $\mathrm{N}^{0} 429$, o então Ministério do Esporte e Turismo aprovou

5. Denomina-se bandeira de um hotel como a "marca de uma empresa responsável, exibida em cada agência ou posto de venda integrante de uma rede própria ou franqueada" (HOUAISS; VILLAR, 2004).

6. De uma a cinco estrelas, elas representam a hierarquia das categorias hoteleiras, sendo uma os hotéis simples e cinco os hotéis super luxo. 


\begin{tabular}{|c|c|c|c|}
\hline Categoria & Símbolo & Categoria & Símbolo \\
\hline Super Luxo & $\star \star \star \star \star S L$ & Turístico & $\star \star \star$ \\
\hline Luxo & $\star \star \star \star \star ~$ & Econômico & $\star \star$ \\
\hline Superior & 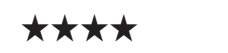 & Simples & $\star$ \\
\hline
\end{tabular}

Ilustração 7: Hierarquia da classificação das categorias hoteleiras representadas por símbolos Fonte: EMBRATUR, 2002.

o Regulamento do sistema Oficial de Classificação dos Meios de Hospedagem, gerando retificações no documento intitulado Matriz de Classificação, determinando o processo de classificação dos empreendimentos hoteleiros.

Neste processo de classificação, a determinação dos critérios e a avaliação dos hotéis a serem categorizados de acordo com estes critérios é, desde 2003, responsabilidade da EMBRATUR e da Associação Brasileira da Industria de Hotéis $(A B \mid H)$. Enquanto o primeiro determina os critérios, o segundo avalia os Hotéis.

Até os dias de hoje este é o regulamento que passa a estabelecer o conceito de empresa hoteleira, os requisitos para a operação, o funcionamento dos estabelecimentos e as condições de contratação dos serviços de hospedagem. Dentro dos requisitos exigidos, encontram-se os aspectos construtivos, as instalações, os equipamentos e os serviços exigidos por cada categoria hoteleira.

\subsubsection{Outros critérios}

Outras formas de classificar hotéis surgiram com a necessidade de sistematizar o mercado de forma didática, compreendendo as variações dos meios de hospedagem e suas diferenças (DUARTE, 2005). Elas seriam classificadas pelo tempo de retorno do investimento (do inglês, payback), como no exemplo descrito abaixo.

A. Quanto ao tamanho dos hotéis: Baseada na resolução No 1023 do Conselho Nacional de Turismo (CNTUR), órgão normativo do Ministério da Indústria, Comércio e Turismo, leva em consideração o número de UH que possui para a venda. Os tamanhos são determinados conforme a TAB. 2.

B. Quanto à administração dos hotéis: que seriam subdivididas da seguinte forma:

- Proprietários particulares - com administração familiar;

- Redes ou cadeias hoteleiras - com uma mesma estrutura contábil; 


\section{TABELA 2: CLASSIFICAÇÃO DE HOTÉIS DE ACORDO COM TAMANHO DO HOTEL}

\begin{tabular}{|ll|}
\hline Tamanho & Número de UH \\
\hline Pequeno & Até 40 \\
\hline Médio & De 41 a 200 \\
\hline Grande & Mais de 200 \\
\hline
\end{tabular}

Fonte: DUARTE, 2005.

- Franquias - que estabelecem parceria na área comercial com uma empresa franqueadora, ou até mesmo por meio do pagamento de royalties, taxas e comissões.

C. Quanto ao valor das diárias: baseadas numa ocupação de vinte e quatro horas, as diárias poderão ser:

- simples (sem café da manha);

- com café da manhã;

- pensão completa (todas as refeições inclusas na diária);

all included ${ }^{7}$.

D. Quanto ao principal produto, a UH pode ser segmentada da seguinte forma:

- UH típica (mínimo obrigatório definido pela EMBRATUR que hoje representa $51 \%$ do total das unidades).

- UH atípica (todas as características diferentes das unidades típicas)

- Unidade Habitacional Luxo (UH com melhor acabamento e ou localização);

- Suíte (UH com mais um ambiente, além do quarto e banheiro);

- UH conjugadas (dois quartos e um banheiro);

- UH comunicantes (dois quartos com alguma comunicação física, como porta, por exemplo).

E. Quanto à ocupação do principal produto, entendida como a classificação pelo número de pessoas acomodadas. Seriam elas:

- single: utilizada apenas por uma pessoa;

- duplo: utilizada por duas pessoas;

- triplo: utilizada por três pessoas;

- quádruplo: utilizada por quatro pessoas.

7. Do termo em inglês, tudo incluso - que significa que todas as refeições estão inclusas no valor da diária e uma carta de bebidas alcoolólicas ou não. 


\begin{tabular}{|c|c|c|}
\hline Tipos de hotéis & Localização & Finalidade \\
\hline $\begin{array}{l}\text { Executivos: voltados } \\
\text { ao público gerado } \\
\text { por empresas, em } \\
\text { viagens de negócios, } \\
\text { reuniões ou eventos }\end{array}$ & $\begin{array}{l}\text { Centro, aeroporto, } \\
\text { rodoviária, } \\
\text { centro comercial, } \\
\text { industrial, etc. }\end{array}$ & $\begin{array}{l}\text { Residência provisória, } \\
\text { longa e média } \\
\text { permanência, pernoites, } \\
\text { day-use (uso da umidade } \\
\text { habitacional somente } \\
\text { durante o dia), reuniões. }\end{array}$ \\
\hline $\begin{array}{l}\text { Lazer ou saúde: } \\
\text { voltados para } \\
\text { atender à família, } \\
\text { à terceira idade e } \\
\text { a pacotes turísticos } \\
\text { e convenções. }\end{array}$ & $\begin{array}{l}\text { Praia, campo, } \\
\text { montanha, estância } \\
\text { hidromineral/ } \\
\text { climática, etc. }\end{array}$ & $\begin{array}{l}\text { Entretenimento, } \\
\text { renovar energia, uso } \\
\text { terapêutico, etc. }\end{array}$ \\
\hline
\end{tabular}

Fonte: DUARTE, 2005. Adaptação da autora.

F. Quanto ao mercado: baseado em função do principal público consumidor, conforme indica a TAB. 3 .

G. Quanto ao capital social de hotéis: define se o empreendimento é:

- uma empresa individual;

- uma sociedade por cotas limitadas ou anônima;

- sociedade em conta de participação.

Todos as classificações apresentadas anteriormente demonstram a grande variedade de formas como um hotel pode ser classificado, sendo a classificação mais popularmente adotada aquela que segue os critérios da EMBRATUR, apresentados na IL. 7, na página 19.

\subsection{Indicadores de sustentabilidade}

A crise energética mundial, derivada das crises do petróleo e, mais recentemente, da preocupação com as emissões de gases causadores do efeito-estufa, desencadearam iniciativas para minimizar os problemas relacionados ao impacto ambiental, entre eles a avaliação da eficiência energética de edifícios. 
Segundo Jones (1998), a análise do ciclo de vida dos edifícios é a forma mais adequada para avaliar o seu desempenho ambiental, que considera desde a extração dos materiais utilizados, a construção e o uso, até a fase de demolição.

A partir da década de 9o, países da Europa e os EUA desenvolveram metodologias para avaliação ambiental de edifícios, visando sua eficiência energética e seguindo o conceito de construção sustentável. O objetivo de uma construção sustentável, segundo Vosgueritchian (2006), é a criação, construção e administração de um ambiente saudável, baseadas em princípios eficientes e ecológicos. Consideram-se as questões ambientais e de qualidade de vida, bem como de equidade social, cultural e econômica.

O desenvolvimento sustentável, segundo definição da ONU (1987, apud WERNECK, 2003) é um modelo de desenvolvimento que responde às necessidades das gerações atuais, mas que não compromete a possibilidade das gerações futuras de satisfazer suas necessidades nesse mesmo futuro.

Os indicadores de sustentabilidade são necessários para medir o desempenho da indústria da construção e do ambiente construído de acordo com critérios pré-determinados. Segundo Vosgueritchian (2006), trata-se de um dos mecanismos mais efetivos para a construção de cidades mais sustentáveis.

Existem hoje no mundo acima de 40 sistemas de avaliação que utilizam mais de 500 indicadores, tanto do ponto de vista energético, como ambiental, social, cultural e econômico. Entre eles, os mais conhecidos são: o LEED (americano), BREEM (Inglês), GBToll (Canadense), HQE (Francês), CASBEE (Japonês).

O Brasil ainda não possui nenhum indicador de sustentabilidade (SILVA, 2003), no entanto, um modelo para a avaliação de sustentabilidade de edifícios de escritório foi desenvolvido por Silva (2003).

Enquanto isso, o mercado da construção civil (escritórios, escolas, bancos, hotéis, entre outros) tem buscado a certificação ambiental, o "selo verde" por meio de certificadores estrangeiros, com destaque para o americano Leadership in Energy and Environmental Design (LEED).

As empresas brasileiras, tem buscado estes certificadores estrangeiros como estratégia de marketing para divulgar seu produto como selo verde. Porém, como eles não são adaptados a realidade brasileira, podem resultar em situações em que edifícios obtenham o certificado sem que exista verdadeiramente uma garantia a qualidade ambiental.

Em editorial recente, o jornal inglês The Guardian, sintetizou muito bem essa questão: 
Muita publicidade e prática ruim: esta é certamente a receita para o cinismo popular, no momento em que a população demonstra um interesse real nas questões do meio ambiente (THE GUARDIAN, 2007).

O problema ambiental e o aquecimento global devem ser analisados de forma consciente, por meio da adoção de medidas adequadas para cada realidade, cada país e, no caso brasileiro, cada região climática.

Seguindo a tendência mundial como estratégia de marketing das empresas hoteleiras para serem reconhecidas pela responsabilidade ambiental, esses certificados ambientais têm sido alvo de interesse também de hotéis.

O primeiro a receber o selo LEED foi o Hotel Hilton Vancouver, em Washington, da rede Hilton Hotéis (LIBBY, 2005), fato noticiado com destaque pela imprensa mundial. Depois dessa divulgação, o gerente do referido hotel definiu como meta obter o selo verde das operações hoteleiras: o Green Seal, específico do ramo hoteleiro, desenvolvido pela Organização Não Governamental (ONG) que promove a manufatura, compra e uso de produtos e serviços ambientalmente responsáveis. 0 mesmo hotel obteve o selo verde em 2007. Com $782 \mathrm{UH}$, ele foi reconhecido pela oportunidade de reduzir o impacto ambiental, substituir produtos tóxicos por outros ecologicamente corretos ${ }^{8}$, economizar energia e dinheiro (HILTON, 2007).

A questão tem sido tão valorizada para os hotéis que Chandler (2007), uma especialista em consumo e tendência de saúde e meio ambiente, elaborou uma lista de estratégias dirigida a empresários do setor hoteleiro, as quais visam valorizar as medidas adotadas pelo hotel para que seus hóspedes tornem-se seus aliados no que se poderia chamar de "campanha do selo verde". Algumas das estratégias descritas pela autora são:

- Explicar porque o hotel é certificado como "hotel verde".

- Explicar a importância de conservar os recursos naturais e como o hotel se comporta a este respeito.

- Incentivar os hóspedes a reutilizar os lençóis e toalhas, explicandoo os motivos desse procedimento.

Essa preocupação também aparece em âmbito mais global. O conselho mundial de viagens e turismo (WTTC, sigla em inglês) lançou uma campanha internacional no início de 2007, evidenciando as questões das mudanças climáti-

8. Ecologicamente correto: que causa menores danos ao meio ambiente, desde a extração dos materiais da natureza, até o descarte do produto após o uso. 
cas. Segundo o presidente da WTTC, Jean-Claude Baumgarten, a preocupação com a crise energética tem forçado o setor de turismo a repensar os níveis de consumo de energia elétrica, tornando-se necessária a busca por alternativas (WTTC, 2007). Os líderes do segmento de viagens e turismo estão buscando trabalhar melhor para reduzir as emissões de carbono na atmosfera causadas por suas atividades (hospedagem e transporte, principalmente), bem como no impacto global do setor no meio ambiente.

Dessa forma, nota-se que tendência de que os empreendimentos hoteleiros sejam capazes de se destacar no mercado também devido à capacidade de redução de seu impacto ambiental, processo no qual seus projetistas, arquitetos, funcionários, hóspedes e clientes desempenham papel importante.

\subsection{Estratégias de adaptação ao mercado}

As redes hoteleiras internacionais tendem a dominar o mercado e vêm crescendo vertiginosamente na cidade de São Paulo. Elas adotam padrões de arquitetura que se dizem adaptados à realidade do clima local, resultando em projetos com padrões pré-determinados, independentemente de sua localização geográfica.

A maioria das grandes redes hoteleiras apresenta o mesmo estilo de arquitetura, mantendo um padrão similar de apartamentos e serviços, e assim se tornando sinônimo de impessoalidade. Entre as características das bandeiras econômicas, destacam-se as diárias baixas e o número de funcionários significativamente inferior à média dos hotéis de categoria de três ou mais estrelas (conforme a classificação oficial da EMBRATUR). Estas operam em diversas atividades (multi-função), de modo que a redução de seus custos e o preço das diárias atraia um público crescente.

ZAKABI (2002) enumera os hotéis econômicos da rede Formule 1 e íbis dentre os que vêm apresentando as maiores taxas diárias de ocupação: 97\% e 75\%, respectivamente.

\subsubsection{Estratégias Operacionais das redes internacionais}

As redes operam com várias bandeiras de hotéis e flats, que buscam encontrar estratégias para se diferenciarem num mercado tão competitivo. Entre essas estratégias destaca-se a adoção de uma nova tendência, já bastante comum no 


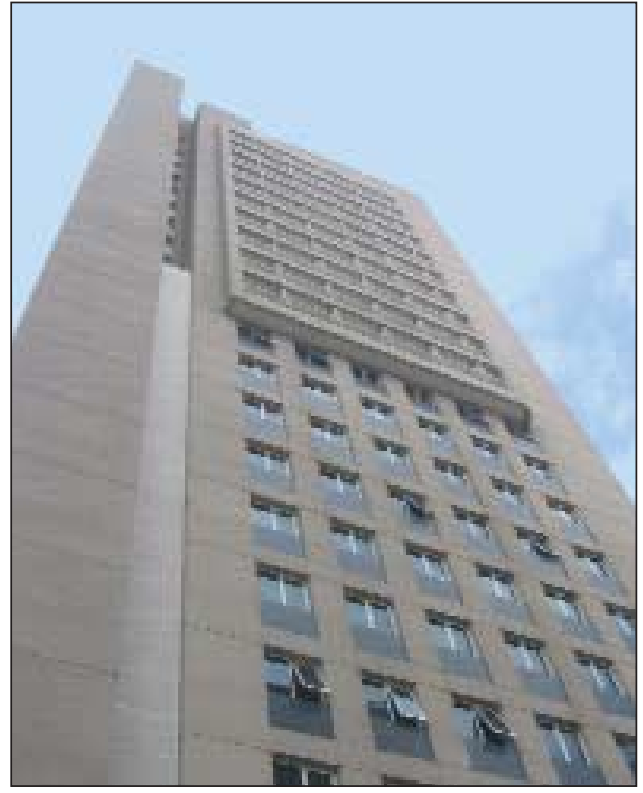

Ilustração 8: Hotel econômico em São Paulo (9 andares superiores) e escritórios (8 andares inferiores): sistema split com leitura individual

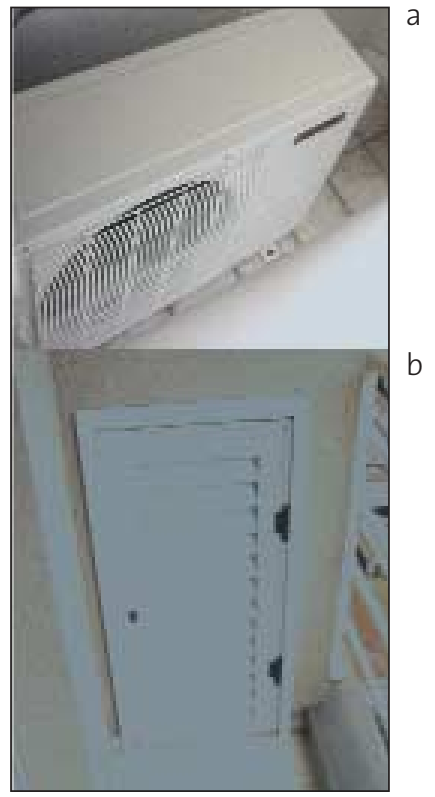

Ilustração 9: Condensador (a) com acesso restrito apenas para equipe de manutenção; porta de acesso (b)

mercado europeu: a construção de edifícios com usos diversificados, como hotéis e escritórios. No exemplo da IL. 8, vê-se o Hotel Comfort Moema, da Rede Atlântica, um edifício de uso misto, no qual os primeiros seis andares, depois dos dois andares administrativos são ocupados por salas de escritórios e os últimos, por UH do hotel.

Neste exemplo, foram incorporadas medidas que facilitam a operação do hotel e a viabilidade do empreendimento, que é a leitura individualizada do consumo de energia por UH. A solução estética, pelo mesmo motivo, diferencia os andares dos apartamentos dos andares de escritório, para que o sistema de ar condicionado (SAC) não atrapalhe a composição estética da fachada do edifício.

O SAC funciona de maneira diferenciada nos dois casos: nos apartamentos, possuem nichos na varanda, com acesso restrito para a equipe de manutenção (IL. 9), protegido do Sol, com tomada de ar externo; nos andares de escritórios, o sistema multi-split de ar condicionado atende o andar inteiro. Assim, cada andar de escritório possui um medidor de consumo energético único, bem como as $\mathrm{UH}$, atendendo às suas necessidades de controle individual.

Os avanços provocados pela entrada das grandes redes hoteleiras internacionais no Brasil contribuíram significantemente para aprimorar o desenvolvimento e a modernização do setor, além da internacionalização do padrão de qualidade nos serviços, colocando seus hotéis nas principais centrais de reservas internacionais. 
Como conseqüência, destacam-se os questionamentos relativos aos efeitos danosos da entrada das redes sobre a hotelaria instalada, e sua duvidosa contribuição ao setor. Segundo Lima (2003), seria duvidosa porque a tendência do mercado é ser dominada por essas redes, as quais tendem a eliminar os chamados hotéis independentes. A mesma autora completa essa afirmação, reforçando o fato de que, caso não existam "limites da lei", os hotéis tradicionais independentes, que não participam de grupos e ou redes, estarão com seus dias contados.

Em sua maioria, estes estão instalados em edifícios mais antigos, com arquitetura tradicional de concreto armado e sem grandes centrais de reserva, tais como as das redes internacionais.

\footnotetext{
Alguns de nossos companheiros de hotelaria identificam os problemas nas bandeiras 'internacionais' que estão entrando cada vez mais pesadamente em tais projetos. Inicialmente, cabe esclarecer que, na quase totalidade dos casos, as grandes redes, as 'bandeiras' hoteleiras mais conhecidas no Brasil e no mundo, não investem em imóveis (REVISTA HOSPEDAGEM BRASIL, 2002, p.27).
}

Em Lima (2003) Adilson Barreto Filho, Diretor de Redes Nacionais da ABIH do Rio Grande do Sul destacou que os pesquisadores sobre o tema estão identificando uma grande ameaça para os hotéis brasileiros independentes, chegando até a perspectiva da saída do mercado. "Parece pessimismo, mas a realidade está direcionando para esta triste conclusão" (Lima, 2003).

Pode-se então concluir que as redes internacionais tendem a dominar o mercado no setor dos hotéis econômicos, ao mesmo tempo em que buscam criar estratégias que as diferenciem neste mercado.

\subsubsection{O caso do Maksoud}

Diante do avanço cada vez maior das redes internacionais no Brasil, o famoso Hotel Maksoud, situado a uma quadra da Avenida Paulista em São Paulo, em funcionamento há 27 anos, foi, durante anos, o hotel mais luxuoso de São Paulo, posto que não ocupa mais desde o surgimento das bandeiras luxuosas das redes internacionais.

No ano de 2007, a administração do hotel Maksoud criou uma nova estratégia de marketing, o conceito de "4 hotéis em 1": padrões diferenciados de apartamentos que vão desde suítes simples de baixo custo nos três primeiros andares, suítes executivas nos 4 andares seqüenciais e nos outros 4 , o que denominam a 
Torre Premium, com outros apartamentos e suítes, além de dois andares presidenciais (VITRINE HOTEL, 2007).

Essa alteração manteve o mínimo exigido pela EMBRATUR, que é manter $51 \%$ das UH típicas do hotel, conforme foi apresentado anteriormente, segundo o critério de classificação de principal produto de Duarte (2005).

Se cada novo hotel de rede construído representasse uma redução no mercado dos hotéis tradicionais (como o Maksoud) para a sobrevivência desses hotéis, a tendência seria que se criassem estratégias como esta, em busca do retorno do púbico que pode acabar migrando para os hotéis de redes internacionais.

\subsection{A tendência mundial}

Na Europa, segundo as informações disponíveis nas publicações internacionais recentes (AIT, 2006), podem-se ver algumas tendências na arquitetura hoteleira em geral, que serão apresentadas a seguir.

O Hotel Cube, localizado no Alpes Europeus (IL. 10) foi projetado pelo escritório de arquitetura Baumschlager-Eberle e pensado para atrair uma "comunidade de pessoas com a mesma mentalidade", conforme mencionou o próprio arquiteto. Possui amplas áreas comuns, sabendo-se de antemão que os hóspedes não permaneceriam nos apartamentos durante sua estada no hotel.

As UH possuem acabamentos simples com cores fortes, deixando o ambiente com aparência mais moderna e alegre. Elas são compactas e posicionados no contorno do edifício de forma quadrada, como mostra a IL. 11, na parte central do edifício concentram-se as atividades de uso comum: recepção, restaurante, saguão e lojas.

Por se tratar de hotel de lazer, próximo às estações de esqui, todos os apartamentos possuem um saguão na entrada, para abrigo do material de esqui. Além disso, a circulação vertical projetada com as amplas rampas centrais facilitam a circulação dos hóspedes com esses equipamentos dentro do hotel.

Outro edifício de pequeno porte $(36 \mathrm{UH})$, o Hotel Braumaunufaktur localizado na Alemanha, foi projetado pelo arquiteto Ulrich Schwille e, segundo ele, os apartamentos foram construídos com a máxima economia de energia elétrica e alta qualidade (AIT, 2006). Merece destaque a originalidade do lay-out (disposição da cama e dos armários) e os materiais de acabamento dos apartamentos (madeira de pinus e concreto aparente), conforme apresentado na IL. 12. A planta não é tão compacta quanto à dos hotéis econômicos apresentados na seção 3, a seguir, 

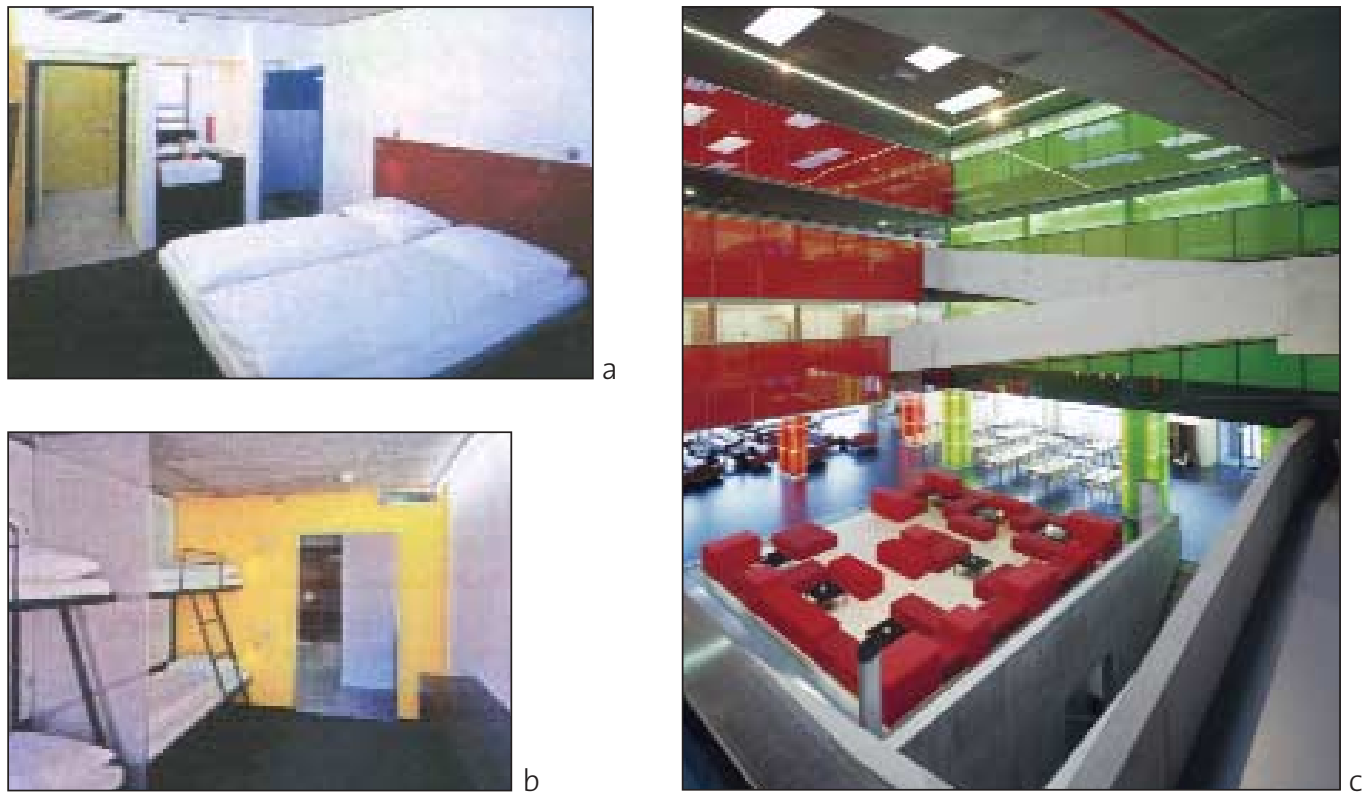

Ilustração 10: Hotel Cube - Savognin (Europa): opção de quarto para duas ou quarto pessoas (a e b respectivamente); atrium central espaçoso com restaurante, área de encontro e recepção (c). Fonte: AlT, 2006.

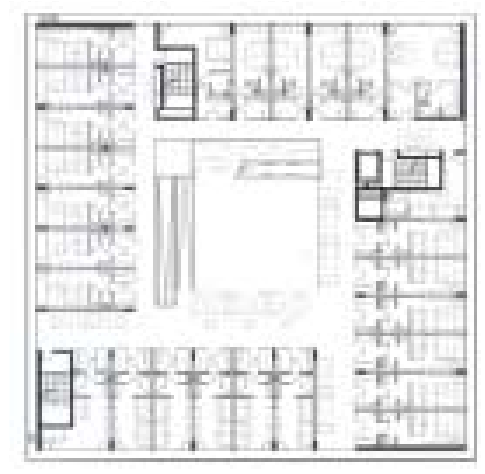

a

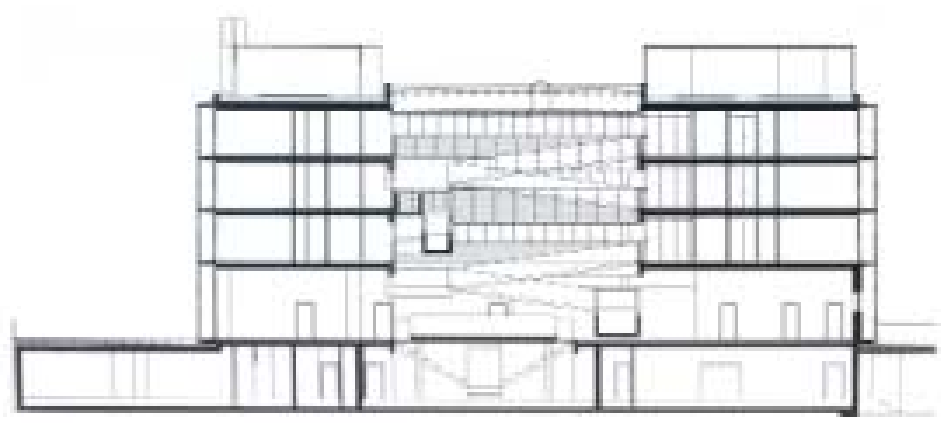

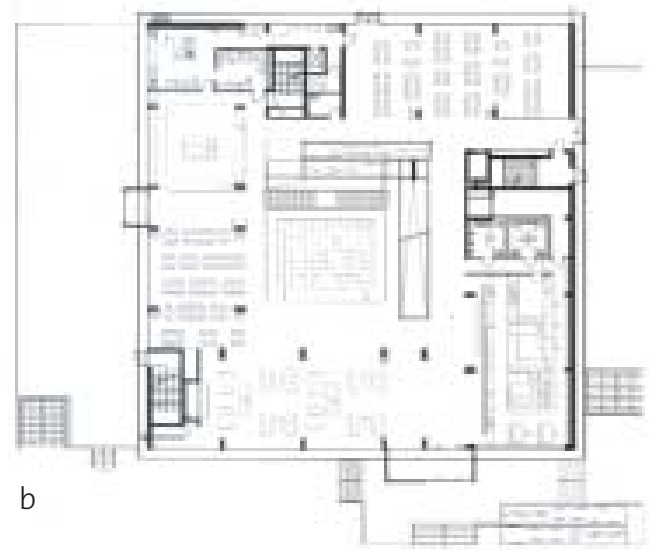

Ilustração 11: Hotel Cube - Savognin (Europa): segundo piso (a), primeiro piso (b) e corte longitudinal (c).

Fonte: AlT, 2006. 

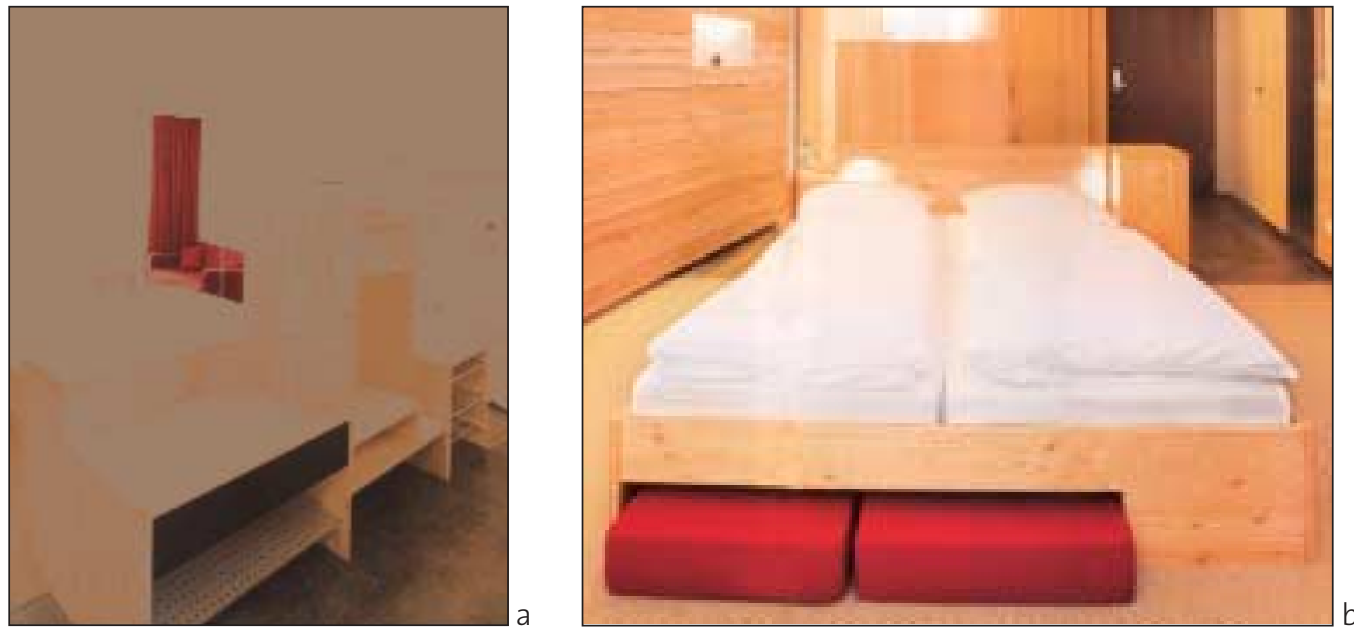

Ilustração 12: Hotel Braumaunufaktur - Alemanha; Desenho de mobilbiário compacto com armário e bancada de um lado da cama (a), e camas extras embutidas (b) do outro lado. Fonte: AlT, 2006.

no entanto existe uma preocupação com a orientação dos apartamentos (quase todos na mesma face). No corredor, uma faixa de carpete delimita a área da circulação de pessoas do aparato que protege os radiadores que aquecem esse ambiente. O carpete auxilia também na absorção da acústica interna e as aberturas para o exterior deixam o ambiente de circulação mais agradável, com fachos de luz natural entre as UH. No projeto, o aquecimento nas UH ocorre através do piso nos apartamentos, sistema que pode reduzir o consumo de energia, se comparado ao sistema de aquecimento através de radiadores. Cabe salientar que o hotel em questão situa-se em região de clima temperado no hemisfério norte, sendo muito importante a adoção de estratégias eficientes para o aquecimento do ambiente, visando manter o conforto dos usuários a níveis aceitáveis.

Além disso, a iluminação indireta (projetada pelo escritório The Walking House) foi integrada ao mobiliário, acentuando ainda mais a simplicidade das soluções adotadas e o seu impacto visual na ambiência como um todo (conforme apresentado na IL. 13). Destacam-se também as camas extras, colchões vermelhos abaixo da cama de casal, integradas no mobiliário, um detalhe que compõe com o mobiliário básico.

O hotel do futuro ${ }^{9}$, denominado "Five + Sensotel", localizado em Willisau, Suiça, foi projetado por Yasmine Mahmoudieh como hotel de categoria cinco estrelas. Conforme se pode ver na IL. 14, o apartamento não é subdividido em

9. Hotel do futuro foi apresentado durante um congresso de hotéis em Londres - evento conhecido como Sleep 05, ocorrido de fevereiro a maio de 2005 (AIT, 2006). 

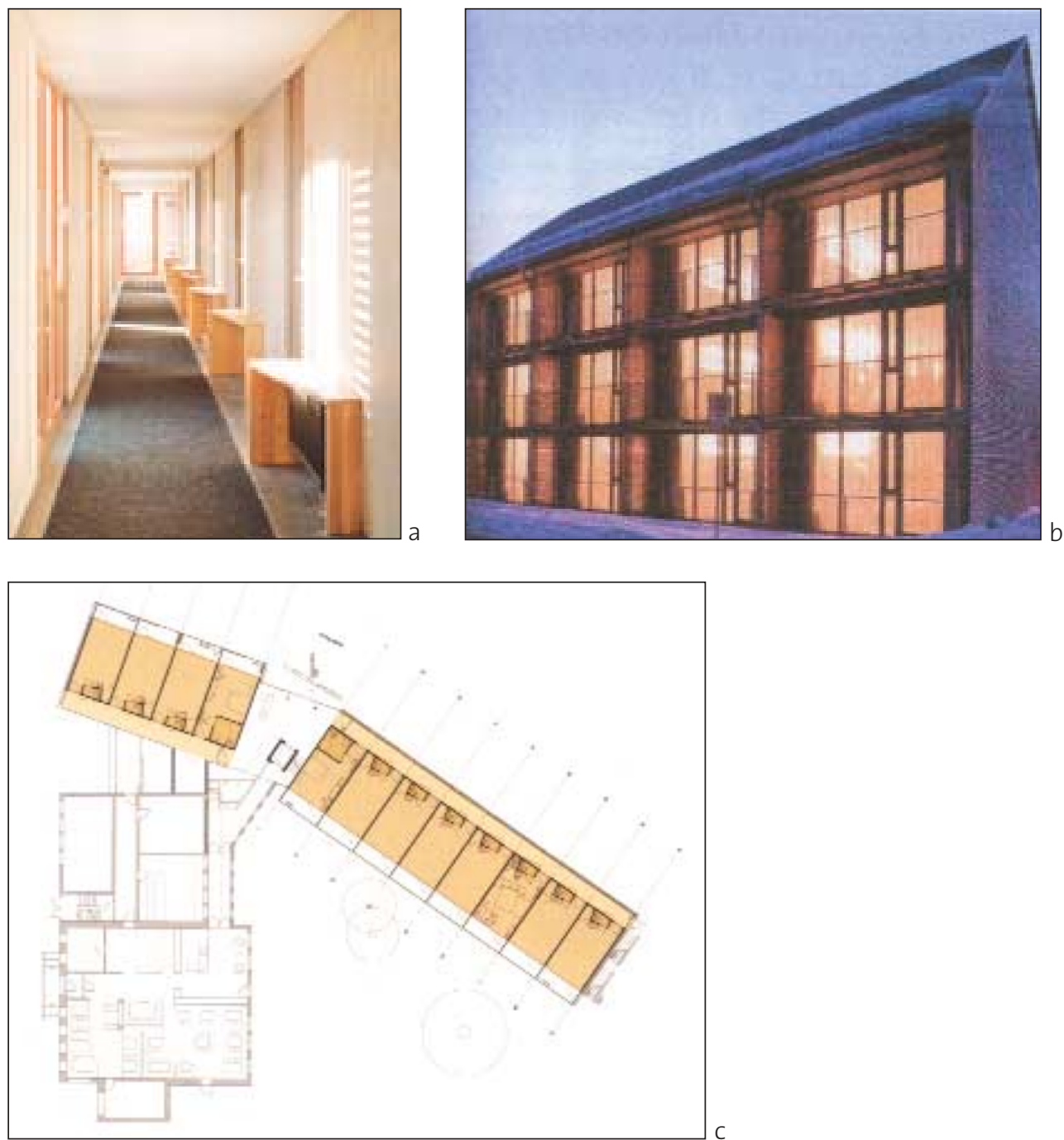

Ilustração 13: Hotel Braumaunufaktur - Alemanha; corredor (a), vista externa (b) e planta (c)
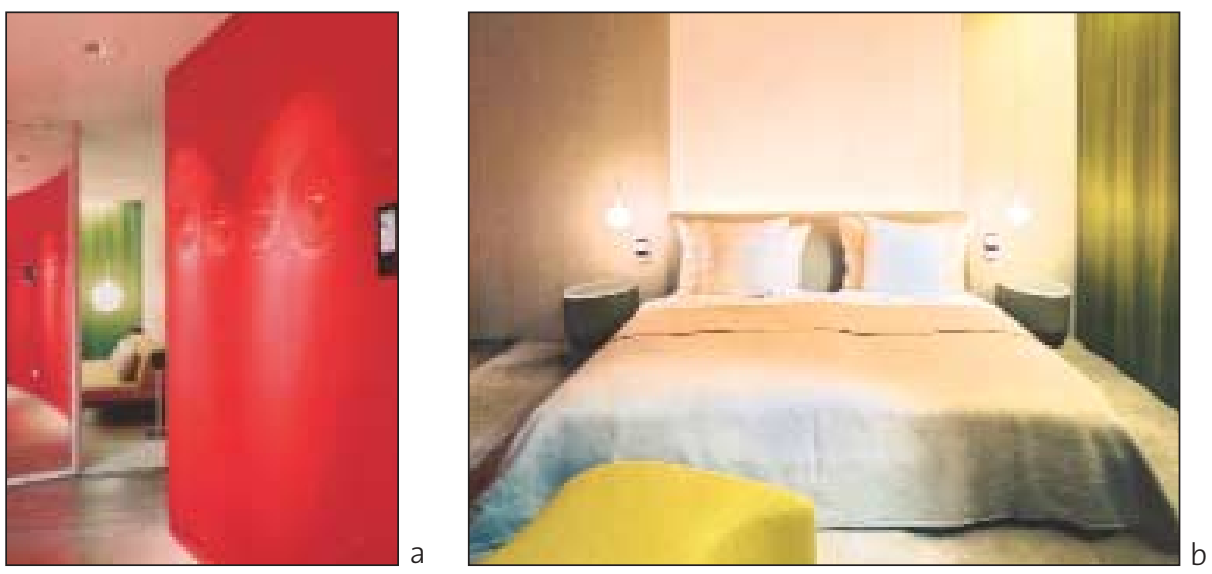

Ilustração 14: "Five + Sensotel"- Suiça; atmosfera tranqüila (a) e cabeceira com iluminação controlada (b)

Fonte: AlT, 2006. 
ambientes mas, segundo o arquiteto, em zonas espaciais com cores distintas, segundo a arquiteta, o foco central eram os aspectos das experiências sensoriais do hóspede, já que o bem estar está relacionado com a atmosfera do ambiente, e o desenho foi definido por uma percepção sensorial única, já que cada UH é diferente.

\footnotetext{
A intenção é mudar um apartamento de hotel com a visão de acomodação unicamente como pernoite para um espaço único com percepção sensorial para o desenvolvimento pessoal e de experiências (AlT, 2006).
}

Com essa intenção, a iluminação também possui fundamental importância, tendo sido projetada com três fontes distintas de luz, acionadas em circuitos independentes. Estas são capazes de simular as variações de iluminação natural ao longo do dia, podendo ser reguladas separadamente, de acordo com as necessidades do usuário. Essa solução pode auxiliar também na redução do consumo de energia elétrica.

A integração dos anseios do cliente com os do arquiteto podem fazer de um empreendimento hoteleiro um espaço único e com qualidade, sem deixar de lado a preocupação com o conforto dos usuários e a eficiência energética.

\subsubsection{O caso do edifício Shiodome - Japão}

No Japão, por se tratar de um país em que a regulamentação energética já está consolidada por lei (UNEP, 2007), a preocupação com o consumo de energia nos edifícios é ponto vital para sua construção, e que já esta sendo incorporada pelos arquitetos e engenheiros locais. Acrescenta-se a isso que o custo do $\mathrm{m}^{2} \mathrm{de}$ terreno é muito elevado, fazendo assim surgir edifícios altos, com coeficientes de aproveitamento elevados, e tecnologia de última geração para suportar os freqüentes terremotos típicos desta região.O exemplo mais popularizado divulgado na mídia é o da torre Shiodome, no Japão, que conseguiu o certificado ambiental canadense, o Green Building Challenge (GBtool), em 2005.

Trata-se de um edifício de uso misto: hotel (nos últimos 15 andares) e escritórios (nos primeiros 12 andares). Na IL.15, no corte esquemático do edifício, estão descritas as estratégias ambientais que norteiam o projeto do edifício. Tais estratégias incluem a opção de climatização (artificial, natural) separada nos dois usos do edifício, a integração do sistema artificial com sistemas passivos (o modo misto ${ }^{10}$ ), utilização de sistemas distritais para o fornecimento de água 


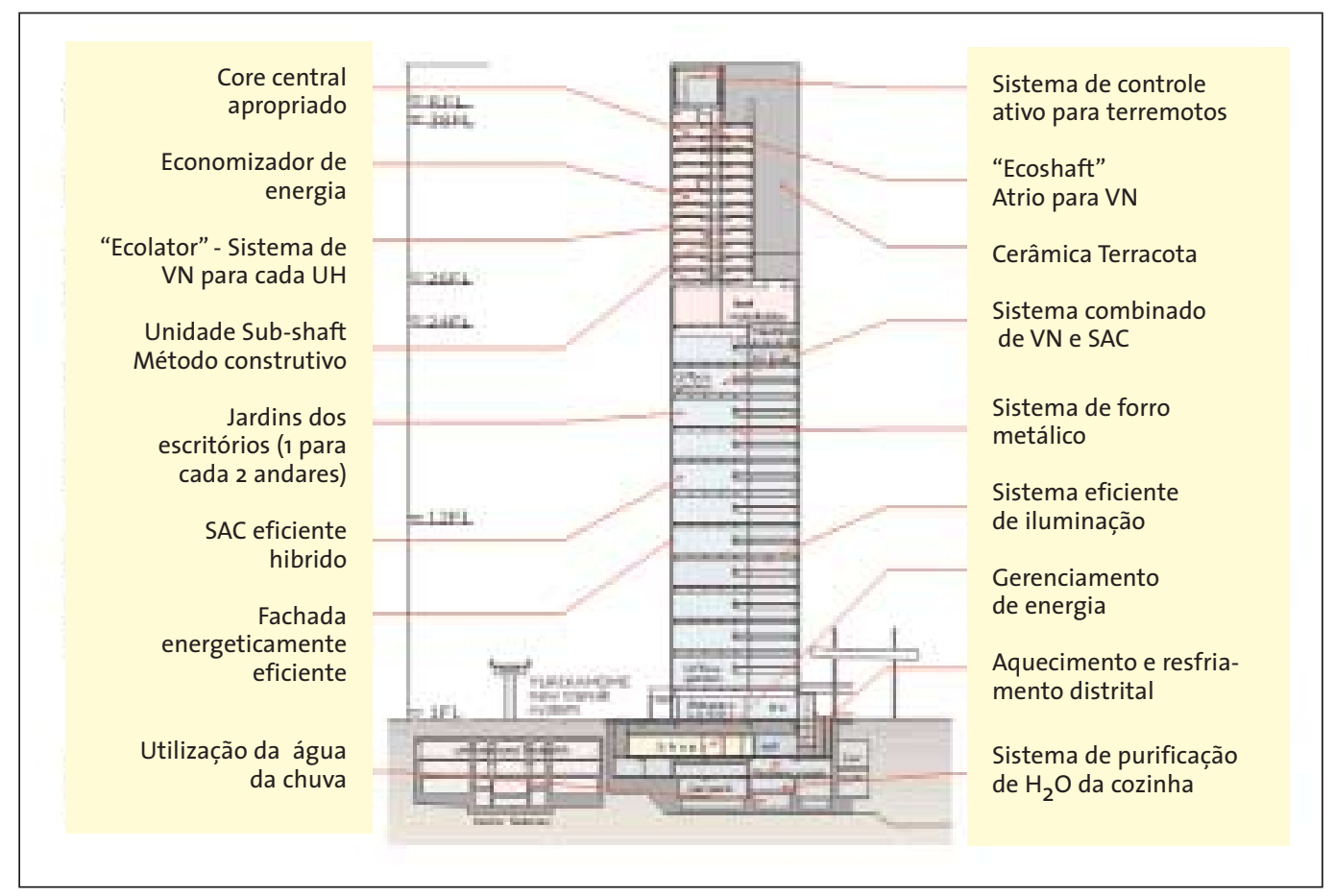

Ilustração 15: Corte esquemático com as estratégias da Torre Skiodome.

Fonte: WORDLGBC, 2007.

quente, "Ecoshaft" (átrio para VN) até a captação de água de chuva, entre outros.

A incorporação da arquitetura com estratégias que aprimoram a eficiência energética do edifício resultam em inúmeras soluções arquitetônicas como a escolha dos componentes construtivos das fachadas e a distribuição e a profundidade dos níveis do edifício. Nos andares de escritórios, parte do pavimento tipo possui pé-direito duplo, enquanto que nos andares restantes do hotel, o pé direito é simples, porém a planta é mais estreita do que a anterior. A UH de um hotel determina a ocupação do ambiente com mobiliário para dormir, bancada de trabalho, armários e eventualmente uma pequena área de estar. A distribuição deste mobiliário em um espaço com uma janela única difere da distribuição dos andares de escritório. Eles caracterizam-se por plantas livres e várias janelas ocupando o andar inteiro, ou seja, com profundidades de planta maiores do que no outro caso. Esta interpretação do espaço para cada uso que resultou em andares menores no Hotel comparados aos do escritório.

Dentre os modelos de apartamentos, podem-se encontrar dois padrões de

10. Entende-se como modo misto um sistema baseado no condicionamento natural integrado ao artificial com objetivo de reduzir o consumo de energia e aprimorando as condições de conforto dos usuários. Utiliza como índice de conforto o modelo adaptativo da ASHRAE 2004. 


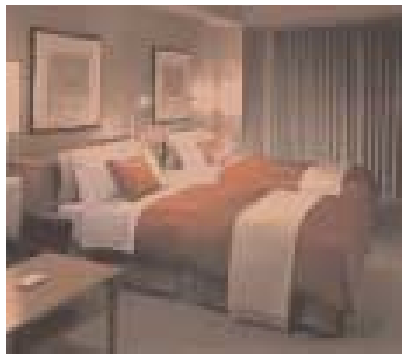

Ilustração 16: Apartamento do Hotel Shiodome no Japão- modelo 1. Fonte: TRIPADVISOR, 2007.

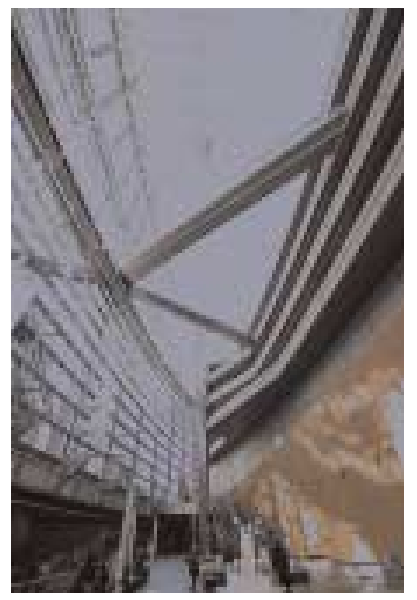

Ilustração 19: Vista do Hall do Hotel.

Fonte: PANORAMIO, 2007

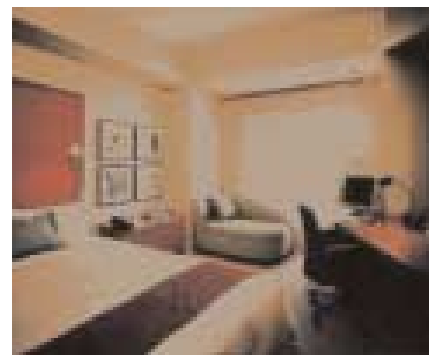

Ilustração 17: Apartamento do Hotel Shiodome no Japãomodelo 2 durante o dia. Fonte: TRAVELHERO, 2007.

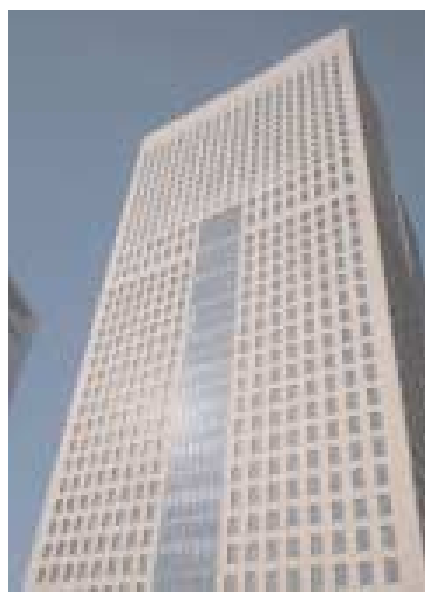

Ilustração 20: Vista do edifício Skiodome no Japão (hotel e escritório).

Fonte: WORLDGBC,2007.

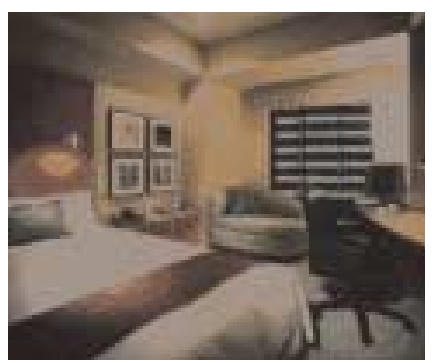

Ilustração 18: Apartamento do Hotel Shiodome no Japãomodelo 2 durante a noite. Fonte: TRAVELHERO, 2007.

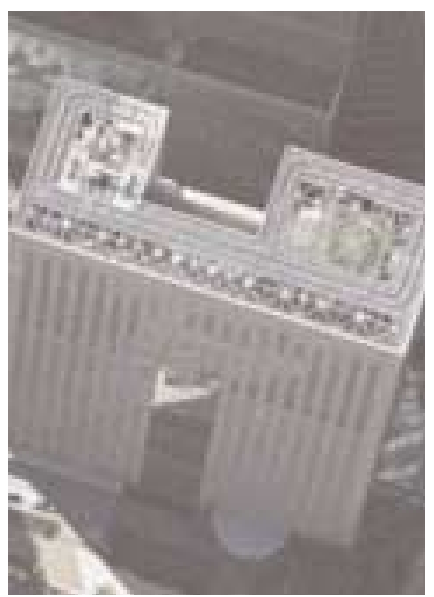

Ilustração 21: Vista aérea da Torre Shiodome com destaque para formato da planta tipo. Fonte: GOOGLE EARTH.,2007.

apartamentos, nas ILs. 16 e 17 respectivamente enquanto que, na IL. 18, a imagem apresenta o mesmo apartamento anterior no período noturno, com a veneziana fechada e apenas luz artificial. Merece destaque também a atenção especial dada no projeto de iluminação de cabeceira, que em muitos hotéis não atendem nem as exigências mínimas de conforto luminoso.

A vista do saguão do Hotel na IL. 19, a vista da fachada na IL. 20 e vista aérea na IL.21 mostram o quanto a arquitetura pode ser rica em soluções e prover qualidade do ambiente interno e bem estar das pessoas, sem deixar de lado a eficiência energética de um edifício.

Verificou-se que há uma tendência européia de aprimorar os apartamentos de acordo com as necessidades de uso dos hóspedes, tornando-os menos rebuscados em sua arquitetura exterior e interior e, ao mesmo tempo, mais práticos e 
funcionais.

O exemplo de edifício de uso misto com escritório e hotel, assim como existe no Japão, já é uma realidade no Brasil, mais precisamente em São Paulo, no bairro de Moema, cuja operação vem sendo feita por uma rede hoteleira internacional. Acredita-se que esta deva ser a tendência de ocupação dos próximos edifícios, mas que o exemplo da torre Shiodome deve ser visto como uma referência pelas inovações tecnológicas, e com isto, atender as condições de conforto e eficiência energética do edifício.

O clima de São Paulo e as características construtivas dos edifícios do setor hoteleiro econômico refletem a grande importância que a determinação dos parâmetros arquitetônicos exerce na obtenção de edifícios de hotéis mais confortáveis aos seus usuários e mais eficientes energeticamente. 


\section{O hotel econômico}

O hotel econômico caracteriza-se por ser um empreendimento com intenso custo de mão de obra, sendo este proporcional ao número de UH. Os serviços de hospedagem são oferecidos de forma ininterrupta, o que implica na necessidade de funcionamento permanente da maior parte dos departamentos e setores de atendimento aos hóspedes.

Os hotéis de categoria econômica oferecem tarifas reduzidas em função da redução dos custos de instalações e serviços, que devem oferecer o mínimo essencial ao hóspede a que se destinam, sem prejudicar a qualidade exigida por ele. Segundo o guia imobiliário da Revista Veja (2006), visto que os hotéis econômicos trabalham com margens pequenas de lucro, eles têm de funcionar com uma ocupação de aproximadamente $75 \%$ para serem rentáveis - número bem acima da média em São Paulo para as outras categorias,que é de 51\%.

Dessa forma, contam com uma taxa de ocupação alta e baixo custo operacional, para que o prazo de amortização do investimento seja o menor possível. A padronização de processos construtivos ou a implantação de tecnologias avançadas na construção, dentro da categoria de hotéis econômicos, podem não oferecer nenhum diferencial para um mercado tão competitivo como o de hotéis.

O maior diferencial entre esses hotéis são as UH, como se pode observar no trecho que segue: 
Os apartamentos constituem o produto mais perecível do hotel, que representa a sua maior fonte de renda. Cada detalhe deve merecer atenção especial, para que seu planejamento físico visualize facilidades em operações de limpeza, manutenção e tranqüilidade do hóspede (CADERNOS BRASILEIROS DE ARQUUITETURA, 1997).

O hóspede executivo é uma categoria de usuário da rede hoteleira que merece destaque. Trata-se de funcionários ou representantes de empresas que estão em viagens de negócios, normalmente financiadas pelas próprias empresas. Dessa forma, os hotéis voltados para essa modalidade de hóspede estão freqüentemente localizados estratégicamente na cidade, próximos a pavilhões e centros de convenções e em locais de fácil acesso, desse modo atendendo melhor ao hóspede interessado nas feiras de eventos.

A maioria dos hotéis econômicos mantém algumas características arquitetônicas predominantes, dentre as quais destacam-se: apartamentos frente a frente com um corredor central e dimensões pré-determinadas pelas redes hoteleiras que baseiam o projeto do apartamento em si em manuais de arquitetura com as diretrizes de projeto fundamentais e a disposição do lay-out). As operadoras internacionais adotam diferentes medidas na concepção inicial de seus hotéis econômicos, para que estes incorporem a racionalidade nos seus processos construtivos, com o maior aproveitamento dos recursos naturais, mantendo o nível de conforto e os equipamentos de acordo com a categoria do hotel.

A construção de um hotel é encarada como uma linha de montagem de componentes industriais, não somente no que tange aos elementos estruturais como também aos elementos de vedação integrados aos novos processos de instalações hidráulicas, elétricas e de automação, que cada vez mais vêm substituindo os processos tradicionais de construção.

Segundo entrevista informal, realizada em 2006 com engenheiro de projeto de uma rede internacional de Hotéis, Engenheiro Carlos Martins, o que mais onera uma obra é a falta de conhecimento do investidor com a fase operacional de um hotel que não leva em conta o ciclo de vida e os parâmetros decisivos para a redução do custo de operação e manutenção. Esta rede domina mais de $70 \%$ do mercado hoteleiro na cidade de São Paulo, e é o segundo no ranking do setor Hoteleiro do Brasil tanto em números de empreendimentos quanto em apartamentos (SALANI, 2007). Na IL. 22, aparecem alguns hotéis dessa rede cujos projetos seguem normas rigidamente pré-determinadas, além de uma listagem de fornecedores previamente aprovada. Eles obedecem ao mesmo sistema da mesma 

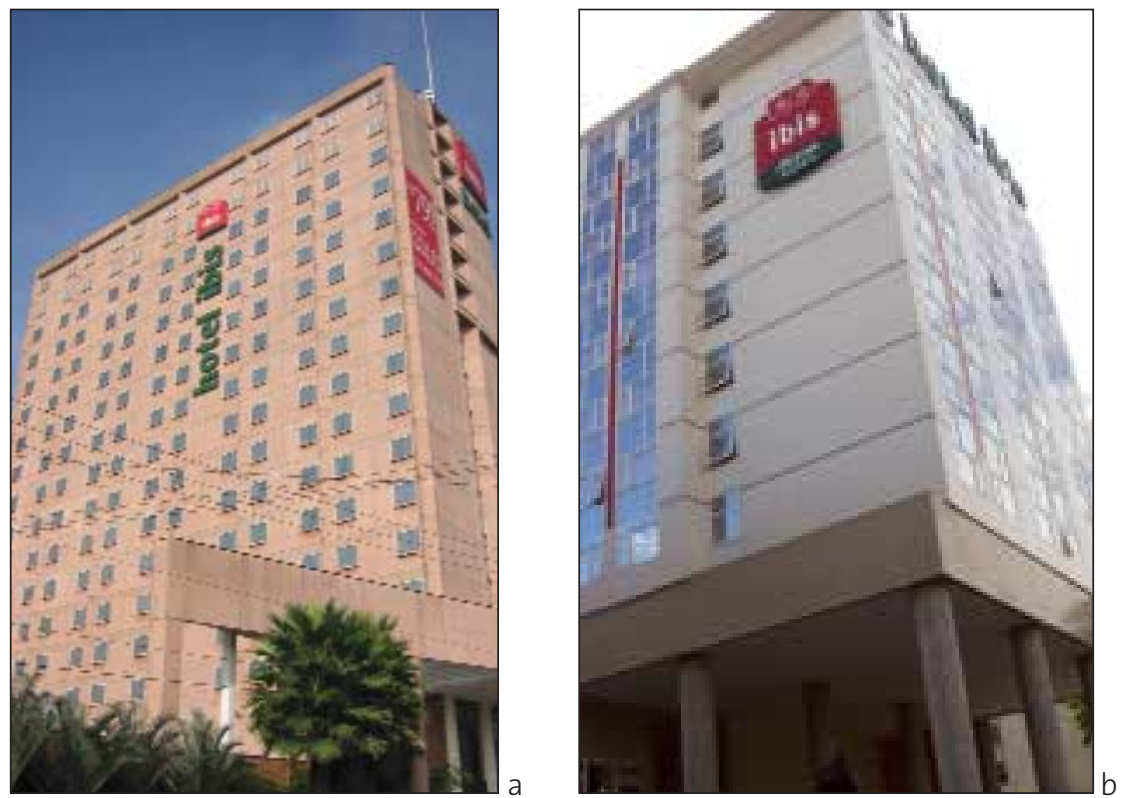

Ilustração 22: Hotel Íbis Casa Verde (a) e Íbis Santos Dumont (b): rede Accor.

rede, onde se notam algumas diferenciações no revestimento da fachada externa. No entanto, são mantidas a forma retangular dos edifícios e a porcentagem de abertura por área de Fachada (WWR), abaixo de 0,4.

Além disso, nesses mesmos hotéis, os apartamentos continuam universais, seguindo o mesmo padrão de dimensionamento e arquitetura, mesmo acabamento interno e mobiliário, incluindo até mesmo a decoração interna.

\subsection{Crescimento do setor hoteleiro}

O desenvolvimento dos centros urbanos das principais capitais brasileiras foi analisado por Jacob (2006) e referencia o surgimento dos hotéis ao longo dos anos como fator indutor de crescimento urbano e de desenvolvimento imobiliário, indicando assim tendências de crescimento e desenvolvimento na região onde estes estão inseridos (ver IL. 23).

Nesse mesmo estudo, o autor fornece uma cronologia, para o caso da cidade de São Paulo, o surgimento dos hotéis ao longo do século XX, desde o Grande Hotel, no século XIX, passando pelo Hotel Esplanada, de 1923 (na esplanada do Vale do Anhangabaú), o Hotel Excelsior, do arquiteto Rino Levi, localizado na Avenida Ipiranga (e que acompanhou o processo de verticalização da cidade), chegando enfim às duas 

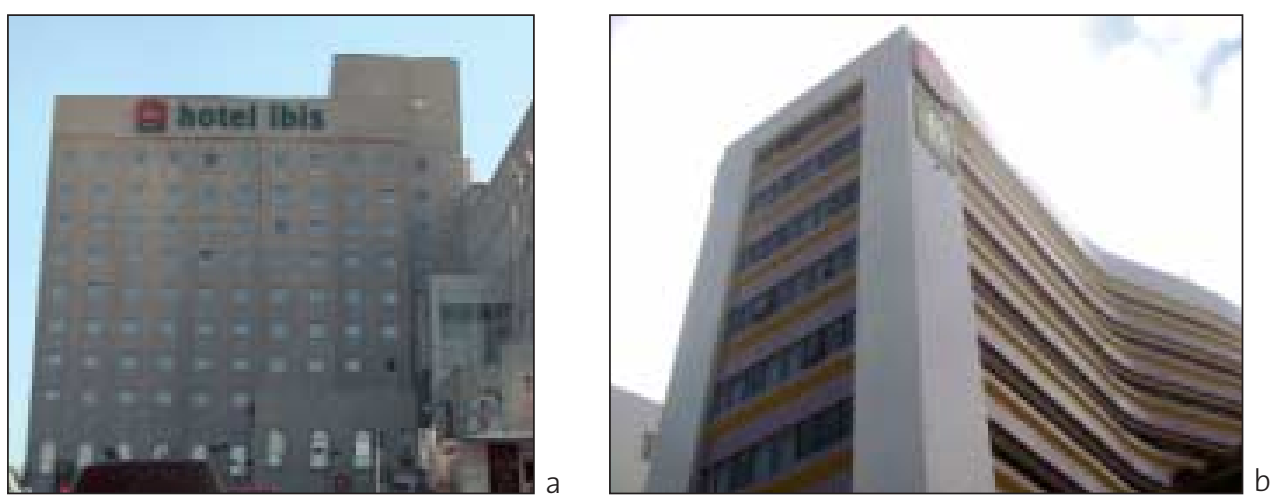

Ilustração 23: Grupo Accor: Hotel Ibis Interlagos, São Paulo (a), Hotel Ibis Maceió (b), Alagoas.

últimas décadas, período no qual a cidade passou por intensas modificações.

Dos anos 1950 até a década de 1970, o número de hotéis na cidade passou de 10 para 48 (AMUNSEN, ROCHA e MELLO JUNIOR, 2002, apud JACOB, 2006). Na década de 1980, o eixo comercial ampliou-se da região central e Avenida Paulista para a região da chácara Santo Antônio. Nessa mesma época, surgiram o Hotel Maksoud Plaza (1980), na região da Avenida Paulista, e posteriormente o Hotel Transamérica (1986), na região da Chácara Santo Antônio, ambos hotéis de luxo e ainda hoje em funcionamento.

Recentemente, no novo eixo comercial da Avenida Faria Lima e Avenida Luís Carlos Berrini, surgiram novos hotéis, destacando-se o Grand Hyatt e o Hilton (ambos de categoria luxo), e inúmeros hotéis econômicos e flats que atendem ao mercado de executivos em visita de trabalho à cidade. A evolução da expansão dos hotéis na cidade de São Paulo pode ser verificada na seqüência de mapas da cidade que apresentam a evolução do número de hotéis instalados, e sua distribuição nas regiões da cidade desde antes da década de 1970, até 2005 (SPOLON, 2006).

A evolução dos hotéis desde a década de 70 podem ser vistas nas ILs. 24, 25 e 26 , sequencialmente.

Atualmente a diversificação dos centros comerciais e do setor de eventos criou novos pólos que, anteriormente, eram regiões residenciais. Esses pólos têm crescido vertiginosamente, criando várias regiões com uso mais diversificado, com comércio e eventos bem desenvolvidos, e conseqüentemente interessantes economicamente para a cidade. Entre elas, podemos citar o Itaim, Moema e Pinheiros. 

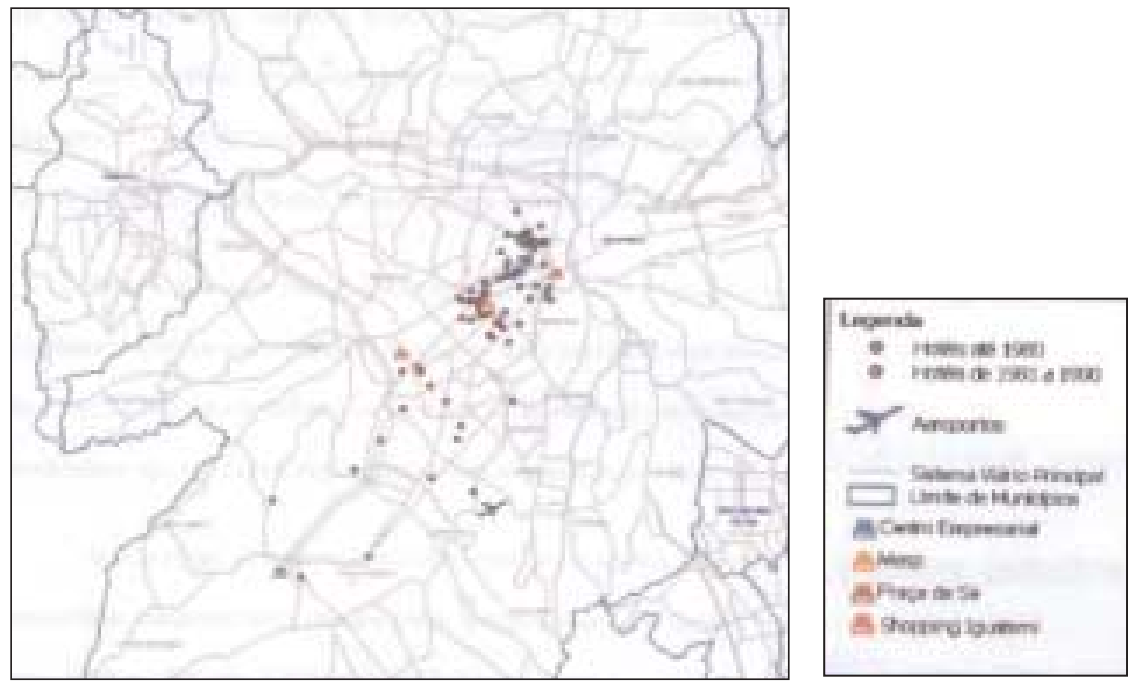

Ilustração 24: Mapa da implantação dos hotéis nas décadas de 70 e 80. Fonte: SPOLON, 2006
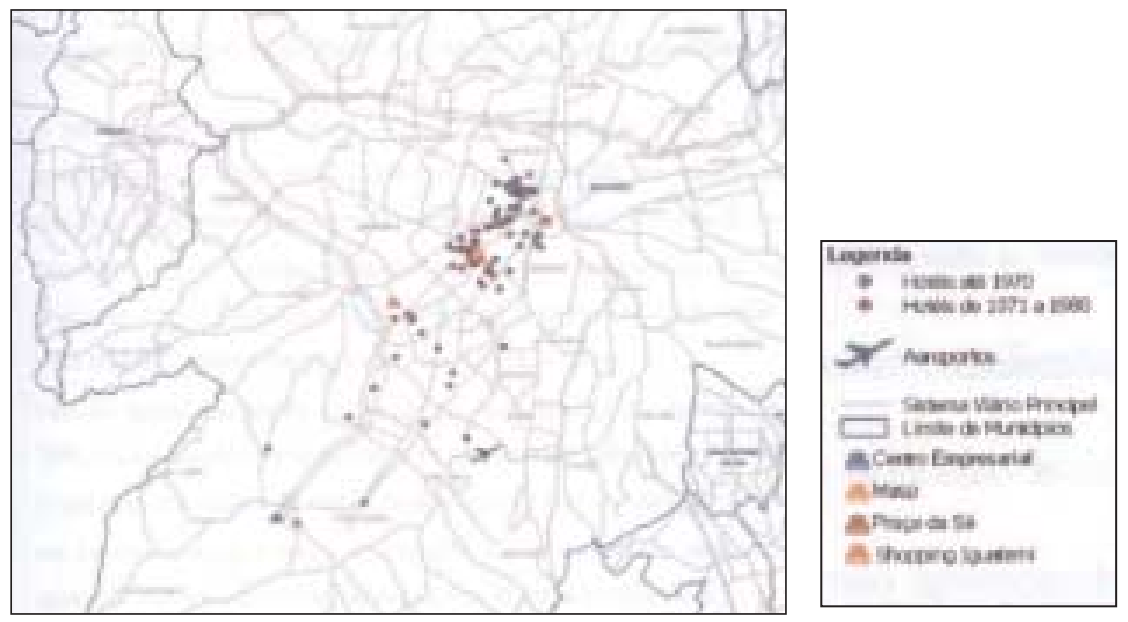

Ilustração 25: Mapa da implantação dos hotéis nas décadas de 90. Fonte: SPOLON, 2006.
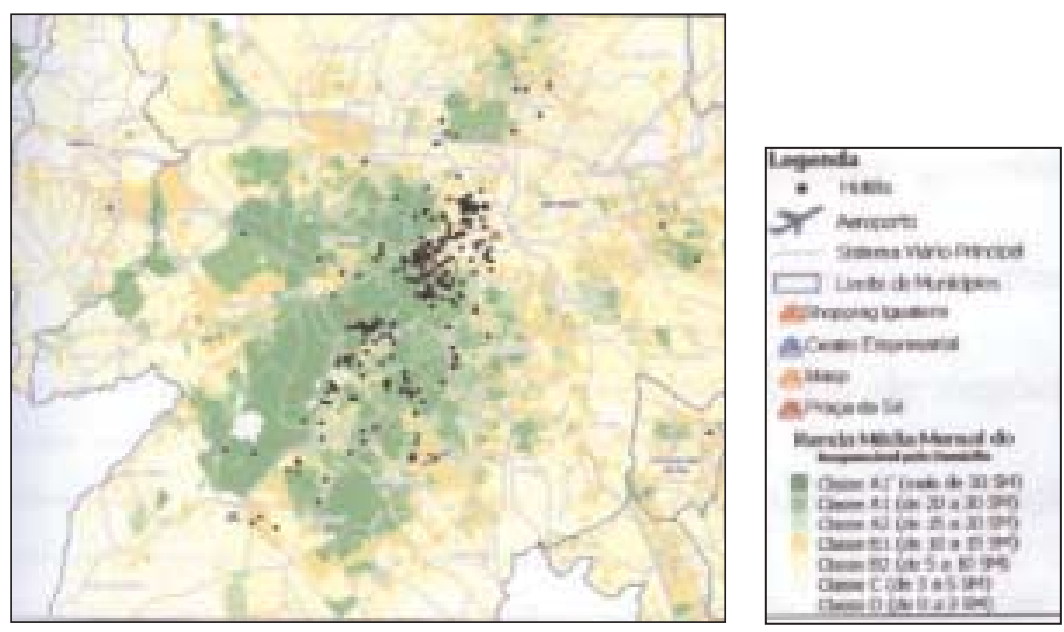

Ilustração 26: Mapa de renda e distribuição dos meios de hospedagem em São Paulo em 2005. Fonte: SPOLON, 2006. 


\subsubsection{O projeto do empreendimento como estratégia de mercado}

O desempenho e o sucesso de um empreendimento hoteleiro é fruto de avaliações preliminares que se baseiam na localização do empreendimento, passando pela definição da categoria do hotel (que determina as dimensões das UH), até chegar a estabelecer qual seria a qualidade dos serviços a serem prestados no empreendimento.

Diversos estudos, tais como Buoro et. al (2003), Mesquita, (2006), Weise e Carioni (2006), entre outros, apresentam a localização como um requisito fundamental (se não o primeiro em escala de importância) para um hotel, requisito este apontado tanto pelos hóspedes quanto pelo mercado imobiliário. Moreira (2001, apud WEISE e CARIONI, 2006) levantou os itens relevantes em uma avaliação, quando da análise de mercado de Hotéis e Motéis, a saber:

- Localização em bairros adequados;

- Disponibilidade de transporte por táxi, ônibus, bonde, metrô, trem e avião;

- Proximidade de rodovias;

- Concorrência das vizinhanças;

- Facilidade de acesso;

- Idade, tipo de construção e condições da concorrência.

O padrão de um hotel influencia diretamente o valor de sua diária e, esta, por sua vez, é determinada pelo sucesso do empreendimento, fruto direto da taxa de ocupação. A localização adequada de um hotel deve atender ao público a que este se propôs em sua concepção inicial, para que as taxas de ocupação sejam sempre adequadas ao padrão do hotel.

Os elementos acima apresentados possuem vínculo direto com a escolha do terreno mais adequado para um hotel, já que é este que determina a localização do bairro, a disponibilidade de transportes e assim por diante. Uma vez definido o terreno, segundo os itens destacados acima, o empreendimento, tem chances de ser bem sucedido.

O hotel, por sua vez, também é fruto direto do projeto arquitetônico do aprimoramento das estratégias (que podem reduzir as despesas operacionais, com o uso de sistemas passivos de conforto ambiental) e das estratégias de marketing (capazes de incentivar o aumento das taxas de ocupação), resultando assim em maior receita operacional líquida para o empreendimento.

Dentre as inúmeras estratégias comumente utilizadas por todas as grandes redes de hotéis, as que determinam metas de eficiência e desempenho na fase operacional são também reconhecidas pela certificação internacional da ABNT 
NBR, a ISO 9001 (norma que estabelece requisitos para o sistema de gestão da qualidade - SGO) e da ISO14001 (norma que define os requisitos para estabelecer um sistema de gestão ambiental - SGA).

\subsection{O projeto do hotel econômico}

O projeto de cada hotel busca minimizar os investimentos necessários para adequá-lo ao programa estabelecido pelo estudo de viabilidade. As redes hoteleiras trabalham com seu gerenciamento, a fim de articular os espaços e ambientes interna e externamente, visando sempre o funcionamento e a racionalização de áreas.

O gerenciamento dos Hotéis é realizado não apenas pelo próprio gerente de cada hotel, mas também pela rede hoteleira. A rede hoteleira opera os hotéis que ela mesma constrói ou apenas gerencia outros que foram construídos segundo as suas determinações. Estas determinações vão desde elementos arquitetônicos, pré-dimensionamentos das $U H$, detalhes de mobiliário, até mesmo as alternativas de SAC.

A preocupação deles é mesmo o gerenciamento energético de todos os seus hotéis, sendo que cada um, de acordo com sua categoria, tem que cumprir metas anuais de redução de consumo de energia, água e gás. Muitas vezes, dependendo dos resultados, a rede recomenda alterações para o hotel. Estas alterações podem ser superficiais, como troca de lâmpadas incandescentes por lâmpadas mais econômicas, ou podem ser mais trabalhosas, como a adaptação de novos equipamentos ao SAC, por exemplo, que melhoram o seu desempenho, e aproveitam do calor gerado por eles para esquentar a água dos chuveiros.

Nesse sentido, o projeto de arquitetura exerce papel fundamental para que todos estes elementos integrem-se da melhor forma possivel, atendendo também as necessidades operacionais desta tipologia.

\subsubsection{Objetivos operacionais}

A concepção do projeto arquitetônico de um hotel econômico deve ocorrer de forma integrada, para que haja um ganho de qualidade técnica para o conjunto. Do ponto de vista econômico-financeiro, essa integração favorece a redução do cronograma de obras, tornando o empreendimento menos oneroso. 


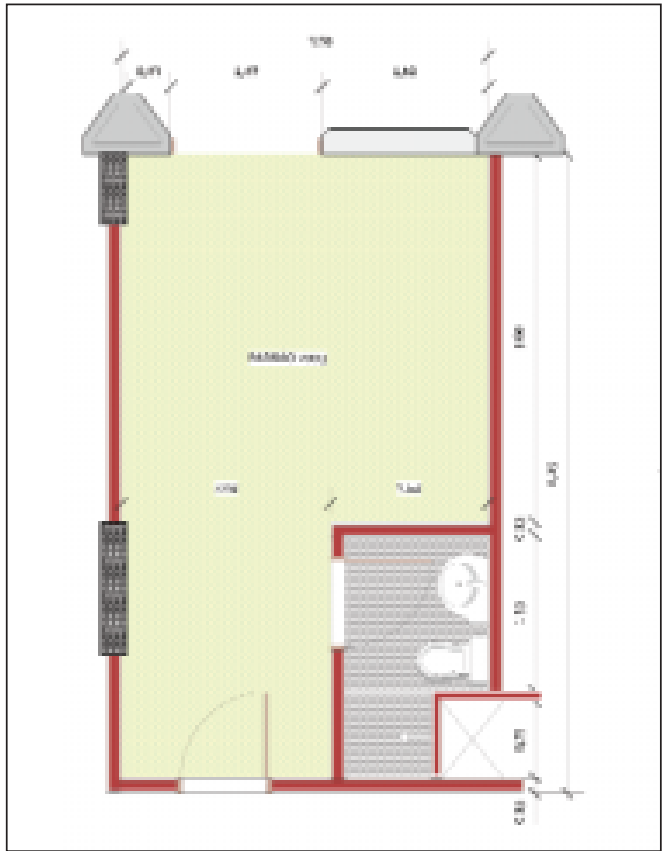

Ilustração 27: Planta Hotel Ibis - ano de 2003.

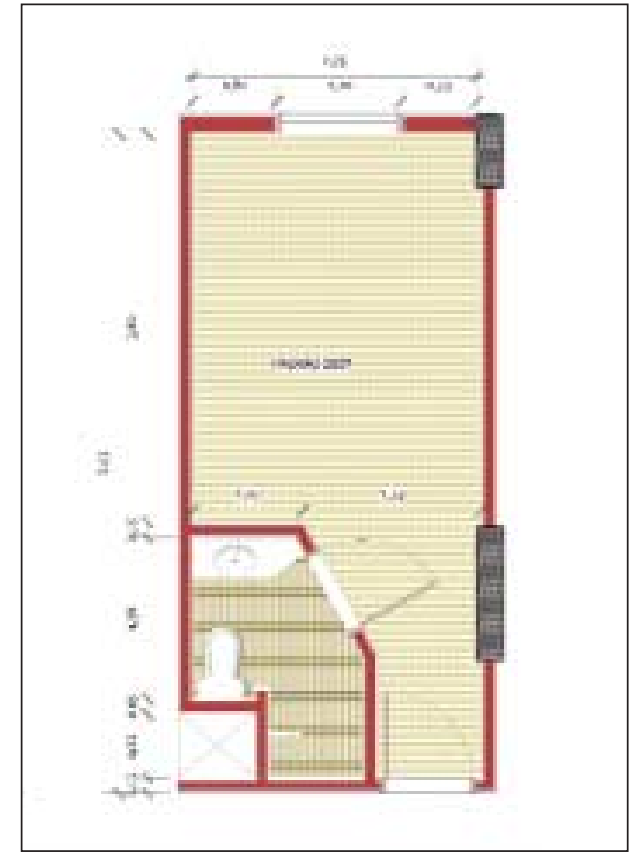

Ilustração 28: Planta Hotel Ibis - ano de 2007.

No planejamento do sistema de gestão de qualidade (SGO) dos hotéis econômicos, as redes hoteleiras seguem normas pré-definidas pelo grupo que vão do dimensionamento dos ambientes até a definição dos equipamentos a serem utilizados. Neste último caso, as soluções incluem desde a racionalização de água, o dimensionamento adequado e a escolha do sistema de ar-condicionado mais eficiente, seu mecanismo de automação (se necessário), até o gerenciamento da energia do edifício como um todo, para verificar se ainda há nele pontos a serem aprimorados. Seguindo essa exigência, as redes buscam sempre melhorar o seu elemento de atração principal: o apartamento padrão ou Unidade Habitacional (UH). Na ILs. 27 e 28 em diferentes hotéis da rede, e mesma bandeira (íbis), as UH sofreram algumas modificações, não apenas nas dimensões e materiais de acabamento, mas também no lay-out, mobiliário e até no sistema de iluminação.

O Íbis Piracicaba foi construído uma década depois do Íbis Expo (este inaugurado em 2002) e, desde essa época, nota-se que já houve uma alteração significativa no apartamento: disposição da bancada, largura e profundidade, sendo que, no último caso, as janelas não abrem, o que não ocorre no primeiro.

Em todos os hotéis da rede Íbis, cuja proprietária e operadora é a rede Accor, é feita uma auditoria semestral de manutenção, enquanto que nas franquias em que a Accor opera o empreendimento, essa auditoria ocorre uma vez por ano. Essa medida salienta ainda mais a preocupação do grupo, no caso a Accor, com a 


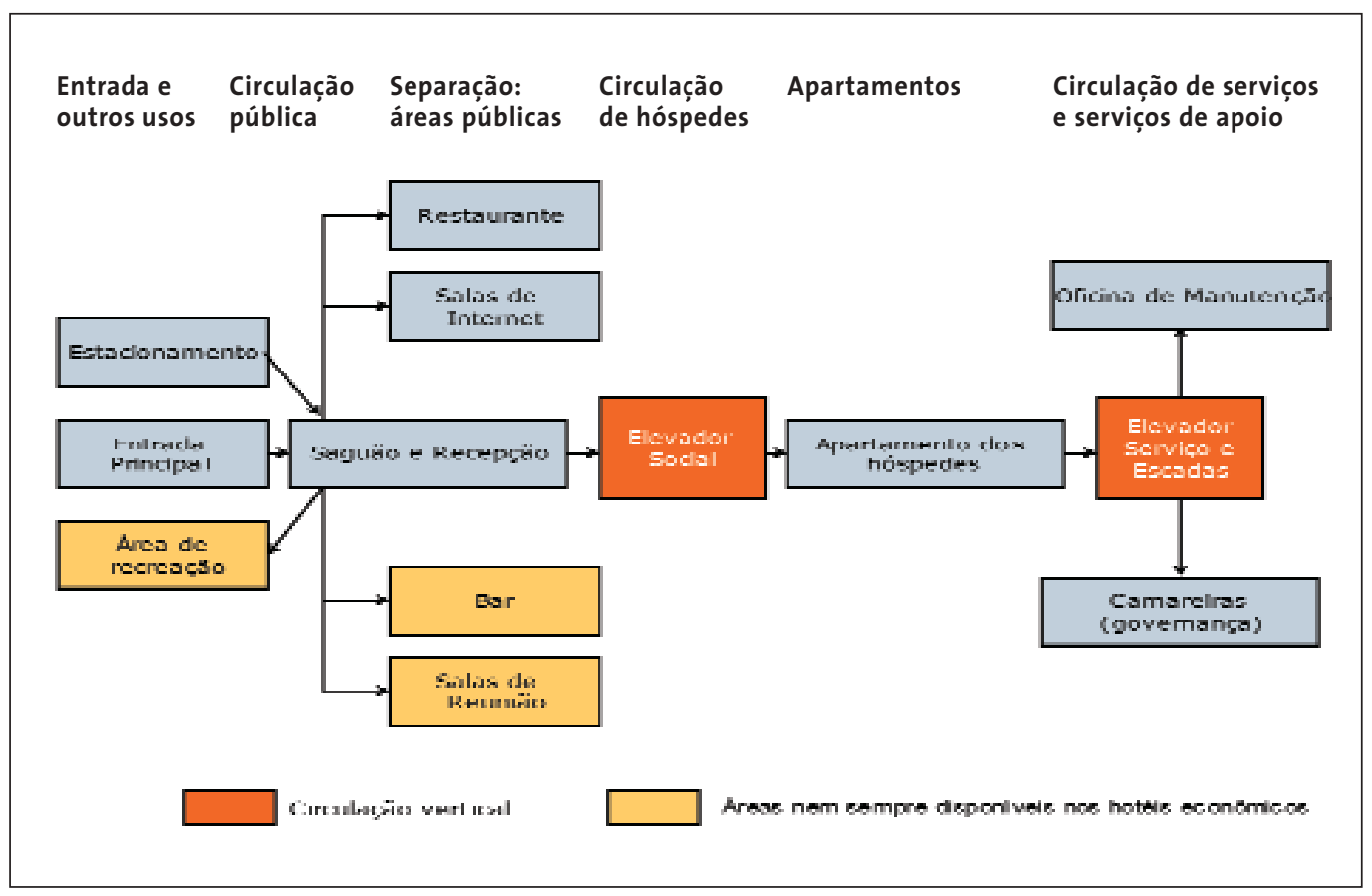

Ilustração 29: Inter-relações espaciais básicas do setor de hóspedes Fonte: CADERNO BRASILEIRO DE ARQUUITETURA, 1997, Adaptação da autora.

gestão operacional e a definição dos fornecedores e materiais do hotel. O impacto do projeto de arquitetura e da definição de alguns equipamentos no custo operacional do hotel determina o uso e a manutenção do edifício, servindo como subsidio para as alterações de projeto que são incorporadas aos novos hotéis da rede no país.

\subsubsection{Dimensionamento dos espaços}

A grande complexidade logística e necessidades diversas dentro de um hotel exigem do arquiteto um pré-dimensionamento para que os espaços cumpram as necessidades do uso com o devido conforto e eficiência. A inter-relação básica do setor de hóspedes, de acordo com o Caderno Brasileiro de Arquitetura (1997) deve estar conforme apresentado na IL. 29.

Diversos autores, com o objetivo de estimar as dimensões necessárias em cada ambiente e a área construída do empreendimento, criaram métodos baseados em estudos estatísticos de hotéis internacionais.

Nos hotéis econômicos, o total das UH representa 80\% ou mais da área total construída do empreendimento, enquanto que nos hotéis de nível médio esse valor é reduzindo para $75 \%$ da área total. Devido à grande complexidade de 


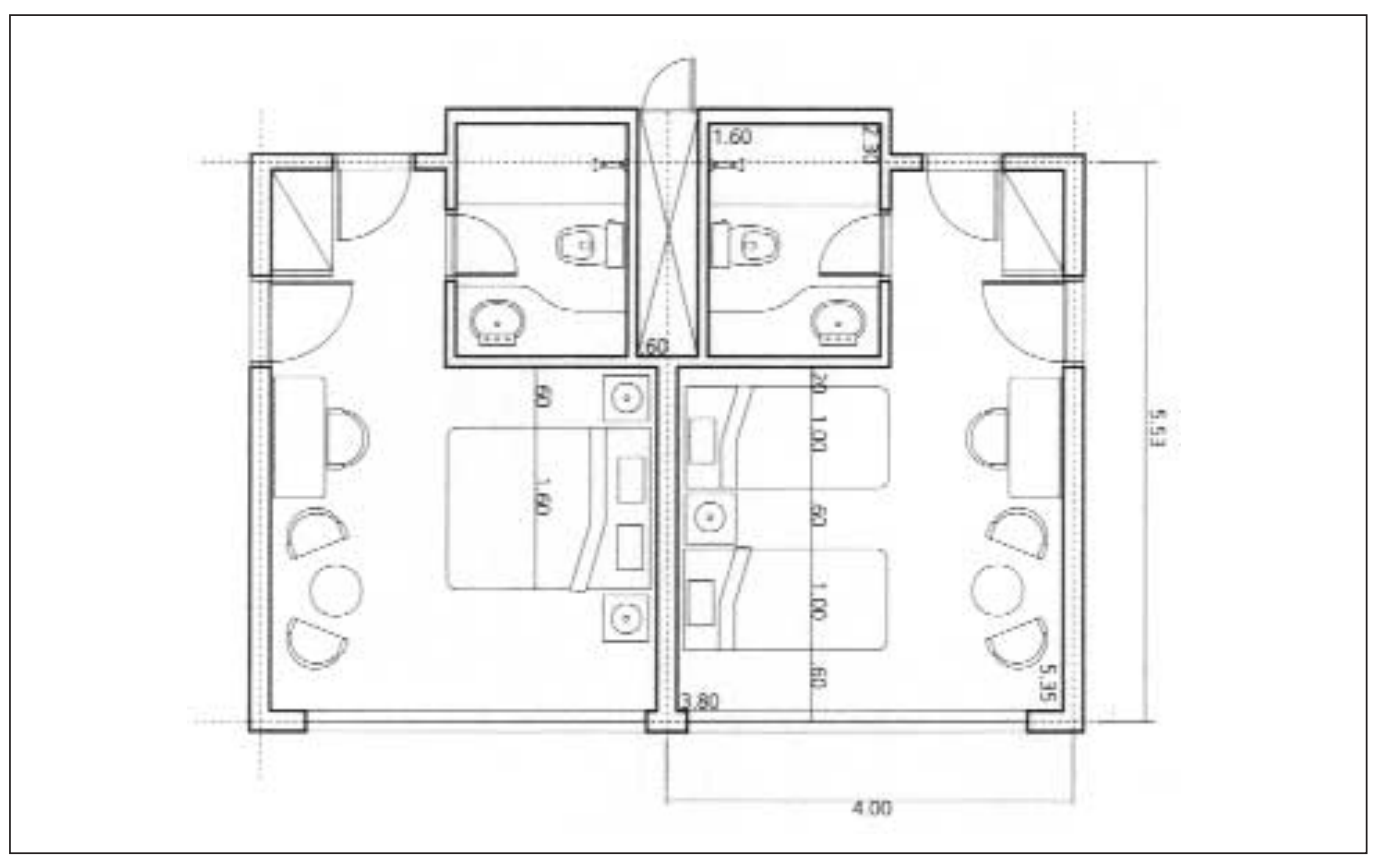

Ilustração 30: Exemplo das dimensões das UH dos Hotéis Econômicos.

Fonte: ANDRADE, BRITO E JORGE, 2002.

funções, neste trabalho priorizaram-se os estudos das UH. Na IL. 30, figura um exemplo das dimensões de um apartamento de hotel econômico, segundo Andrade, Brito e Jorge, (2002).

Outro autor, o arquiteto e professor de hotelaria Davi Lord Tuch, selecionou cerca de dois mil hotéis construídos a partir da década de 50, compostos por 100 a 600 UH (TUCH, 1980) e estimou as seguintes áreas, conforme listadas na TAB. 4.

Lawson (1995), em seu guia para desenvolvimento de hotéis e resorts americanos e europeus, baseou-se em sua experiência profissional e nas estimativas feitas durante consultorias e estudos desenvolvidos por ele para chegar ao dimensionamento, seguindo cada categoria do Hotel, conforme indica a TAB. 5 .

Para o mesmo autor, a área mínima da UH para cada padrão de hotel segue as áreas indicadas na TAB. 6.

Os hotéis econômicos, como foi mencionado anteriormente, são o produto mais racional de uma rede e, portanto, aliam o menor custo a uma qualidade considerada boa pelos próprios clientes (BUORO et. al, 2003). Algumas das instalações dos hotéis dessa categoria que são racionalizadas e aprovadas pelos clientes, podem se tornar referência também para as categorias superiores como turismo, superior, luxo e super luxo. 


\section{TABELA 4: CLASSIFICAÇÃO DO HOTEL SEGUNDO A ÁREA DA UH}

\begin{tabular}{|ll|}
\hline Categoria & Área por UH \\
\hline 1 estrela & $15,0 \mathrm{~m}^{2}$ \\
\hline 2 estrelas & $18,0 \mathrm{~m}^{2}$ \\
\hline 3 estrelas & $22,5 \mathrm{~m}^{2}$ \\
\hline
\end{tabular}

Fonte: TUCH, 1980.

TABELA 5: ÁREAS DAS UH PARA AS

CATEGORIAS DE HOTÉIS - EUROPEUS E AMERICANOS

\begin{tabular}{|c|c|c|c|}
\hline Europeus & $\mathrm{m}^{2}$ & Americanos & $\mathrm{m}^{2}$ \\
\hline Econômico & 21,7 & Econômico & 21,3 \\
\hline Médio & 25,2 & Médio & 28,9 \\
\hline Alto padrão & 27,4 a 30,0 & Alto padrão & 31,3 a 33,8 \\
\hline Luxuoso & 34,0 a 36,0 & Luxuoso & 35,1 а 36,2 \\
\hline
\end{tabular}

Fonte: LAWSON, 1995

TABELA 6: ÁREAS MÍNIMAS DAS UH PARA CADA CATEGORIA DE HOTEL

\begin{tabular}{|ll|}
\hline Categoria & Área por UH \\
\hline Econômico & $20,3 \mathrm{~m}^{2}$ \\
\hline Médio & $25,2 \mathrm{~m}^{2}$ \\
\hline Padrão & $33,9 \mathrm{~m}^{2}$ \\
\hline
\end{tabular}

Fonte: LAWSON, 1995. 


\subsubsection{Os sistemas de ar condicionado (SAC)}

De todas as instalações existentes em um hotel econômico, pode-se dizer que o ar-condicionado será, se não a de maior impacto, uma das instalações de maior impacto, tanto para o usuário-hóspede, quando para o proprietário do empreendimento.

Em pesquisa realizada pelo Balanço energético Nacional (BEN) em 2007, foram levantados o precentual de empresas que dispõem de SAC ou outros sistemas de ventilação, conforme apresentado na IL. 31. A base de dados foi uma a mostra de 2700 empresas comerciais, não apenas em hotéis, sendo 100 unidades de cada concessionária de energia, considerando-se uma margem de erro de 3,1\%. Verificou-se que $77 \%$ das empresas possuem SAC diretos, ou seja, da parede ou split. Em segundo lugar, com 33\% das empresas, estão os sistemas de ventilação e exaustão, seguidos por $25 \%$ de SAc com roof top e self contained. Por último, com $16 \%$ estão os sistemas indiretos, de água gelada.

Neste mesmo estudo, foi feito um levantamento das empresas que possuem SAC, separadas por estabelecimentos comerciais e por regiões brasileiras. Verificouse que, na IL. 32, nos hotéis e motéis, 52,57\% dos estabelecimentos na região sudeste possuía SAC, enquanto que, em outros setores comerciais, estas porcentagens eram bem menores, tais como: Faculdade e Escolas (9,76\%); Servi-ços de Saúde (10,01\%); Bancos e Financeiras (8,19\%); Padarias (2,6\%) e Clubes e Associações (7,35\%).

Em se tratando de um dado em escala maior, com vários tipos de edifícios, em que os Hotéis foram avaliados juntamente com os motéis (apesar de ambos possuírem usos e forma de ocupação bastante distinta), nota-se que a representatividade do SAC no setor hoteleiro é significativa.

Segundo Correia (2007), 47\% do consumo por uso final do setor comercial foi devido à carga do SAC. Na região Sudeste, 52,57\% dos Hotéis possui ar condicionado, enquanto que, no Brasil inteiro, o percentual cai para 32,35\%.

Apesar da classificação de hotel econômico segundo os critérios da EMBRATUR apresentado na seção 2.2.3 não obrigar que essa categoria hoteleira tenha SAC, o mercado de hotéis, que vem sendo cada vez mais dominado pelas redes internacionais, desconsideram este fato. Eles buscam equalizar os padrões de UH em todo mundo, mantendo o SAC mesmo nas categorias simples como a econômica.

Em estudo detalhado do consumo de energia elétrica desagregado por usos finais, realizado em hotel de categoria econômica em São Paulo (BUORO, De BENEDETTO e MIURA, 2003) durante o mês de agosto de 2002, constatou-se que o SAC representou $70 \%$ do consumo mensal de energia elétrica. O hotel relacionado a esse mesmo estudo dependia totalmente do SAC, já que as janelas dos aparta- 


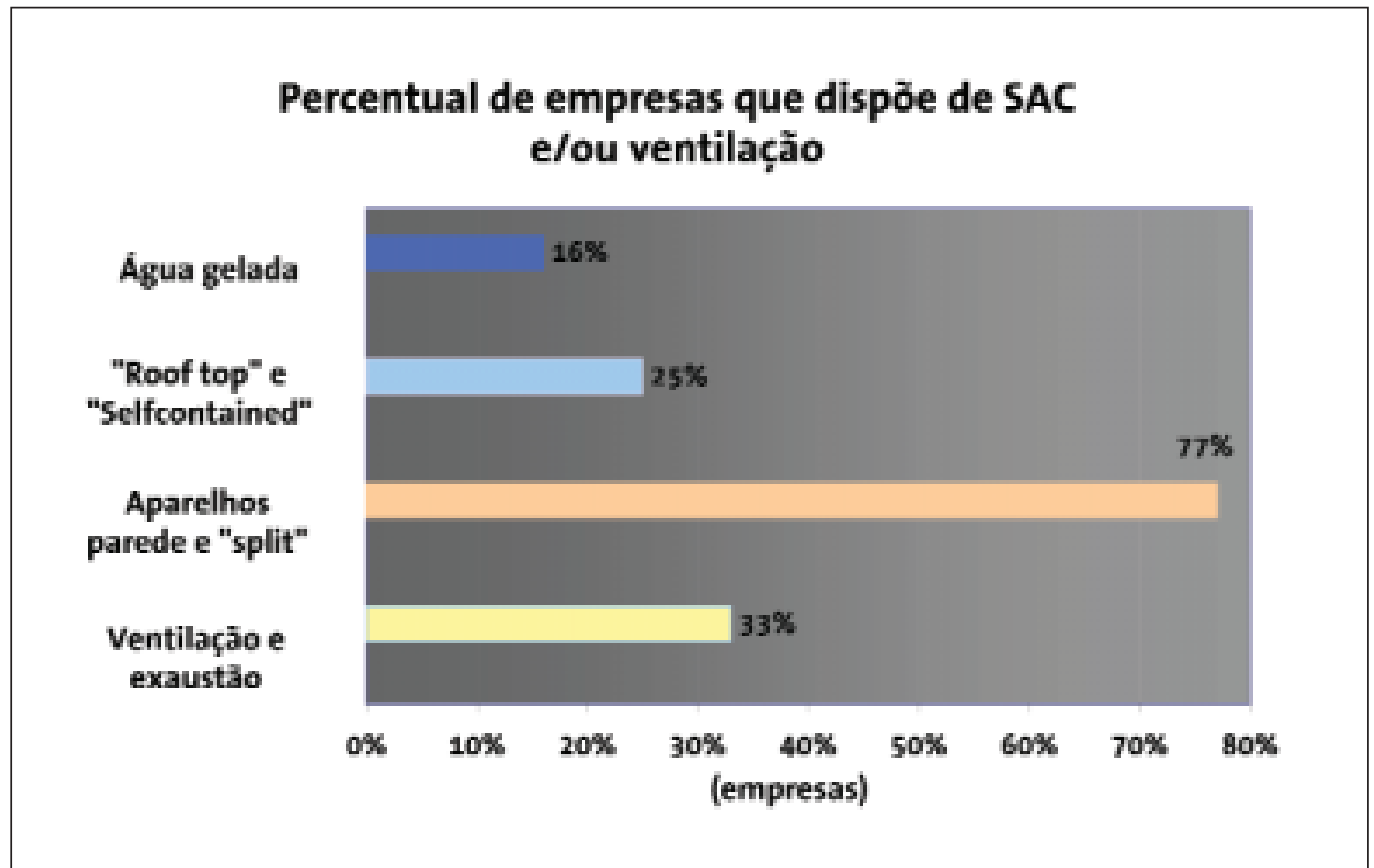

Ilustração 31: Percentual de empresas brasileiras do Setor Comercial que dispõem de sistemas de ar condicionado e/ou ventilação.

Fonte: SOUZA, 2007.

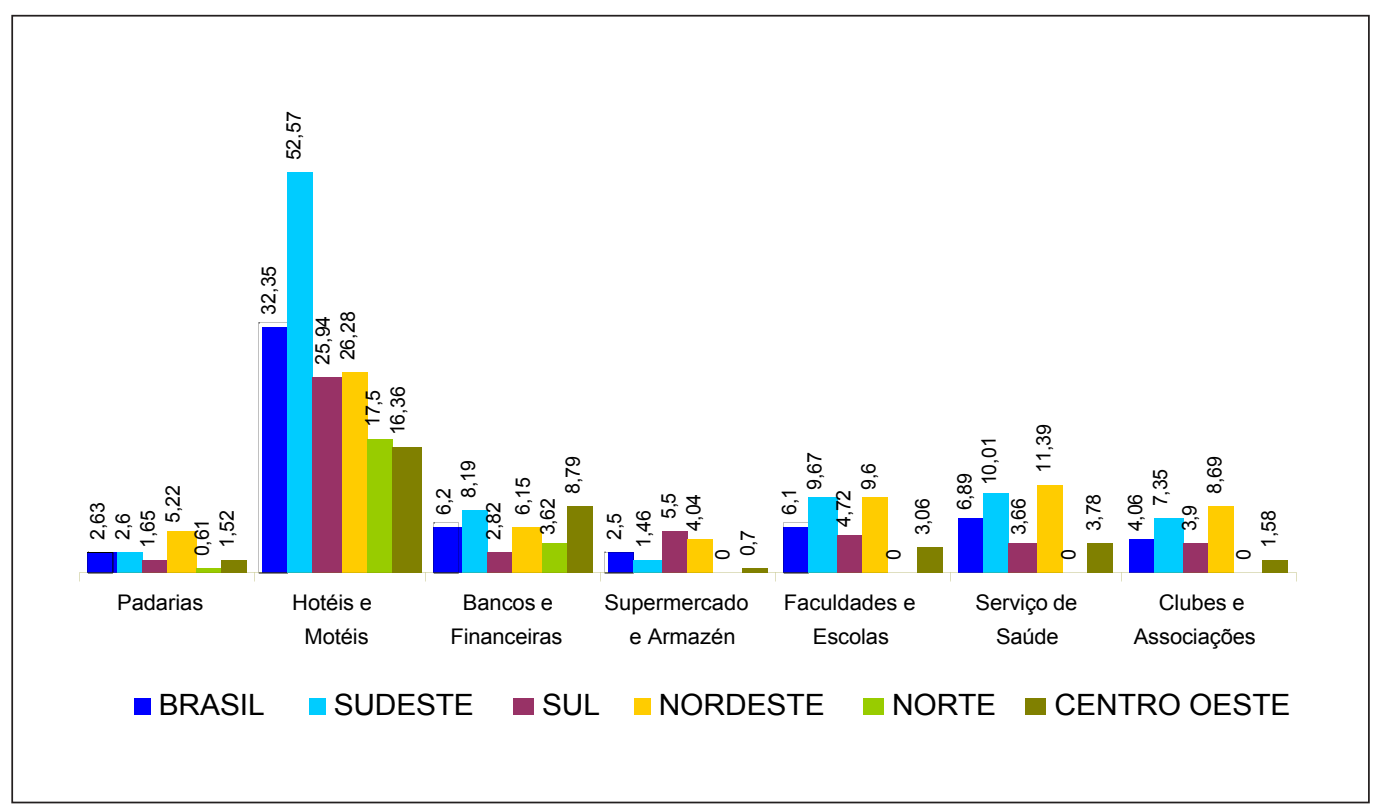

Ilustração 32: Porcentagem da posse média de ar condicionado no setor comercial no Brasil (por região).

Fonte: CORREIA, 2007. 


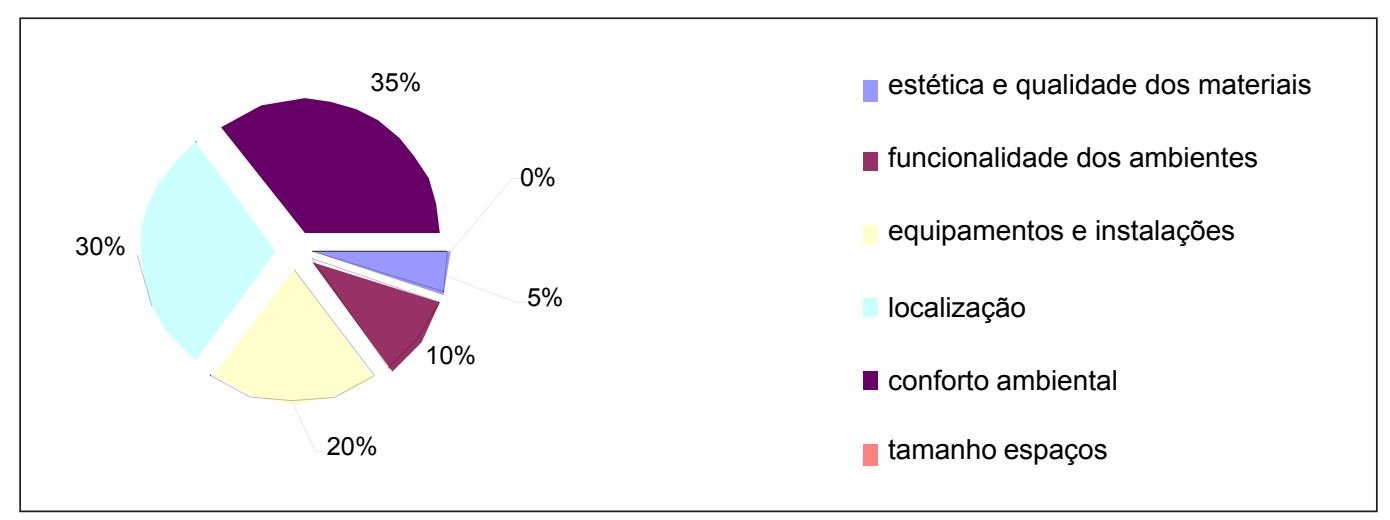

Ilustração 33: Requisito votado como indispensável em Hotel Econômico.

Fonte: BUORO, De BENEDETTO e MIURA, 2003.

mentos eram lacradas e a renovação e o resfriamento do ar ocorriam, exclusivamente, ou pela ventilação mecânica ou pelo sistema de ar condicionado. Sobre o mesmo edifício, foi realizada uma Avaliação Pós Ocupação (APO) que constatou que o conforto ambiental é o requisito considerado indispensável no hotel, representando $35 \%$ do total, conforme indica a IL. 33 .

\subsubsection{Diferencial das redes}

Da mesma forma que alguns autores criaram um método de dimensionamento dos hotéis, as grandes redes internacionais criaram seus próprios métodos. Na medida em que os arquitetos são selecionados para desenvolverem o projeto de um hotel, a operadora apresenta seu manual básico, juntamente com as exigências de cada bandeira e o pré-dimensionamento dos espaços mais padronizados, tais como a UH.

Nos grandes centros como São Paulo, isso termina por gerar projetos monótonos e desinteressantes, arquitetonicamente falando, com a mesma aparência e disposição de quartos.

A eficiência dos hotéis econômicos começa com a arquitetura, passando pelos tipos de serviços oferecidos e pelo número reduzido de funcionários para atender as necessidades básicas do hotel. A recepção e áreas administrativas são prioritariamente conjugadas e, em alguns casos, têm como anexos o bar e o restaurante. Isso faz com que se reduza o espaço de circulação horizontal, maximizando o aproveitamento das áreas comuns.

A altura do edifício resulta do estudo de viabilidade do empreendimento, do coeficiente de aproveitamento e da taxa de ocupação do terreno, consideran- 

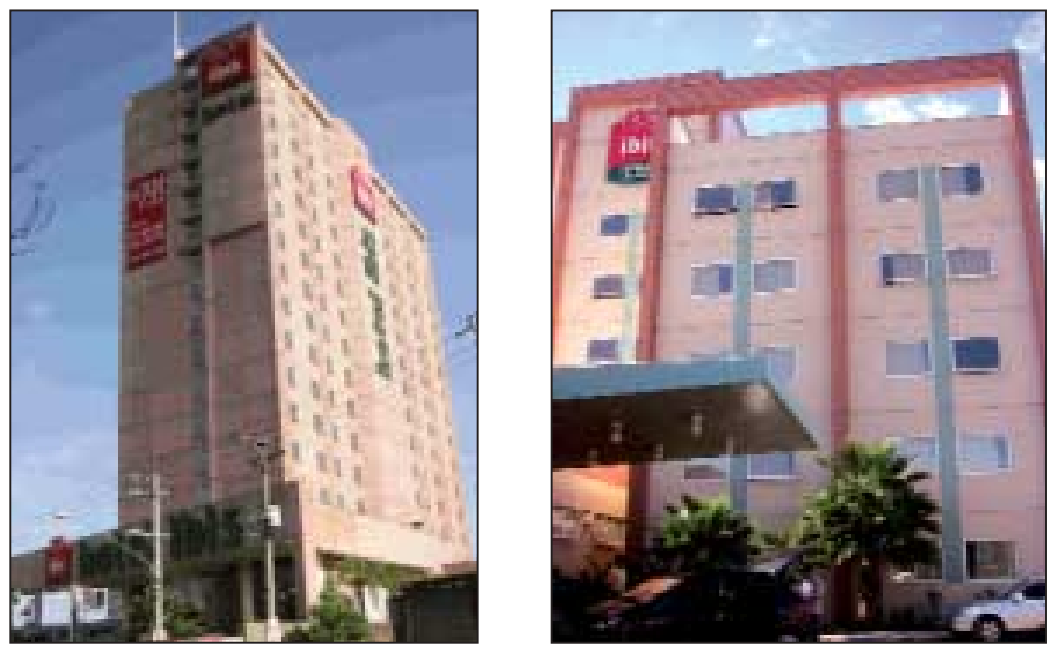

Ilustração 34: Hotel Íbis Expo - capital (a) com 12 andares e Ibis Piracicaba, interior (b), com 5 andares

do ainda a possibilidade de operação urbana, elemento que não está sendo avaliado aqui.

Considerando-se que este trabalho destina-se à uma caracterização mais específica para a cidade de São Paulo, o potencial construtivo do hotel tende a ser o maior possível, já que o valor imobiliário do terreno também o é (comparados com outras regiões do país, cujos terrenos em sua maioria são proporcionalmente maiores e o valor do metro quadrado é menor).

Na IL. 34, nota-se que, na capital de São Paulo, a tendência de uma rede é construir hotéis de grande porte, com torres de aproximadamente 12 andares, enquanto no interior a tendência é de edifícios mais baixos, dessa maneira economizando com os gastos com o consumo de energia proveniente do elevador, entre outros.

\subsubsection{Um exemplo de projeto de hotel econômico em São Paulo}

A UH, o mais importante elemento arquitetônico de um hotel econômico, é avaliada anualmente pela rede Accor-ĺbis, que desse modo busca aprimorar seu dimensionamento, melhorando tanto a planta como o desenho do mobiliário padrão do apartamento.

A IL. 35, mostra a planta do apartamento de um hotel de uma das maiores redes dos país: a Íbis.

Como está representado nas ILs. 27 e 28, a planta dos hotéis Íbis Interlagos e Piracicaba são idênticas, sendo ambas fruto da atualização e revisão da planta 


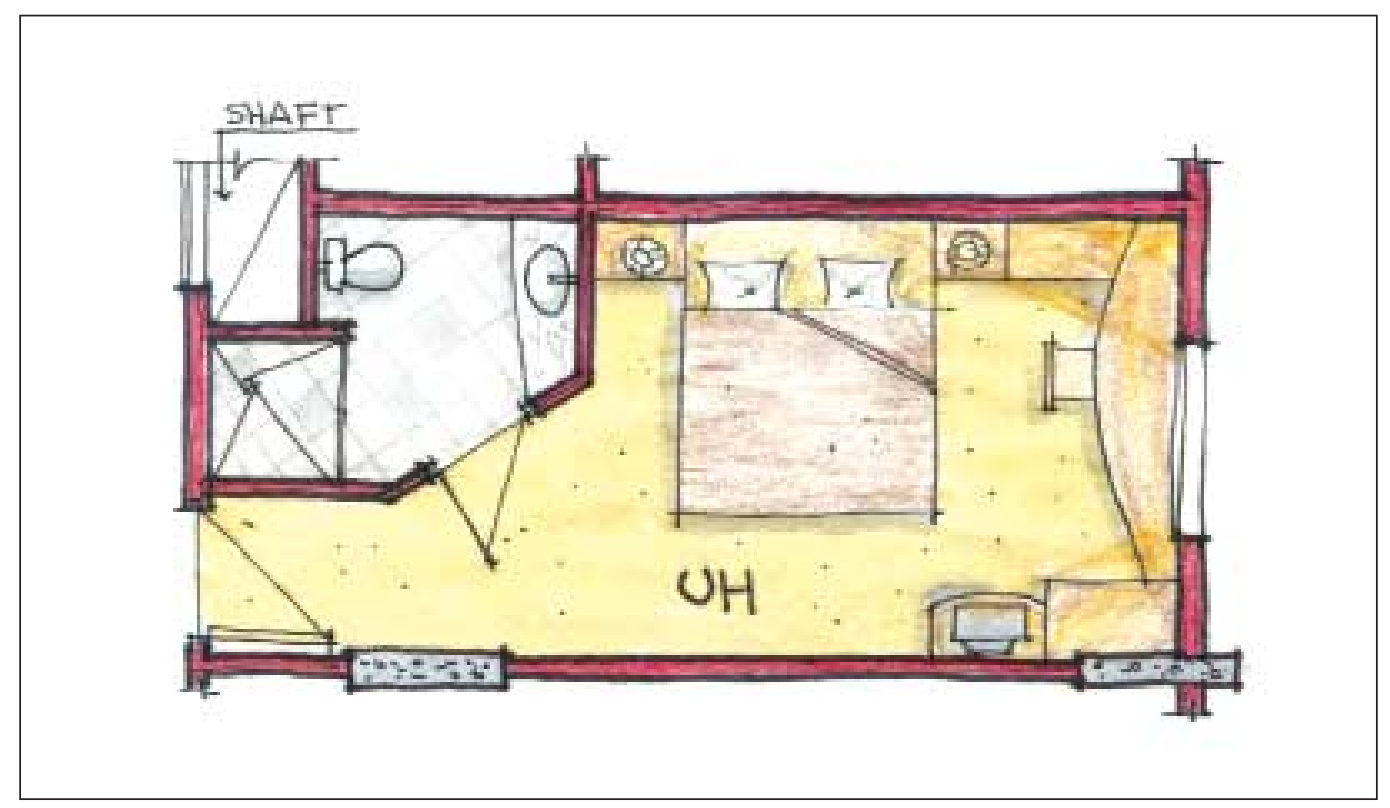

Ilustração 35: Planta Padrão do Hotel Íbis (2007).

do Íbis Expo, inaugurado em 2002. A unidade habitacional, portanto, teve seu tamanho reduzido, mantendo a qualidade oferecida anteriormente. Com essa alteração, reduziram-se também os custos de implantação e, ainda mais importante, de manutenção e consumo de energia com ar condicionado, por exemplo. Quanto menor o volume de ar de um ambiente, para as mesmas condições internas, menor a capacidade do sistema para resfriá-lo.

Durante estada, em Janeiro de 2008, no Hotel Ibis Santos Dumont (inaugurado em Outubro de 2007), no Rio de Janeiro, capital, verificou-se que já foram incorporados novos equipamentos, como a TV de plasma, que aumentam a área livre da UH, e reduzindo o consumo de energia. Outras alterações também foram feitas para facilitar a manutenção, como a instalação do fancolete externo, não mais embutido no forro, como os hotéis anteriores. Neste mesmo Hotel, o sistema de iluminação artificial inclui circuitos independentes, com a iluminação da cabeçeira mais adequada do que nos Hotéis visitados anteriormente.

Verificou-se que a tendência das redes é manter todos os seus empreendimentos sob constante auditoria, verificando meios de melhorar as condições de conforto, melhorando a eficiência nas dimensões dos espaços, a disposição do layout e, conseqüentemente, reduzindo os custos no contexto mais amplo. Nesse contexto, é fundamental que sejam bem definidos os parâmetros de projeto dos hotéis, para que o objetivo de eficiência no contexto mais geral seja atendido. 


\section{Um novo conceito de projeto de hotel econômico}

A adoção de estratégias bioclimáticas ${ }^{11}$ em um edifício pode ocorrer desde a concepção inicial do projeto de arquitetura até mesmo depois que o edifício já estiver operando em sua fase de uso. Neste período, o edifício deve atender a dois quesitos básicos: as necessidades de conforto dos usuários, e a eficiência energética, ou seja, o uso racional da energia elétrica.

A integração das estratégias de projeto, definidas de acordo com as condições climáticas do local e o programa de necessidades, deve atender à relação ótima entre o custo-benefício dos sistemas passivos (tais como iluminação e ventilação natural) e dos sistemas ativos (tais como iluminação artificial, sistemas de condicionamento artificiais, entre outros).

Evans (2007) apresentou um quadro comparativo entre os diversos estágios de projeto, qual o seu potencial de aplicação e o custo de aplicação das estratégias para cada um dos estágios, conforme apresentado na TAB. 7. Verifica-se, portanto, que quanto mais cedo forem aplicadas as estratégias bioclimáticas, maior o seu potencial de aplicação a baixo custo.

Na busca por uma avaliação de um projeto de hotel econômico como fundamentação para a proposta de projeto de Hotel econômico, foi feito um levantamento de dados empíricos em estudo de caso - Hotel de categoria Econômico de

11. A arquitetura bioclimática, baseia-se na correta aplicação de elementos arquitetônicos e tecnologias construtivas para consumir-se menos energia, otimizando o conforto de seus ocupantes. 
TABELA 7: ESTÁGIOS DO PROJETO COM POTENCIAL DE INTEGRAÇÃO DE ARQUITETURA BIOCLIMÁTICA E OS CUSTOS EM CADA ESTÁGIO.

\begin{tabular}{|c|c|c|}
\hline $\begin{array}{l}\text { Estágio } \\
\text { do projeto }\end{array}$ & $\begin{array}{l}\text { Potencial de aplicação de } \\
\text { estratégias bioclimáticas } \\
\text { e eficiência energética }\end{array}$ & $\begin{array}{l}\text { Custo de aplicação } \\
\text { das estratégias }\end{array}$ \\
\hline $\begin{array}{l}\text { Programa (tipo de } \\
\text { edifício, localização, } \\
\text { entorno) }\end{array}$ & Muito alto & $\begin{array}{l}\text { Potencial de alternativas } \\
\text { a baixo custo }\end{array}$ \\
\hline $\begin{array}{l}\text { Estudo preliminar } \\
\text { (forma e tipologia) }\end{array}$ & Alto & $\begin{array}{l}\text { Baixo custo (decisões } \\
\text { de volume, orientação } \\
\text { e forma) }\end{array}$ \\
\hline Pré-executivo & $\begin{array}{l}\text { Limitado ao ajuste } \\
\text { dascaracterísticas } \\
\text { bioclimáticas }\end{array}$ & Alto \\
\hline $\begin{array}{l}\text { Detalhes e } \\
\text { especificação }\end{array}$ & Muito limitado & $\begin{array}{l}\text { Alto-importante } \\
\text { devdo às modificações }\end{array}$ \\
\hline Construção & Muito limitado & $\begin{array}{l}\text { Elevado custo das } \\
\text { modificações }\end{array}$ \\
\hline Uso & Extremamente limitado & $\begin{array}{l}\text { Elevado custo das } \\
\text { modificações }\end{array}$ \\
\hline
\end{tabular}

Fonte: EVANS, 2007.

uma rede internacional de Hotéis em São Paulo. Este levantamento, realizado em duas etapas, descritas a seguir, consta integralmente no Apêndice A.

A primeira etapa consistiu em um levantamento das características da arquitetura - dimensionamento dos apartamentos, características do sistema construtivo, composição dos materiais internos e externos, fontes internas geradoras de calor nos apartamentos, lâmpadas e equipamentos.

Na segunda etapa foram levantados, num ciclo de medições em duas unidades habitacionais (UH), as seguintes variáveis: temperatura do ar, temperatura de globo, umidade relativa e velocidade do ar (externa). Essas medições foram feitas em dois apartamentos em fachadas opostas, portanto com orientações diferentes (SO e NE), situados no sétimo (penúltimo) andar tipo do Hotel. Ambas as unidades habitacionais (UH) permaneceram com as janelas fechadas e com o sistema de ar condicionado (SAC) desligado durante esse período. 


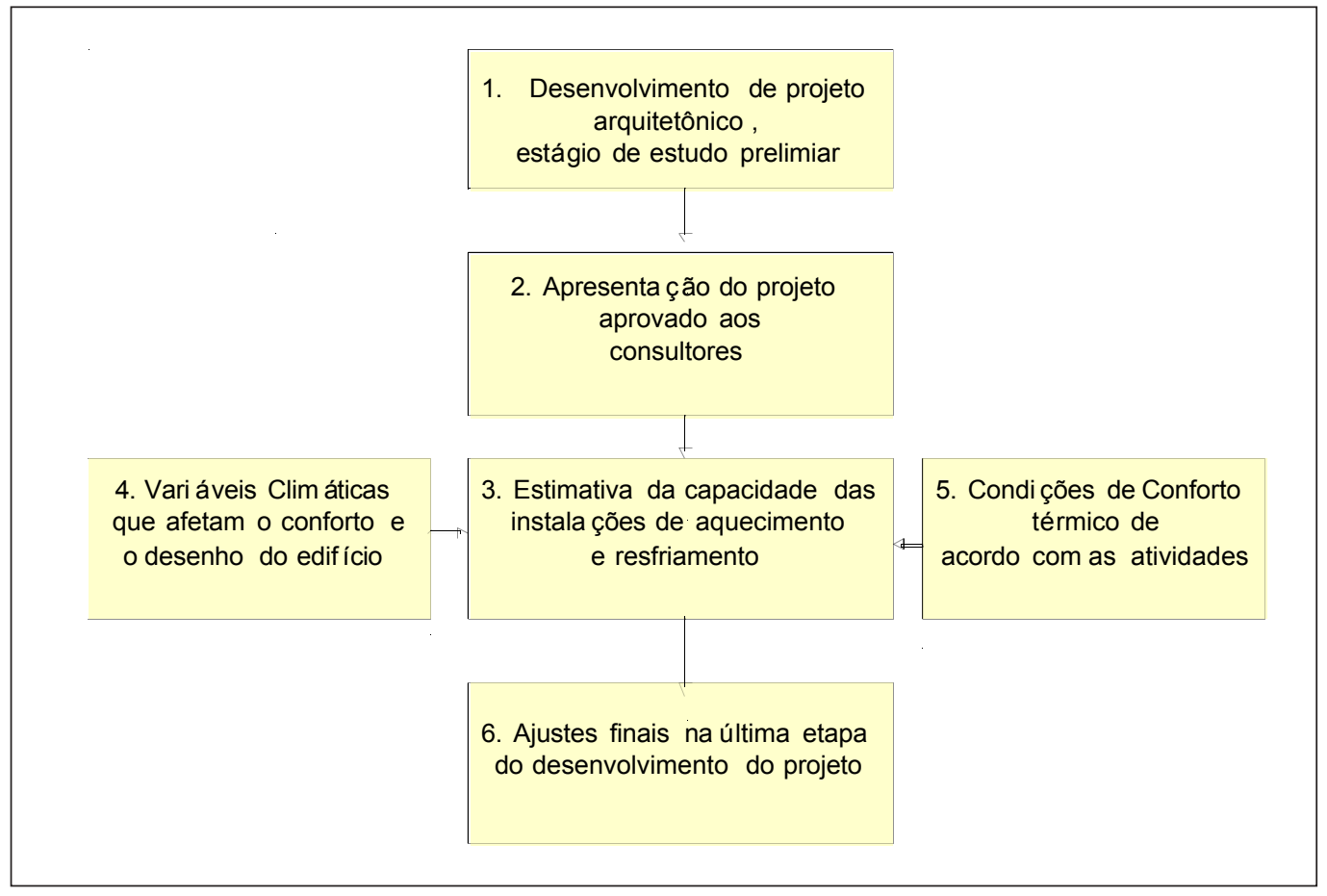

Ilustração 36: Diagrama dos estágios de Projeto.

Fonte: EVANS, 2007.

Durante o período de medições, a ocupação noturna dos apartamentos foi controlada com os denominados "hóspedes de controle" (Apêndice C), responsáveis pelo preenchimento dos questionários desenvolvidos pela aluna (Apêndice B) para verificar seu período de banho, sua utilização do quarto e sua percepção quanto às condições de conforto.

O resultado destas medições foi o entendimento de como o modelo de arquitetura do hotel responde às variáveis externas e internas, indicando as maiores fontes de calor e as diferenças de temperaturas do ambiente interno com relação ao externo, para fundamentar a proposta de um novo projeto de Hotel Econômico.

O processo de projeto de arquitetura segue uma seqüência de estágios, como pode-se verificar na TAB. 7. Quanto mais cedo neste processo forem definidas as estratégias bioclimáticas e de eficiência energética maiores as chances de se obter melhor desempenho do edifício. Os estágios de projeto devem ser criteriosamente definidos, para evitar que continuem perpetuando-se os estágios convencionais de projeto, descrito por de Evans (2007), na IL.36.

Por isto merece destaque fazer uma análise da metodologia de projeto para que a seqüência de projeto possa auxiliar da melhor forma a tarefa do arquiteto de atender tanto as necessidades de conforto dos usuários quanto à eficiência energética. 


\subsection{Metodologia de projeto}

Segundo Corbella e Yannas (2003), a arquitetura com qualidade ambiental tem como objetivo prover um ambiente construído com conforto físico,s adio e agradável, adaptado ao clima local, e que minimize o consumo de energia elétrica, assim como a potência instalada de equipamentos, e que reduza também a produção de poluição.

Mueller (2006) apresentou o que seria o processo metodológico para a elaboração de projetos com qualidade ambiental.

Para que um projeto arquitetônico tenha qualidade ambiental e atenda aos requisitos mencionados acima, Mueller (2006) propõe que a seqüência no processo de projeto do arquiteto seja a seguinte:

1. Análise do Programa Arquitetônico (programa de necessidades e prédimensionamento das áreas)

2. Análise do terreno e entorno (insolação, ventilação, níveis de ruído externo, ocupação do solo)

3. Aplicação da bioclimatologia ${ }^{12}$ à arquitetura (diagnóstico climático, componentes construtivos, forma ótima do edifício)

4. Avaliação do desempenho do edifício (critérios para avaliação- parâmetros de conforto)

5. Reavaliação do projeto e detalhamento

Verifica-se assim que existe uma relação fundamental entre o programa arquitetônico e o que a autora denomina a aplicação da bioclimatologia à arquitetura- que seria a interação das condições climáticas para estabelecer estratégias de intervenção no projeto arquitetônico.

Dessa forma, propõe-se uma metodologia de projeto, cuja seqüência esta apresentada na IL. 37 que auxilie os arquitetos no sentido de obter o melhor desempenho de suas funções, criando espaços com qualidade ambiental sem desperdício dos recursos naturais disponíveis no local em que se encontra um dado projeto. A seqüência proposta seria:

\footnotetext{
12. Entende-se como bioclimatologia a ciência que aplica os estudos do clima, a climatologia, às relações com os seres vivos. Com o conhecimento dos conceitos básicos de clima e conforto, percebe-se a importância da bioclimatologia aplicada à arquitetura, já que é possivel tirar proveito ou evitar as condições climáticas, de forma a propiciar, para os usuários de edifícios, um ambiente interno confortável (BOGO et. al, 1994).
} 


\begin{tabular}{|c|c|}
\hline Seqüẽncia de Atividades & Descriçāo de Procedimento \\
\hline $\begin{array}{l}\text { 1. Análise do Programa } \\
\text { Arquitetönico }\end{array}$ & Programa de necessidades, áreas e fluxograma \\
\hline $\begin{array}{l}\text { 2. Análise da Condiẹảo de } \\
\text { exposiçāo }\end{array}$ & $\begin{array}{l}\text { Aproveitamento das condiçōes do entorno: } \\
\text { Insolaçāo, ventilaçāo, ruido e taxa de ocupaçāo }\end{array}$ \\
\hline 3. Diagnóstico climático & $\begin{array}{l}\text { Definiçāo das estratėgias de projeto: Passivas ou } \\
\text { Ativas }\end{array}$ \\
\hline 4. Indices de conforto & Definiçāo dos critèrios a serem utilizados \\
\hline $\begin{array}{l}\text { 5. Seleçāo dos recursos de } \\
\text { projeto bioclimático }\end{array}$ & $\begin{array}{l}\text { Interaçāo do programa com padrāo de uso e } \\
\text { diagnóstico climático }\end{array}$ \\
\hline 6. Opçăo de condicionamento & Escolha entre o natural, artificial ou misto \\
\hline $\begin{array}{l}\text { 7. Avaliaçāo dos resultados para } \\
\text { as condiçōes naturais }\end{array}$ & $\begin{array}{l}\text { Assegurar o bom aproveitamento das condiçōes } \\
\text { naturais }\end{array}$ \\
\hline $\begin{array}{l}\text { 8. Avaliar a porcentagem de } \\
\text { pessoas satisfeitas }\end{array}$ & $\begin{array}{l}\text { Verificar o quanto os usuảrios estāo em conforto } \\
\text { segundo critèrios estabelecidos }\end{array}$ \\
\hline $\begin{array}{l}\text { 9. Estimativa da capacidade do } \\
\text { sistema de Ar condicionado }\end{array}$ & $\begin{array}{l}\text { Avaliar o projeto, suas necessidades, e interface com } \\
\text { o SAC }\end{array}$ \\
\hline $\begin{array}{l}\text { 10. Avaliar o consumo de } \\
\text { energia e características } \\
\text { arquitetónicas }\end{array}$ & $\begin{array}{l}\text { Considerar a opçào de condicionamento e os } \\
\text { critérios utilizados para avaliá-los }\end{array}$ \\
\hline \multicolumn{2}{|c|}{$\begin{array}{l}\text { RESULTADO: Sugestäo de projeto considerando o melhor desempenho da arquitetura } \\
\text { com eficiència energètica }\end{array}$} \\
\hline
\end{tabular}

Ilustração 37: Seqüência metodológica de projeto - proposta

1. Análise do programa arquitetônico;

2. Análise da condição de exposição;

3. Estudo das condições climáticas- definição das estratégias de projeto passivas/ ativas;

4. Determinação das condições de conforto térmico;

5. Seleção de recursos de projeto bioclimático;

6. Opção pelo condicionamento natural, artificial ou modo misto;

7. Avaliação dos resultados das condições naturais;

8. Avaliação do conforto dos usuários e das características arquitetônicas;

9. Estimativa da capacidade do sistema de ar condicionado;

10. Avaliação do consumo de energia de das características arquitetônicas. 


\subsection{O programa Arquitetônico de Hotéis Econômicos}

Com base nas características do edifício a ser projetado, no caso específico desta pesquisa sobre Hotéis Econômicos, deve-se verificar as funções exercidas no espaço interno, as áreas necessárias para cada uma delas, suas relações e a seqüência operacional entre as atividades ali exercidas.

$\mathrm{Na}$ etapa inicial do processo de projeto, recomenda-se que sejam pesquisados também edifícios da mesma tipologia e, preferencialmente, com o mesmo programa de necessidades, para que possam ser verificadas as soluções propostas e sua adequação com o objetivo de aprimorar o programa arquitetônico.

\subsubsection{Análise do programa de necessidades, áreas e fluxograma}

A localização das funções exercidas no interior do hotel pode ser definida, nesta fase, de acordo com as prioridades quanto ao conforto ambiental, à orientação e à acessibilidade. Para os espaços externos, nesta etapa já são definidas quais áreas e quais tratamentos devem ser dados para a criação de micro climas específicos e suas relações com os ambientes internos.

Conforme foi apresentado anteriormente na inter-relação básica dos ambientes em um hotel (seção 3.2.1, IL. 29), essas relações devem ser devidamente analisadas, para que o resultado final tenha o menor número de atividades e usos em conflito de localização que possam prejudicar o bom funcionamento do Hotel.

É importante salientar que, devido às dimensões reduzidas ao mínimo para o máximo de eficiência do hotel em todos os sentidos (financeira, operacional) esta análise de programa e a possibilidade de integração de uma área de serviço com outra, como no caso de algumas recepções integradas ao balcão do bar de entrada, muitas vezes resultam em soluções inusitadas e funcionais.

A restrição de funcionários e a limitação dos espaços acabam exigindo dos arquitetos algo mais do que uma simples análise do programa de necessidades: uma análise da operacionalidade do hotel.

\subsubsection{Padrões de operação: uso e ocupação}

Evans (2005) definie duas categorias de edifícios: os simples (com poucos ganhos de calor internos, ventilação e iluminação natural, e sistemas simples de 
aquecimento em regiões mais frias) e os mais complexos (com várias fontes de ganhos de calor internos devido aos ocupantes e equipamentos), com plantas profundas, onde a iluminação e ventilação são feitas fundamentalmente por meio artificial.

Neste segundo caso, trata-se dos edifícios onde dificilmente é possível evitar o uso de SAC, mas nos quais ainda é possível e necessário reduzir a demanda energética.

O uso e a ocupação desses hotéis podem ser subdivididos em quatro partes principais:

1. As áreas das Unidades Habitacionais (UH);

2. Área de uso comum (recepção, bar, lobby);

3. Áreas de serviço (cozinha, salas administrativas etc..);

4. Setor de eventos (quando houver).

Com relação às UH, a determinação do período de ocupação e da utilização dos equipamentos de televisão e luz geral do ambiente foram pré-definidas pela autora e se basearam em pesquisas de BUORO, et. al (2004) e MESOUITA, (2006). Nesses dois trabalhos, foram realizadas Avaliações Pós-Ocupação (APO) com usuários de alguns Hotéis Econômicos em São Paulo, capital e interior. Entre as conclusões desses trabalhos, está o fato da ocupação das UH ocorrer apenas no período da noite em mais de $80 \%$ dos hóspedes, sendo os apartamentos utilizados para descanso (dormir), relaxamento (assistir televisão ou ler um livro) e higiene pessoal.

Os ganhos de calor ocorridos nessas áreas estão listados no Apêndice A, porém trata-se de um dado que, no caso dos hotéis, se refere à ambientes privativos, não controlados diretamente pelo gerente, ou seja, em que um hóspede pode manter todas as luzes acesas e a TV ligada durante todo o período de estada no Hotel, mesmo que, em grande parte do tempo, esteja dormindo. Dessa forma, recomenda-se que os equipamentos sejam os mais eficientes do mercado e que exista alguma alternativa, principalmente quanto à iluminação artificial (caso um hóspede tenha o hábito de dormir com alguma luz acesa) de um ponto de luz que sirva a essa finalidade tanto quanto seja energeticamente eficiente. Neste caso, já se encontram no mercado diversas luminárias que usam os LEDs ${ }^{13}$. Com o barateamento do preço, seu alto rendimento e sua grande durabilidade, os LEDs tornam-se ótimos substitutos para as lâmpadas comuns (WIKIPEDIA, 2007).

13. O LED é conhecido como um tipo de lâmpada mais eficiente do que as incandescentes e fluorescentes. Trata-se de um dispositivo eletrônico composto de cristal de silício ou germânio que, quando energizado, emite luz visivel. 
No levantamento de dados empíricos em estudo de caso, considerando que o objeto de estudo é a UH, e que a ocupação foi controlada, ficou estabelecido tanto o período de funcionamento da televisão quanto o do acionamento das lâmpadas na UH, conforme apresentado no Apêndice C.

\subsection{Diagnóstico Climático}

O clima de São Paulo, a partir de uma arquitetura compatível com o clima, propicia a obtenção de conforto sem fazer uso de alternativas ativas na maior parte do ano. A análise climática com este método aponta para a necessidade de soluções arquitetônicas que respondam ao rigor do clima, e que são considerados os valores de temperatura e umidade do ar, exceto os valores de radiação solar, que são se apresentam como resultado das altas temperaturas.

Trata-se de uma avaliação preliminar do clima externo, sem considerar os efeitos das condições internas tais como: o amortecimento dos componentes da fachada e coberturas aos ganhos de calor externos, ou os ganhos e perdas de calor proveniente das pessoas, equipamentos e iluminação. Estes ganhos, dependendo das condições climáticas externas, podem ser favoráveis ou desfavoráveis ao conforto térmico.

De acordo com o Balanço Térmico de São Paulo (ALUCCI, 2005) apenas 3,1\% do ano realmente necessita de condicionamento artificial, conforme indicado na IL.38. Para o restante do ano, $63,5 \%$, pode-se obter conforto por meio de ventilação que, somado à porcentagem de $17 \%$ de zona de conforto, resulta num total de 80,5\% de período confortável. Desse modo, um projeto que considere as possibilidades passivas de conforto térmico pode, na maior parte do ano, não utilizar o ar condicionado.

Sabe-se que um projeto que possibilite uma ventilação adequada, aliada à orientação das janelas e aos materiais que compõem os elementos da fachada, reduziria de forma significativa o consumo de energia com ar condicionado.

Apesar dos empreendimentos de categoria econômica não serem obrigados a ter esses sistemas, de acordo com os critérios de classificação da EMBRATUR (EMBRATUR, 2002), as redes hoteleiras os adotaram e os hóspedes passaram a exigir tais equipamentos quando hospedados nestes hotéis.

Considerando o período de ocupação dos Hotéis Econômicos, que ocorre predominantemente das 20 às 8 horas, o Balanço Térmico deste período, apresentado na IL. 39, tem outro resultado: 70\% com uso da ventilação natural, e os 30\% restantes, nos meses mais frios do ano, massa térmica de aquecimento. 


\section{BALANÇO TÉRMICO ANUAL (24 horas diárias)}

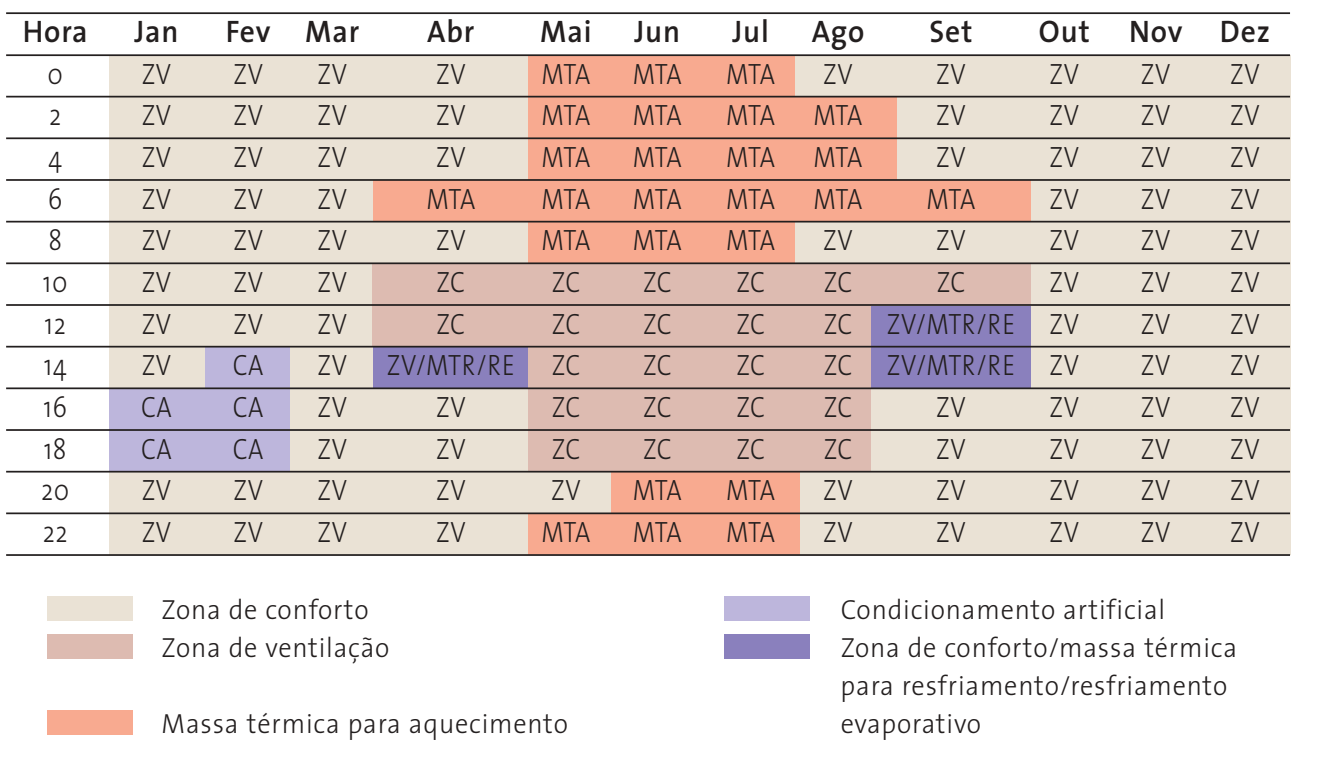

Ilustração 38: Diagnóstico climático de São Paulo - método GIVONI Fonte: ALUCCI, 2005.

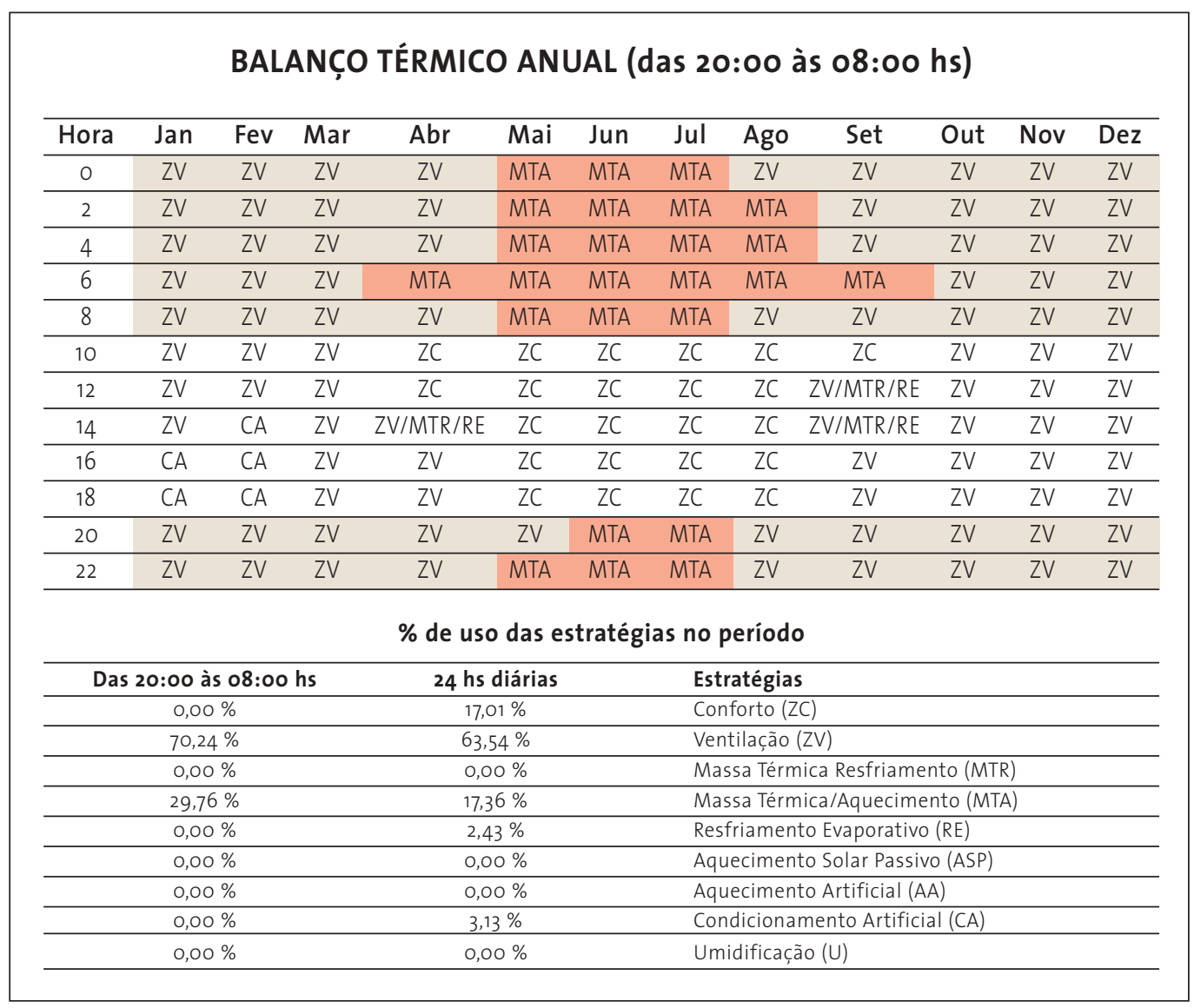

Ilustração 39: Diagnóstico climático de São Paulo, com separação do período de ocupação (cor). Fonte: ALUCCI, 2005. 
Esta diferença ocorreu porque nos dados climáticos, considerando o período de ocupação, as temperaturas são mais baixas tanto no verão quanto no inverno, e foram excluídos os períodos do ano em que se estariam em conforto (que era dos meses de abril a agosto, das 10 ás 18 horas).

Os edifícios projetados que desconsideram as recomendações do diagnóstico climático podem estar fadados a fazer uso do SAC, por exemplo, mesm quando as condições climáticas indicam para o aproveitamento da VN como a estratégia para se obter conforto, podendo assim resultar em edifícios energeticamente ineficiente.

\subsection{Condições de exposição: o entorno}

Nessa fase, deve-se avaliar o terreno no qual é prevista a implantação de um dado hotel. Conforme foi descrito anteriormente, na seção 3.1.1, a localização é uma das estratégias das operadoras mais importantes para o sucesso do empreendimento hoteleiro.

Esta etapa do processo de projeto deve ser vista de forma a complementar a etapa anterior (diagnóstico climático). As características do entorno interferem nas condições naturais, na ventilação natural, na insolação e nas condições acústicas externas. Podem ocorrer situações do entorno que as são melhoradas as condições de ventilação externas ao mesmo tempo em que piorar as de insolação e acústica externa, por exemplo.

O posicionamento de um edifício em terreno situado junto a vias de circulação rápida tende a determinar níveis de ruído externo elevados, já que estas são os principais acessos da cidade e, portanto, ocupam uma localização privilegiada e adequada para um edifício da tipologia hoteleira.

As condições dos edifícios de Hotéis Econômicos, com ocupação predominante no período noturno, para dormir, necessitam de uma avaliação específica da condição de exposição do entorno.

É muito difícil apurar[...] em que medida o ruído urbano de trânsito num local da cidade afeta o repouso noturno das pessoas. A consciência do problema, a sensibilidade, o fato de se estar habitualmente muito ou pouco cansado ao se recolher para dormir, o fato de se estar mais ou menos acostumado ao ruído e diversos outros fatores permanentes, podem compor-se de inúmeras maneiras, levando a opiniões mais díspares das pessoas sujeitas a uma mesma condição de exposição (BARING, 1981, p. 49). 
Diversas pesquisas foram feitas com o objetivo de auxiliar o arquiteto nas várias etapas de projeto, entre elas, a de Brandão (2004), que desenvolveu um software para avaliar as condições de exposição ao Sol, em que são considerados como dados de entrada as características do entorno.

\section{5 Îndices de conforto térmico}

Para determinar a probabilidade de acionamento do ar condicionado pelo hóspede (quando as temperaturas internas ficam acima dos limites aceitáveis por eles), é de fundamental importância conhecer as normas nacionais e internacionais, bem como avaliar qual índice de conforto mais adequado a ser considerado.

As condições de conforto são regulamentadas por normas técnicas nacionais e internacionais e dividem os ambientes em condicionados artificialmente ou naturalmente. Essas normas indicam os parâmetros dos valores-limite dos seguintes itens, para que os seus ocupantes estejam em conforto:

- Temperatura do ar

- Umidade do ar

- Velocidade do ar

Os parâmetros de conforto também estão relacionados ao tipo de atividade exercida no ambiente e à vestimenta utilizada. FANGER (1972) estabelece três condições para a situação de conforto térmico:

1. A existência de equilíbrio térmico por meio da troca de calor ;

2. A temperatura média da pele;

3. O calor eliminado por evaporação do suor na zona de regulação contra o calor.

O índice de atividade térmica (IAT) foi definido por FANGER (1972) como a diferença entre a energia gerada no corpo para uma dada atividade e o calor trocado pela pele, sob condições de neutralidade térmica, para uma mesma atividade e um mesmo ambiente térmico, sendo essa, portanto, a medida da atuação do sistema termo-regulador.

Através de uma extensa pesquisa, com aproximadamente 1.300 indivíduos, Fanger determinou o voto médio (VME - Voto Médio Estimado, do inglês PMV Predicted Mean Vote) e chegou ao percentual de pessoas insatisfeitas (PPI Porcentagem de Pessoas Insatisfeitas, do inglês PPD - Predicted Percentual Disfadisfaction). 
A norma ISO 7730 adequou a pesquisa de Fanger (1972) a uma rotina de utilização para diferentes atividades, tipos de vestimenta e condições ambientais. Os limites da zona de conforto térmico estão indicados na TAB.8. Essa norma recomenda que se adotem os seguintes limites de $\mathrm{VME}:-0,5<\mathrm{VME}<0,5$, que corresponde a um PPI de $10 \%$, ou seja, $10 \%$ de pessoas insatisfeitas no ambiente.

Nessa mesma norma, diversas tabelas indicam os valores a serem considerados nos cálculos de VME e PPI, assim como gráficos que relacionam a temperatura operativa (ou VME=0), como função da atividade e vestimenta.

A norma brasileira da ABNT-NBR 6401 apresenta faixas de temperatura e umidade relativas, considerando diferentes ambientes (escritórios, hospitais, etc.).

A norma ASHRAE 55/1992 refere apenas à ambientes condicionados artificialmente. No entanto, a norma ASHRAE 55/2004, recentemente revisada, incorporou pesquisas relevantes, tais como a de De Dear, Brager e Cooper (1997), que incluíram o método de cálculo do VME e PPI e o conceito do modelo adaptativo. Ela se baseia nas mesmas condições determinadas pela norma ISO 7726 e ISO 7730, porém considera que a zona de conforto baseia-se num percentual de desconforto máximo de $20 \%$ (ou seja -0,82<VME<0,82). Acrescenta ainda a importância do comportamento de adequação fisiológica e a expectativa térmica (De DEAR, BRAGER e COOPER, 1997, p. 117).

O modelo adaptativo baseou-se numa extensa pesquisa experimental realizada por De DEAR, BRAGER e COOPER (1997), no período entre 1995 e 1997, em 160 edifícios situados em diversas regiões do mundo (excluindo Brasil). Nesta pesquisa, a característica mais importante era se o edifício possuia sistema de ar condicionado central ou se era naturalmente ventilado. Foram coletados quase 21 mil dados, com informações sobre os edifícios, condições climáticas e os usuários. Dos usuários, foram determinadas as vestimentas e atividades, aplicados questionários para avaliações subjetivas, destacando-se a satisfação de se poder controlar a abertura de janelas, no caso dos edifícios naturalmente ventilados.

Esta pesquisa reforça que a capacidade de adaptação do ser humano e baseia-se na relação entre três pontos principais, a saber:

1. No comportamento do ser humano a mudanças - ajuste de roupa, atividade, postura ou posicionamento no edifício.

2. Nas características fisiológicas de termo-regulação - que dependem da aclimatação (adaptação de um indivíduo a uma dada condição ambiental ), ou das características de um mesmo grupo de pessoas.

3. Características psicológicas - na mudança de expectativa, alteração de reação e sentidos. 


\begin{tabular}{|lll|}
\hline \multicolumn{2}{|c|}{ TABELA 8: LIMITES DAS ZONAS DE CONFORTO TÉRMICO DA ISO 7730} \\
\hline Parâmetro & Verão & Inverno \\
\hline Temperatura Operativa To $\left({ }^{\circ} \mathrm{C}\right)$ & 23 a 26 & 20 a 24 \\
\hline Umidade Relativa UR $(\%)$ & 30 a 70 & 30 a 70 \\
\hline Velocidade do $\operatorname{Ar}(\mathrm{m} / \mathrm{s})$ & até 1 & até 1 \\
\hline
\end{tabular}

Fonte: $1507730,1994$.

A capacidade humana de se adaptar ao ambiente ocorre através do balanço térmico do ser humano, que interage com o ambiente através de três variáveis:

- adequação da vestimenta;

- índice de metabolismo;

- velocidade do ar.

Segundo De Dear, Brager e Cooper (1997), é razoável criar uma expectativa de que a escolha por uma vestimenta e um determinado comportamento também sofrerão influência do clima externo e das diferenças de aclimatação. No período do experimento os autores não chegaram a nenhuma conclusão sobre a relação do metabolismo de um indivíduo em ambiente interno com as temperaturas médias externas, tanto para edifícios com sistemas de ar condicionado (SAC) quanto para os naturalmente ventilados (NV). Já com relação à velocidade do ar, tanto no caso dos edifícios com SAC quanto para NV, segundo essa mesma pesquisa, concluíram que os usuários tendem a aumentar a velocidade do ar, na medida em que aumentam as temperaturas.

No caso dos edifícios com ventilação natural em climas úmidos isto é facilmente observado quando os usuários abrem as janelas e ligam os ventiladores (De DEAR, BRAGER e COPPER, 1997, p. 116).

Nos ambientes condicionados artificialmente, são utilizadas normas e regulamentações. No Brasil, elas são:

- ABNT - Instalações Centrais de Ar Condicionado para Conforto Parâmetros Básicos de Projeto (NBR 6401). Associação Brasileira de Normas Técnicas, Rio de Janeiro, 1980.

- ANVISA - Orientação técnica da Agência Nacional de Vigilância Sanitária em Ambientes climatizados artificialmente de uso público e coletivo (2003) - 
Orientação técnica sobre os padrões referenciais de qualidade do ar interior.

As normas internacionais mais utilizadas como referência nas pesquisas brasileiras são:

- ANSI/ ASHRAE - AMERICAN NATIONAL STANDARDS INSTITUTE \& AMERICAN SOCIETY OF HEATING, REFRIGERATING AND AIR-CONDITIONING ENGINEERS. Ventilation and Acceptable Indoor Air Quality in Low-Rise Residential. (ANSI/ ASHRAE 62.2-1989). USA, 1989.

- ASHRAE Standard. Thermal Environmental Conditions for Human Occupancy. (ANSI/ASHRAE Standard 55/2004). American Society of Heating, Refrigerating, and Air-Conditioning Engineers.

- ISO 7730 (1994) - Moderate Thermal Environments: Determination of the PMV and PPD Indices and Specification Of the Conditions for Thermal Comfort.

Na última revisão da norma ASHRAE Standard 55 (2004), foram incorporados os métodos de cálculo do VME e PPI e o conceito da adaptabilidade dos usuários no meio. A recomendação da norma é que o projetista/arquiteto defina com o proprietário quais critérios adotar para a escolha do nível de conforto aceitável. A definição desse critério influencia diretamente o sistema de ar condicionado, assim como o próprio projeto de arquitetura.

Segundo essa norma, os seis fatores principais para determinação das condições de conforto térmico são:

- Índice metabólico (met);

- Resistência térmica da roupa (clo);

- Temperatura do ar (TBS);

- Temperatura radiante média (TRM);

- Velocidade do ar (v);

- Umidade relativa do ar (UR).

Para a pesquisa em questão, dois elementos são fundamentais para a compreensão das variáveis no caso de hotéis. A primeira seria o metabolismo que, para o estudo foi, na maior parte do período, basal e igual a 0,7 (referente à pessoa dormindo). A segunda seria a variação da vestimenta cujo impacto definitivamente interfere na sensação de conforto, por estar relacionada a um ambiente privativo, no qual o usuário tem total liberdade de alterá-la, mesmo inconscientemente, quando estiver dormindo.

Sobre esses dois assuntos, a ASHRAE 55- 2004 resaltou: 
Para todas as atividades, exceto as atividades sedentárias, o índice metabólico para uma data atividade realizada tende a ter uma variação que depende do seu desempenho individual na realização desta atividade/ tarefa, e nas circunstâncias nas quais a tarefa está sendo desempenhada (ASHRAE 55, 2004, p. 16).

Com relação a resistência térmica da roupa (clo) acrescentou:

Quando uma pessoa está dormindo ou descansando reclinada a cama os lençóis e cobertores podem prover considerável controle térmico. Não é possível determinar a resistência térmica da maioria das situações de pessoas dormindo ou descansando a não ser que o indivíduo esteja imóvel. Os indivíduos podem ajustar as suas cobertas de acordo com a preferência individual. Estão disponíveis materiais adequados de cobertas para cama, porém as condições térmicas desejadas nestas situações variam consideravelmente de pessoa pra pessoa e não podem ser determinadas pelo método incluso nesta norma (ASHRAE 55, 2004, p. 17).

Nos últimos 10 anos, diversas pesquisas vêm sendo desenvolvidas sobre indices de conforto, tanto em ambientes naturalmente condicionados quanto nos de modo misto (com VN e SAC) que utilizam como critério o modelo adaptativo apresentado acima. Elas compararam a aplicação dos índices de conforto com o clima e outras variáveis, como a vestimenta e a atividade. Andreasi e Lamberts (2006), em experimento realizado na região Centro-Oeste brasileira, concluíram que, para ambientes com ar condicionado, tanto a metodologia de Humphreys e Nicol (2002) quanto a ISO 7730 (1994) são adequadas para avaliar as pessoas em atividades sedentárias (1,3 met $\left.^{14}\right)$. Esse resultado é decorrente da pequena variação em seu experimento. Destacaram também que, na metodologia de HUMPREYS e NICOL (2002), os valores foram ainda um pouco melhores do que os verificados na VST e no cálculo de VME, utilizando a ISO 7730 (1994).

No entanto, em ambientes naturalmente ventilados, os mesmos pesquisadores concluíram que a ISO 7730 não contribui para a avaliação do conforto térmico em clima quente e úmido, devido às características da região. Isso porque a norma ISO7730 determina como limite máximo $30{ }^{\circ} \mathrm{C}$, e os limites de temperatu-

14. Tanto o calor produzido como o dissipado dependem da atividade desenvolvida por um indivíduo. Em repouso absoluto - o chamado metabolismo basal-, o calor dissipado pelo corpo e cedido ao ambiente é de $75 \mathrm{~W}$. 


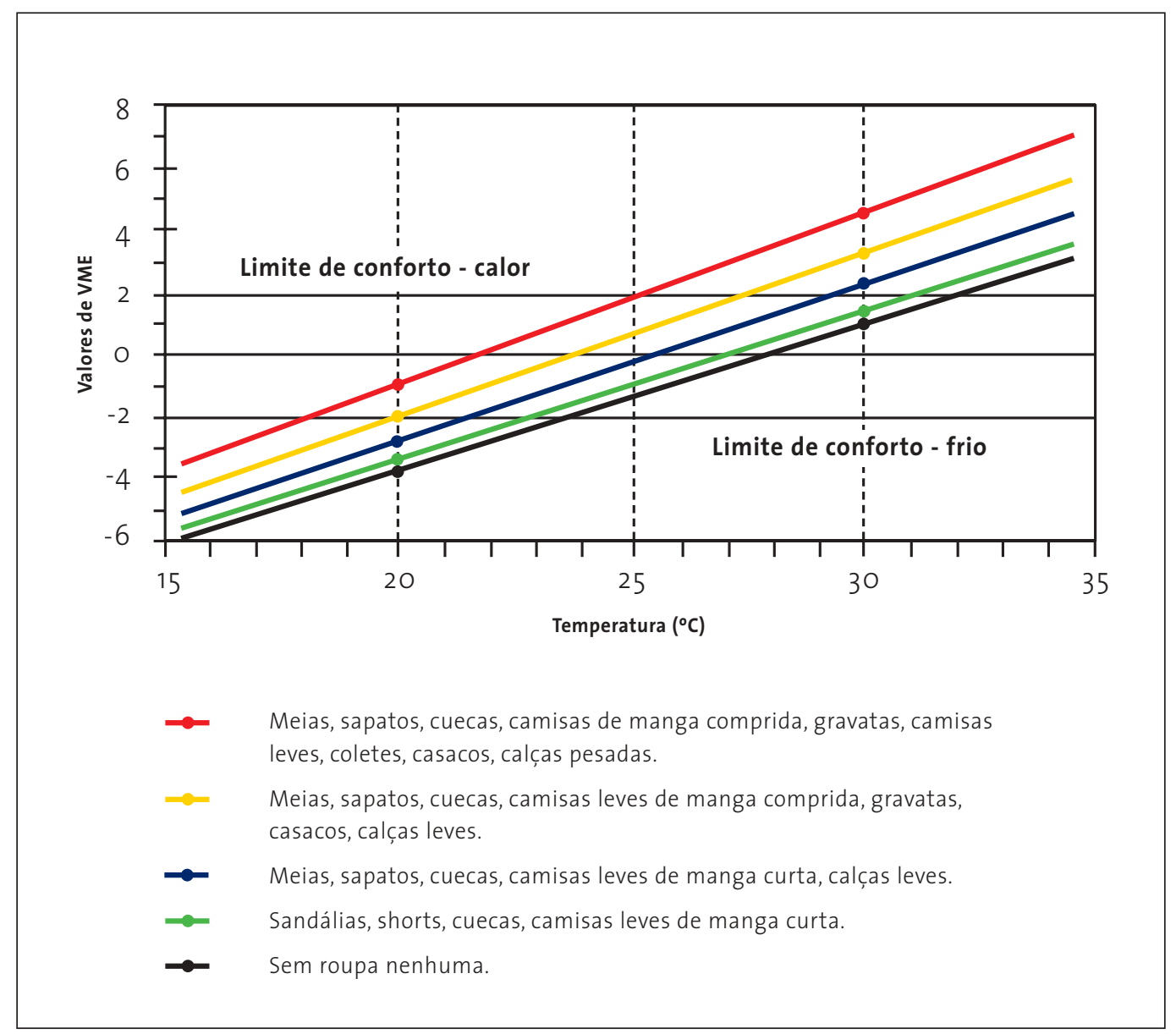

Ilustração 40: Gráfico de variáveis na escala de conforto modificado por Fanger Fonte: FORDHAM, 2006.

ra do local da pesquisa eram superiores a isso, além do valor do VME calculado, que também foi superior a +2,o na escala de Fanger (quente).

Fordham (2006), em gráfico adaptado de Fanger, na IL. 40, acrescentou que pequenas mudanças de vestimenta, ou seja, a resistência térmica da roupa (clo) produzem grandes variações de valores do VME, apesar de uma pequena mudança na sensação de conforto. Além disso, Fordham sugere que o limite de tolerância do VME, seja na escala de +/- 2, ou seja, mais restritivo do que os limites da ASHRAE, que são de +/- 3 .

Na pesquisa de Fanger foram assumidos os valores da temperatura superficial da pele, sem a interferência das adaptações culturais. Segundo Fordham, isto resulta em valores que deveriam ser bem diferentes em paises de clima subtropical, comparados com os de clima tropical úmido, por exemplo.

Na pesquisa de De BENEDETTO (2006), foi elaborado um arquivo climático para a cidade de São Paulo com os dados de temperatura dos últimos cinco anos. 


\begin{tabular}{|lll|}
\hline \multicolumn{3}{|c|}{$\begin{array}{l}\text { TABELA 9: TBS MÁXIMO E MÍNIMO NO DIA DE REFERÊNCIA } \\
\text { DE PROJETO DE VERÃO PARA SÃO PAULO }\end{array}$} \\
\hline & TBS SP $\left({ }^{\circ} \mathrm{C}\right)$ & UR SP(\%) \\
\hline Data & $11 / 02 / 2003$ & $11 / 02 / 2003$ \\
\hline Máxima & 35,0 & 86,20 \\
\hline Mínima & 23,0 & 73,9 \\
\hline
\end{tabular}

Fonte: De BENEDETTO, 2007 .

Os valores do TBS máximos e mínimos para o dia de referência de projeto (no verão) estão apresentados a seguir, na TAB.9.

O modelo de Humphreys (1978, apud Santamouris 1996) foi adotado por Alucci (2007), para determinar os níveis aceitáveis na faixa de temperatura de conforto para a avaliação do conforto térmico no programa computacional desenvolvido TAO. Dessa forma, a autora compara os limites para a temperatura de conforto definidos pela ASHRAE 55 (2004) e por Humphreys representados na IL. 41.

Comparando com o modelo adaptativo, até a temperatura média mensal de $27,6^{\circ} \mathrm{C}$, o modelo da ASHRAE 55 é mais abrangente, pois a faixa de temperatura dentro da zona de conforto considera uma temperatura mínima de $2{ }^{\circ} \mathrm{C}$ e máxima de $28,2{ }^{\circ} \mathrm{C}$. A curva indicada do modelo de Humphreys, em amarelo, quando a temperatura média mensal é superior a $27,6^{\circ} \mathrm{C}$, é mais tolerante a temperaturas mais altas, apresentando-se mais inclinada do que no primeiro modelo. Em contrapartida, abaixo da temperatura média mensal de $22{ }^{\circ} \mathrm{C}$, considerando o cruzamento dos limites inferiores dos dois modelos, Humphreys aceita valores mais baixos do que os determinados pela ASHRAE 55/2004.

Após a avaliação do diagnóstico climático e definidos os índices de conforto a serem considerados de acordo com o padrão de uso e ocupação do edifício, decide-se pelo condicionamento ambiental: natural, artificial ou misto (natural e artificial). Quaisquer que sejam as decisões, todas devem atender ao código de obras do município e ao plano diretor da cidade. 


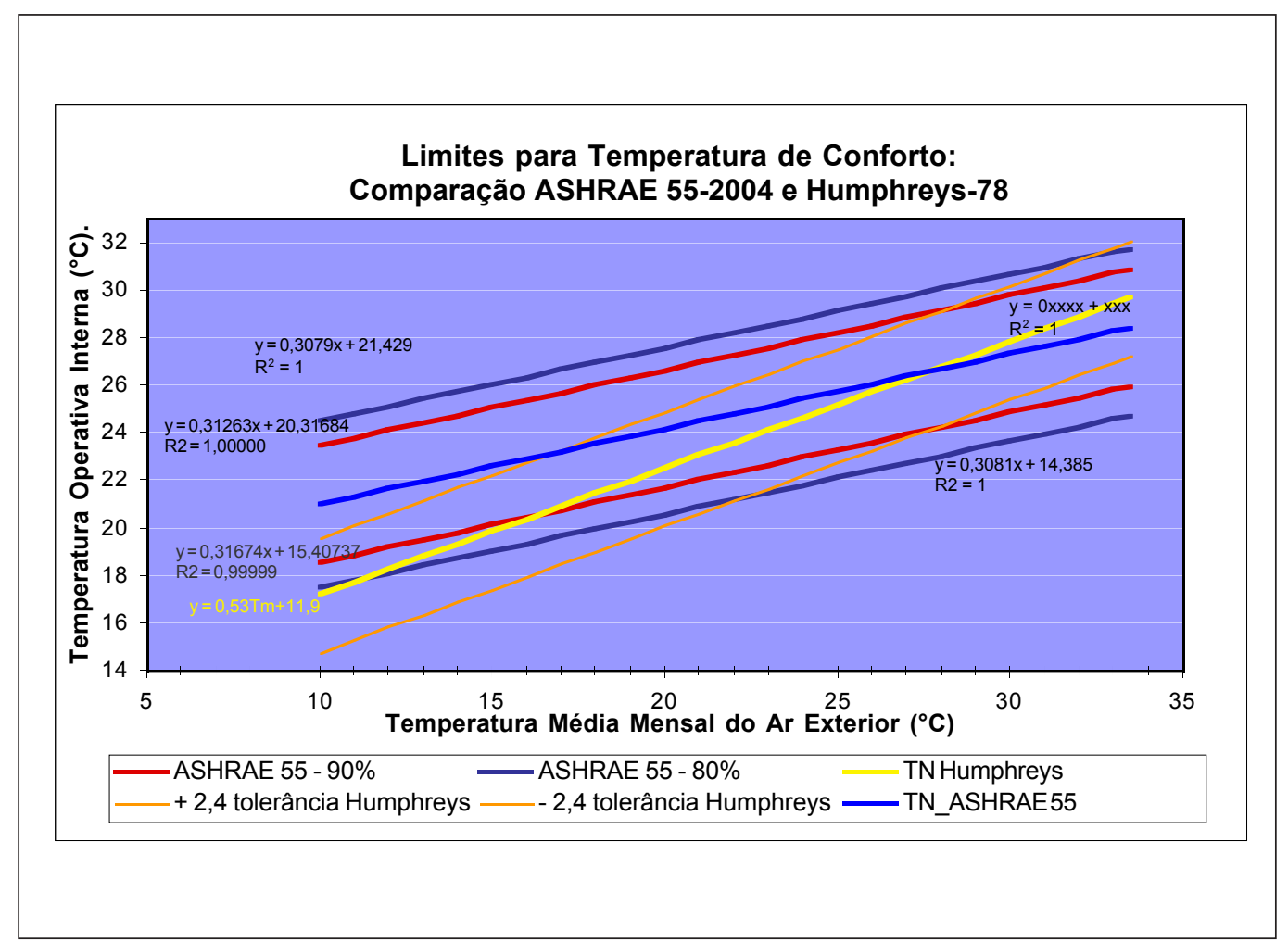

Ilustração 41: Comparação dos limites de temperatura de conforto pelo modelo da ASHRAE 55 (2004) com o modelo de Humphreys (1978) Fonte: Humphreys (1978, apud Santamouris 1996).

\subsection{Opção pelo condicionamento natural}

Quando as condições de conforto são atendidas por meio do condicionamento natural, algumas definições, ainda na fase de projeto, são determinantes para o melhor desempenho do edifício nessas condições.

\section{$1^{\circ}$. Adequar a implantação e forma do edifício ao programa:}

Num primeiro momento da fase de projeto, deve-se avaliar adequadamente a implantação e a forma do edifício no terreno em questão e ao programa.

\section{$2^{\circ}$. Redução dos ganhos de calor por meio das fontes internas e externas.}

Quando se considera desde a concepção inicial de um projeto, tendo sido já levadas a cabo as fases preparatórias de projeto (estudo do programa, diagnóstico climático, levantamento das estratégias de projeto), a redução dos ganhos de calor, comparada com um projeto convencional (EVANS, 2007), certamente já está sendo levada em conta.

No caso de edifícios existentes, uma avaliação de todas as fontes de ganhos de calor deve ser criteriosamente feita, para que sejam levantadas quais fontes de 
calor podem ser reduzidas. Fala-se aqui principalmente do sistema de iluminação artificial e dos equipamentos, visto que a cada dia têm surgido novos equipamentos com consumo de energia e geração de calor cada vez menores, já que os ganhos devido às pessoas não podem ser reduzidos.

Outro elemento bastante importante nesse aspecto são as características construtivas, principalmente os ganhos devido às superfícies transparentes. A orientação mais desfavorável, aliada ao uso de vidros sem sombreamento, pode ser uma das maiores fontes de ganhos de calor e, muitas vezes, a adoção de sombreamento pode reduzir consideravelmente estes ganhos. No entanto, a integração dessa estratégia deve sempre considerar uma possivel redução da luz natural no interior do ambiente e, portanto, o projeto deve ser considerado como um todo, bem como a utilização das estratégias para torná-lo mais eficiente.

O método desenvolvido por Alucci (2007), que resultou no programa computacional TAO, demonstrou ser uma ferramenta importante para auxiliar nestas fases de projeto. Os procedimentos seguidos pelo programa TAO estão enumerados abaixo:

- Identificar condições de exposição para a edificação considerando a fase de uso;

- Selecionar as características construtivas da envoltória: aberturas e vedos;

- Calcular o desempenho térmico, acústico, luminoso e energético da edificação em questão de acordo com critérios preestabelecidos e definidos pelas normas;

- Comparar os resultados para as várias orientações do edifício, considerando os requisitos de conforto do usuário (normas);

- Identificar à alternativa "ideal" para a implantação do edifício.

Com base nestes critérios é definida a geometria ótima do edifício para o máximo proveito das condições naturais e o menor impacto em relação aos pontos negativos do entorno (como excesso de ruído urbano, por exemplo).

\subsubsection{Ventilação natural}

A ventilação natural é de grande importância para a higiene e salubridade em geral bem como para o conforto dos usuários.

Avaliar os modelos de esquadrias e suas respectivas taxas de ventilação efetiva, e verificar se a ocupação no interior do edifício não cria nenhuma barreira para o vento são os princípios de um projeto adequado para o aproveitamento desta estratégia e, consequentemente melhorar o desempenho do edifício. 


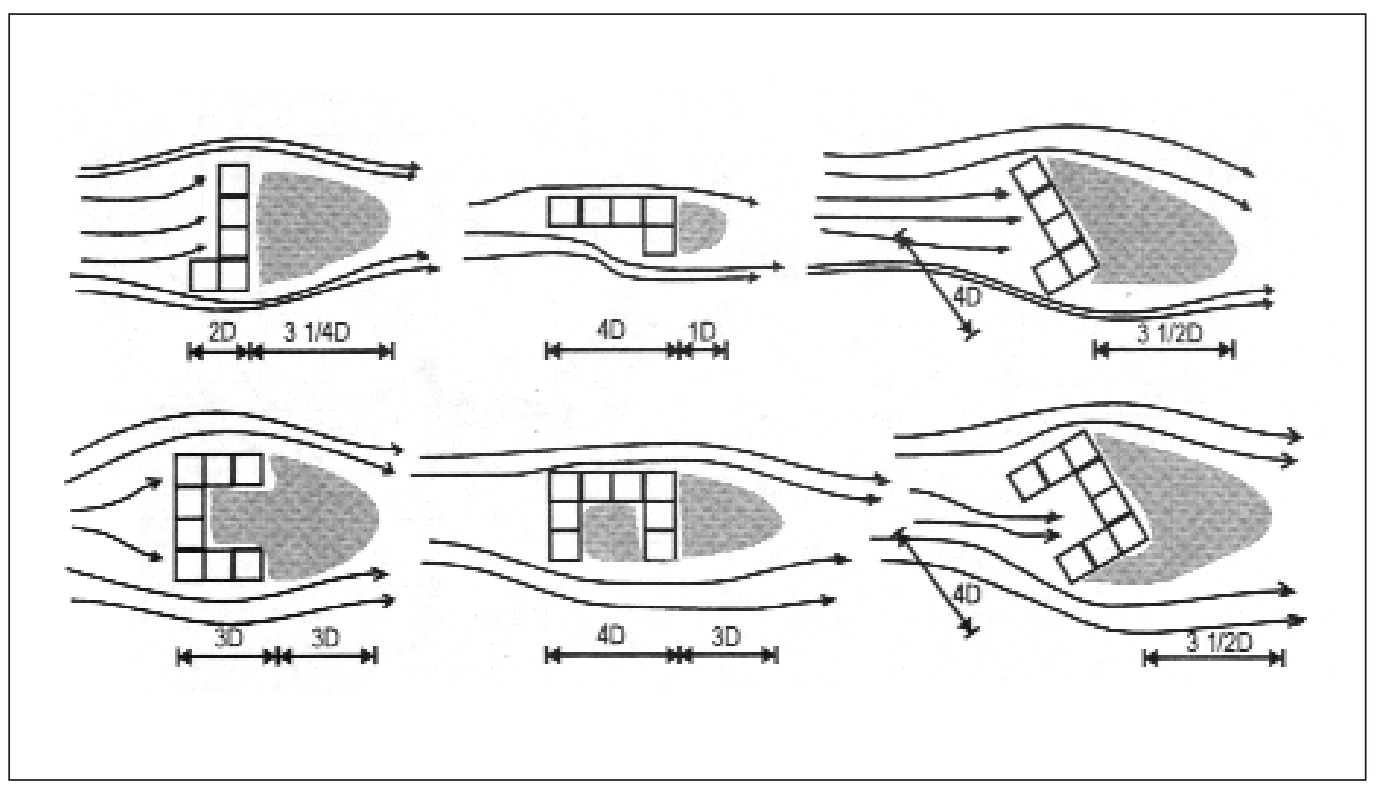

Ilustração 42: Comportamento do fluxo de ar em torno de edificações

Fonte: Adaptado de EVANS (1979) e BOULET (1987, apud Bittencourt e Cândido, 2005).

O fluxo do ar que entra em um edifício depende da diferença de pressão do ar entre os ambientes internos e externos, da resistência oferecida pelas aberturas ou obstruções internas e de uma série de implicações relativas à incidência do vento e à forma do edifício. Na IL. 42 pode-se verificar o fluxo de ar para diferentes formas de edifícios e a interferência que elas acarretam no entorno, a área em que não tem nenhum fluxo de vento, as chamdas "sombras de vento".

Existem alguns elementos na arquitetura do edifício, que maximizam a ventilação interna como o uso de estratégias que aproveitem da diferença de pressão e densidade do ar para movimentá-lo naturalmente para cima - o chamado efeito chaminé.

Ambientes com o pé direito alto ou de "chaminé solares" (sistema que aproveita da diferença de pressão associada ao geração de calor para direciobar o ar quente para cima) são conceitos que podem ser explorados nos projetos de arquitetura. Quando dimensionados corretamente, podem dispensar o uso do SAC nas condições climáticas com as de São Paulo.

A tipologia padrão do Hotel Econômico, de planta retangular e corredor central entre as UH, acaba prejudicando a exploração da ventilação cruzada. Apesar disto, pode-se encontrar muitas vezes, em especial nos Hotéis de categoria superiores como o Hotel Burj al Arab, em Dubai (ILs. 43 e 44), grandes vão centrais com andares escalonados que podem explorar tanto a ventilação cruzada, do exterior para o átrio, quanto o efeito chaminé, da saída da UH para o topo do átrio. 


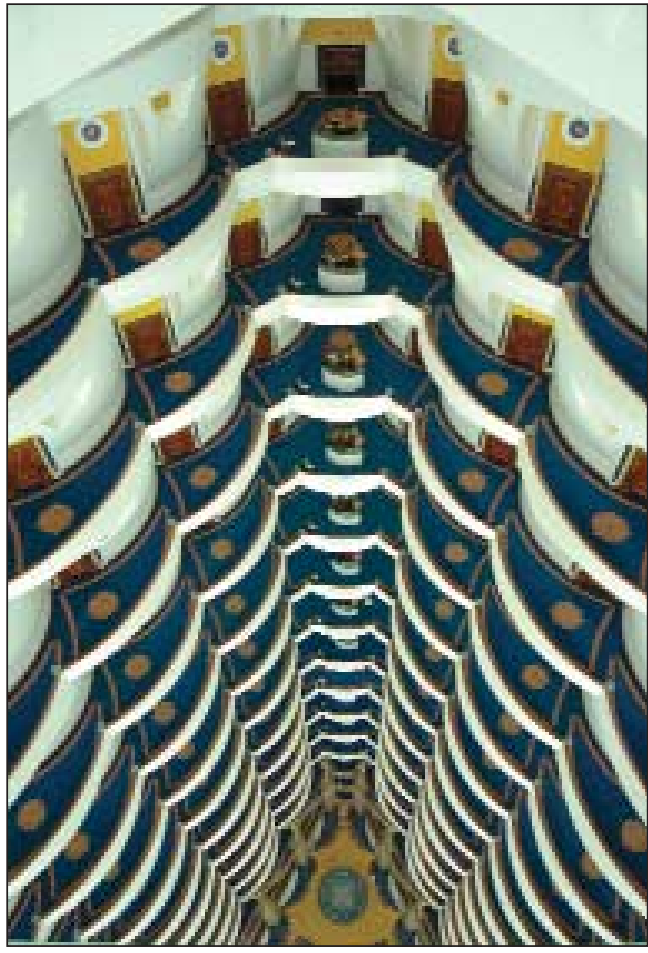

Ilustração 43: Átrio central do Hotel Burj al Arab em Dubai, vista aérea. Fonte: JUMEIRAH, 2007.

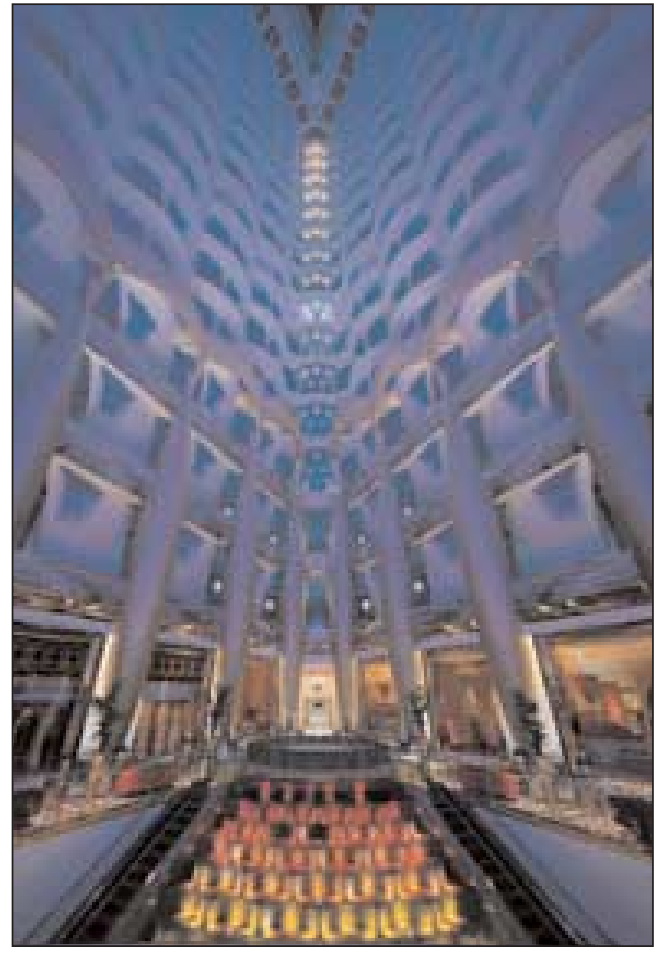

Ilustração 44: Átrio central do Hotel Burj al Arab em Dubai, vista do térreo.

Fonte: JUMEIRAH, 2007.

A ventilação natural pode ser explorada no projeto de arquitetura com ou sem o uso de sistemas mecânicos. Recomenda-se que eles sejam incorporados no projeto de arquitetura para atender as situações em que não há vento, e garantindo uma taxa de ventilação e renovação do ar adequada sem necessariamente depender do SAC.

No caso dos Hotéis econômicos próximos de grandes centros comerciais a ventilação natural pode estar associada a outros efeitos indesejáveis, tais como:

a. A poluição do ar

b. A poluição sonora

Existem projetos mantém o uso da ventilação natural sem acrescentar estes efeitos indesejáveis, como a proposta feita por Buoro, De Benedetto e Miura (2004), que, com a utilização de uma chicane ${ }^{15}$ absorve o ruído externo, ao mesmo tempo em que filtra as impurezas o ar provenientes da poluição da cidade, tornando-o de melhor qualidade do que o ar externo (IL. 45).

15. Chicane: Um seqüência de curvas em "S" que reduz a velocidade do ar e onde são posicionados absovervedores acústicos para evitar a transmição de ruído de um ambiente para outro. 


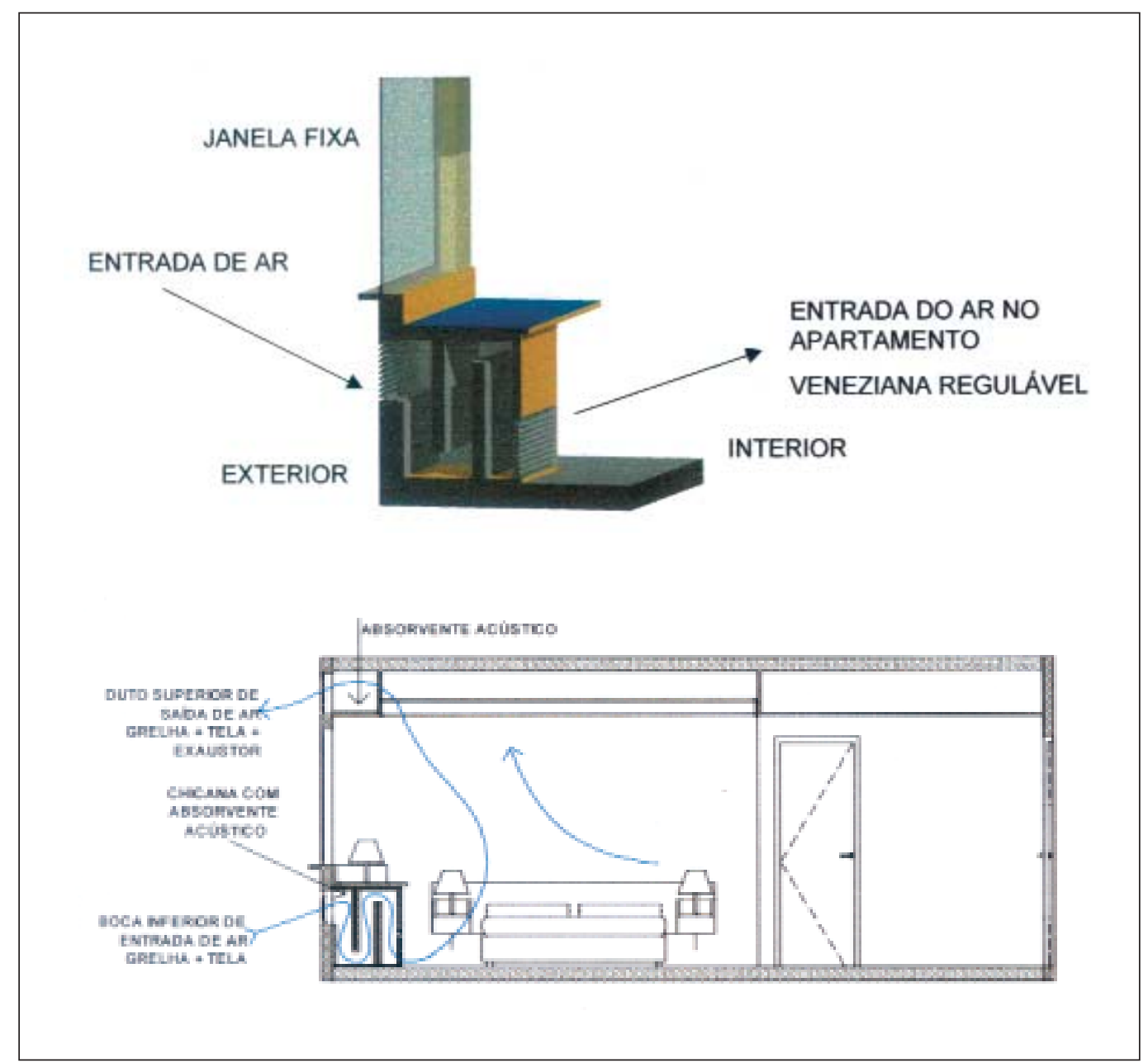

Ilustração 45: Recomendação de nova alternativa para a proveitamento da ventilação natural sem prejudicar o nível de ruído nem a qualidade do ar interna (cortes esquemáticos). Fonte: BUORO, De BENEDETTO e MIURA (2004).

\subsubsection{Dispositivos de proteção solar}

A necessidade de reduzir a incidência direta da radiação, controlar a disponibilidade de luz e, consequentemente, reduzir os ganhos solares através das aberturas, determinam o uso de dispositivos de proteção solar (brise-soleil).

Devido à característica termo-física dos vidros, a seqüência da radiação solar incidente sobre uma superfície translúcida, apresentada na IL.46 é a seguinte:
1. Fração do calor refletido e irradiado para exterior;
2. Fração absorvida pelo material (irradiado posteriormente para o exterior);
3. Fração absorvida pelo material (irradiado posteriormente para o o interior);
4. Fração do calor irradiado para o interior do ambiente;
5. Transmissão direta da radiação solar. 


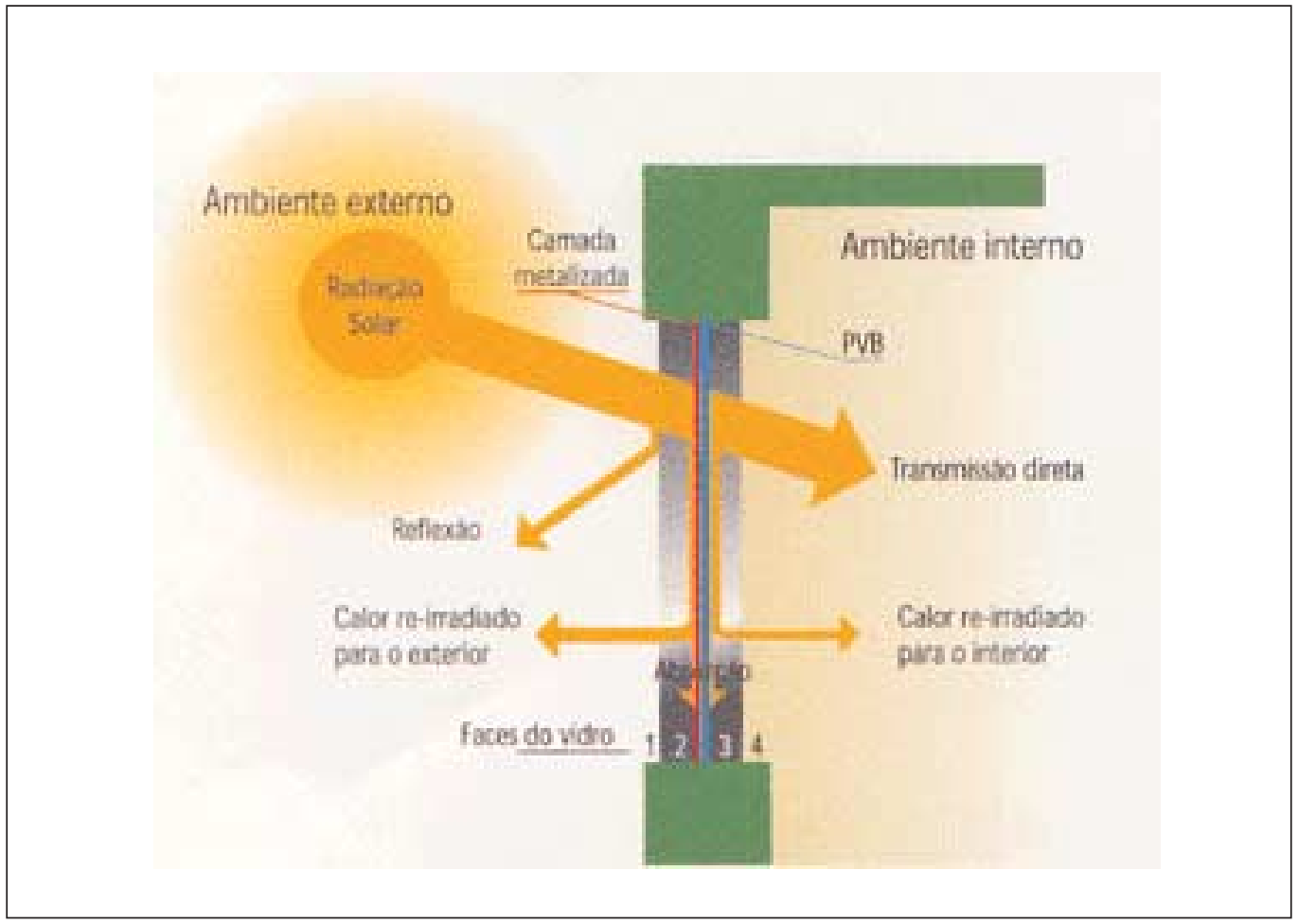

Ilustração 46: Variáveis na condutibilidade térmica dos elementos translúcidos Fonte: SAINT GOBAIN GLASS, 2007.

Outro fator importante que deve ser destacado aqui são as características dos vidros: cada fabricante, tipo de vidro (incolor, verde, reflexivo, entre outros), espessura, têm-se uma porcentagem de radiação solar visível (transmitida e refletida) e uma porcentagem da radiação solar total (transmitida direta, refletida externa, absorvida e o fator solar). Estas características interferem tanto do desempenho térmico, quanto no desempenho luminoso, e por isto devem ser avaliadas adequadamente em cada projeto.

O fator solar (Str) é a característica que determina qual é a fração do calor que é irradiado para o interior do ambiente. Quanto maior a parcela de radiação incidente no interior do ambiente, maior será o ganho de calor no interior do mesmo. Este ganho de calor, para o clima de São Paulo, não é recomendável nos meses mais quentes. No entanto, nos meses mais frios, de acordo com as características de ocupação do ambiente, podem auxiliar na melhoria das condições de conforto.

Por isto uma avaliação da carta solar de acordo com a orientação das aberturas em conjunto com as condições de ocupação ao longo do ano é determinante.

Segundo Gonçalves e Vianna (2001), o brise-soleil pode ser de três tipos:

- externos: fixos e reguláveis (manualmente ou com sistemas automatizados)

- internos: essencialmente reguláveis manualmente (cortinas e persianas) 
- incorporados dentro da própria envoltória da fachada: micro persianas fixas a reguláveis (manualmente e por sistemas automatizados) e películas internas ao vidro.

Qualquer um dos três tipos, dimensionados adequadamente podem auxiliar na redução da carga térmica tanto para ambientes condicionados natural quanto artificialmente, mas tendem a reduzir proporcionalmente a quantidade de luz natural disponível no interior do ambiente. Esta redução, no caso da arquitetura dos Hotéis econômicos, que por serem ocupados principalmente durante a noite (quando não há luz natural), pode ser interpretada como não prejudicial às condições de conforto e desempenho energético do ambiente.

\subsection{Opção pelo condicionamento artificial}

Para as condições climáticas de São Paulo, apresentadas anteriormente na seção 4.3, a opção pelo condicionamento artificial resume-se em três frentes distintas:

$1^{\text {a }}$. A escolha e o dimensionamento dos SAC, de forma mais adequada as necessidades do edifício;

$2^{\circ}$. A redução do ganho de carga térmica, seja pela envoltória, seja pelo aprimoramento de equipamentos e adequação no uso de acordo com as necessidades e/ou exigências;

$3^{\circ}$. A definição das características construtivas mais adequadas para o melhor desempenho do SAC, com menos taxa de infiltração.

\subsubsection{Os SACs mais eficientes}

O sistema de ar condicionado (SAC) deve estabelecer a melhor relação de custo benefício entre o consumo de energia e o conforto dos usuários. Nesse aspecto, a avaliação preliminar das necessidades, o diagnóstico climático e o perfil de ocupação são determinantes para a integração entre o SAC mais adequado e o projeto de arquitetura.

É importante verificar que a operação deve ser eficiente ao máximo, atendendo às exigências de conforto e eficiência do sistema. Merecem destaque os seguintes itens:

- Uso de equipamentos mais eficientes, não apenas dos equipamentos de climatização de ar, mas também de lâmpadas e equipamentos que gerem menos carga térmica no ambiente; 
- A manutenção deve ser programada e documentada, para que possa ser verificada alguma falha no funcionamento do sistema;

- O controle do ambiente deve ser efetivo, evitando que o sistema seja acionado quando alguma janela estiver aberta, dificuldade que pode ser sanada com a instalação de sensores de abertura nas janelas;

- O equipamento deve ter seu uso otimizado, trabalhando na sua capacidade de maior aproveitamento, e atendendo as condições de conforto estipuladas em projeto.

Todos os fabricantes de ar condicionado incluem, no manual técnico do equipamento, a eficiência do sistema, conhecida como COP $^{16}$ (do inglês: Coeficiente of Performance). Para os sistemas indiretos, utiliza-se também um valor integrado de carga parcial (sigla do inglês, IPVL) ${ }^{17}$. Ele representa um valor médio do desempenho do Chiller ao longo de um ano em operação nas várias condições de carga parcial, com condições de temperatura de água (ou ar, dependendo do tipo de refrigeração do sistema) na entrada do condensador (CLETO e HERNADEZ NETO, 2006).

Na regulamentação energética de edifícios (atualmente voluntária) que deverá entrar em vigor em 4 ou 5 anos, o SAC é um dos três itens que, juntamente com a iluminação e a envoltória, foram contemplados no documento. Segundo essa regulamentação, são considerados os SAC com COP dos sistemas de janela e split, com selo de etiquetagem A e B do PROCEL, para o âmbito nacional. No caso dos sistemas indiretos, utilizam-se como valores de referência os valores da norma ASHRAE 90.1 de 2004, já que, no Brasil, ainda não há laboratórios equipados para fazer a certificação desses equipamentos.

Dentre alguns itens relevantes para melhorar a eficiência do sistema, merece destaque a possibilidade de escalonamento dos Chiller, que pode representar uma operação do equipamento em seu "ponto ótimo", conforme indica a IL.47.

No caso dos sistemas de condensação a água, a temperatura da água de condensação, também deve ser devidamente analisada, para que o sistema opere de maneira mais eficiente, podendo representar uma redução no consumo global de 1 até 5,8\% (verão e inverno, respectivamente).

\footnotetext{
16. COP: segundo a ASHRAE 90.1 é a razão da taxa de calor removido pela taxa de energia consumida por um sistema completo de refrigeração, ou uma porção específica deste sistema completo de refrigeração.

17. IPVL: é uma média ponderada de eficiência energética do SAC, número de um dígito baseado em COP ou $\mathrm{kW} / \mathrm{ton}$.
} 


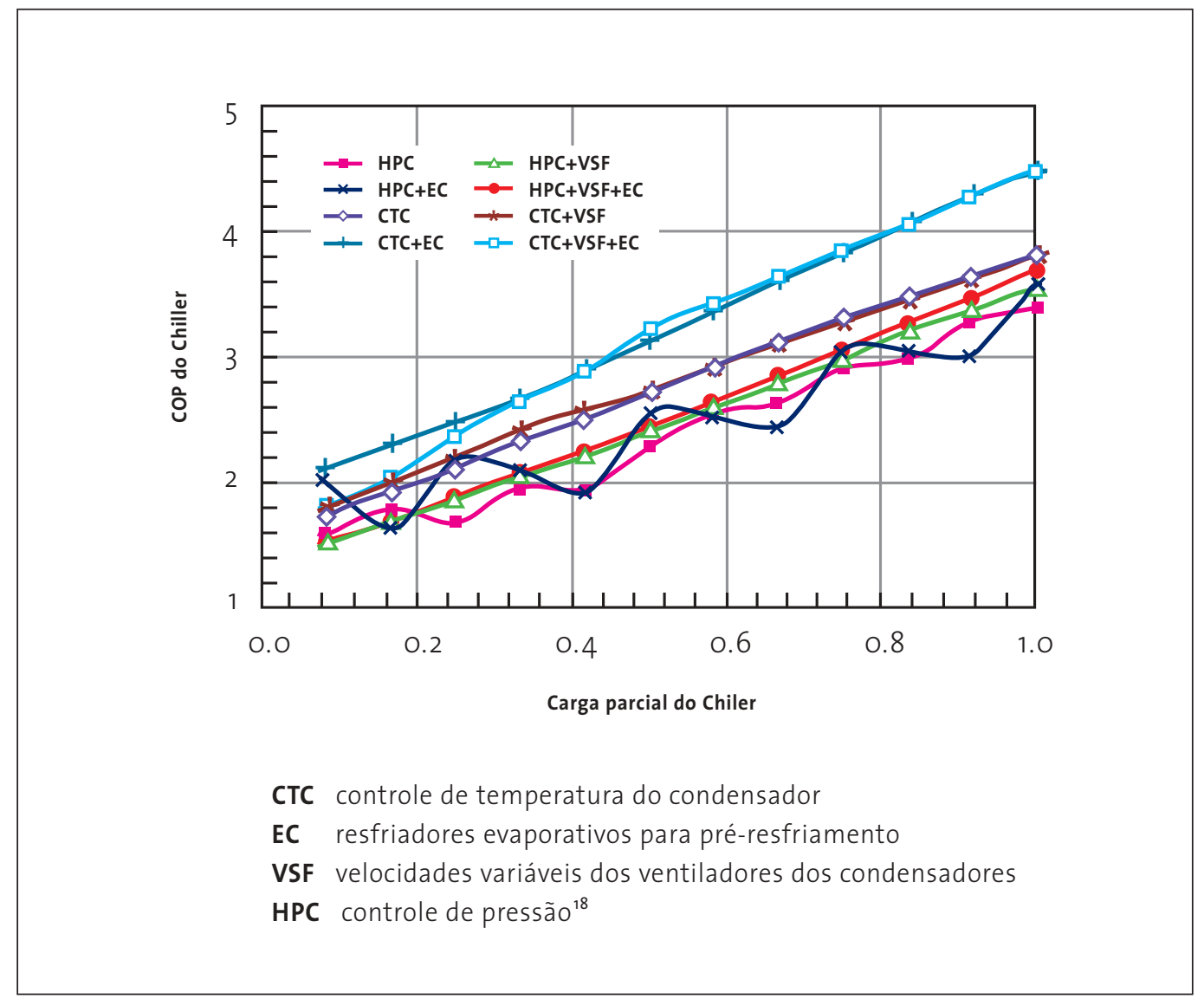

Ilustração 47: Curva de eficiência de um chiller com várias combinações de condensadores pela carga parcial do chiller, considerando a temperatura externa de $30^{\circ} \mathrm{C}$ Fonte: YU, F.W., CHAN, K.T, 2006.

É importante destacar que o posicionamento dos sensores pode determinar tanto o desconforto dos usuários quanto a ineficiência do sistema, caso estejam posicionados muito distantes das pessoas.

A variação da temperatura é estratificada devido à diferença de pressão e temperatura do ar. Em locais com pé direito alto, mais de 4 metros, recomenda-se que o sensor esteja localizado próximo do nível das pessoas, para evitar desconforto aos usuários e ineficiência do sistema.

Com todos esses elementos, é fundamental que se defina uma hierarquia de valores, baseada em critérios que seguem as necessidades de cada projeto exige.

18. Determina que um número dos estágios dos ventiladores dos condensadores seja mantido no mínino para manter a temperatura de condensação para variar perto do máximo valor determinado. 


\subsubsection{Critérios para a escolha do SAC}

A escolha de um SAC a ser utilizado em um hotel deve ser bastante criteriosa, devido às peculiaridades do seu uso, à interferência no conforto ambiental, além da complexidade de sua operação e manutenção. Dentre os principais elementos a serem considerados na seleção do SAC, destacam-se os seguintes:

1. O controle da qualidade do ar interno;

2. Os custos iniciais de implantação;

3. O desempenho do sistema;

4. O desempenho acústico;

5. O posicionamento dos equipamentos na parte interna e, ou externa;

6. A interferência estética na fachada do edifício;

7. A necessidade de espaços para casa de máquinas e tomada de ar externo; A seguir, estaremos descrevendo sobre cada um deles.

\section{O controle da qualidade do ar interno}

A qualidade do ar é um elemento fundamental para a adequação do sistema em um ambiente. Segundo a Portaria $n^{\circ} 3.523$ (ANVISA, 1998), para minimizar o risco potencial à saúde dos usuários com permanência prolongada em ambientes climatizados artificialmente, deve-se considerar os três principais itens:

a. Que haja um plano de manutenção, operação e controle dos sistemas;

b. Que parâmetros físicos considerados no projeto atendam as condições previstas para o ambiente ou edifício;

c. Que a composição física e biológica do sistema atenda às necessidades previstas.

Considerando ainda a preocupação com a saúde dos usuários de ambientes climatizados artificialmente, a Associação Nacional de Vigilância Sanitária (ANVISA) regulamentou formalmente, por meio da Resolução N9 (ANVISA, 2003), quais particulados suspensos no ar em um ambiente climatizado devem ser evitados e controlados, conforme valores mínimos de renovação de ar, de acordo com o uso do ambiente. São eles: fungos, protozoários, vírus, algas, polens, poeira, óxido de carbono, dióxido de nitrogênio e formaldeído (popularmente conhecido como a bactéria legionela).

\section{Os custos iniciais de implantação}

A complexidade das instalações de cada sistema varia desde sistemas que necessitam de dutos de ar, de tubulação para circulação de gás refrigerante, de tubulação para circulação de água gelada, até os mais simples, que exigem um único ponto de força elétrica e uma saída para o ar exterior. A conseqüência dessa 
grande variação de complexidade reflete diretamente nos custos de implantação de cada SAC, bem como na necessidade de previsão de espaços e adequação da arquitetura do edifício desde sua concepção inicial de projeto.

Segundo Jabardo (1989), o elevado custo inicial desses componentes pode ser compensado por significativas reduções nos custos operacionais. Por esse mesmo motivo, deve-se avaliar o ciclo de vida do edifício, como foi apresentado na IL.1, por Jones (1998). Dessa forma, serão também considerados os períodos de utilização e o desempenho de cada sistema, este último apresentado a seguir.

\section{O desempenho do sistema:}

Para Jones (1998), o consumo de energia em um ciclo de vida de 60 anos dos edifícios é muito maior no período de operação e, por esse motivo, tendo como foco os SAC, quanto mais eficiente na fase de operação, menor o consumo de energia elétrica.

No Brasil, desde 1993, o selo PROCEL vem sendo aplicado aos SAC para identificar a eficiência energética dentro da sua categoria. Esse mecanismo foi criado pela Eletrobrás, para dar suporte à Lei de Eficiência Energética ( $\left.N^{0} 10.296 / 2001\right)$, tendo sido regulamentado pelo INMETRO.

Dentre os equipamentos categorizados pelo PROCEL, entre outros, os SAC de expansão direta, ou seja, os chamados ar condicionados de janela e os sistemas Split são os únicos SAC avaliados dessa forma no Brasil e classificados em níveis de $A$ (mais eficiente) a $E$ (menos eficiente).

Já os sistemas de expansão indireta, como resfriado a ar ou a água, exigem laboratórios específicos, ainda inexistentes aqui, e por isso mesmo, quando necessitamos do COP desses equipamentos, baseamo-nos nas tabelas de eficiência da norma ASHRAE Standard 90.1 (2004), que consta também os valores de IPVL.

Esses critérios são os mesmos que vem sendo adotados na regulamentação para etiquetagem voluntária de nível de eficiência energética de edifícios Comerciais, de Serviços e Públicos, desenvolvido pelo PROCEL Edifica em setembro de 2006.

\section{4. $O$ desempenho acústico:}

A complexidade das instalações dos SAC compostos por motores e ventiladores tradicionalmente geradores de ruídos exige que o projeto do sistema seja criteriosamente executado, para assim evitar o desconforto acústico dos usuários tanto no interior quanto no exterior dos ambientes climatizados. Refere-se, neste segundo caso, ao posicionamento de casas de máquinas no topo de edifícios, com grandes ventiladores, ou até a sistemas de refrigeração a água, que geram níveis de ruído elevados que facilmente se propagarão pelo ar para as edificações vizinhas, causando desconforto acústico. 
As principais fontes de ruído do ar-condicionado são:

- Os motores e ventiladores;

- As turbulências devido ao fluxo do ar;

- Os ruídos de origem exterior que penetram no sistema devido às possíveis frestas.

Já em 1972, Del Carlo destacou que os construtores eram capazes de controlar suficientemente bem as instalações de ar-condicionado para que elas não produzissem e nem transmitissem níveis de ruídos indesejáveis.

\section{O posicionamento dos equipamentos na parte interna e, ou externa:}

Dependendo da complexidade dos sistemas pode facilitar ou não a localização mais adequada dos equipamentos geradores de ruído, como motores e ventiladores.

No caso dos sistemas diretos, também conhecidos como domésticos, o posicionamento dos motores ao lado dos ventiladores é determinante na qualidade do sistema em geral e, por este motivo, muitas vezes não são adequados para o uso em UH de Hotéis e em residências, apesar da facilidade na instalação.

Quando falamos dos sistemas indiretos, devemos nos preocupar com os espaços mais adequados a eles, buscando preferencialmente isolá-los das áreas ocupadas, ou num andar técnico ou em garagens. No entanto, a necessidade de tomada de ar externo muitas vezes determina que os ventiladores e motores principais posicionem-se no topo dos edifícios, já que os terrenos tendem a ser cada vez menores e a ocupação desses equipamentos acaba sendo destinada para locais menos "nobres" do edifício.

\section{A interferência estética na fachada do edifício:}

O partido arquitetônico e o sistema de ar condicionado devem se inter relacionar, preferencialmente, desde a concepção inicial do projeto. Evans (2007) já destacou o quanto as decisões tomadas nas etapas iniciais da concepção do projeto auxiliam para o melhor desempenho e custo da solução adotada, como foi apresentado na TAB.7, na página 52.

A localização destes sistemas no edifício é definida tanto por suas necessidades espaciais e estruturais quanto pela estética do edifício.

Os SAC de expansão direta (janela e split) não exigem alterações na estrutura do edifício devido ao baixo peso do equipamento. Os de janela interferem diretamente na estética da fachada, pois os condensadores devem ficar externos à fachada, enquanto que os sistemas split possuem um pouco mais de flexibilidade do que os anteriores porque os condensadores são independentes dos evaporadores, que devem ficar no interior dos ambientes. Quando o uso destes siste- 
mas for definido nas primeiras etapas do projeto de arquitetônico, soluções como a apresentada na IL.9 (p.25)mostram pouca interferência estética na fachada.

Atualmente, devido a esta flexibilidade dos sistemas split, muitos fabricantes vem desenvolvendo modelos com evaporadores mais compactos e com diversos acabamentos com cores diferentes buscando uma interferência menor também no interior dos ambientes.

Os sistemas de expansão indireta (condensação a água ou a ar) interferem de forma mais agressiva na arquitetura do edifício devido ao peso dos equipamentos, a vibração de alguns dos seus componentes e a necessidade de tomada de ar externo. Alguns componentes como o Chiller podem ser posicionado no subsolo, reduzindo a necessidade de uma estrutura mais robusta, mas, por outro lado, exigindo outros equipamentos, como motores para bombear a água resfriada para os andares superiores.

Considerando o edifício como um conjunto único, exige-se muito mais do que apenas o planejamento conjunto de espaços para os componentes do SAC, já que influenciam na arquitetura do edifício e no desempenho do mesmo.

O papel do arquiteto é também criar elementos que contribuam para a redução dos ganhos de calor e para uma melhor adequação do edifício ao seu uso, tirando assim proveito de fontes passivas para obtenção de conforto. Na IL. 48 estão alguns edifícios comerciais em São Paulo que possuem janelas lacradas, sem opção de abertura, e que têm como uma das características padrão fachadas com peles de vidro e sistemas de expansão indireta. Este modelo de arquitetura simplifica o papel do arquiteto na medida em que a não integração dos sistemas passivos reduz as alternativas de projeto que poderiam, consequentemente, resultar em SAC com capacidades menores.

Neste aspecto, a composição das fachadas e dos caixilhos, além da forma e orientação, é fundamental para uma melhor arquitetura. Nos casos em que o sistema de ar condicionado deve ser utilizado, é preciso adequá-lo a essa mesma fachada, integrando-o com a arquitetura.

A tendência do mercado é de aceitar qualquer padrão de arquitetura "internacional”19 e não adequá-lo às condições climáticas do local onde o edifício está inserido. Uma das forças do estilo internacional está relacionada ao fato de que as soluções de projeto eram indiferentes ao local, à cidade e ao clima. Nas Ils. 49 e 50, vêemse exemplos de Hotéis de redes internacionais, situados na cidade de São Paulo.

19. Estilo "internacional": o estilo feito sem referência à história local e na arquitetura vernacular. Trata-se de edifícios idênticos em todo o mundo (WIKIPEDIA, 2007). 


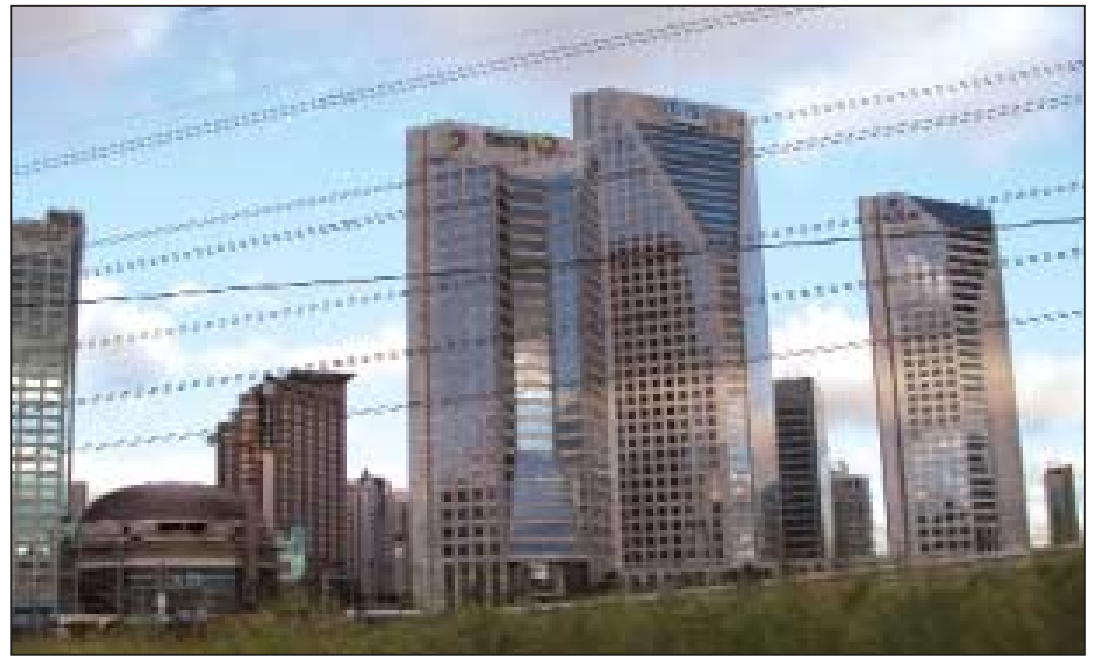

Ilustração 48: Exemplos de edifícios de escritório (Torre Norte) e hotel na cidade de São Paulo com arquitetura "internacional”.

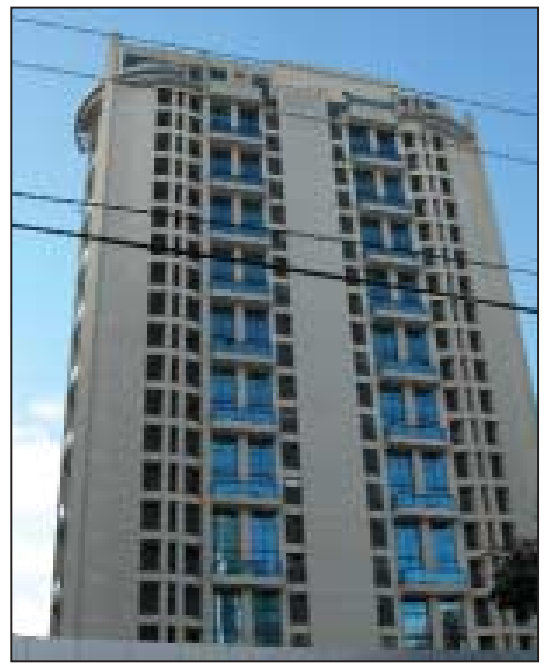

Ilustração 49: Exemplos de hotel em São Paulo: com vidros refletidos e varandas

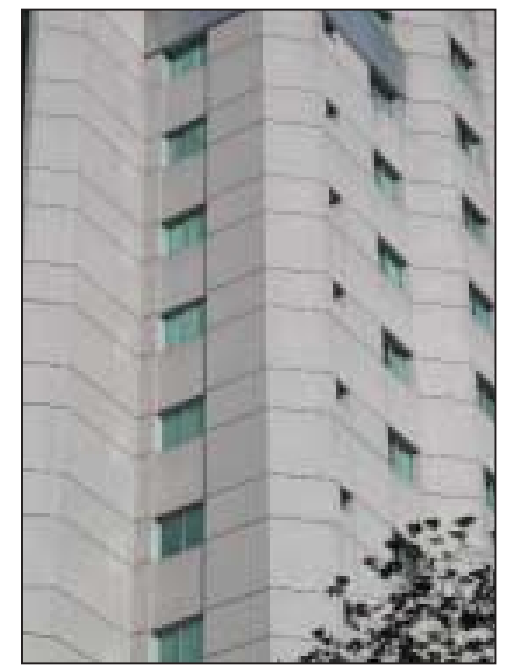

Ilustração 50: Exemplos de hotel com vidros verde e cortina black out (internas)

\section{A necessidade de espaços amplos para casa de máquinas e tomada de ar:}

Sabe-se que o custo do ciclo de vida de um edifício é elemento fundamental para a avaliação da adoção adequada de materiais e sistemas, tais como o SAC. A tomada de ar externo, o peso dos equipamentos, o ruído gerado por seus componentes, a qualidade do ar, entre outros elementos, devem ser definidos pensando no conforto dos usuários e na eficiência do sistema, que se reflete diretamente no consumo de energia e, conseqüentemente, no desempenho do edifício como um todo. 
Os SAC com capacidades maiores são, na sua maioria, os sistemas de expanção indireta. Eles exigem uma casa de máquinas para posicionar os equipamentos, sendo que um deles é responsável para a tomada do ar externo que é insuflado no sistema para resfriar e renovar o ar dos ambientes internos. A definição do local mais adequado para ele deve ser decidida tanto pelo arquiteto, que pode integrar as grelhas de entrada de ar na arquitetura do edifício, quando pelo engenheiro do ar condicionado, que busca um posicionamento adequado para manter a eficiência do sistema. Destaca-se também duas preocupações a mais:

1. A segurança e proteção das grelhas (evitar entrada de bichos e também vandalismo);

2. A qualidade do ar que será insuflado (evitar posicionar em áreas de garagem, com alta concentração de $\left.\mathrm{CO}_{2}\right)$.

Diante de todos estes elementos do SAC descritos nesta seção, é importante destacar que não existe um sistema ideal, mas sim o mais adequado para o uso do edifício, conforme suas características e a exigência do seu uso.

$\mathrm{Na}$ escolha do sistema mais adequado as necessidades do edifício é fundamental que se estabeleça uma hierarquia de valores baseada em critérios previamente definidos tais como: nível de ruído (interno e externo), qualidade do ar,interferência na arquitetura (externa, interna), peso dos equipamentos, espaço ocupado (casa de máquinas), eficiência do sistema, manutenção e custo de instalação.

Cada projeto, de acordo com as necessidades do empreendedor, do arquiteto ou até mesmo do uso a que se destina o edifício, determina qual destes critérios deverá ter peso maior para a escolha do equipamento, sendo que algumas características, integradas com a arquitetura, atendem de uma forma melhor.

\subsubsection{Dimensionamento da capacidade do SAC}

Um fator importante a ser considerado na escolha do sistema é a capacidade de resfriamento (ou aquecimento) necessária que cada sistema deve possuir para atender à necessidade da carga térmica, que representa o quanto de calor deverá ser retirado (ou cedido) do ambiente, dada sua área e ganhos de calor durante o uso.

Os procedimentos de cálculo da carga térmica estão descritos na norma ASHRAE 90.1 (2004). Nos cálculos, são considerados os ganhos provenientes da envoltória, das pessoas, dos equipamentos e da iluminação. No dimensionamento do SAC, incluem-se nesses ganhos os da carga térmica da serpentina e Chiller. 
A seguir, estão enumeradas algumas das características que devem ser estudadas adequadamente, tanto pelo arquiteto quanto pelo projetista dos SAC, para que o dimensionamento do sistema atenda à tipologia do edifício hoteleiro.

a) Estudo das áreas condicionadas:

Na definição do sistema a ser utilizado, devem-se separar as áreas e os períodos a serem condicionados por dia e mês. No caso dos Hotéis Econômicos, a ocupação dos quartos em relação aos outros ambientes, tais como recepção, restaurantes ou salas de evento, por exemplo, é bastante diferente.

Nas UH dos Hotéis Econômicos, a ocupação se dá principalmente no período noturno (BUORO, et. al, 2003; MESQUITA, 2006), porém nas outras áreas ela tende a ser mais variável, desde as 24 horas do dia e 365 dias por ano (na recepção) até a ocupação esporádica (no caso das áreas destinadas a eventos).

Além disso, a forma de ocupação ao longo dos doze meses do ano é diferente: no caso do setor de eventos, é bastante variável (seguindo a flexibilidade até mesmo do layout, que geralmente pode integrar várias salas pequenas em uma sala única maior); nos apartamentos, a ocupação pode ser de 1 a 3 pessoas, consistindo em pouca geração de carga térmica devido aos equipamentos e iluminação, resultando em pequenas variações de usos ao longo do ano. Estas variações acontecem de acordo com a taxa de ocupação do Hotel, e das salas de eventos.

O padrão de uso e o período de ocupação são diferentes e, portanto, recomendase que o sistema utilizado também seja. O máximo aproveitamento de um sistema é decorrente do melhor dimensionamento deste para as suas condições de operação.

Dessa forma, o mais adequado seria separar os ambientes com cargas térmicas diferentes e dimensioná-los separadamente. Apesar disso, não se deve descartar a necessidade de realizar uma análise do conjunto: ou para verificar a possibilidade e o interesse em adotar um sistema único que possa atender aos dois casos, ou para verificar se a solução mais adequada seria mesmo estabelecer dois sistemas totalmente independentes para cada caso, ou complementares.

Partindo-se do princípio de que um edifício de hotel de categoria econômica possui apartamentos padronizados que representam a maioria da área condicionada de um hotel, o que determinará o valor total da maior parte da carga térmica do SAC do edifício será a somatória das unidades habitacionais (UH), consideradas para serem refrigerados com a carga térmica da serpentina e do chiller.

\section{b) Distribuição das potências:}

O projeto arquitetônico da maioria dos hotéis econômicos tem planta de forma predominantemente retangular, com apartamentos em duas faces e corredor de circulação no eixo central das UH. 


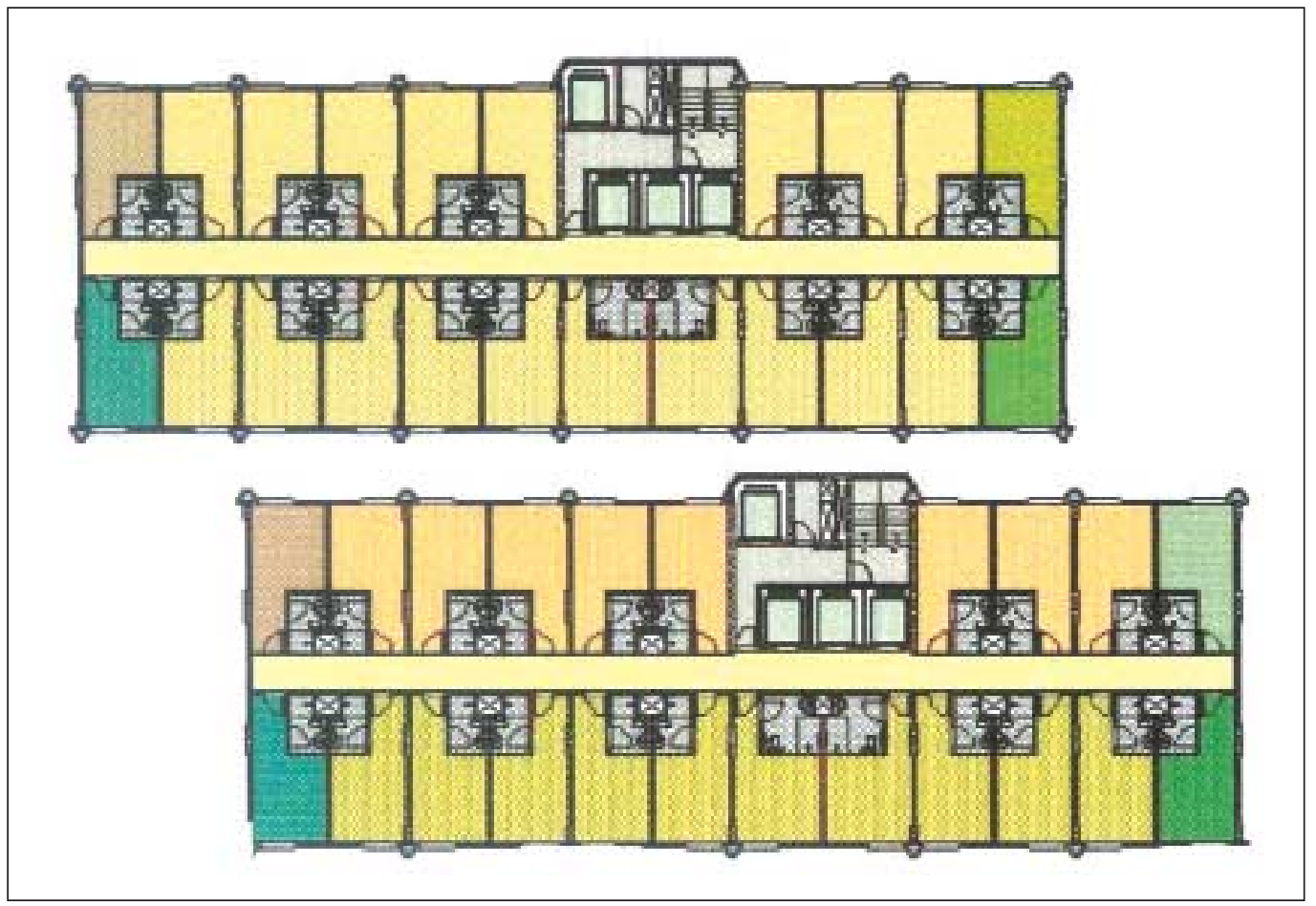

Ilustração 51: Plantas do $1^{\circ}$ ao $12^{\circ}$ pavimento (lado esquerdo) e do $13^{\circ}$ pavimento (lado direito) em estudo de Hotel Econômico, com indicação de cores diferentes de acordo com a diferença na carga térmica. Fonte: BUORO, De BENEDETTO, MIURA, 2003.

Para o dimensionamento adequado da carga térmica dos apartamentos, devem-se separar todas as faces com diferentes orientações, assim como o último pavimento, que tende a sofrer maior ganho de calor devido à cobertura. Em muitos casos, ela não tem proteção solar e recebe radiação direta, aquecendo por condução a laje e, com isso, necessitando de mais toneladas de refrigeração (TR) para resfriar este último pavimento.

Na pesquisa em Hotel Econômico de rede internacional de Buoro, De Benedetto e Miura (2003), foi realizado o cálculo de carga térmica do SAC. Neste dimensionamento foram considerados, separadamente, os apartamentos do último pavimento tipo bem como a separação das UH nos que possuíam orientações diferentes, por eles possuírem diferenças no cálculo da carga térmica, conforme pode ser visto da IL.51.

Em um hotel de categoria econômica em São Paulo, com janelas lacradas, segundo Buoro et. al (2004), o valor médio de carga térmica por UH foi calculado em 0,8 TR, variando com UH orientadas a Leste e 0,4TR, até UH no último pavimento, orientadas a Nordeste, com 1 TR. Deve-se ressaltar que as janelas lacradas forçam o uso do SAC mesmo quando este poderia não ser necessário, seja pelas condições externas ou internas, o que resulta em consumos de energia ainda mais elevados de SAC. 


\section{c) Qualidade do ar:}

Há alguns anos, quando as redes nacionais e internacionais foram aumentando a sua competitividade no mercado hoteleiro, era comum existirem andares inteiros reservados para apartamentos de fumantes.

Diversas leis e decretos foram criados no município de São Paulo para que essa separação ocorra principalmente nas áreas públicas, restaurantes, bares, bem como nos hotéis. A tendência atual dos hotéis é de reduzir essas áreas destinadas aos fumantes. Além disso, nas áreas comuns, já é comum separar os ambientes para fumantes e não fumantes, com intuito também de melhorar a qualidade do ar para todos.

Nas redes hoteleiras, no caso dos ambientes privativos, as UH, a intenção não era apenas de criar um espaço para o público fumante, mas principalmente de separá-lo dos demais espaços, para facilitar a manutenção e a limpeza dos mesmos. O ambiente para fumantes exige uma manutenção maior, que resulta em trocas mais freqüentes de materiais de acabamento, nova pintura, bem como na limpeza mais freqüente.

Atualmente sabe-se que, nas redes hoteleiras, a porcentagem de fumantes vem diminuindo nos últimos 10 anos, e desde a década de 90, os hotéis já vêm se adequando à nova realidade, desse modo destinando um número cada vez menor de UH exclusivamente para fumantes.

Isso interfere diretamente no dimensionamento do SAC. Segundo as tabelas da Resolução Normativa número 9, RE Nº9 (ANVISA,2003), em ambientes com usuários fumantes pode haver a concentração de óxido de carbono e dióxido de nitrogênio e deve-se considerar uma renovação adequada para a mistura e eliminação desses agentes, com renovação total de ar.

Dessa forma, recomenda-se que a renovação do ar nos apartamentos de fumantes seja de $100 \%$, sem que haja mistura do ar de retorno dos apartamentos de fumantes com o dos não fumantes. Caso contrário, o ar de todo o sistema seria contaminado pelos poluentes provenientes dos apartamentos de fumantes.

Apesar de esta constatação ser nítida, a maioria dos projetos de SAC de expansão indireta em hotéis não considera a separação de ar de saída e, portanto, todas as UH acabam sendo contaminadas pelo ar de retorno das UH proveniente dos fumantes, prejudicando assim a qualidade do ar de toda área climatizada.

\section{d) Sistema de distribuição do ar:}

A qualidade do ar sofre também influência da forma de distribuição dos sistemas de ar condicionado. O dimensionamento adequado do número de trocas por hora e a avaliação da velocidade do ar, de acordo com os posicionamentos 
dos insufladores de ar, é um dado fundamental para não causar desconforto para os usuários.

Destaca-se a importância de não criar o chamado efeito draft ${ }^{20}$. As normas ASHRAE 55 (2004) e ISO 7730 (1994) estabelecem os limites recomendados para: a velocidade do ar (que varia de acordo como a atividade); a diferença de temperatura do ar vertical (entre os pés e a cabeça) e a assimetria de radiação.

\section{e) Definição da temperatura de projeto:}

O dimensionamento do SAC baseia-se na temperatura de projeto que foi definida no método de cálculo de desempenho térmico energético de AKUTSU (1998), como a média das máximas dos últimos 15 anos. Como o acesso a essa quantidade de dados climáticos nem sempre é possível, e com os relatos científicos de que as temperaturas globais estão subindo (IPCC, 2007), trabalhos recentes, tais como De Benedetto (2006), têm utilizado as médias das máximas dos últimos anos, sendo de, no mínimo, 5 anos.

Os edifícios da categoria de hotéis econômicos caracterizam-se por possuírem ocupação mínima de 60\% e ocupação em mais de $80 \%$ prioritariamente no período noturno (BUORO, et.al,2003 e MESOUITA, 2006). Dessa forma, sabe-se que projetistas de SAC para hotéis recomendam que a temperatura de projeto para os cálculos do dimensionamento do SAC seja o valor da temperatura mais quente da noite do local onde será implantado, e não do dia, como é feito no método de calculo do desempenho térmico desenvolvido por Akutsu (1993). Merece destacar também que parte do que acontece à noite é reflexo da temperatura máxima diária, da inércia térmica do edifício e das características do seu entorno.

Quando for utilizado o dia crítico, ou seja, a noite mais quente, ela terá uma representatividade muito pequena ao longo do ano. Como essa temperatura deverá ocorrer num número muito pequeno de dias do ano, o valor tende a ser superdimensionado neste caso. Sendo assim, no dado de temperatura de projeto, recomenda-se utilizar a média da noite mais quente dos últimos cinco anos (no mínimo).

Caso o valor da temperatura de projeto seja proveniente de um dia crítico e não a média das máximas temperaturas, pode haver um superdimensionamento no sistema. Ocorrendo isso, alguns projetistas, os mais acostumados com o projeto do sistema para Hotéis Econômicos, recomendam que seja considerada a porcentagem de ocupação; no caso dos econômicos, usa-se o valor de 60\% (ocupação

20. Draft: segundo a norma ASHRAE 55 (2004) trata-se de um resfriamento local indesejável no corpo humano, causado pelo movimento do ar. 
mínima) como referência para descontar do valor final. Isso funcionaria como se a ocupação mínima fosse capaz de atender à temperatura máxima da noite mais quente do ano do dia crítico.

Essas recomendações foram levantadas por meio de entrevistas com engenheiros de ar condicionado que dimensionam os sistemas para os hotéis de uma rede hoteleira internacional. Segundo eles, esse dimensionamento atende às necessidades dos hotéis e não gera superdimensionamento de equipamentos nem desconforto no período mais quente e com ocupação acima de $60 \%$. Mesmo porque, quando existe a opção de abertura de janelas, nas condições climáticas da cidade de São Paulo, a ventilação é a estratégia passiva mais representativa para os meses mais quentes; em um edifício adequado às condições climáticas, muitos hóspedes não utilizarão o SAC. Isso ocorre por diversos motivos. Os mais comuns seriam:

1. Nem todas as pessoas utilizam o SAC nos apartamentos, ou porque o edifício tem uma arquitetura compatível com o clima e por isso a sensação térmica do ambiente é agradável na maior parte do tempo, nos limites do conforto, ou por problemas de saúde (porque alguns usuários são alérgicos ao SAC).

2. As temperaturas que os usuários determinam no acionamento do SAC (os chamados set point) variam de pessoa a pessoa, de acordo com suas características físicas, metabolismo, clo e aclimatação, entre outros, e por isso muitos usuários podem optar pela a ventilação natural ou mecânica, também porque a sobreposição de situações dos dias de temperaturas mais altas com a alta taxa de ocupação pode ocorrer proporcionalmente muito pouco, ao longo do ano.

\section{e) Redução de Carga térmica no interior do ambiente:}

Dentre as várias alternativas para tornar o SAC mais eficiente, a redução de carga térmica pode ser considerada a mais comumente praticada no mercado. Assim como foi descrito anteriormente na seção 4.6, na opção pelo condicionamento natural, as estratégias ali descritas para a redução da carga térmica no interior do ambiente são as mesmas a serem aplicadas para a opção pelo condicionamento artificial, com exceção de duas delas: as características construtivas e as aberturas.

Com relação às aberturas, enquanto que no condicionamento natural o dimensionamento adequado está relacionado ao máximo proveito das condições externas naturais (ventilação) no condicionamento artificial estas condições são desprezíveis, já que quanto menor a taxa de infiltração das aberturas, melhor será o desempenho do SAC. 


\subsection{Opção pelo modo misto: natural + artificial}

Entende-se como modo misto um novo conceito que utiliza apenas os sistemas mecânicos quando o natural não é suficiente, possibilitando a redução no consumo energético com a redução do uso de SAC ao longo do ano todo.

A viabilidade deste novo conceito pautou-se na extensa pesquisa de De Dear, Brager e Cooper (1997), apresentada na seção 4.5, em que mais de 20 mil edifícios com SAC e Edifícios com ventilação natural (VN) foram estudados. Esta pesquisa resultou na revisão da norma ASHRAE 55 (2004), que anteriormente tratava apenas de edifícios climatizados artificialmente, mas passou a englobar novos critérios para a avaliação da opção do modo misto.

O elevado gasto com energia elétrica e as exigências energéticas das normas Européias (entre outras) favoreceram o aprimoramento da arquitetura de edifícios para o aproveitamento das condições naturais na maior parte do ano, e a adoção do modo misto de condicionamento. Os exemplos são mais comuns em edifícios de escritório, tais como os mais conhecidos edifícios do Commenzbank, Alemanha, e da Swiss Re, Inglaterra, ILs. 52 e 53, respectivamente. Os edifícios de escritório, em sua maioria, representam ambientes com muita geração de calor interno, seja pelo elevado número de pessoas, seja pelos equipamentos e sistema de iluminação. Com isto o modo misto tem sido utilizado para integrar desde a concepção inicial do projeto a adoção de estratégias que maximizem o aproveitamento das condições naturais e minimizem das artificiais.

Mesmo com condições climáticas mais desfavoráveis na Europa em geral, comparadas com as de São Paulo, e grandes amplitudes térmicas anuais, com invernos rigorosos, estes dois edifícios citados têm sido uma referência de projeto para esta opção de condicionamento. Ambos foram analisados, através de simulações termo-dinâmicas, desde a concepção inicial do projeto, o que os potencializa para um melhor resultado de arquitetura e desempenho energético ao longo do ano, e consequentemente durante o seu ciclo de vida.

A integração entre o sistema natural e artificial vem sendo pesquisado para as condições climáticas de São Paulo, e segundo De Benedetto (2007), o potencial de condicionamento do modo misto é elevado para as condições climáticas de São Paulo.

Segundo Arnold (1996), existe uma nova filosofia de projeto de deve ser incorporada no projeto de arquitetura, apresentado na IL. 54 com a adaptação dos princípios de Olgyay (1963). Pode-ser verificar que aplicando as estratégias de projeto para o condicionamento natural pode-se reduzir as cargas nos sistemas mecâ- 


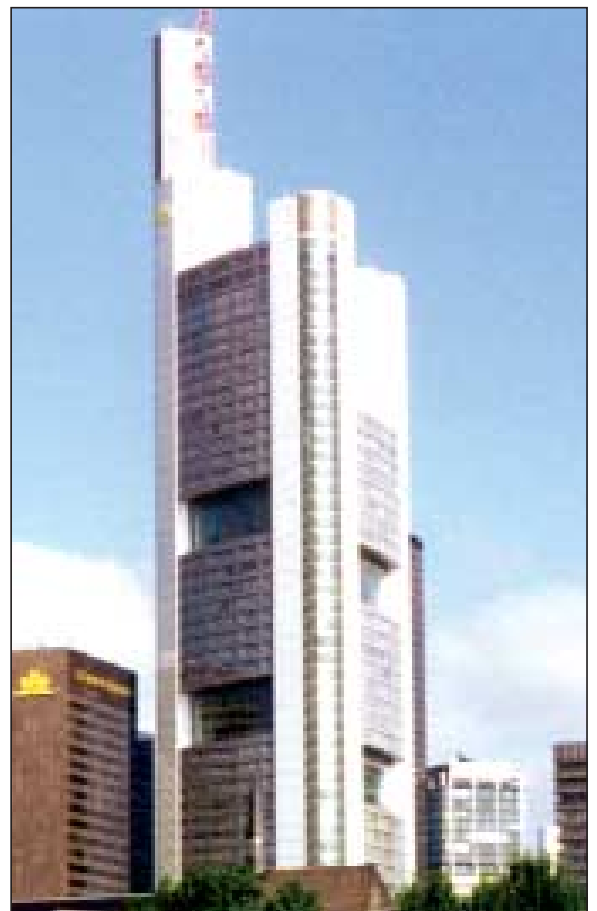

Ilustração 52: Edifício Commerzbank HQ, Frankfurt, Alemanha (Construído em 1997) Fonte: Joana Gonçalves.

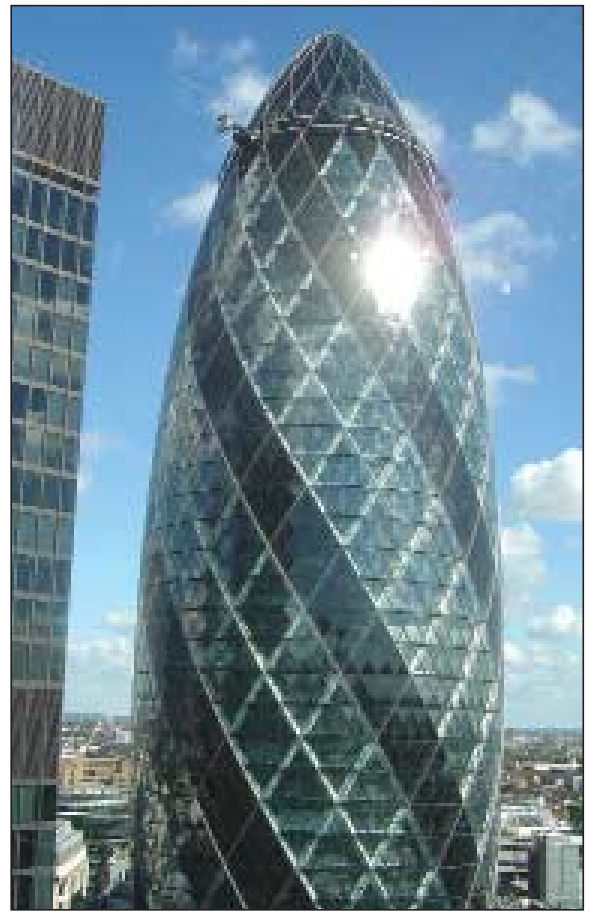

Ilustração 53: Edifício Swiss Re, Londres, Inglaterra (construído em 2004) Fonte: Mônica Marcondes.

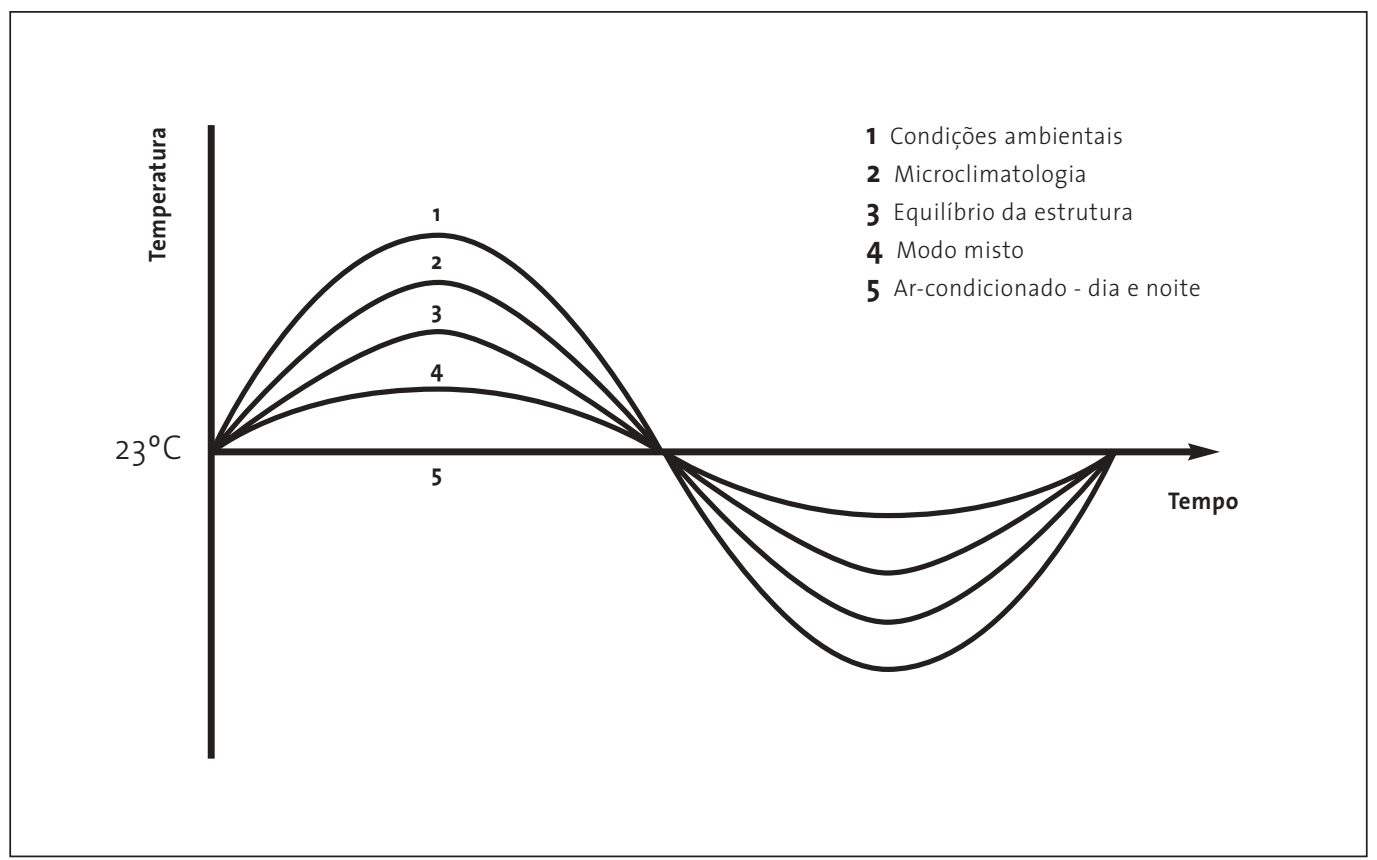

Ilustração 54: Os princípios da seleção das estratégias de projeto do comparadas com o modo misto Fonte: ARNOLD, 1996. 
nicos desde a variação das condições ambientais (curva 1) até a com o uso do SAC 24 horas (curva 5), para o equilíbrio balanceado da estrutura (curva 3) até a SAC 24 horas (curva 5). Se as condições internas levarem em conta os conceitos do modo misto (com oscilações de temperatura maiores do que as do condicionamento artificial, o desempenho pode ser ainda melhor, o equilíbrio balanceado da estrutura (curva 3) até o modo misto (curva 4).

Devemos destacar que quanto menores as amplitudes térmicas ao longo do tempo, melhor o desempenho de qualquer uma das três alternativas: condicionamento natural, artificial, ou condicionamento em modo misto.

Quando as temperaturas externas aumentam, a tendência é aumentar também a taxa de ventilação para que seja mantida a mesma condição interna. Isto pode ocorrer tanto aumentando as aberturas para ventilação natural ou utilizando de sistemas mecânicos.

Segundo Arnold (1996) as estratégias de projeto para o melhor aproveitamento do modo misto são:

1. Quantidade, tipo, localização, uso e controle das aberturas de VN;

2. Taxas de ventilação natural para cada modo utilizado (natural ou artificial);

3. Fluxo de ar, distribuição e controle dos sistemas mecânicos de ventilação;

4. Estimativa (se tiver) das taxas de resfriamento mecânico;

5. Alteração das condições que ativam o uso dos sistemas mecânicos.

A definição da temperatura de projeto para o modo misto (apresentada na seção 4.7.3 da opção pelo condicionamento artificial) deve ser dimensionada para o modo misto, e, portanto certamente ela oscilará ao longo das 24 horas diárias, e ao longo do ano, diferentemente do que acontece no condicionamento artificial.

Assim como foi descrito nas seções 4.6, e 4.7.2, a redução da carga térmica do ambiente para qualquer uma das opções de condicionamento melhora o desempenho da mesma. O grande desafio da arquitetura projetada para o modo misto é encontrar o ponto ótimo entre a área de abertura, WWR, e os sistemas construtivos.

Em resumo, o modo misto considera que as condições naturais levantadas no diagnóstico climático e avaliadas com as condições de ocupação determinem o uso do SAC, mas assumem que durante algum período do ano a VN pode ser utilizada ao invés do SAC e consequentemente o desempenho energético tende a ser melhor do que seria apenas com o uso do SAC.

Verifica-se portanto que a arquitetura tem papel fundamental tanto para a escolha da alternativa de condicionamento quanto para a definição de quais aspectos de projeto podem auxiliar no melhor desempenho do projeto com um todo. Estes aspectos estão apresentados na IL. 55. 


\begin{tabular}{|c|c|c|c|}
\hline Característica & $\begin{array}{l}\text { Condicionamento } \\
\text { Natural }\end{array}$ & $\begin{array}{l}\text { Condicionamento } \\
\text { Artificial }\end{array}$ & $\begin{array}{l}\text { Condicionamento } \\
\text { do modo misto }\end{array}$ \\
\hline Sistema Construtivo & $\begin{array}{l}\text {-Adequação climática } \\
\text { dos materiais par o } \\
\text { aproveitamento da } \\
\text { inércia térmica dos } \\
\text { sistemas construtivos } \\
\text { de acordo com o } \\
\text { período de ocupação }\end{array}$ & $\begin{array}{l}\text { Adequado para } \\
\text { que a Inércia não } \\
\text { aumente a carga } \\
\text { térmica durante o } \\
\text { período de ocu- } \\
\text { pação } \\
\text {-Isolamento dos } \\
\text { materiais para evi- } \\
\text { tar perdas }\end{array}$ & $\begin{array}{l}\text {-Adequação } \\
\text { climática dos mate- } \\
\text { riais para o } \\
\text { aproveitamento da } \\
\text { inércia térmica dos } \\
\text { sistemas constru- } \\
\text { tivos com isola- } \\
\text { mento dimensiona- } \\
\text { do adequadamente }\end{array}$ \\
\hline Aberturas (WWR) & $\begin{array}{l}\text { Tamanho, distribuição } \\
\text { e posicionamento } \\
\text { para o maior } \\
\text { aproveitamento das } \\
\text { condições naturais }\end{array}$ & $\begin{array}{l}\text { Janelas lacradas } \\
\text { (sem infiltração), } \\
\text { ou WWR ade- } \\
\text { quadas com caixil- } \\
\text { hos bem vedados } \\
\text { para reduzir taxa } \\
\text { da infiltração }\end{array}$ & $\begin{array}{l}\text { Com dimensiona- } \\
\text { mento adequado } \\
\text { para SAC (baixa } \\
\text { infiltração) e VN } \\
\text { (alta taxa de venti- } \\
\text { lação efetiva) }\end{array}$ \\
\hline
\end{tabular}

Ilustração 55: Comparação entre as diferenças principais do condicionamento natural, artificial e de modo misto.

\subsection{Aspectos Complementares}

Dentre todas as opções de condicionamento natural, artificial ou misto, diversas estratégias podem ser adotadas de forma a melhorar o desempenho energético da edificação.

A não utilização de sistemas ativos, ou seja, a opção pelo condicionamento natural ou de modo misto, pode exigir uma arquitetura mais complexa (com soluções integradas de projeto) do que no caso do uso integral do SAC. Isto porque neste caso no projeto arquitetônico - a forma da edificação, as características construtivas, o dimensionamento e posicionamento das aberturas e até mesmo a distribuição interna do lay out - são elementos que refletem diretamente no desempenho e no conforto dos usuários.

Edifícios com SAC podem manter o nível de conforto dos usuários, com temperaturas e umidades constantes o ano todo, independente da arquitetura. Porém, a capacidade do sistema e seu consumo energético é elevado e estão diretamente relacionadas a solução arquitetônica. 


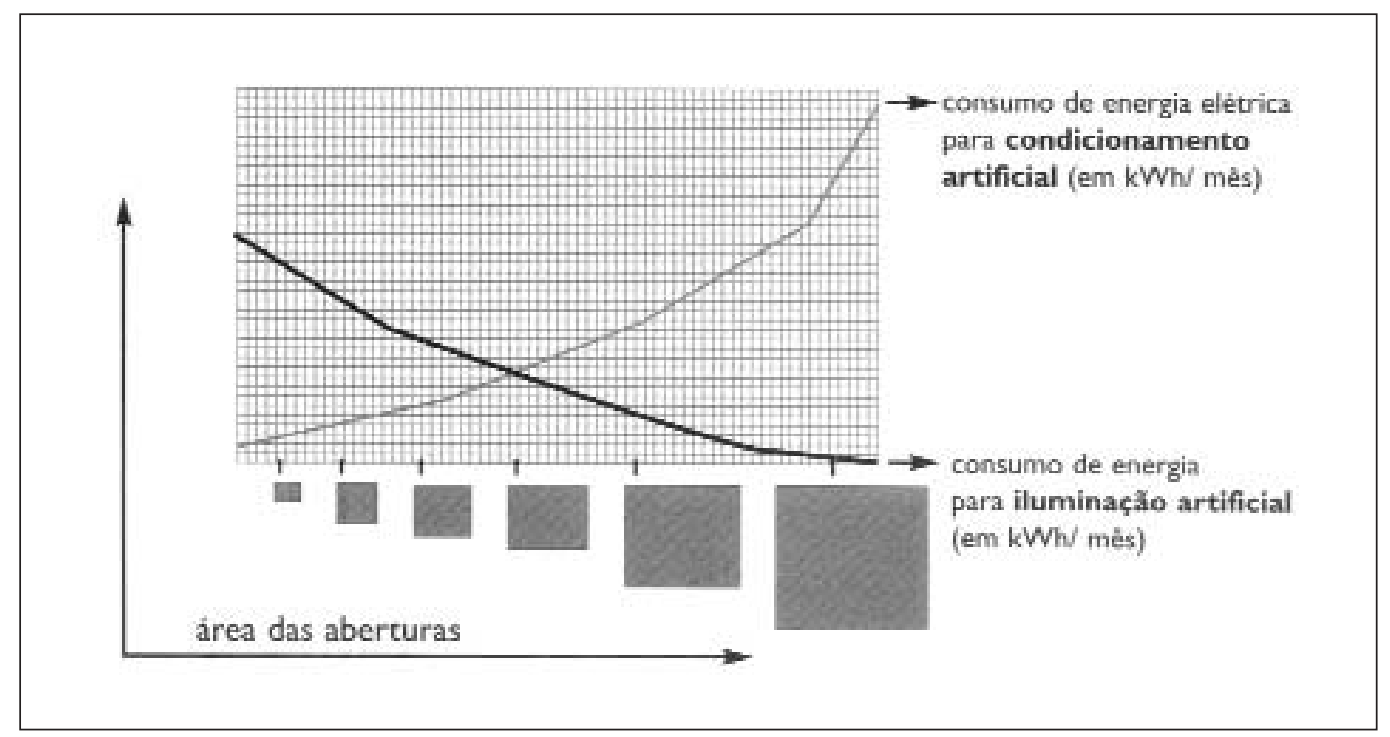

Ilustração 56: Relação das áreas de aberturas com consumo de energia elétrica para iluminação artificial (kWh/mês) e para o condicionamento artificial (kWh/mês)

Fonte: ALUCCI (2006)

\subsubsection{Iluminação}

A iluminação natural é um fator que depende tanto das condições climáticas, do tipo de céu (encoberto, parcialmente encoberto, ou claro), assim como das características das aberturas (dimensão e posicionamento), dos dispositivos de proteção solar como o "brise-soleil” (tipo e dimensões, quando houver), das características do ambiente (profundidade, largura, altura) e da refletância dos materiais de acabamento.

Com relação ao dimensionamento das aberturas, verifica-se na IL 56, que o aumento da área reduz proporcionalmente o consumo de energia para a iluminação artificial, porém aumenta o consumo para o condicionamento artificial.

$\mathrm{Na}$ iluminação natural o posicionamento e dimensionamento das aberturas e "brise-soleil" devem ser dimensionados e posicionados para maximizar o seu aproveitamento.

Em edifícios ocupados predominantemente no período comercial (das 9 horas às 18 horas), para São Paulo, mesmo no inverno quando a disponibilidade da luz natural é menor, ela deve ser aproveitada para que se utilize menor quantidade da luz artificial durante o dia, melhorando o desempenho energético do edifício.

Sobin (1981, apud BITTENCOUT e CÂNDIDO, 2005) apresenta na IL.57 o efeito da forma da abertura em função da direção do vento e da existência de prote- 


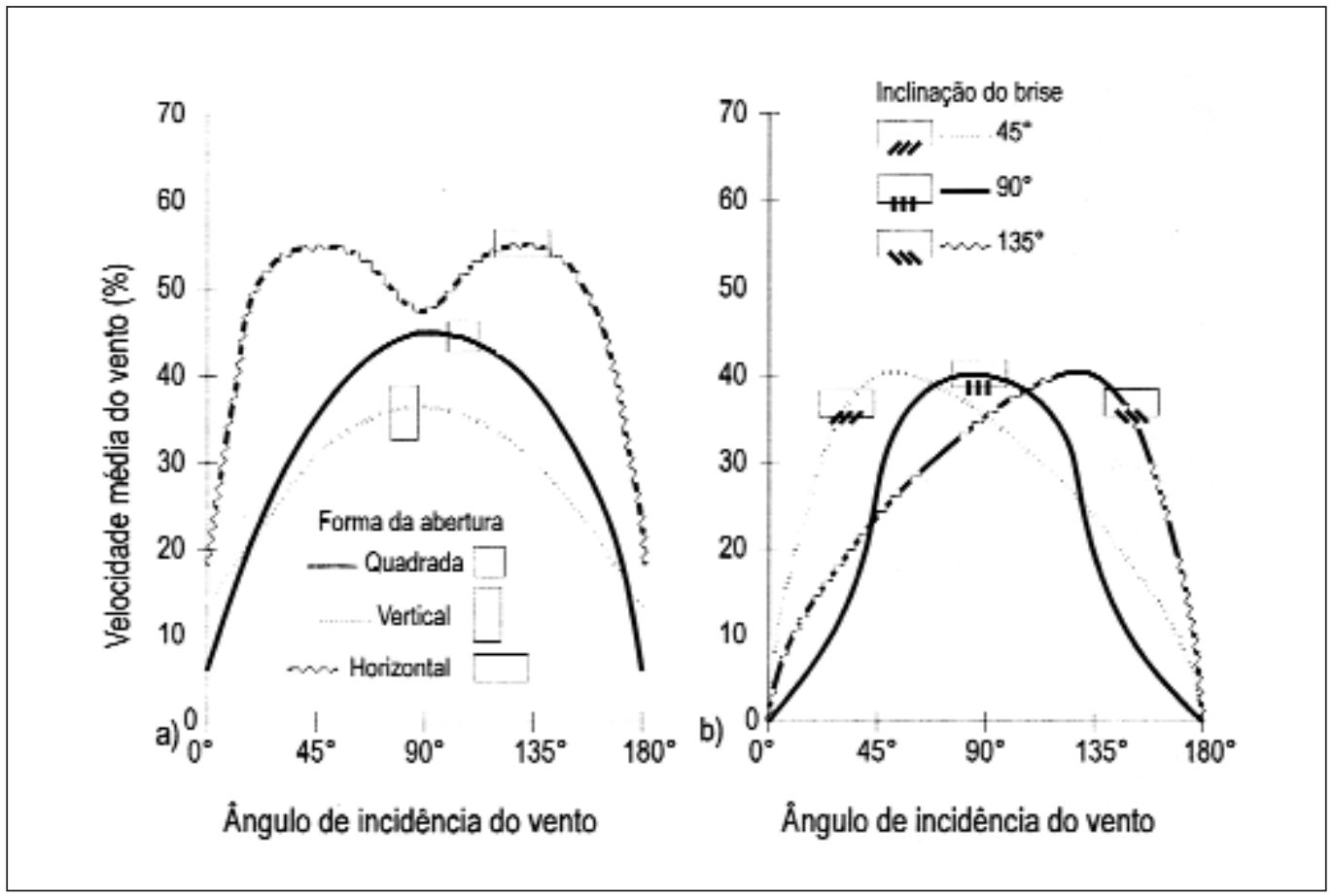

Ilustração 57: Efeito da forma da abertura em função da direção do vento e da existência de protetores solares verticais

Fonte: SOBIN, 1981, apud BITTENCOURT e CÂNDIDO, 2005.

tores solares verticais. Para cada ângulo de incidência do vento na fachada, alteram-se as velocidades médias do vento, assim como para cada forma de abertura. Para as aberturas retangulares, quando são avaliados os mesmos ângulos de incidência de vento nas mesmas aberturas e com o uso de "brise-soleil", nota-se que há uma perda de rendimento em função da direção e inclinação do painel do brise.

Entende-se, portanto que existe uma dimensão ótima para cada abertura com o maior ganho de luz natural e maior velocidade média do vento.

A IL.58 exemplifica, para uma cidade Brasileira, o quanto o potencial de luz em lux está disponível na face da janela, e o quanto este valor vai decaindo na medida em que se distancia da mesma. Além disto, pode-se ver que os limites das normas (NBR 5413) o sistema artificial apenas seria necessário a partir de 4 metros de distância da janela.

O projeto de iluminação para qualquer ambiente deve sempre considerar a integração da luz natural disponível com o projeto da iluminação artificial. $\mathrm{Na}$ IL. 59 apresenta um exemplo desta integração:

- No primeiro momento a luz natural atende até uma profundidade do ambiente (que depende da quantidade da luz disponível, e das características da 


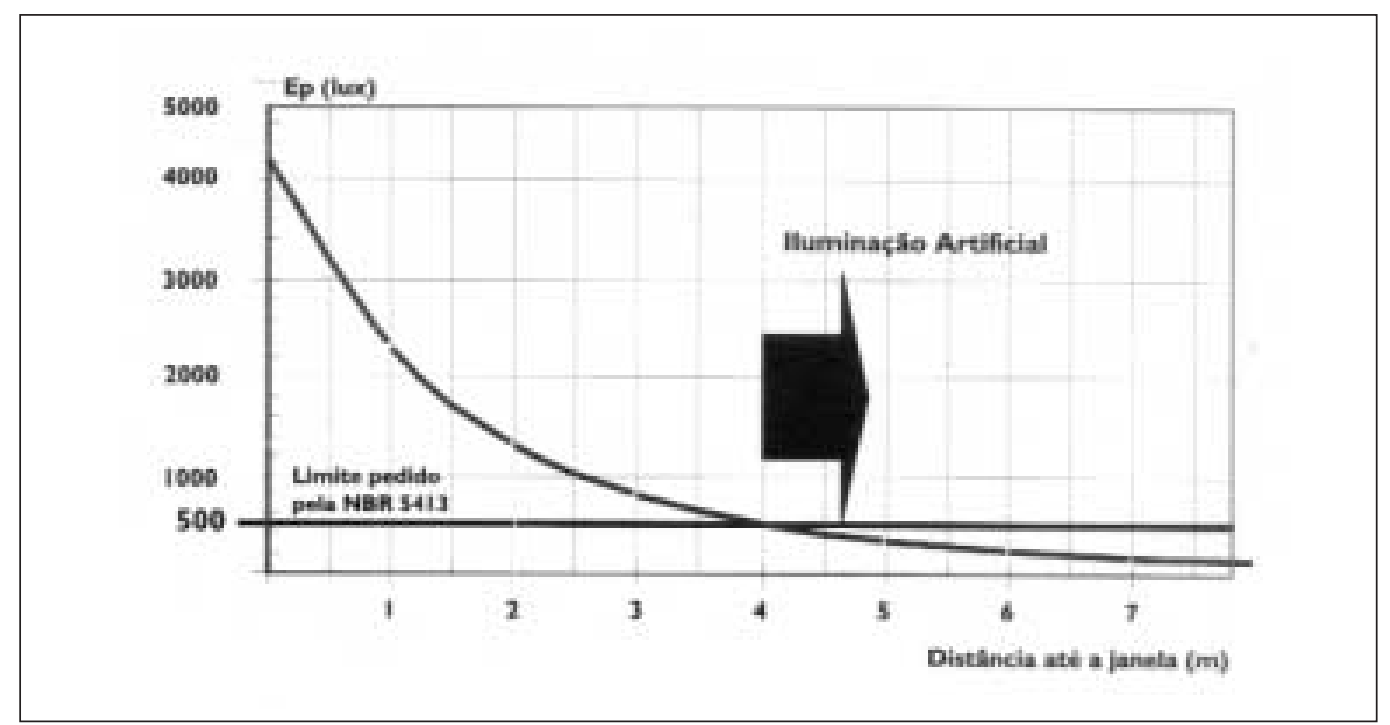

Ilustração 58: Distribuição da luz natural pela distância da janela, e a integração com o sistema artificial. Fonte: ALUCCI, 2006.

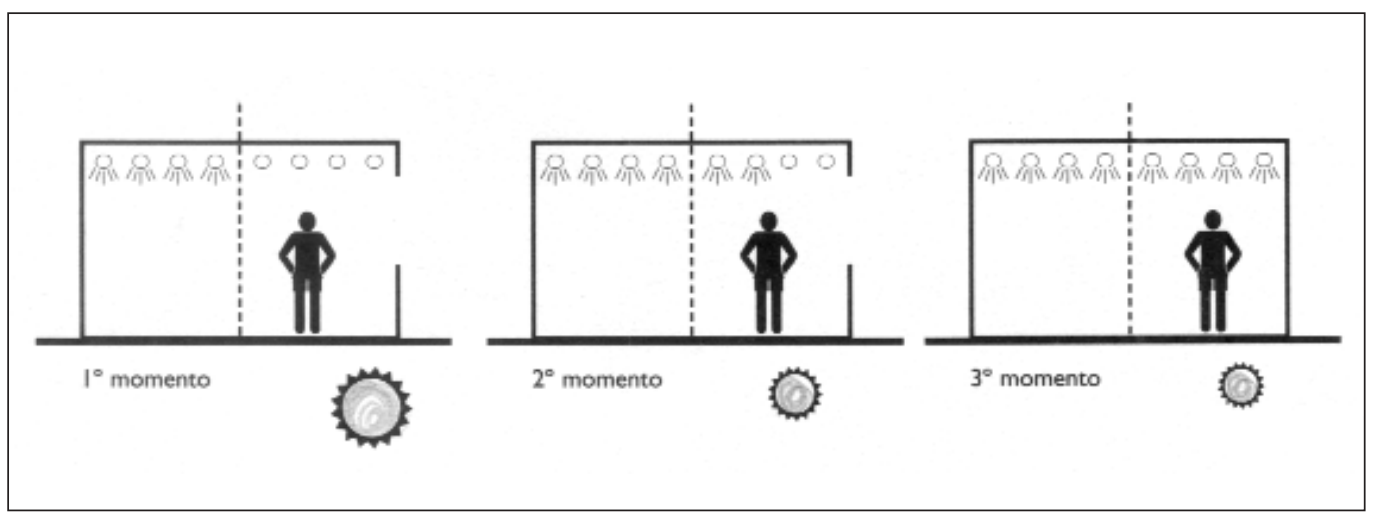

Ilustração 59: Melhor desempenho térmico e Luminoso: a integração da iluminação natural e artificial ao longo do dia

Fonte: ALUCCI, 2006.

abertura para que se possa a proveitar ao máximo a disponibilidade natural da luz e com isso melhorar o desempenho do edifício como um todo;

- No segundo momento, quando a disponibilidade da luz natural é menor, são acionadas novas lâmpadas mais distantes da janela;

- No terceiro momento, quando a luz natural não esta disponível em quantidade suficiente, todas as lâmpadas são acessas.

Os valores de iluminância, para cada atividade, são determinados pela Norma Brasileira de iluminação artificial (NBR 5413). Sendo assim, o melhor desempenho luminoso deve levar em consideração as exigências normativas e a disponibilidade de luz natural. 
No caso dos hotéis econômicos, ocupados a noite, das 20 ás 7 horas, este aproveitamento deixa de ser a prioridade no projeto, apesar de ser fundamental para a salubridade dos ambientes e normalmente estar relacionado com a ventilação natural. A higienização dos apartamentos depende da incidência de sol nas UH, já que ela é capaz de eliminar fungos e bactérias que se aproveitam de ambientes úmidos, escuros e sem ventilação adequada para se desenvolver.

\subsubsection{Exposição ao ruído}

O som propaga-se pelo ar, ou através dos materiais.

O desconforto acústico pode ser proveniente das chamadas fontes externas, tais como veículos, aviões, helicópteros e trens, e de fontes internas, que podem variar desde vozes, músicas, até a vibração de equipamentos.

Foram listados por BARING (1981) alguns cuidados acústicos básicos de edifício, dos quais cabe destacar os seguintes:

- Consulta aos planos de desenvolvimento urbano da região onde será construído o edifício;

- Verificação do zoneamento proposto;

- Levantamento de proteções naturais e de edificações do entorno que possam auxiliar na proteção do edifício às fontes de ruído locais;

- Implantação do edifício de forma a minimizar a sua exposição as fontes de ruido locais;

- Locação conveniente de "setores problemáticos" em termos acústicos e vibratórios, tais como garagens, casa de máquinas de elevadores, sistemas hidráulicos, centrais de ar-condicionado, etc;

- Locação conveniente em projeto dos espaços com "potenciais" para abrigar atividades ruidosas ( tais como cozinhas, áreas de lazer, etc.)

- Atenção para a proximidade ou a comunicação de ambientes acusticamente indesejáveis;

- Programação dos valores mínimos de isolação sonora a serem observados na execução de coberturas, fachadas, pisos e caixilhos em geral;

- Programação de todas as providências para a isolar as canalizações de águas, esgotos e dutos de ar condicionado, que são veículos de ruídos de vibrações;

- Especificação de revestimentos de pisos, providência complementar às decisões sobre as características de isolação aos ruídos de impacto que estes pisos devem apresentar;

- Especificação de revestimentos absorventes sonoros para corredores, 
saguões de entrada, salas de espera e outros locais em que possa ocorrer a reverberação prolongada ou "condução"de sons e ruídos;

- Detalhamento dos caixilhos observando o seu compromisso com a isolação sonora dos locais em que serão instalados;

No caso de hotéis, cuja principal atividade é o repouso, durante a noite, a melhor condição de isolamento acústico deve levar em conta também a interferência das UH vizinhas, quanto o ruído de pessoas e equipamentos deve ser tembém considerados.

Dependendo também do nível de ruído externo e das características construtivas internas, com maior ou menor isolamento acústico entre as $\mathrm{UH}$, muitos usuários relataram o uso de algum equipamento que gere ruído constante para que sejam simulados outros ruídos intermitentes, e mais elevados. Nas condições de repouso, estes são também ruídos indesejáveis, que podem prejudicar o sono. Refere-se aqui ao uso do próprio SAC como fonte sonora, mais um elemento que demonstra a importância na integração das soluções propostas em um projeto de arquitetura. 


\section{Análise paramétrica com base em estudo de caso}

A análise paramétrica busca avaliar o impacto de variáveis arquitetônicas, tanto nos componentes construtivos quanto na operação do edifício hoteleiro -, considerando como base inicial os dados empíricos do estudo de caso apresentado no Apêndice A.

Foram determinados, a partir de critérios estabelecidos, quais variáveis seriam alteradas nas simulações, levando-se em conta o impacto que elas teriam na arquitetura e no desempenho energético do edifício. A padronização da UH nos Hotéis Econômicos fez com que obtivéssemos os resultados da UH, sendo este o ambiente mais representativo dentro desta tipologia.

O comportamento térmico-dinâmico das UH considera a influência de um ambiente sobre o outro, em que foram consideradas as mesmas condições internas em todos eles. Foram analisados os dias representativos de verão e inverno, permitindo assim avaliar o potencial de estratégias de projeto específicas. Na avaliação anual do percentual de conforto, segundo a norma ASHRAE 55/2004, verificou-se o desempenho geral da edificação e do consumo do sistema de ar condicionado (SAC) na unidade habitacional $(\mathrm{UH})$, integrando as diferentes estratégias adotadas.

Com base nos resultados do cenário inicial, cujo modelo foi previamente calibrado com os dados empíricos levantados, foram feitas proposições de novas alternativas (cenários), na busca por avaliar o impacto das alterações no desempenho térmico e energético da edificação, avaliando também as condições de conforto dos usuários. 


\subsection{Metodologia}

O software utilizado nas simulações termo-dinânimcas foi o TAS, Thermal Analysis Simulation (TAS NG, 2005) ${ }^{21}$-. Este software leva em conta as condições climáticas, a geometria da edificação e suas características construtivas, calculando as variáveis ambientais de temperatura do ar, também denominada temperatura de bulbo seco (TBS), temperatura radiante média (TRM) e umidade relativa (UR) para todas ás 8760 horas do ano. A partir dos resultados são calculadas temperaturas efetivas (ET*) horárias, combinando TBS, TRM e UR em um único valor equivalente. Os resultados podem ser analisados hora a hora, ou em dias típicos de verão e inverno, verificando-se os períodos em que o ambiente analisado proporciona conforto aos ocupantes. Segundo o critério definido anteriormente, na seção 4.5, ficou estabelecido o uso dos limites considerados na norma ASHRAE 55 (2004).

A norma ASHRAE 55 (2004) estabelece a chamada temperatura efetiva de conforto, baseada nas médias mensais. As temperaturas efetivas de conforto, de acordo com este método, variam entre $23,0^{\circ} \mathrm{C}$ no inverno e $25,5^{\circ} \mathrm{C}$ no verão. Em um intervalo de $\pm 2,5^{\circ} \mathrm{C}, 90 \%$ das pessoas em um ambiente estão confortáveis e, em um intervalo de $\pm 3,5^{\circ} \mathrm{C}, 80 \%$ das pessoas. Acima desta tolerância, diz-se que o ambiente está quente e, abaixo, frio.

Devido às limitações do software no ajuste da Temperatura de Conforto (TC) para inverno e verão, foi determinada a abertura das janelas para um valor fixo no ano todo: $27,6^{\circ} \mathrm{C}$ e $20,6^{\circ} \mathrm{C}$ a temperatura máxima e a mínima, respectivamente. Sendo assim, os valores obtidos para os dias representativos de inverno e verão estão subestimados, em relação ao que se poderia obter com uma variação maior destes limites, ainda dentro dos valores aceitáveis pela norma ASHRAE 55 (2004).

Inicialmente, após a análise e diagnóstico do projeto de arquitetura, com base nos dados construtivos do estudo de caso (Apêndice $D$ ) foram definidas as características construtivas do modelo inicial utilizado nesta da pesquisa. A intenção foi aproximar ao máximo das características reais do edifício existente, para posteriormente serem feitas novas alternativas, buscando avaliar o impacto delas na arquitetura e no consumo de energia.

Esta avaliação ocorreu em diversas etapas que foram apresentadas na IL.5, e estão apresentadas detalhadamente a seguir, na IL. 60.

21. O software TAS foi validado pela International Energy Agency (IEA). 


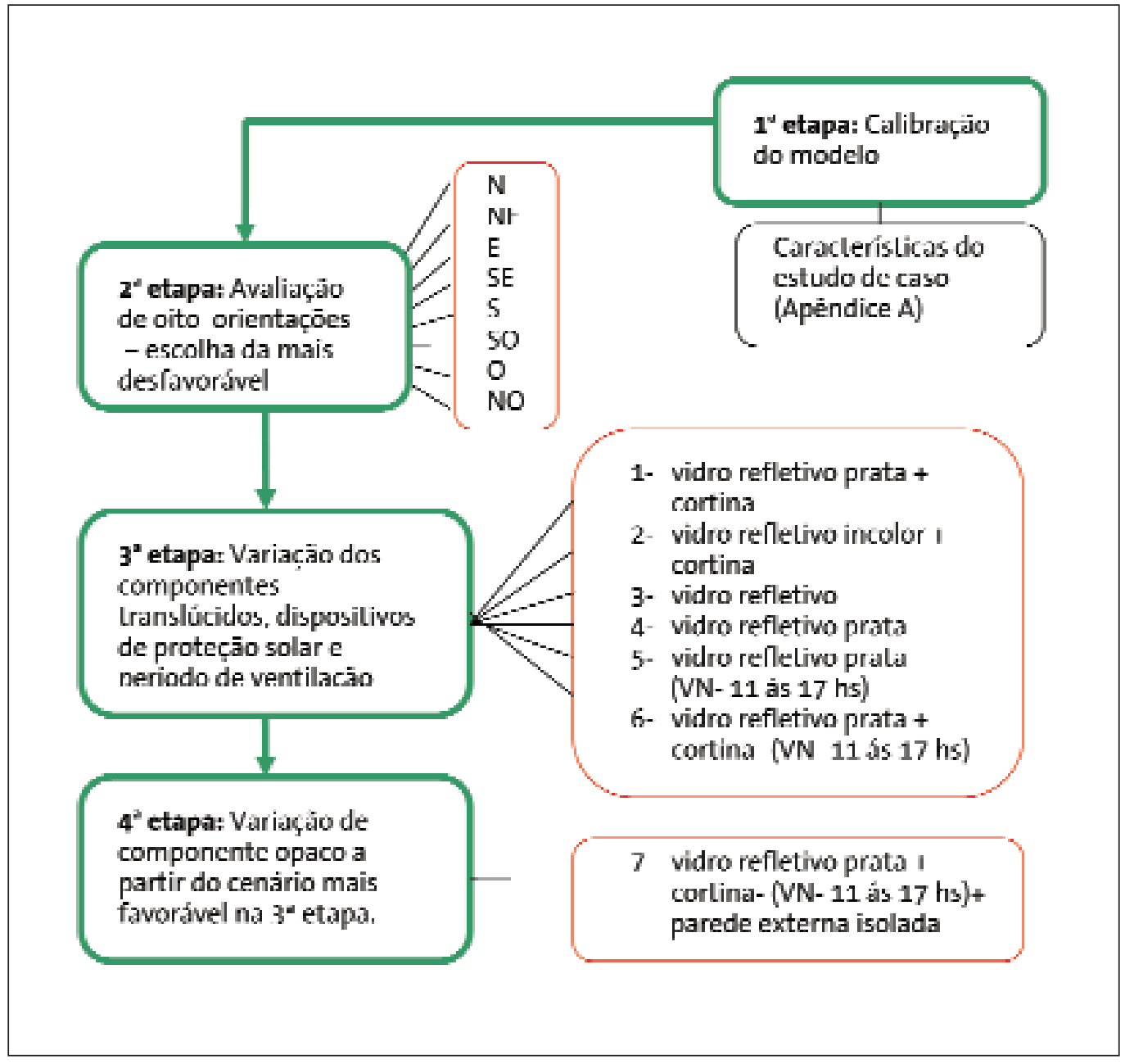

Ilustração 6o: Seqüência detalhada das variáveis simuladas.

$1^{\text {a }}$ etapa: Calibração do modelo base a ser simulado com os dados empíricos do estudo de caso (durante os 5 dias consecutivos de Janeiro de 2007). Foram considerados, nesta etapa, as janelas fechadas e o sistema de ar condicionado (SAC) desligado, assim como foram feitas as medidas apresentadas no Apêndice A.

$2^{\text {a }}$ etapa: Balanço anual das oito orientações para o modelo calibrado, considerando a porcentagem mensal de pessoas em conforto, insatisfeitas por frio ou por calor para a definição da orientação mais desfavorável a ser utilizada na etapa seguinte.

$3^{\text {a }}$ etapa: Variação dos componentes translúcidos, dispositivos e proteção solar e período de ventilação nos dias representativos de verão e inverno, para a definição da melhor alternativa entre elas, a ser utilizada na etapa seguinte.

$4^{a}$ etapa: Variação de componente opaco, para verificação da melhor combinação entre todos os anteriormente simulados. 


\subsection{Dados Climáticos}

O arquivo climático utilizado nas simulações foi proveniente do banco de dados anual desenvolvido por De Benedetto (2006) cujos dados foram provenientes do Laboratório MASTER do IAG ${ }^{22}$ USP de 2000 até 2005. Devido ao número de lacunas existentes nos arquivos de 2000, 2001 e 2002, a base considerou os dados para os anos de 2003 até 2005 . Apesar de não serem provenientes das médias de cinco anos, tratava-se de dados mais recentes, o que determinou a escolha desse arquivo climático. Com as mudanças climáticas e o aquecimento global, sabe-se que os dados climáticos provenientes de 20 anos atrás tendem a estar, ano a ano, cada vez menos compatíveis com a realidade atual.

Os dados da temperatura do ar de bulbo seco (TBS) e da umidade relativa do $\operatorname{ar}($ UR) anuais estão apresentados nas IL. 61 e 62.

Verifica-se, na linha de tendência plotada nas ILs. 61 e 62 que a maior faixa de desconforto para o arquivo climático analisado encontra-se no período mais frio do ano, quando a UR é menor, mais próxima do limite de UR de conforto (até 65\%).

Devido à grande quantidade de dados, os valores foram analisados no mês de referência de verão e inverno, que foram os de maior e menor média de temperatura (Fevereiro e Agosto, respectivamente). Os dados plotados de TBS dos meses encontram-se nas ILs. 63 e 64, comparados com os limites máximos e mínimos da Temperatura de Contorto (TC) determinada como referência nas simulações.

Comparando as duas ilustrações, verifica-se que as temperaturas do mês de verão estão mais próximas da faixa da temperatura de conforto (TC) do que as temperaturas do mês mais frio. Pode-se prever, portanto, que o consumo anual devido à carga sensivel do sistema de ar condicionado (SAC) deverá ser proporcionalmente maior para aquecimento do que para o resfriamento, segundo a base de dados climáticos utilizada.

\subsubsection{Tratamento dos dados Climátics para a 1a etapa}

Na etapa da calibração do modelo, foi utilizada a base de dados anuais, descrita anteriormente, porém, no período em que foram feitas as medições (Apêndice A), foram tratados os dados reais do ano de 2007, a partir da base de dados da estação meteorológica da IAG USP situada no Parque do Estado.

22. IAG: Instituo de Astronomia, Geofísica e Ciências Atmosféricas. 


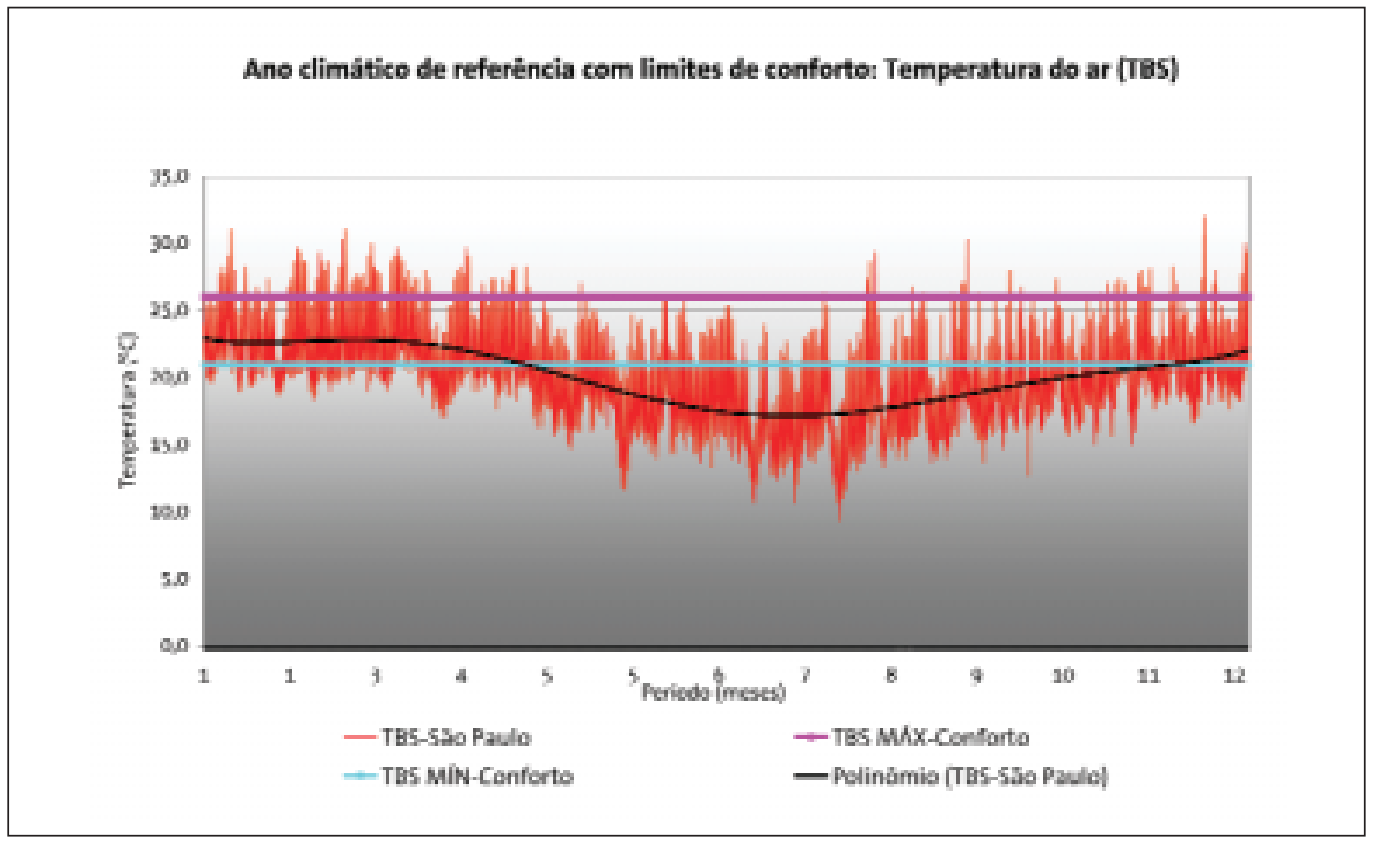

Ilustração 61: Ano climático de referência para São Paulo com indicação dos limites de conforto: Temperatura do ar (TBS).

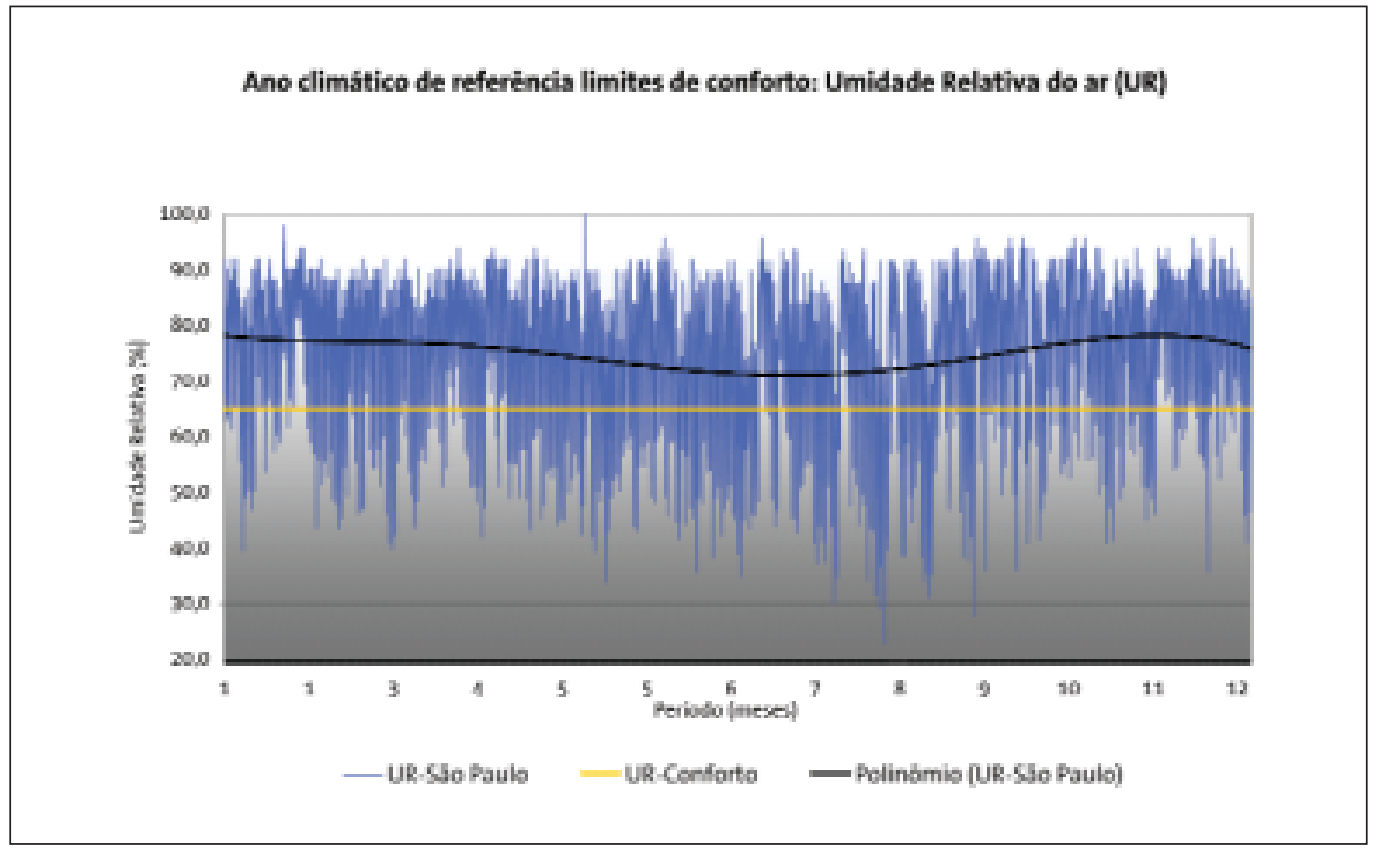

Ilustração 62: Ano climático de referência para São Paulo com indicação dos limites de conforto: Umidade Relativa do ar (UR). 


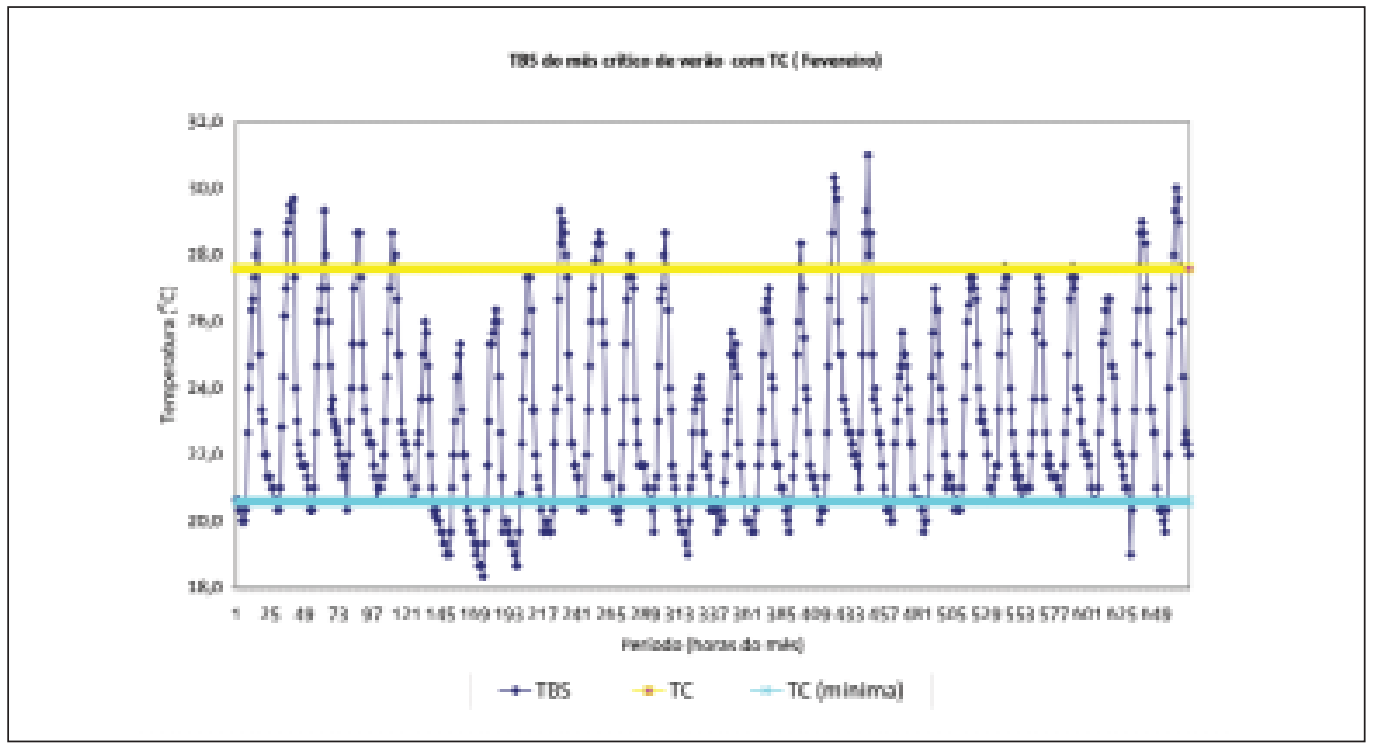

Ilustração 63: TBS do mês mais crítico de verão com TC (Fevereiro).

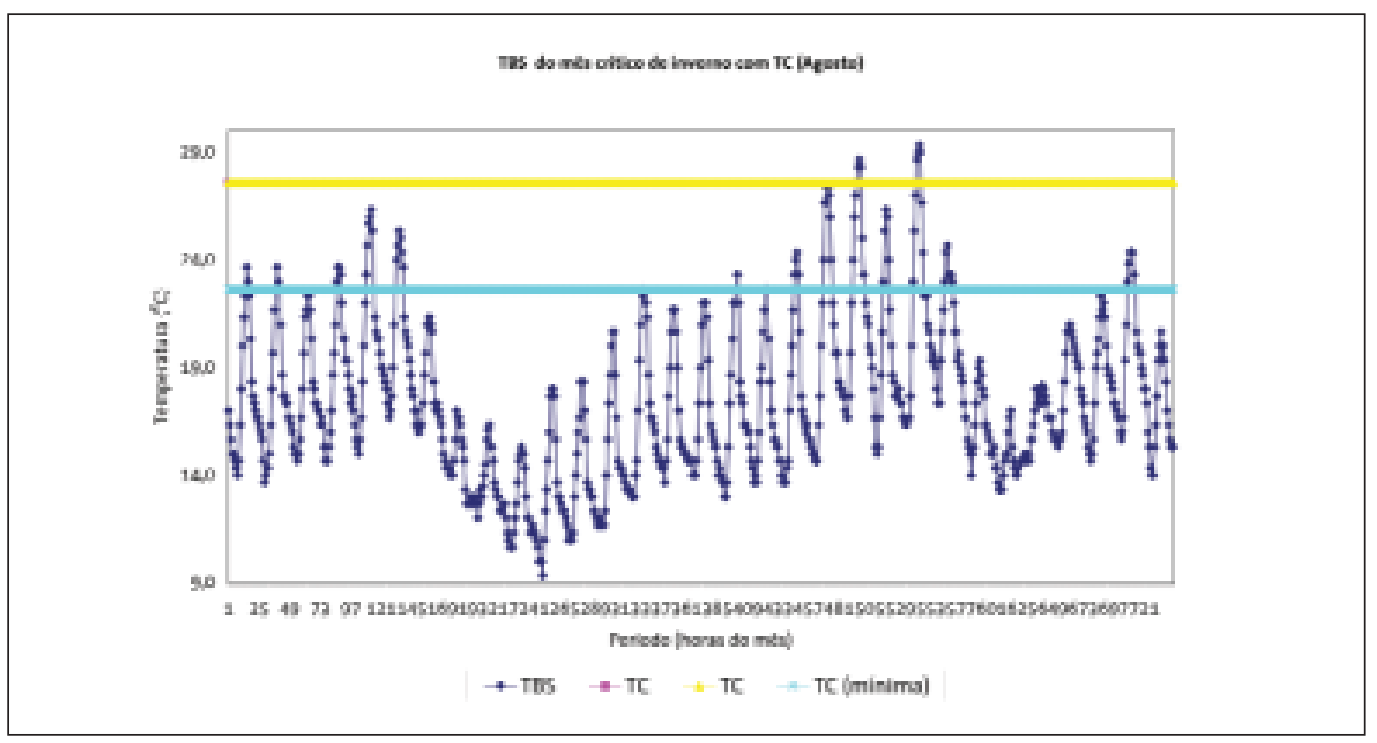

Ilustração 64: TBS do mês crítico de inverno com TC (Agosto).

A proximidade dessa estação com o objeto de estudo está indicada na seção 2.2 do Apêndice A.

Tais dados, os dos mesmos cinco dias em que ocorreram as medições, foram tratados de modo a substituir os mesmos dias no arquivo climático de De Benedetto (2006). Foram fornecidos os valores de:

- Temperatura de bulbo seco $\left({ }^{\circ} \mathrm{C}\right)$;

- Velocidade do ar (m/s);

- Umidade relativa do ar (\%);

- Insolação; 
- Radiação global (MJ/m²);

- Nebulosidade.

O tratamento destes dados para inclusão no arquivo climático do software consta no Apêndice A.

\subsubsection{Tratamento de dados para a escolha dos dias representativos de inverno e verão}

Devido à dificuldade de leitura dos 8760 dados horários do ano, para facilitar a interpretação dos resultados obtidos nas simulações paramétricas, optou-se por calcular um dia representativo de inverno e um de verão. Esse cálculo baseouse no cálculo do dia típico, que foi descrito por Siqueira, et. al (2005) a partir do método desenvolvido por Akutso e Vittorino (1998).

Com base na análise dos dados mensais, nas ILs. 63 e 64 respectivamente, foram feitos cálculos para a definição do dia representativo de projeto para as duas estações. Apesar da seqüência de cálculo basear-se na seqüência do dia típico de Akutso e Vittorino (1998), não se pode falar em dia típico, pois a base do arquivo climático utilizado não é de 10 anos, ponto de partida na definição do dia típico de projeto.

Dessa forma, com a base de arquivo anual, foram definidos o mês mais quente e o mês mais frio do ano (Fevereiro e Agosto, respectivamente). Em cada um deles, verificou-se a freqüência de ocorrência de temperatura, conforme apresentado nas ILs. 65 e 66.

Para cada um dos meses, calculou-se a média horária de temperatura, resultando na temperatura média hora-a-hora para os dois meses (inverno e verão). Por fim, para cada um deles, verificou-se qual dia real do mesmo mês do banco climático teria o menor desvio padrão em relação ao dia médio. O resultado dessa análise, indicado nas ILs. 67 e 68 (verão e inverno, respectivamente), apresentam os dias representativos em cada situação.

Pode-se notar que durante o dia, que no dia representativo de inverno, o desvio padrão é bem maior comparado ao do verão. Porém, durante a noite os valores são bem próximos nos dois casos.

Com isso, serão utilizados os dias representativos, 20 de fevereiro - verão e 27 de agosto - inverno, nas análises dos resultados da avaliação paramétrica. 


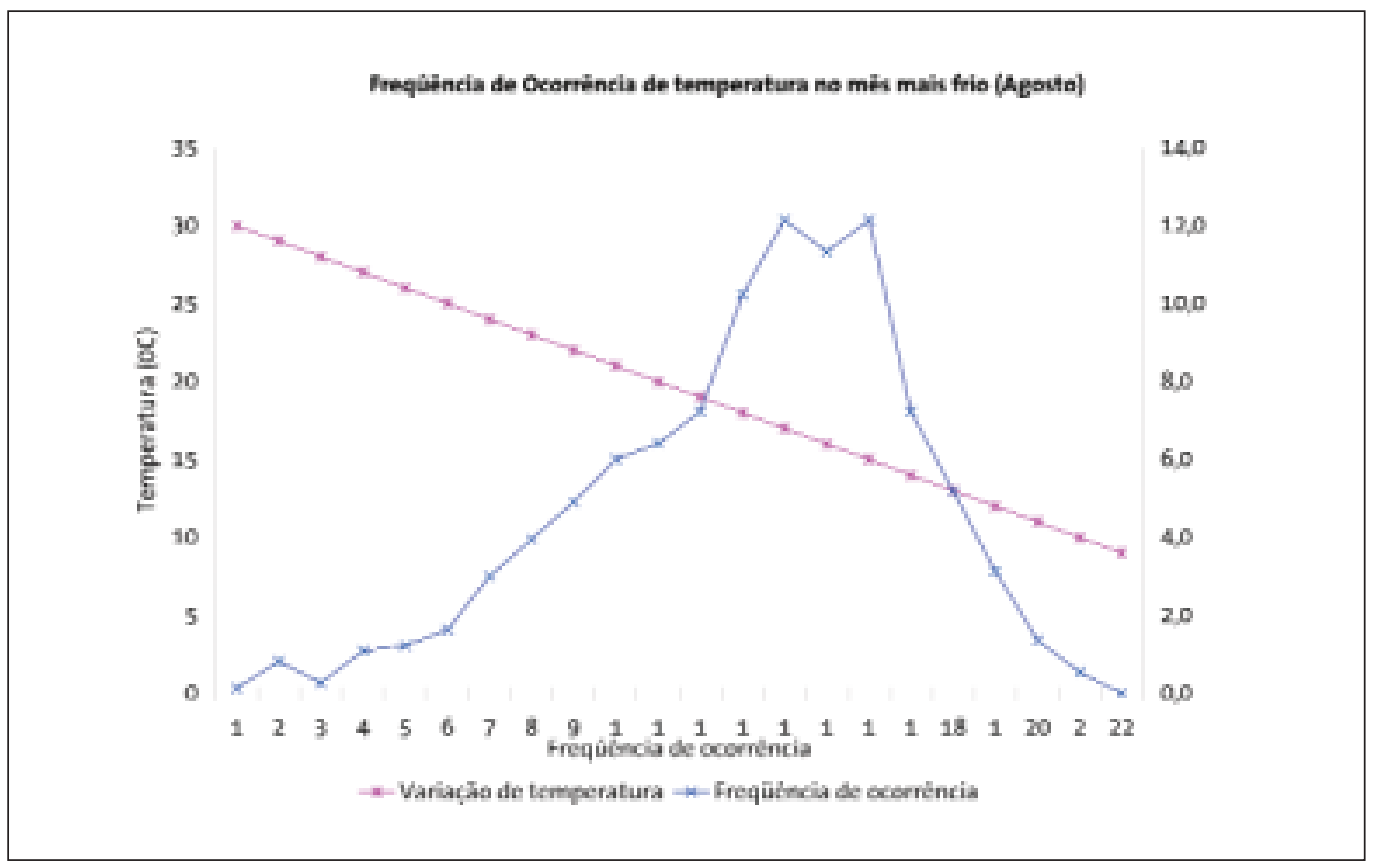

Ilustração 65: Freqüência de ocorrência de temperatura no mês de Agosto

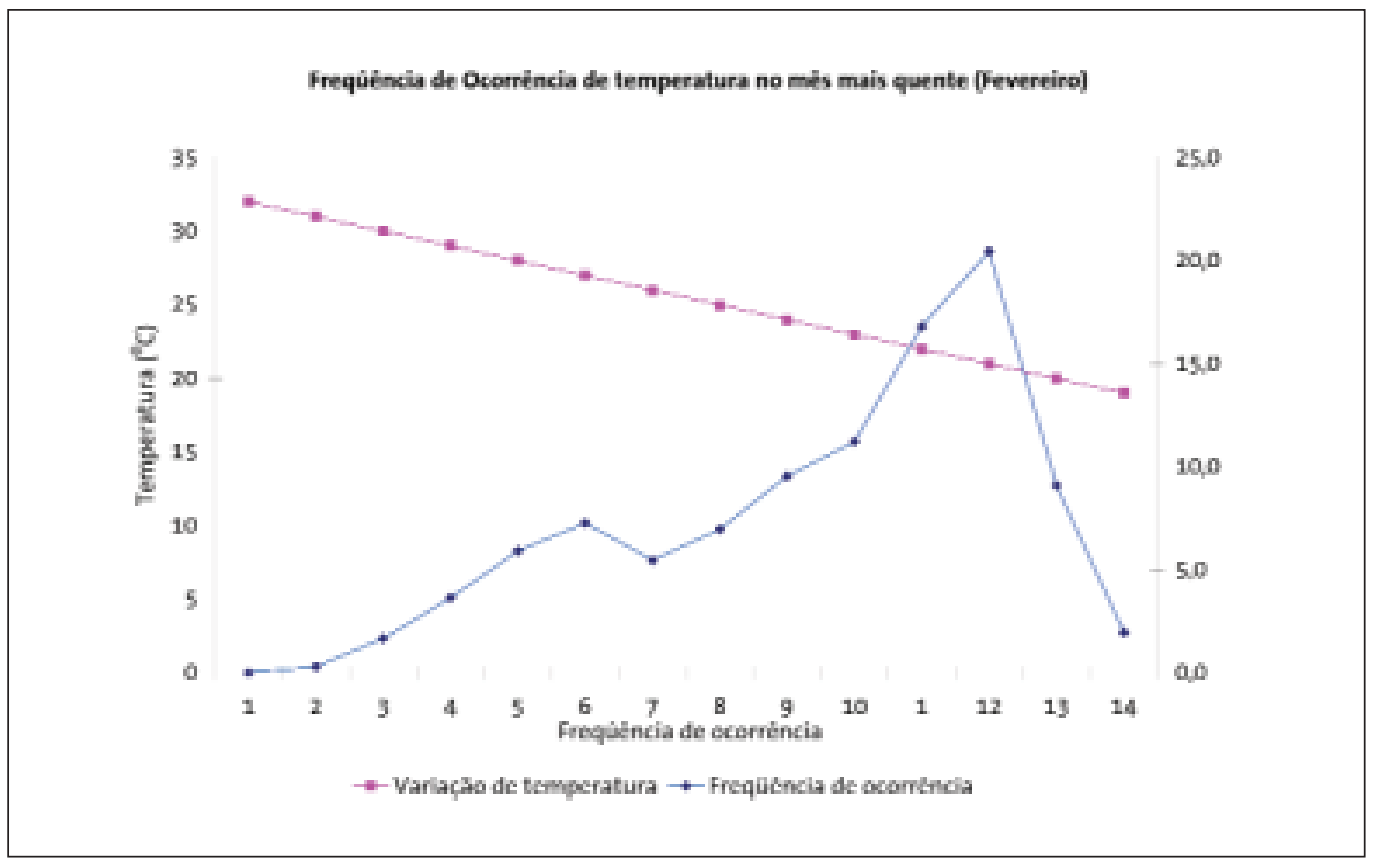

Ilustração 66: Freqüência de ocorrência de temperatura no mês de Fevereiro 


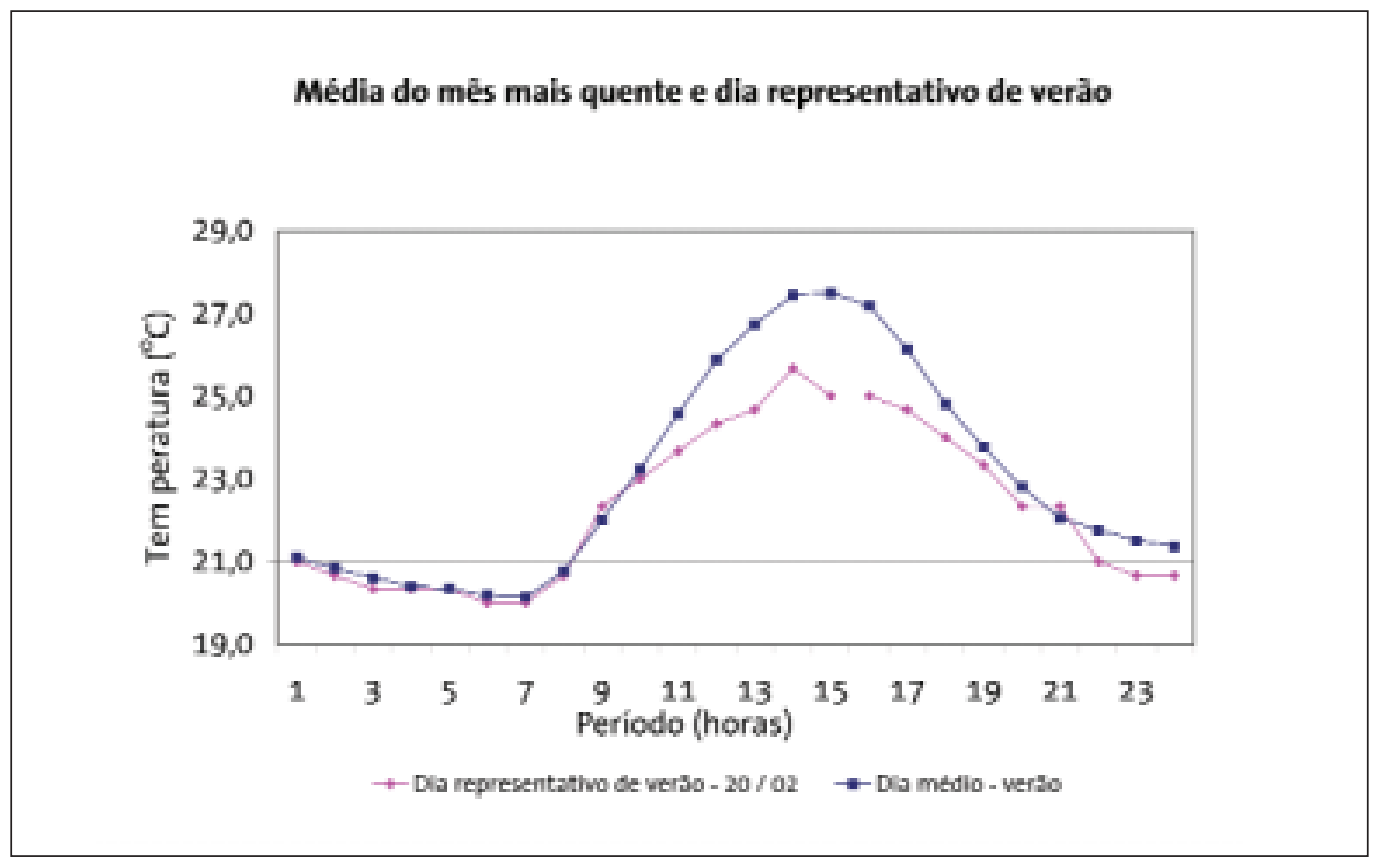

Ilustração 67: Dia médio do mês mais quente (verão) e dia representativo de verão - dia 51 do arquivo climático utilizado

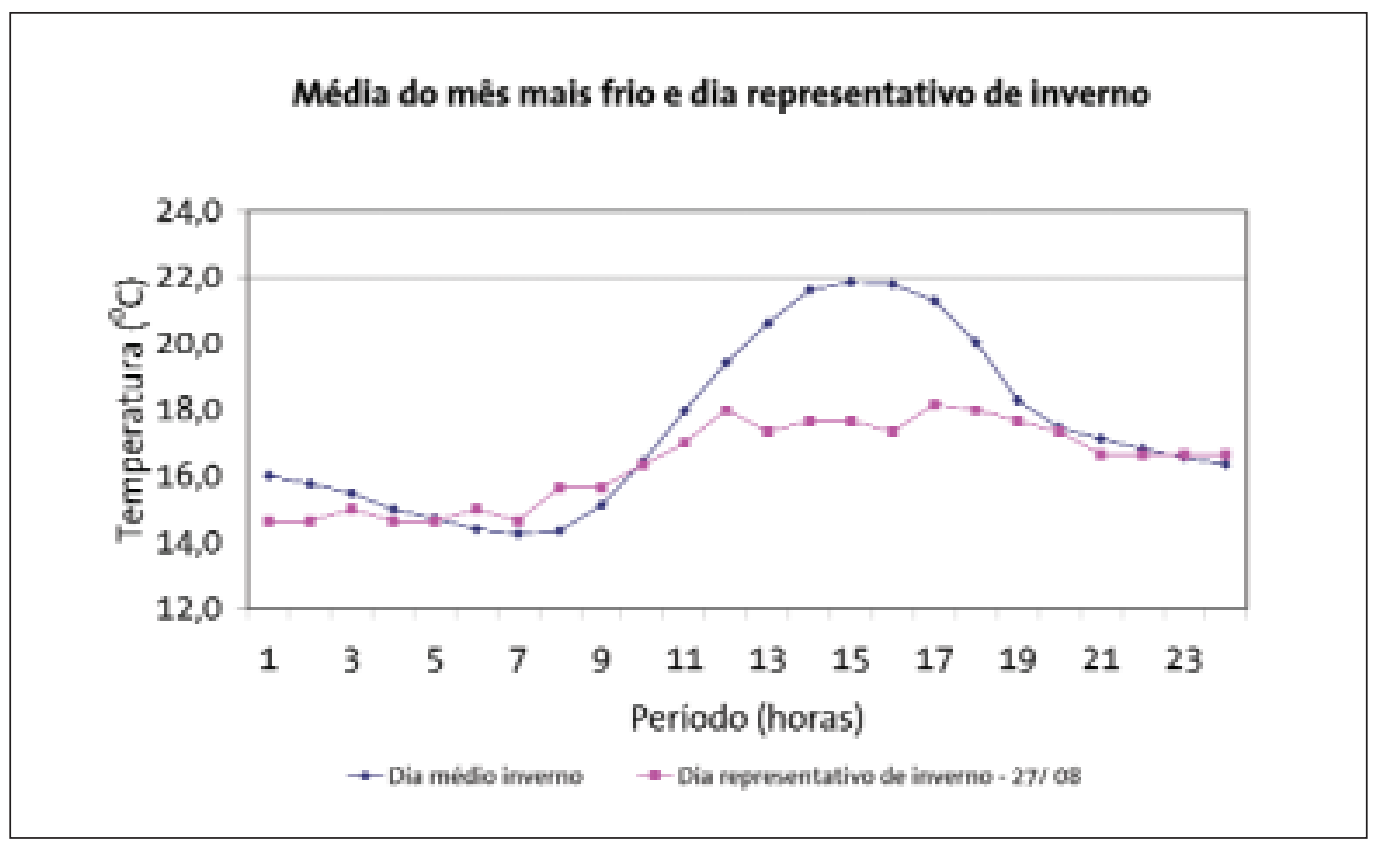

Ilustração 68: Dia médio do mês mais frio (inverno) e dia representativo de inverno - dia 239 do arquivo climático utilizado 


\subsection{Critério de avaliação}

Na avaliação de conforto térmico, foi definido tanto modo de condicionamento do ambiente quanto o índice de conforto utilizado. As definições feitas nessas duas etapas estão apresentadas a seguir.

\subsection{1 Índice de conforto térmico}

Conforme apresentado na seção 4.5, o índice de conforto térmico adotado na avaliação de conforto foi o modelo adaptativo da ASHRAE 55 (2004). Apesar das limitações do modelo para as condições de ocupação avaliadas, no caso Hotel Econômico, o modelo adaptativo foi o escolhido por ser considerado o mais adequado ao objeto de estudo desta pesquisa.

Para São Paulo, considerando o arquivo climático utilizado, as faixas de temperatura do modelo adaptativo, para inverno e verão, consideram $90 \%$ e $80 \%$ de satisfeitos, e os valores médios estão apresentados na TAB. 10.

Devido às limitações do modelo do software na parametrização dos dados foram considerados valores fixos de TC máxima e mínima para o ano todo, diferentemente do que ocorre com o modo misto, em que a TC oscila ao longo do ano, todo de acordo com a variação da temperatura do ar externa.

Sendo assim, no dimensionamento da faixa limite de temperatura a ser considerada pelo software, foram considerados os valores médios para os $90 \%$ de satisfeitos, o que resulta nas temperaturas fixas de $27,6{ }^{\circ} \mathrm{C}$ (TC máxima) e $21,6{ }^{\circ} \mathrm{C}$ (TC mínima). Estes valores são os mesmos que estão indicados nas ILs. 61 e 62 , no arquivo climático anual.

Com isso, sabe-se que os valores obtidos nos resultados simulados serão subestimados, podendo ser, numa etapa futura, readequados com valores variáveis para cada estação do ano ou, numa melhor hipótese, para os valores mensais do ano todo.

\subsubsection{Opção de condicionamento para as simulações}

Como foi descrito na metodologia de projeto proposta da pesquisa, na seção 4 do presente trabalho, a partir da avaliação dos dados climáticos e das características da ocupação, foram feitas as opções de condicionamento em um dado projeto. Devido às particularidades da tipologia avaliada, optou-se por um condicionamento misto: manter o sistema de ar condicionado como opção de 
TABELA 10: LIMITES DE TEMPERATURA DE CONFORTO SEGUNDO

O MODELO ADAPTATIVO DA ASHRAE 55 (2004)

\begin{tabular}{|llll|}
\hline Limites & Inverno & Verão & Média \\
\hline T máxima $-90 \%$ & 26,7 & 28,5 & $\mathbf{2 7 , 6}$ \\
\hline T máxima $-80 \%$ & 25,7 & 27,5 & 26,6 \\
\hline TC & 23,2 & 25 & 24,1 \\
\hline T mínima - 90\% & 20,7 & 22,5 & 21,6 \\
\hline T mínima - 80\% & 19,7 & 21,5 & $\mathbf{2 0 , 6}$ \\
\hline
\end{tabular}

condicionamento, porém com o máximo aproveitamento das condições naturais para o melhor desempenho energético do edifício como um todo.

Os parâmetros utilizados nas simulações foram:

- As janelas abrem quando $27,6^{\circ} \mathrm{C}\langle\mathrm{TBS}\rangle 21,6{ }^{\circ} \mathrm{C}$, e quando a UR ultrapassar o valor de $65 \%$;

- Quando TBS $<21,6^{\circ} \mathrm{C}$, as janelas são fechadas gradualmente, e o sistema de aquecimento é acionado;

- Quando TBS $>27,6^{\circ} \mathrm{C}$, as janelas são fechadas gradualmente e o sistema de resfriamento é acionado.

Dessa forma, prevê-se o melhor desempenho energético do edifício como um todo, já que o consumo de energia do SAC é bastante representativo na tipologia de arquitetura dos Hotéis Econômicos, como foi apresentado na IL. 3, p. 7 .

\subsection{Calibração do modelo - $1^{\text {a }}$ etapa}

A calibração do modelo foi feita com base nos valores de TBS e TRM medidos, cujo trabalho está descrito no Apêndice A, e com os valores obtidos do modelo paramétrico no TAS.

O tratamento do arquivo climático está descrito na seção 5.2 do Apêndice A - Levantamento dos dados empíricos: medições em estudo de caso.

Foram consideradas, no modelo paramétrico, todas as características do 
modelo real, obtidas através de consulta a memoriais técnicos e aferidos nas visitas ao local.

Por se tratar de um modelo, ou seja, uma representação da realidade, considera-se que os valores simulados sofrerão alguma alteração em relação aos valores reais medidos, o que justifica ainda mais o uso dos valores medidos como base de parâmetros para calibrar o modelo paramétrico.

Algumas variáveis como adequação ao período determinado para cada uma das condições internas (schedules) foram pré-dimensionadas. A interferência delas no resultado final foi verificada nos resultados obtidos no valor de TBS no interior das zonas de referência ${ }^{23}$ (face NO e SE).

No modelo simulado, foram atribuídas zonas térmicas ${ }^{24}$ a três quartos de cada lado em um mesmo andar e dispostos frente-a-frente. O valor obtido nas medições das UH, de cada zona, foi o dado considerado como referência nesta etapa.

O modo de funcionamento das aberturas foi definido de acordo com o observado na etapa do levantamento de dados empíricos (Apêndice A), lembrando-se que este levantamento foi realizado com as janelas fechadas, com UH ocupada pelos "hóspedes de controle" ${ }^{25}$. As taxas de infiltração e ventilação foram ajustadas na própria calibração do modelo, conforme os resultados obtidos nas ILs.69 e 70.

Na IL. 69, verifica-se que as temperaturas externas ao longo dos três dias foram aumentando gradativamente e ainda não estavam estáveis, como se recomenda para a escolha da condição ideal a ser analisada.

Devido às limitações de disponibilidade de ambientes em realizar as medidas em um número maior de dias, foram utilizados esses valores sendo definido qual dos três dias seria o mais adequado para ser utilizado na etapa da calibração do modelo. Essa escolha foi para o dia, cujos resultados de TBS e TRM medidos e simulados estão apresentados nas 70 e 71, respectivamente.

Verifica-se na IL. 70 a variação dos dados empíricos da TBS nos pontos centrais do ambiente das duas faces (NE e SO) e na bancada (BANC), como foi indicado o posicionamento dos sensores na seção 2.3 do Apêndice $A$.

23. Fala-se aqui sobre um ambiente simulado, que seriam as UH em que foram feitas as medidas.

24. Entende-se como zonas térmicas, segundo o processo do TAS, como zonas em que foram determinadas as condições de ocupação na parametrização dos dados, e que o programa calcula as trocas térmicas apenas dos ambientes zoneados, considerando a interação entre estes ambientes.

25. Foram as duplas de ocupantes (uma para cada quarto) que ocuparam as UH durante o período em que ocorreram as medidas, seguindo as recomendações de uso e período de acionamento dos equipamentos de acordo com o estabelecido para a pesquisa (Apêndice C). 


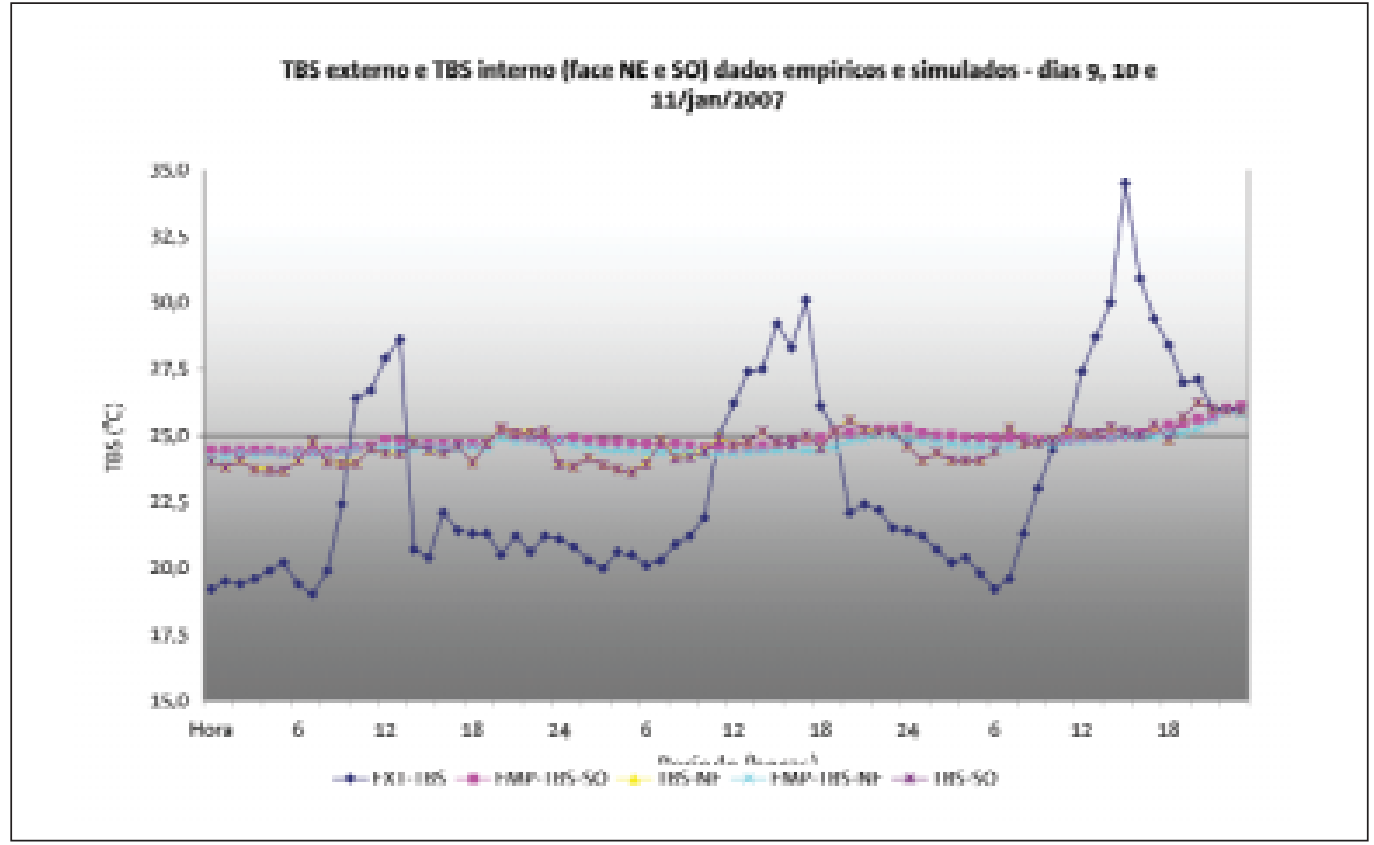

Ilustração 69: TBS externo de TBS interno (face E e O) - dados empíricos (EMP) e simulados

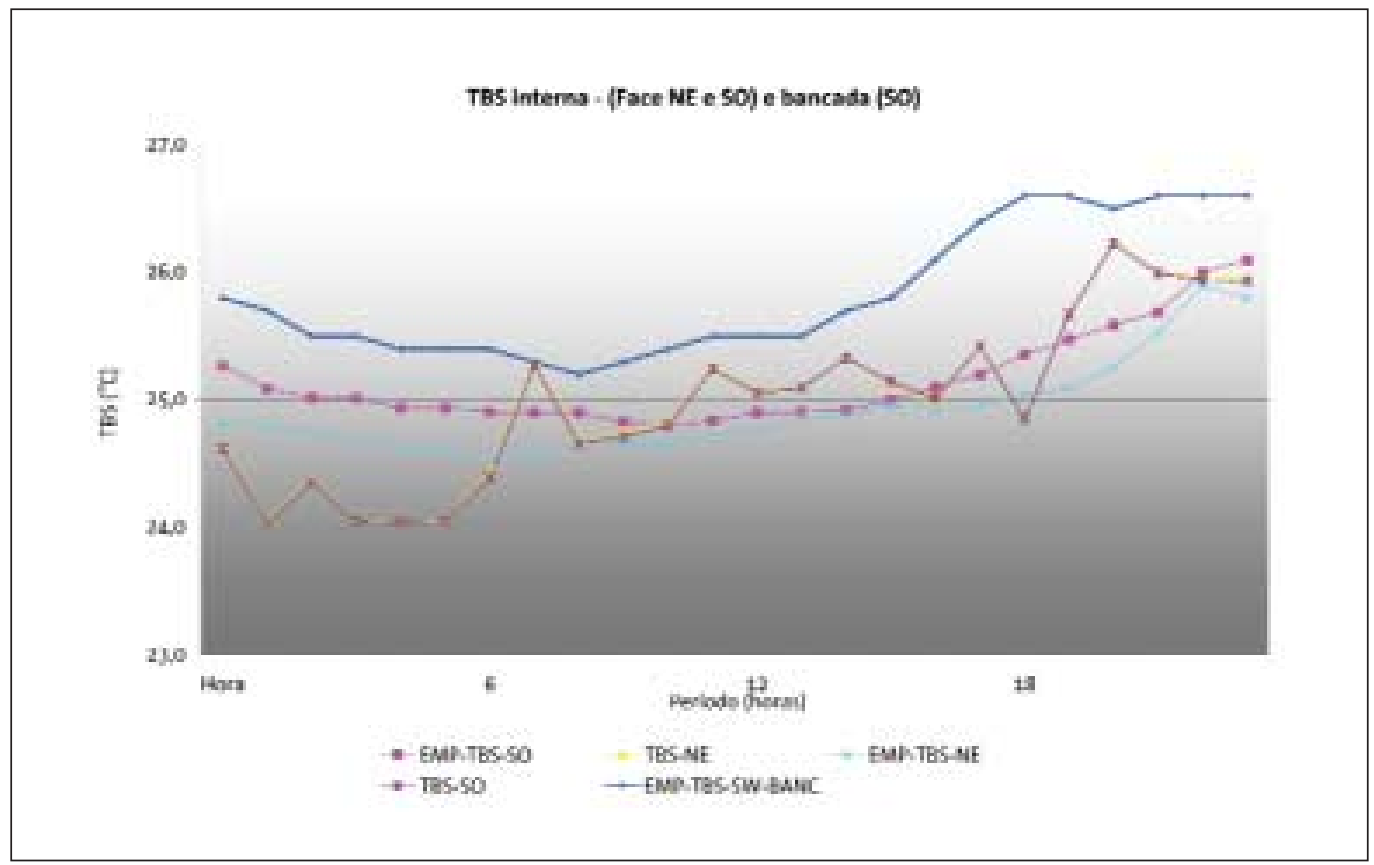

Ilustração 70: TBS externo de TBS interno (face NE e SO) - dados empíricos (EMP) e simulados em 24 horas (1 dia). 


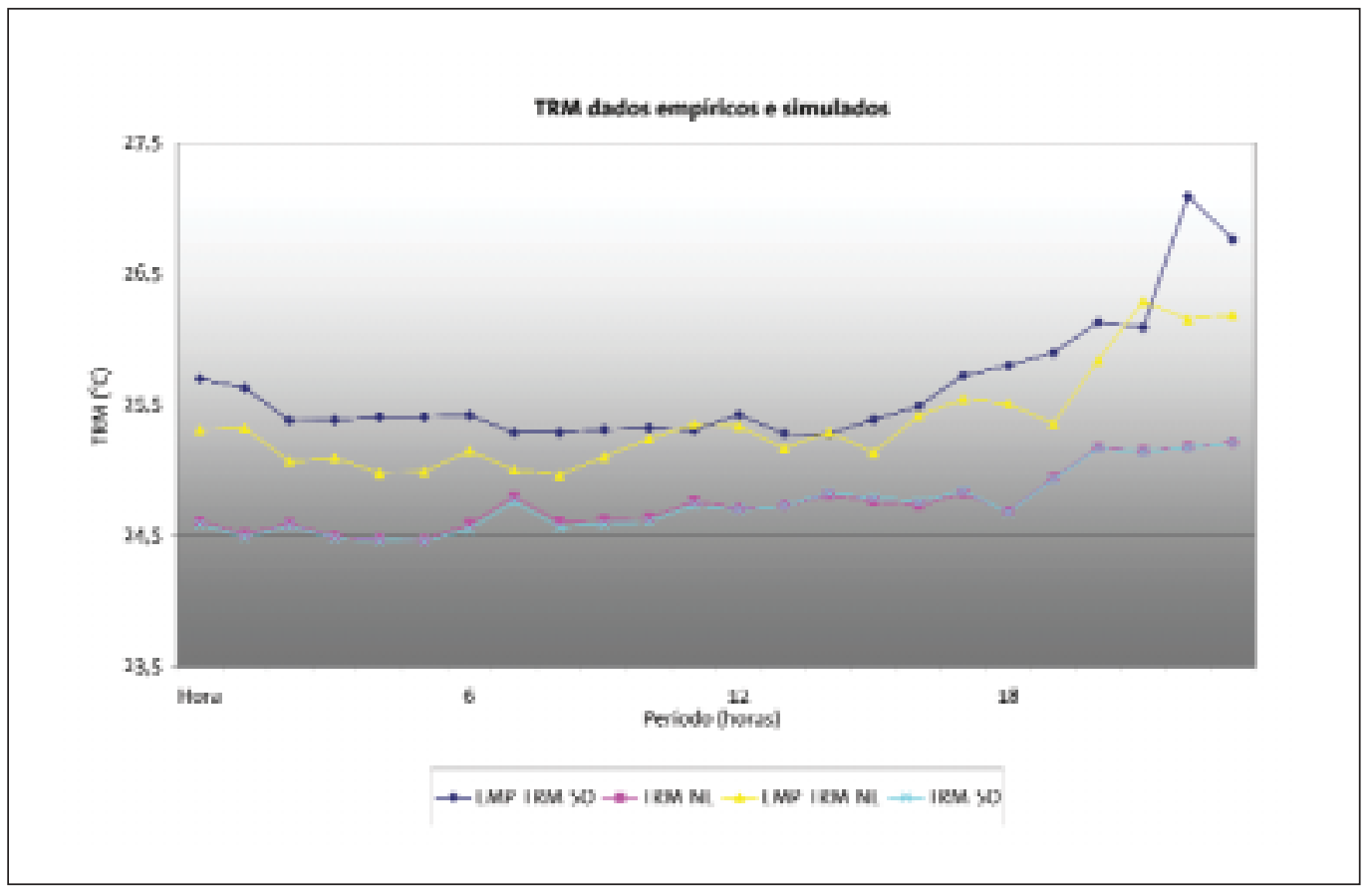

Ilustração 71: TRM dados empíricos e simulados.

A TBS medida (EMP -TBS) está mais próxima dos valores simulados em ambas as orientações no período diurno, com variações de temperatura menores do que meio grau Celsius. As maiores diferenças ocorreram no período noturno, na face Oeste, às 3 horas, com uma variação de 1 grau Celsius, e na face Nordeste ás 20 horas, com uma variação de 0,9 grau Celsius.

Quando comparados os valores obtidos de TRM da simulação com os valores calculados com base nos dados medidos de temperatura de globo (cujo método de cálculo está descrito na seção 5.4 do Apêndice A), obtivemos os dados apresentado na IL. 71.

Pode-se verificar que as variações do modelo com os dados empíricos não ultrapassam em um grau Celsius em ambas as faces, com exceção das 22 horas, em que se verificou um aumento abrupto de até dois graus Celsius. Isso ocorreu devido à alteração da carga interna, já que se trata do mesmo período ocupado durante o experimento.

Com isso, o resultado do modelo paramétrico pode ser utilizado como modelo base nas etapas seguintes.

Partindo do modelo já calibrado, o modelo-base foi analisado segundo o método descrito anteriormente, cujas etapas posteriores estão apresentadas a seguir. 


\subsubsection{Balanço anual de oito orientações - $2^{\mathrm{a}}$ etapa}

Considerando as mesmas condições internas de ocupação e as características do modelo base, foram variadas as orientações do modelo para verificar qual delas seria a mais desfavorável, considerando como base a avaliação da condição de conforto dos usuários ao longo do ano todo.

Nessa etapa, ainda foram mantidas as janelas fechadas, assim como foram feitas as medições, para que na etapa seguinte fossem realizadas as alterações nas condições de operação.

Os resultados horários de temperatura radiante média (TRM), temperatura do $\operatorname{ar}$ (TBS) e umidade relativa do ar (UR) da zona de referência foram utilizados no cálculo da temperatura efetiva interna (TE*) e comparados com a temperatura de conforto (TC), calculada a partir do modelo adaptativo.

O resultado dessa avaliação foi uma análise mensal da porcentagem de tempo em que a zona avaliada encontra-se na faixa de conforto ou desconforto (por frio ou calor). Foi considerado, para esta etapa da pesquisa, o limite de 9o\% de pessoas satisfeitas, conforme recomenda a norma ISO7730 (1994).

Nas TABs. 11 até 18 estão apresentados os resultados para as oito orientações avaliadas. Em vermelho estão destacados os meses com a maioria em desconforto (acima de 50\%) tanto por calor, e em vermelho, quanto por frio, em verde.

Os valores apresentados apontaram para a orientação Oeste como a pior de todas, aquela que possui maior percentual de desconforto ao longo do ano. Destaque-se que foi avaliada a combinação das duas orientações mais desfavoráveis (já que a tipologia da arquitetura é predominantemente retangular, resultando em UH com duas orientações opostas).

No balanço anual também foram obtidos os valores horários mensais durante o período de ocupação determinado. No exemplo da IL. 72, para o mês de fevereiro está indicado conforto (C), quente (Q), ou frio (F), em cada uma das horas ocupadas do dia do mês, se os usuários estão em conforto ou desconforto segundo os critérios adotados.

Como foram consideradas, nesta etapa, as janelas fechadas, na etapa seguinte, após a definição da pior orientação, foi alterado o modelo-base possibilitando a abertura da janela e o acionamento do sistema ativo de condicionamento artificial, seguindo os limites pré-estabelecidos do modelo adaptativo. 


\begin{tabular}{|lccc|}
\hline $\begin{array}{l}\text { TABELA 11: PORCENTAGEM DE HORAS MENSAIS EM CONFORTO } \\
\text { NA FACE NORTE (10 \% DE INSATISFEITOS) }\end{array}$ \\
\hline Mês & Frio & Conforto & Quente \\
\hline Janeiro & $0,0 \%$ & $58,1 \%$ & $41,9 \%$ \\
\hline Fevereiro & $0,0 \%$ & $51,2 \%$ & $48,8 \%$ \\
\hline Março & $0,0 \%$ & $54,8 \%$ & $45,2 \%$ \\
\hline Abril & $0,0 \%$ & $54,8 \%$ & $45,2 \%$ \\
\hline Maio & $0,0 \%$ & $93,3 \%$ & $6,7 \%$ \\
\hline Junho & $0,0 \%$ & $100,0 \%$ & $0,0 \%$ \\
\hline Julho & $0,0 \%$ & $100,0 \%$ & $0,0 \%$ \\
\hline Agosto & $47,6 \%$ & $52,4 \%$ & $0,0 \%$ \\
\hline Setembro & $0,0 \%$ & $100,0 \%$ & $0,0 \%$ \\
\hline Outubro & $0,0 \%$ & $100,0 \%$ & $0,0 \%$ \\
\hline Novembro & $0,0 \%$ & $99,7 \%$ & $0,3 \%$ \\
\hline Dezembro & $0,0 \%$ & $99,7 \%$ & $0,3 \%$ \\
\hline Ano & $\mathbf{6 , 3 \%}$ & $\mathbf{8 2 , 0} \%$ & $\mathbf{1 1 , 7} \%$ \\
\hline
\end{tabular}

TABELA 12: PORCENTAGEM DE HORAS MENSAIS EM CONFORTO NA FACE SUL ( $10 \%$ DE INSATISFEITOS)

\begin{tabular}{|lccc|}
\hline Mês & Frio & Conforto & Quente \\
\hline Janeiro & $0,0 \%$ & $49,5 \%$ & $50,5 \%$ \\
\hline Fevereiro & $0,0 \%$ & $47,0 \%$ & $53,0 \%$ \\
\hline Março & $0,0 \%$ & $57,8 \%$ & $42,2 \%$ \\
\hline Abril & $0,0 \%$ & $57,8 \%$ & $42,2 \%$ \\
\hline Maio & $0,0 \%$ & $96,9 \%$ & $3,1 \%$ \\
\hline Junho & $1,3 \%$ & $98,7 \%$ & $0,0 \%$ \\
\hline Julho & $0,6 \%$ & $99,4 \%$ & $0,0 \%$ \\
\hline Agosto & $66,7 \%$ & $33,3 \%$ & $0,0 \%$ \\
\hline Setembro & $1,1 \%$ & $98,9 \%$ & $0,0 \%$ \\
\hline Outubro & $0,0 \%$ & $100,0 \%$ & $0,0 \%$ \\
\hline Novembro & $0,0 \%$ & $98,9 \%$ & $1,1 \%$ \\
\hline Dezembro & $0,0 \%$ & $95,2 \%$ & $4,8 \%$ \\
\hline Ano & $\mathbf{1 0 , 5} \%$ & $\mathbf{7 6 , 8} \%$ & $\mathbf{1 2 , 7} \%$ \\
\hline
\end{tabular}


TABELA 13: PORCENTAGEM DE HORAS MENSAIS EM CONFORTO NA FACE NORDESTE - NE (10 \% DE INSATISFEITOS)

\begin{tabular}{|lccc|}
\hline Mês & Frio & Conforto & Quente \\
\hline Janeiro & $0,0 \%$ & $33,6 \%$ & $66,4 \%$ \\
\hline Fevereiro & $0,0 \%$ & $6,5 \%$ & $93,5 \%$ \\
\hline Março & $0,0 \%$ & $22,6 \%$ & $77,4 \%$ \\
\hline Abril & $0,0 \%$ & $22,6 \%$ & $77,4 \%$ \\
\hline Maio & $0,0 \%$ & $15,3 \%$ & $84,7 \%$ \\
\hline Junho & $0,0 \%$ & $96,5 \%$ & $3,5 \%$ \\
\hline Julho & $0,0 \%$ & $100,0 \%$ & $0,0 \%$ \\
\hline Agosto & $1,3 \%$ & $98,7 \%$ & $0,0 \%$ \\
\hline Setembro & $0,0 \%$ & $100,0 \%$ & $0,0 \%$ \\
\hline Outubro & $0,0 \%$ & $100,0 \%$ & $0,0 \%$ \\
\hline Novembro & $0,0 \%$ & $96,9 \%$ & $3,1 \%$ \\
\hline Dezembro & $0,0 \%$ & $87,1 \%$ & $12,9 \%$ \\
\hline Ano & $\mathbf{0 , 1} \%$ & $\mathbf{7 1 , 9} \%$ & $\mathbf{2 8 , 0 \%}$ \\
\hline
\end{tabular}

TABELA 14: PORCENTAGEM DE HORAS MENSAIS EM CONFORTO NA FACE SUDOESTE - SO (10\% DE INSATISFEITOS)

\begin{tabular}{|lccc|}
\hline Mês & Frio & Conforto & Quente \\
\hline Janeiro & $0,0 \%$ & $50,5 \%$ & $49,5 \%$ \\
\hline Fevereiro & $0,0 \%$ & $31,8 \%$ & $68,2 \%$ \\
\hline Março & $0,0 \%$ & $47,3 \%$ & $52,7 \%$ \\
\hline Abril & $0,0 \%$ & $47,3 \%$ & $52,7 \%$ \\
\hline Maio & $0,0 \%$ & $95,3 \%$ & $4,7 \%$ \\
\hline Junho & $0,3 \%$ & $99,7 \%$ & $0,0 \%$ \\
\hline Julho & $0,0 \%$ & $100,0 \%$ & $0,0 \%$ \\
\hline Agosto & $65,1 \%$ & $34,9 \%$ & $0,0 \%$ \\
\hline Setembro & $0,0 \%$ & $100,0 \%$ & $0,0 \%$ \\
\hline Outubro & $0,0 \%$ & $100,0 \%$ & $0,0 \%$ \\
\hline Novembro & $0,0 \%$ & $98,6 \%$ & $1,4 \%$ \\
\hline Dezembro & $0,0 \%$ & $94,4 \%$ & $5,6 \%$ \\
\hline Ano & $\mathbf{9 , 3} \%$ & $\mathbf{7 5 , 8 \%}$ & $\mathbf{1 4 , 9 \%}$ \\
\hline
\end{tabular}


TABELA 15: PORCENTAGEM DE HORAS MENSAIS EM CONFORTO NA FACE LESTE - E (10\% DE INSATISFEITOS)

\begin{tabular}{|lccc|}
\hline Mês & Frio & Conforto & Quente \\
\hline Janeiro & $0,0 \%$ & $49,2 \%$ & $50,8 \%$ \\
\hline Fevereiro & $0,0 \%$ & $24,7 \%$ & $75,3 \%$ \\
\hline Março & $0,0 \%$ & $38,2 \%$ & $61,8 \%$ \\
\hline Abril & $0,0 \%$ & $38,2 \%$ & $61,8 \%$ \\
\hline Maio & $0,0 \%$ & $80,8 \%$ & $19,2 \%$ \\
\hline Junho & $0,0 \%$ & $100,0 \%$ & $0,0 \%$ \\
\hline Julho & $0,0 \%$ & $100,0 \%$ & $0,0 \%$ \\
\hline Agosto & $53,2 \%$ & $46,8 \%$ & $0,0 \%$ \\
\hline Setembro & $0,0 \%$ & $100,0 \%$ & $0,0 \%$ \\
\hline Outubro & $0,0 \%$ & $100,0 \%$ & $0,0 \%$ \\
\hline Novembro & $0,0 \%$ & $98,6 \%$ & $1,4 \%$ \\
\hline Dezembro & $0,0 \%$ & $94,1 \%$ & $5,9 \%$ \\
\hline Ano & $\mathbf{6 , 9} \%$ & $\mathbf{7 5 , 5} \%$ & $\mathbf{1 7 , 5 \%}$ \\
\hline
\end{tabular}

TABELA 16: PORCENTAGEM DE HORAS MENSAIS EM CONFORTO NA FACE OESTE - O (10\% DE INSATISFEITOS)

\begin{tabular}{|lccc|}
\hline Mês & Frio & Conforto & Quente \\
\hline Janeiro & $0,0 \%$ & $23,1 \%$ & $76,9 \%$ \\
\hline Fevereiro & $0,0 \%$ & $3,3 \%$ & $96,7 \%$ \\
\hline Março & $0,0 \%$ & $23,9 \%$ & $76,1 \%$ \\
\hline Abril & $0,0 \%$ & $23,9 \%$ & $76,1 \%$ \\
\hline Maio & $0,0 \%$ & $23,1 \%$ & $76,9 \%$ \\
\hline Junho & $0,0 \%$ & $100,0 \%$ & $0,0 \%$ \\
\hline Julho & $0,0 \%$ & $100,0 \%$ & $0,0 \%$ \\
\hline Agosto & $27,7 \%$ & $72,3 \%$ & $0,0 \%$ \\
\hline Setembro & $0,0 \%$ & $100,0 \%$ & $0,0 \%$ \\
\hline Outubro & $0,0 \%$ & $100,0 \%$ & $0,0 \%$ \\
\hline Novembro & $0,0 \%$ & $92,2 \%$ & $7,8 \%$ \\
\hline Dezembro & $0,0 \%$ & $76,3 \%$ & $23,7 \%$ \\
\hline Ano & $\mathbf{2 , 8 \%}$ & $\mathbf{6 7 , 8 \%}$ & $\mathbf{2 9 , 4 \%}$ \\
\hline
\end{tabular}


TABELA 17: PORCENTAGEM DE HORAS MENSAIS EM CONFORTO NA FACE SUDESTE - SE (10\% DE INSATISFEITOS)

\begin{tabular}{|lccc|}
\hline Mês & Frio & Conforto & Quente \\
\hline Janeiro & $0,0 \%$ & $50,8 \%$ & $49,2 \%$ \\
\hline Fevereiro & $0,0 \%$ & $34,8 \%$ & $65,2 \%$ \\
\hline Março & $0,0 \%$ & $50,3 \%$ & $49,7 \%$ \\
\hline Abril & $0,0 \%$ & $50,3 \%$ & $49,7 \%$ \\
\hline Maio & $0,0 \%$ & $96,7 \%$ & $3,3 \%$ \\
\hline Junho & $0,5 \%$ & $99,5 \%$ & $0,0 \%$ \\
\hline Julho & $0,0 \%$ & $100,0 \%$ & $0,0 \%$ \\
\hline Agosto & $66,1 \%$ & $33,9 \%$ & $0,0 \%$ \\
\hline Setembro & $0,0 \%$ & $100,0 \%$ & $0,0 \%$ \\
\hline Outubro & $0,0 \%$ & $100,0 \%$ & $0,0 \%$ \\
\hline Novembro & $0,0 \%$ & $98,6 \%$ & $1,4 \%$ \\
\hline Dezembro & $0,0 \%$ & $95,2 \%$ & $4,8 \%$ \\
\hline Ano & $\mathbf{9 , 7} \%$ & $\mathbf{7 6 , 1} \%$ & $\mathbf{1 4 , 2} \%$ \\
\hline
\end{tabular}

TABELA 18: PORCENTAGEM DE HORAS MENSAIS EM CONFORTO NA FACE NOROESTE - NO (10\% DE INSATISFEITOS)

\begin{tabular}{|lccc|}
\hline Mês & Frio & Conforto & Quente \\
\hline Janeiro & $0,0 \%$ & $37,9 \%$ & $32,1 \%$ \\
\hline Fevereiro & $0,0 \%$ & $8,6 \%$ & $91,4 \%$ \\
\hline Março & $0,0 \%$ & $24,2 \%$ & $75,8 \%$ \\
\hline Abril & $0,0 \%$ & $24,2 \%$ & $75,8 \%$ \\
\hline Maio & $0,0 \%$ & $15,6 \%$ & $84,4 \%$ \\
\hline Junho & $0,0 \%$ & $95,2 \%$ & $4,8 \%$ \\
\hline Julho & $0,0 \%$ & $100,0 \%$ & $0,0 \%$ \\
\hline Agosto & $0,5 \%$ & $99,5 \%$ & $0,0 \%$ \\
\hline Setembro & $0,0 \%$ & $100,0 \%$ & $0,0 \%$ \\
\hline Outubro & $0,0 \%$ & $100,0 \%$ & $0,0 \%$ \\
\hline Novembro & $0,0 \%$ & $98,1 \%$ & $1,9 \%$ \\
\hline Dezembro & $0,0 \%$ & $92,2 \%$ & $7,8 \%$ \\
\hline Ano & $\mathbf{0 , 0} \%$ & $\mathbf{7 3 , 1} \%$ & $\mathbf{2 6 , 9} \%$ \\
\hline
\end{tabular}




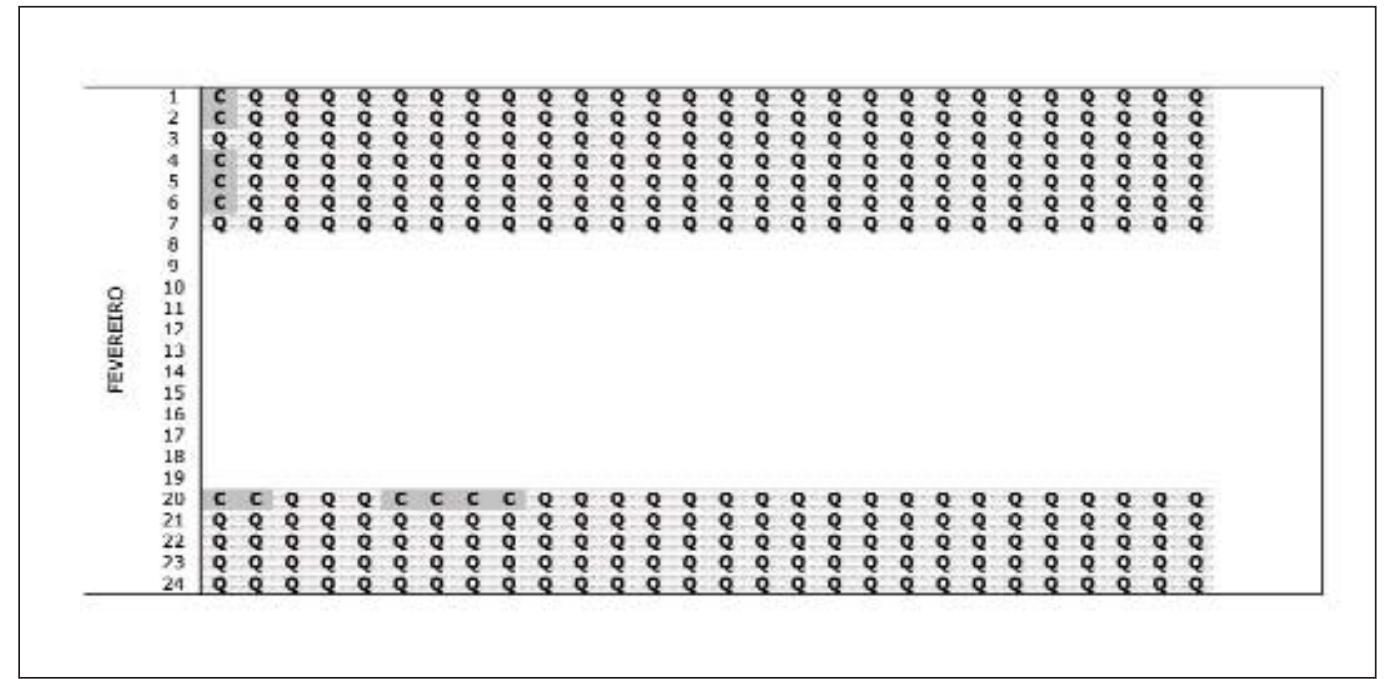

Ilustração 72: Balanço horário de fevereiro, com 10\% de insatisfeitos.

\subsubsection{Variação dos componentes $-3^{\mathrm{a}}$ etapa}

Definida a orientação mais desfavorável, oeste, foram realizadas as alterações no modelo em diversos Cenários:

Cenário o - Alteração dos dados climáticos do modelo calibrado para os dados do arquivo climático anual De Benedetto (2006). As condições internas iniciais do modelo base foram mantidas - janelas fechadas e taxa de infiltração e ventilação (24 horas) e com as características construtivas apresentadas no Apêndice D;

Cenário 1 - Alteração com base no modelo do Cenário o, considerando as condições internas definidas para o modo misto - o SAC será acionado quando os limites de temperatura estiverem fora da faixa de conforto determinada pelo modelo adaptativo (as janelas abrirão quando as condições externas forem consideradas favoráveis de acordo com os valores colocados no software);

Cenário 2 - Baseado no Cenário 1 alterando o vidro para refletivo incolor (sgcool) de $8 \mathrm{~mm}$, com transmissão solar de 0, 016 (mantendo a cortina);

Cenário 3 - Baseado no Cenário 2, mantendo o mesmo vidro porém, excluindo a cortina interna;

Cenário 4 - Mesmas condições do que as do Cenário 1, porém sem cortina;

Cenário 5 - Baseado no Cenário 4, porém alterando o schedule da ventilação (das 11 ás 17 horas);

Cenário 6 - Baseado no Cenário 1, porém alterando o schedule da ventilação (das 11ás 17 horas). 


\subsubsection{Análise dos resultados}

A análise dos Cenários foi feita de duas formas:

- Nos dias representativos de inverno e de verão, foram calculados os ganhos e perdas devido aos resultados obtidos no modelo paramétrico. Foram consideradas: as trocas internas, a condução pelos componentes opacos e transparentes, os ganhos internos (devido à iluminação, pessoas e equipamentos), os ganhos solares, a ventilação e a carga latente e sensivel.

- Ao longo de todo ano, em que foram extraídos do software os resultados da carga sensivel (em W), a carga a ser removida pelo SAC. O software interpreta o acionamento do SAC - tanto para aquecimento quanto para resfriamento - quando as condições internas não estão dentro dos limites estabelecidos na parametrização do modelo, visando manter os usuários dentro dos limites de conforto estabelecidos.

Nas ILs.73 e 74, com as janelas fechadas, verifica-se que, no dia de verão, ocorreu uma perda por meio da condução nos componentes opacos no início e final do dia e, ao mesmo tempo, um ganho pela ventilação. A condução pelos componentes transparentes foi pequena no verão, no entanto, no inverno, a perda de calor por este componente foi mais significativa.

Como não foi considerada a abertura de janelas, a temperatura interna no verão esteve mais próxima da externa às 14 horas do dia representativo de verão (IL. 75), e as maiores diferenças podem ser notadas no inverno, quando externamente a temperatura é de $14,60^{\circ} \mathrm{C}$ e internamente, $22,50^{\circ} \mathrm{C}$, dentro dos limites aceitáveis de conforto.

O modo misto, que foi simulado no Cenário 1 baseia-se na utilização do SAC e da abertura de janelas para atingir os limites determinado para o conforto dos usuários. Verifica-se que, no verão (IL. 76), houve perda de calor no período noturno devido à ventilação. Neste dia, o software considerou a abertura de janelas para manter as condições de conforto internas.

Comparando as ILs. 73 e 74 (Cenário o) com as ILs. 76 e 77 (Cenário 1), verifica-se que com as janelas fechadas (Cenário o) ocorreu uma variação menor da ventilação, principalmente no dia representativo de verão. Neste período, no Cenário 1 verifica-se que a condução pelos componentes opacos acompanha os ganhos solares. No período noturno, estes ganhos por condução são superiores no verão, e inferiores no inverno.

Considerando o Cenário 2, a ventilação auxilia na perda de calor, devido aos componentes opacos e os ganhos internos. No entanto, no inverno (IL. 79), a mesma ventilação é a maior fonte de perda do calor acumulado durante o dia, e implica diretamente no aumento do consumo de energia pelo SAC - lembrandose que no inverno, esta perda de calor é indesejável. 


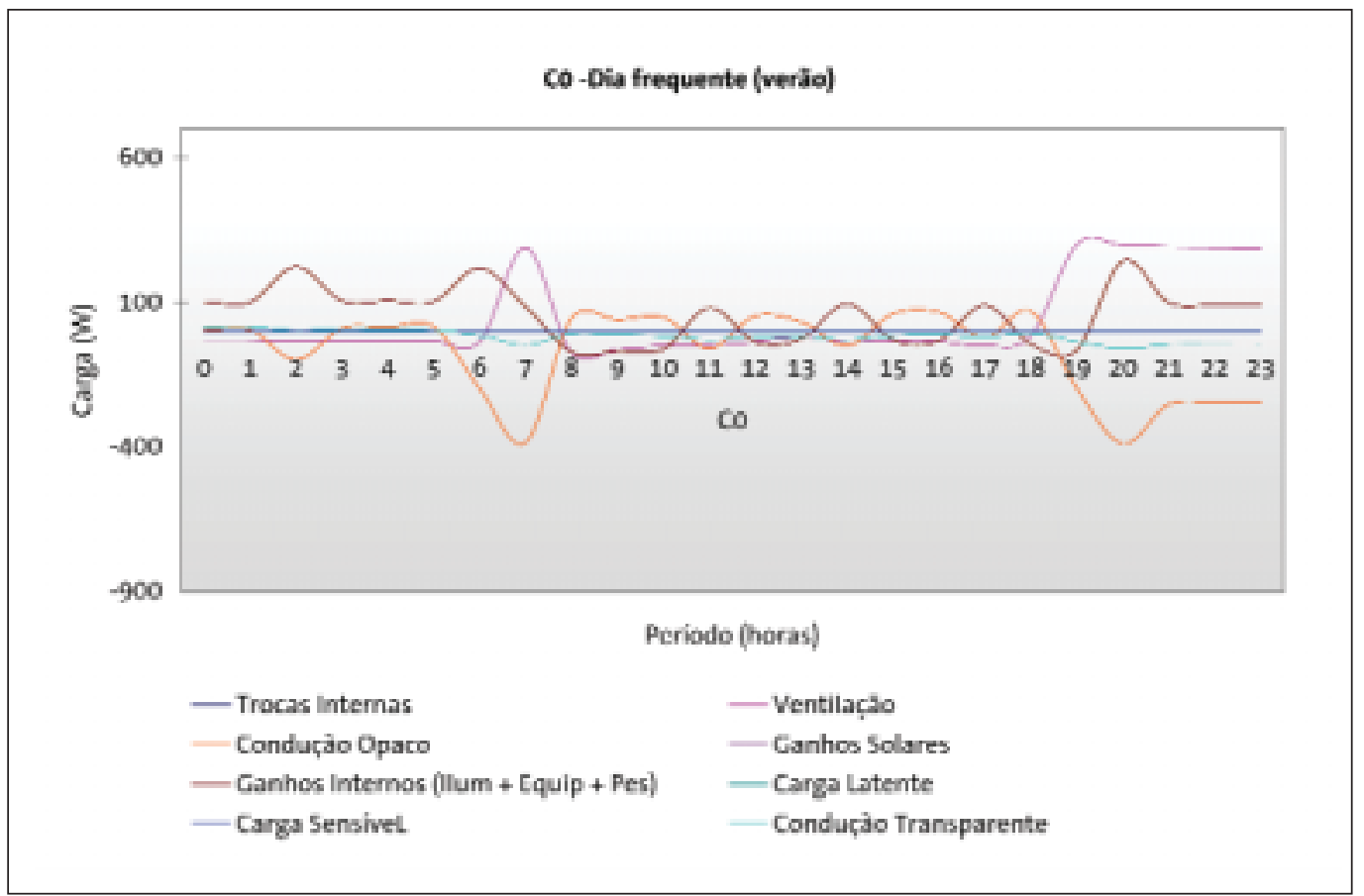

Ilustração 73: Ganhos e Perdas do Cenário o - verão.

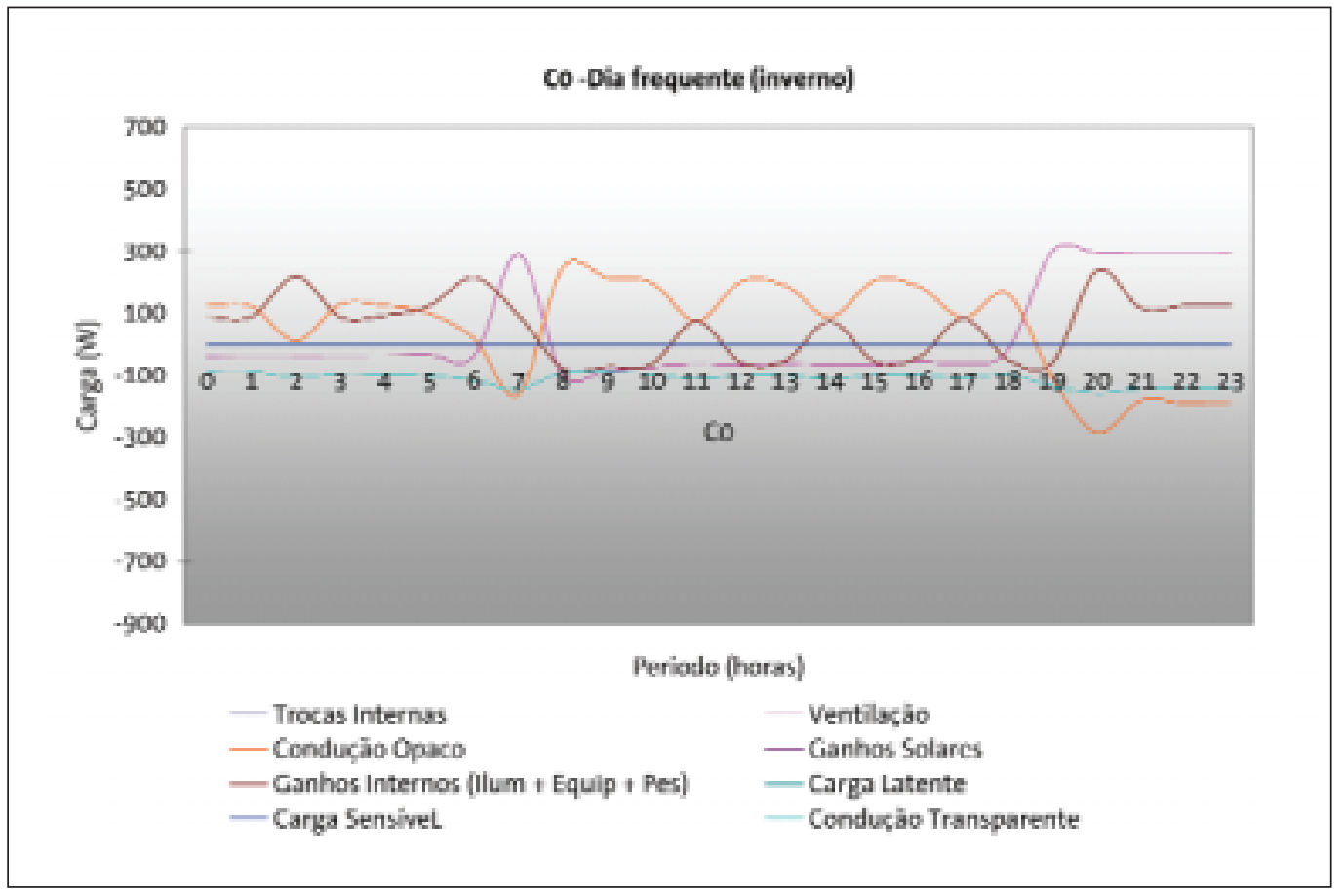

Ilustração 74: Ganhos e Perdas do Cenário o - inverno. 


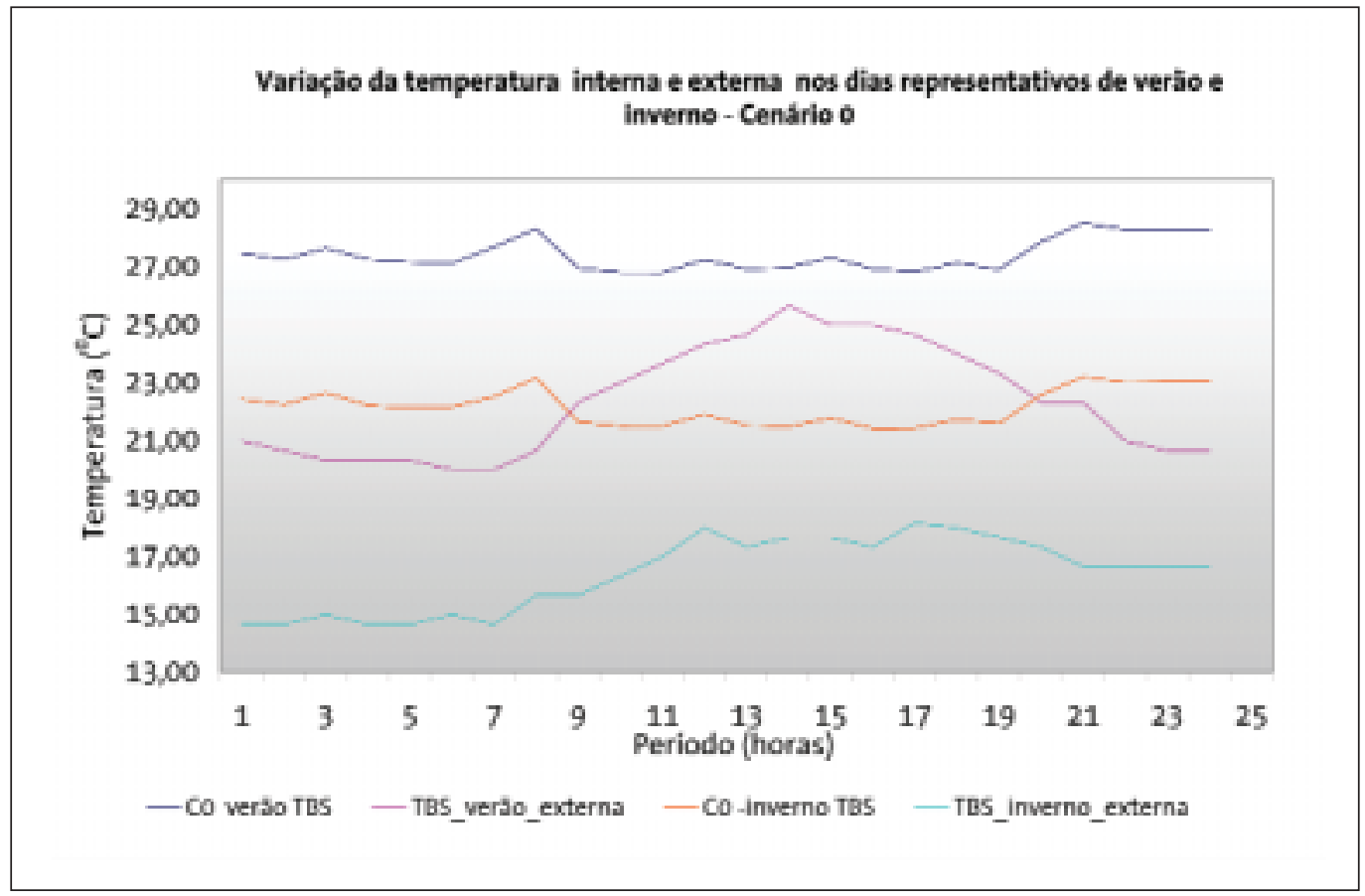

Ilustração 75: Variação da temperatura interna e externa no dia representativo de verão e inverno Cenário o

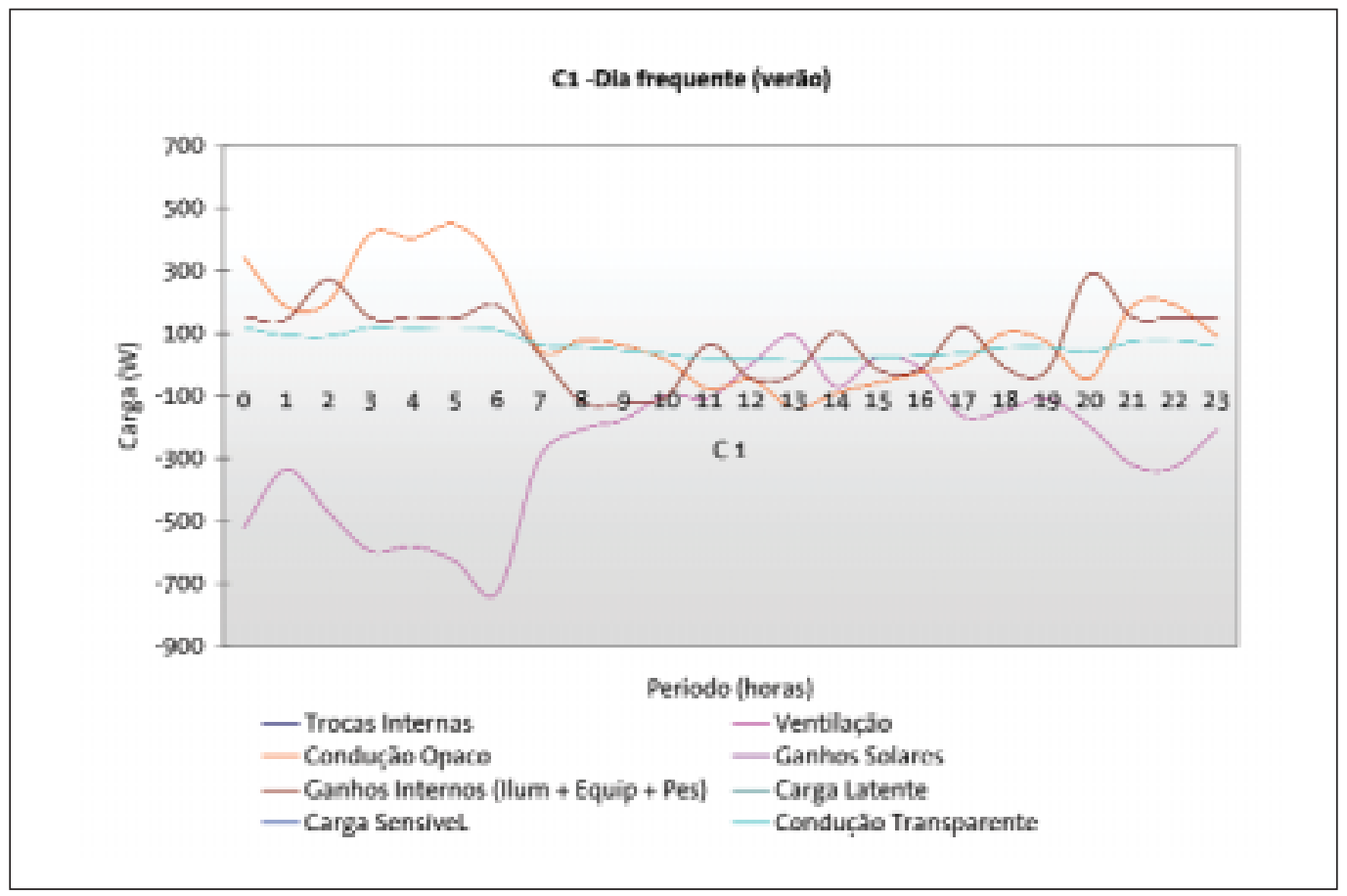

Ilustração 76: Ganhos e Perdas do Cenário 1 - verão 


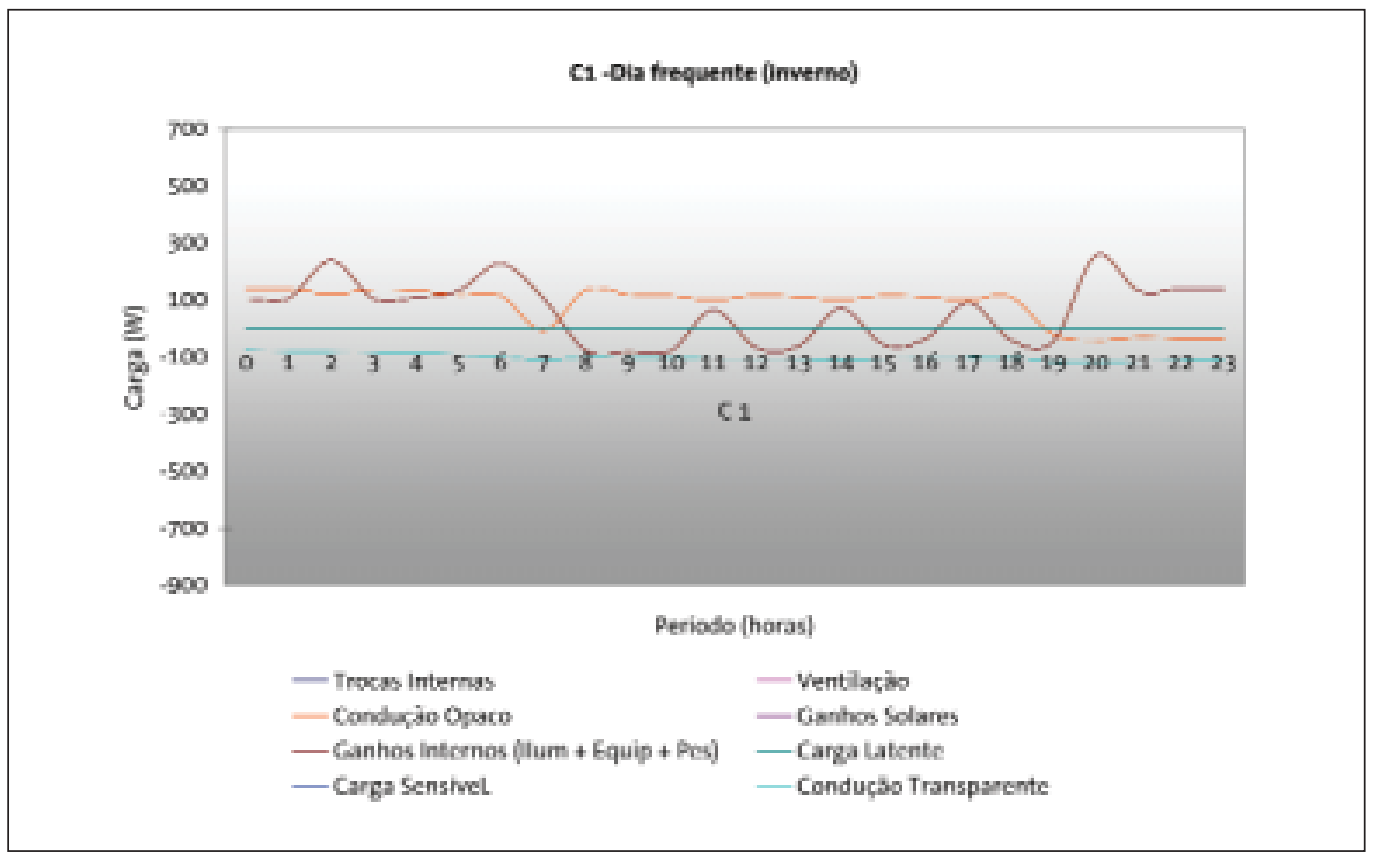

Ilustração 77: Ganhos e Perdas do Cenário 1- inverno.

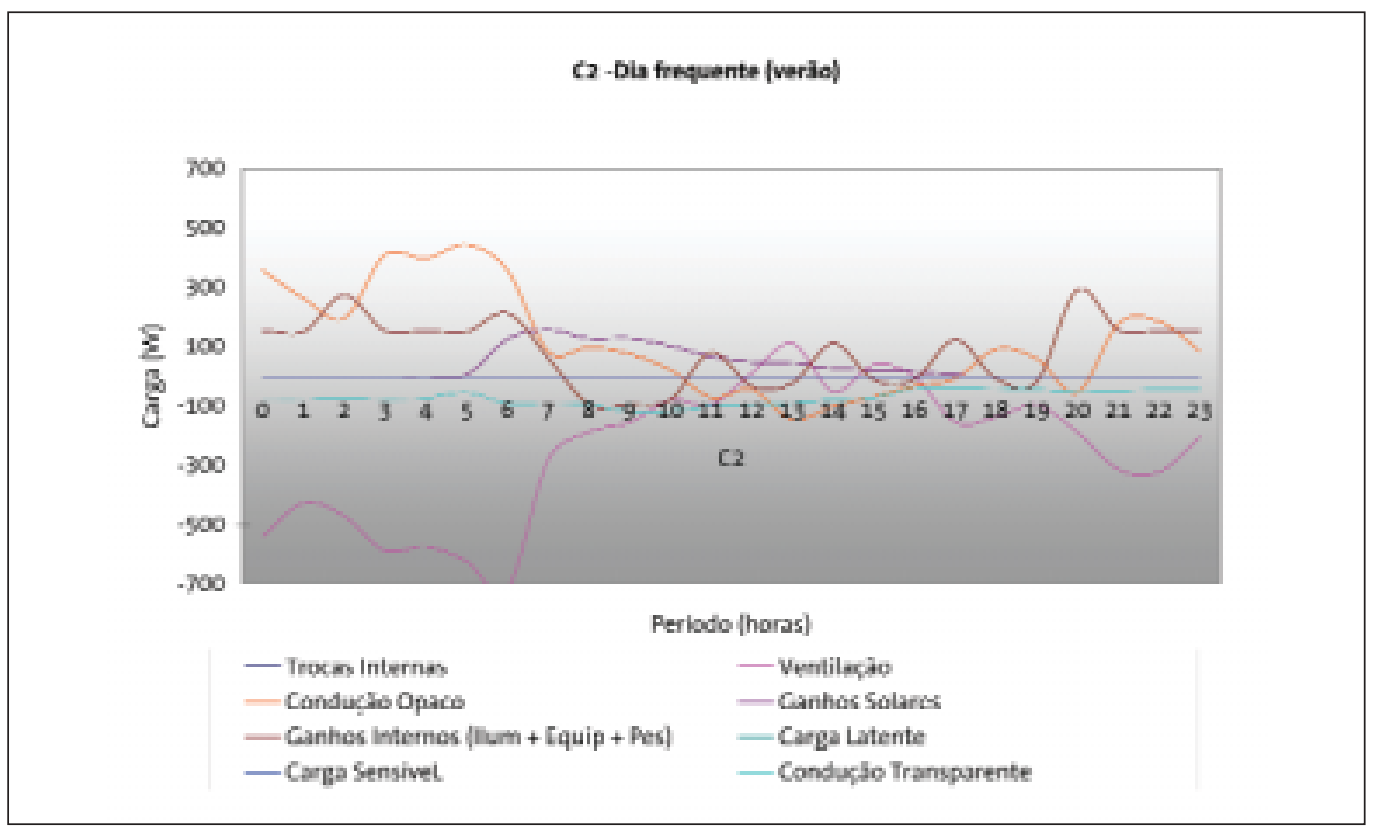

Ilustração 78: Ganhos e Perdas do Cenário 2 - verão.

No Cenário 3, mantendo as características do vidro, excluindo apenas a cortina e mantendo a mesma ventilação do caso anterior, verifica-se, na IL. 80, no verão, um aumento dos ganhos solares em relação ao Cenário 2, na IL. 78.

No dia representativo de inverno, a ausência da cortina favoreceu a redução das trocas internas, porém uma análise do consumo de energia anual devido ao SAC é importante para uma melhor análise (feita posteriormente). 


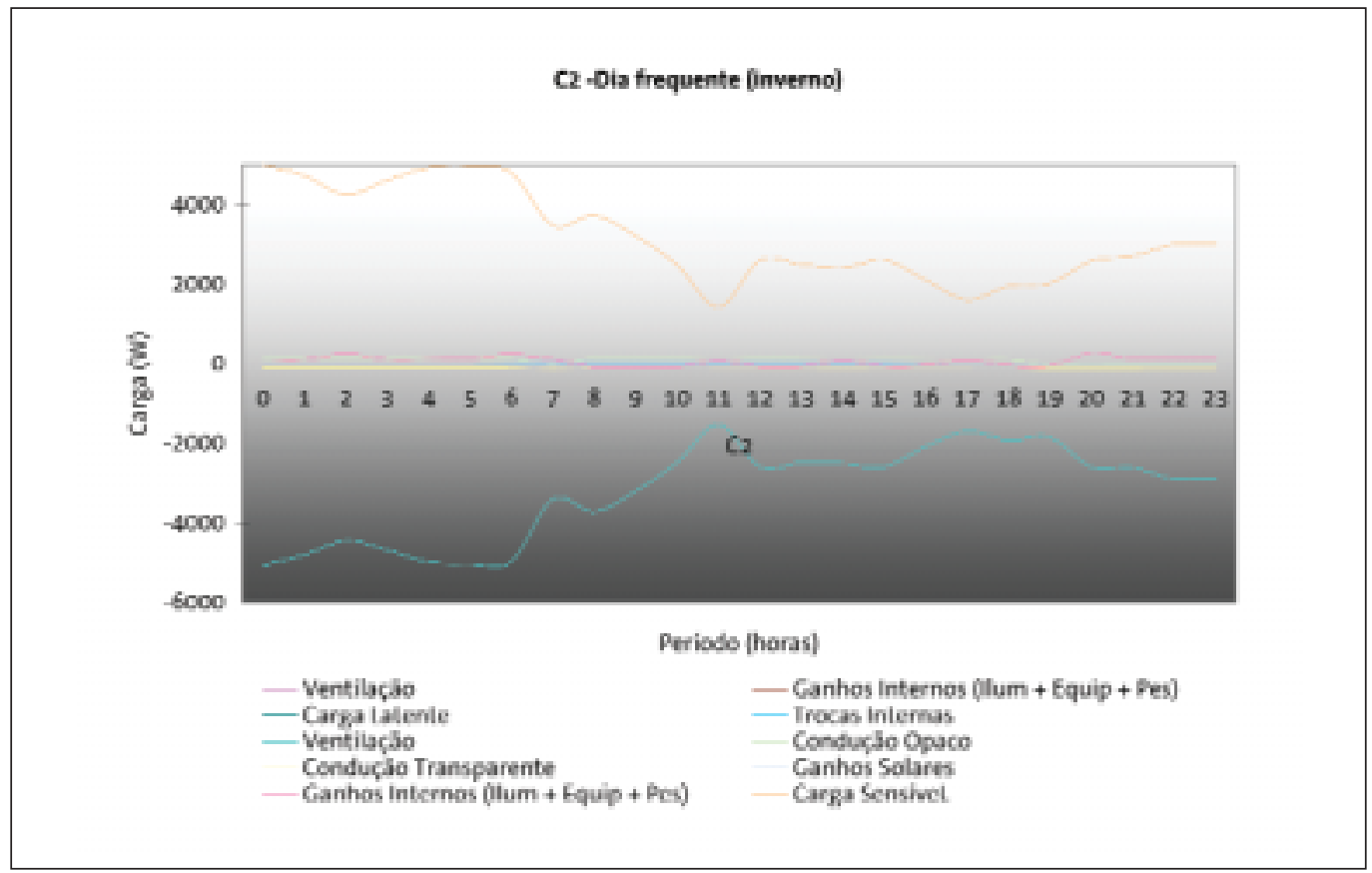

Ilustração 79: Ganhos e Perdas do Cenário 2-inverno.

Na IL. 82, nota-se que, no verão, as temperaturas internas e externas oscilaram e que o SAC não foi acionado no modelo paramétrico. No entanto, a temperatura externa do inverno foi inferior ao limites mínimos definidos (de $20,6^{\circ} \mathrm{C}$ ), que o SAC foi acionado, mantendo a temperatura do ar interno constante.

A ausência de cortina interna no Cenário 4, baseado nas características do Cenário 1, mesmo tipo de vidro e mesma taxa de ventilação auxiliaram no aumento dos ganhos solares no verão (IL. 83). No inverno, na IL. 84, estes ganhos foram menores, devido a menor quantidade de radiação, mas foi mantido o SAC como estratégia para manter as condições de conforto aceitáveis.

Com base no Cenário 4 foi proposto o Cenário 5 , reduzindo o período de ventilação durante o dia. Verificou-se, nas ILs. 85 e 86, que ocorreram menores trocas durante o verão, no entanto, no inverno, a carga sensivel foi inversamente proporcional a carga devido a ventilação.

Para avaliar o impacto da cortina interna nos dias representativos de verão e inverno, foi proposto o Cenário 6, baseado nas características do Cenário 5, com mesmo período da ventilação, tipo de vidro, porém diferenciando-se do anterior devido a existência da cortina interna.

Os ganhos de carga (em W) para os dias avaliados (ILs. 87 e 88) foram próximos aos ocorridos no Cenário 4, como se a redução do período ventilado compensasse o acréscimo da cortina interna. 


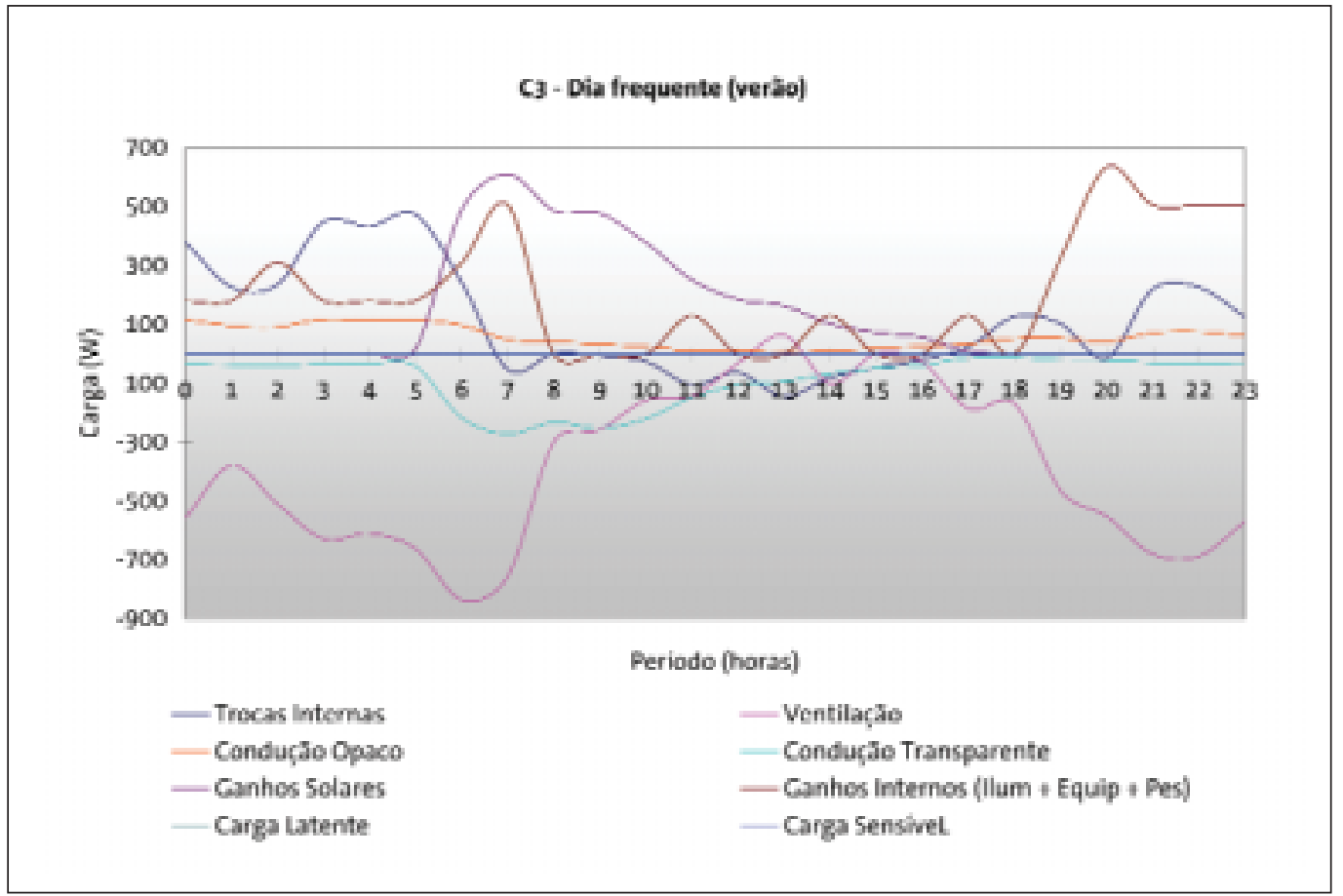

Ilustração 80: Ganhos e Perdas do Cenário 3-verão

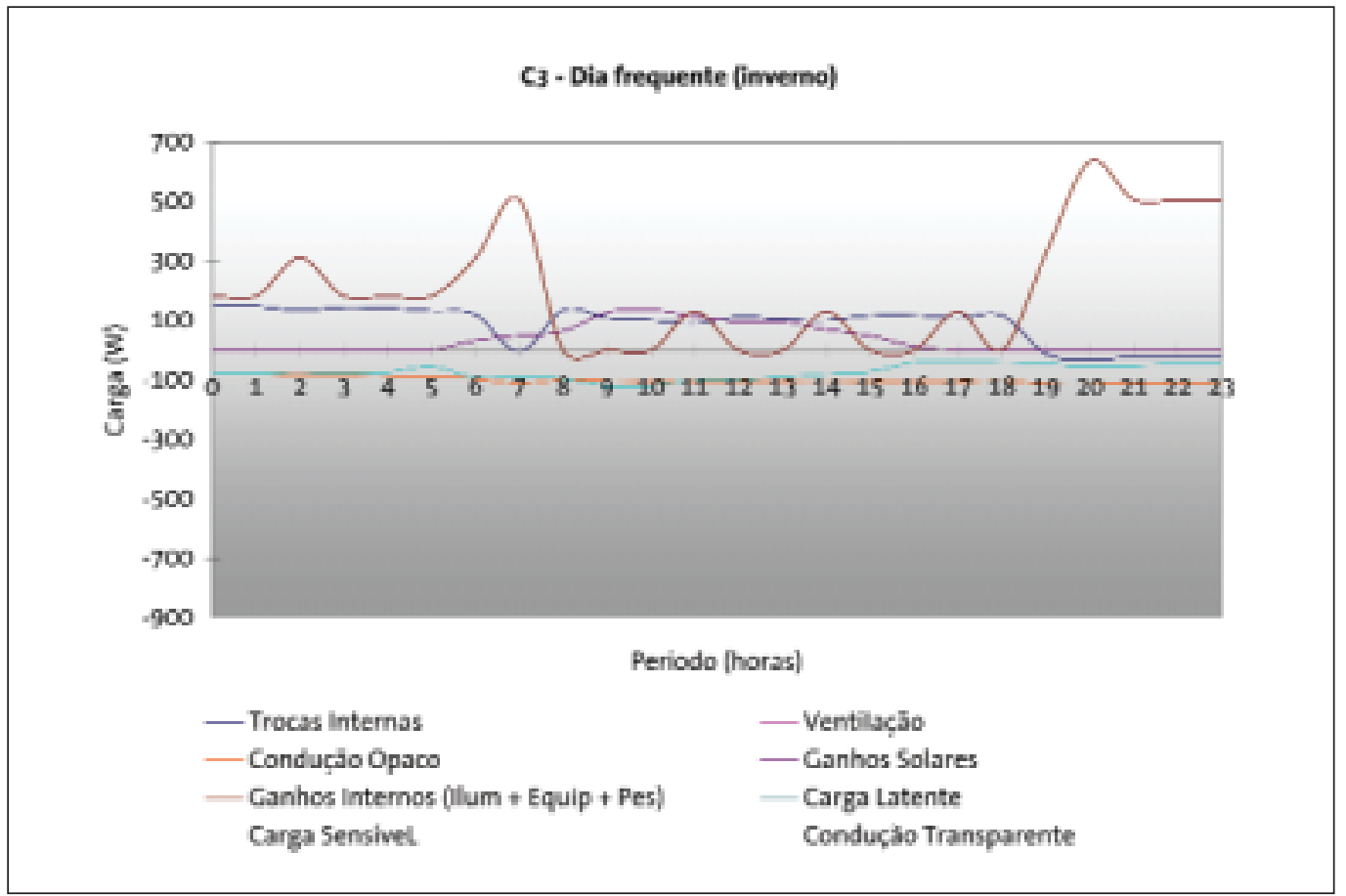

Ilustração 81: Ganhos e Perdas do Cenário 3-inverno 


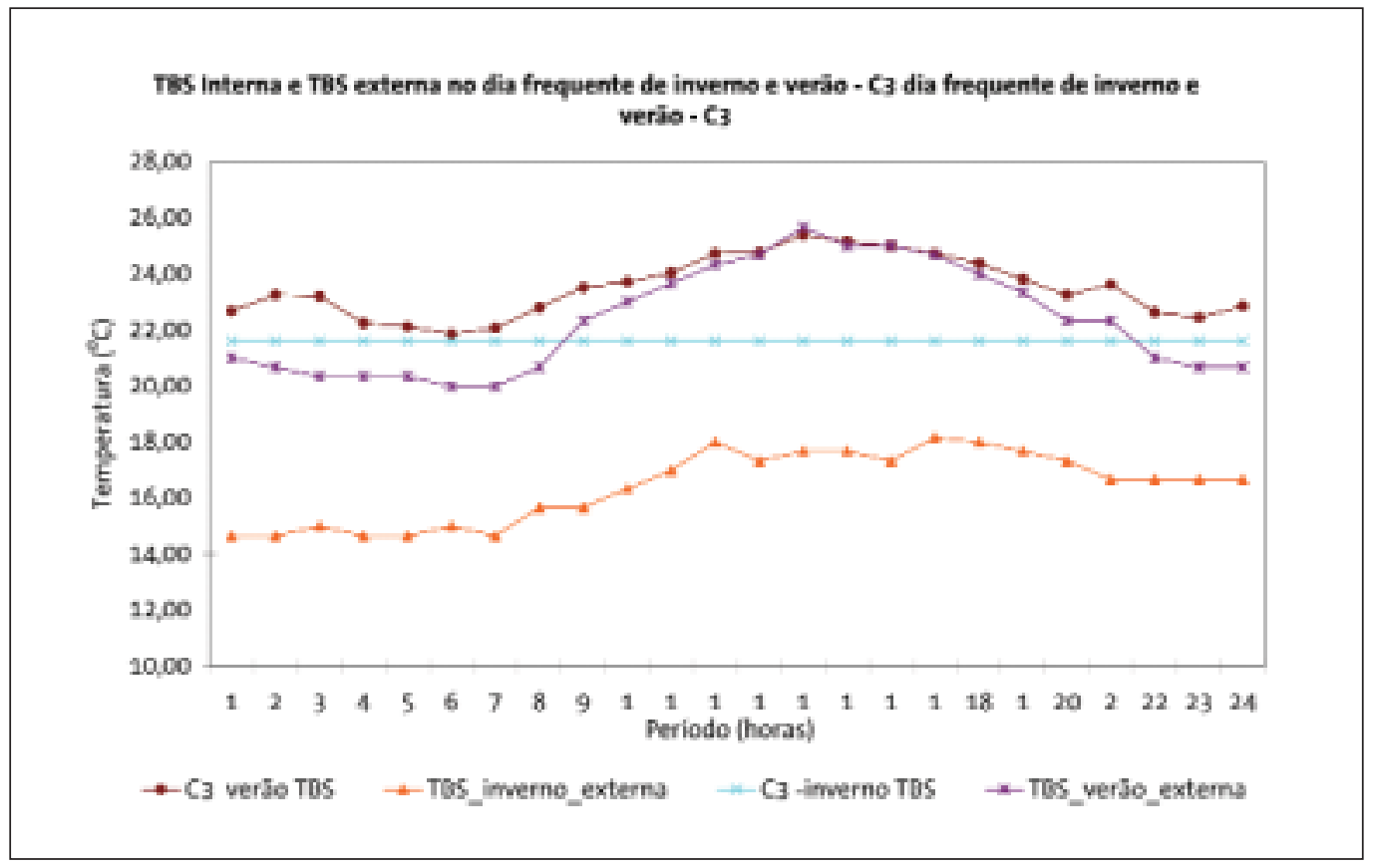

Ilustração 82: Variação da temperatura externa e interna no dia representativo de verão e inverno Cenário 3

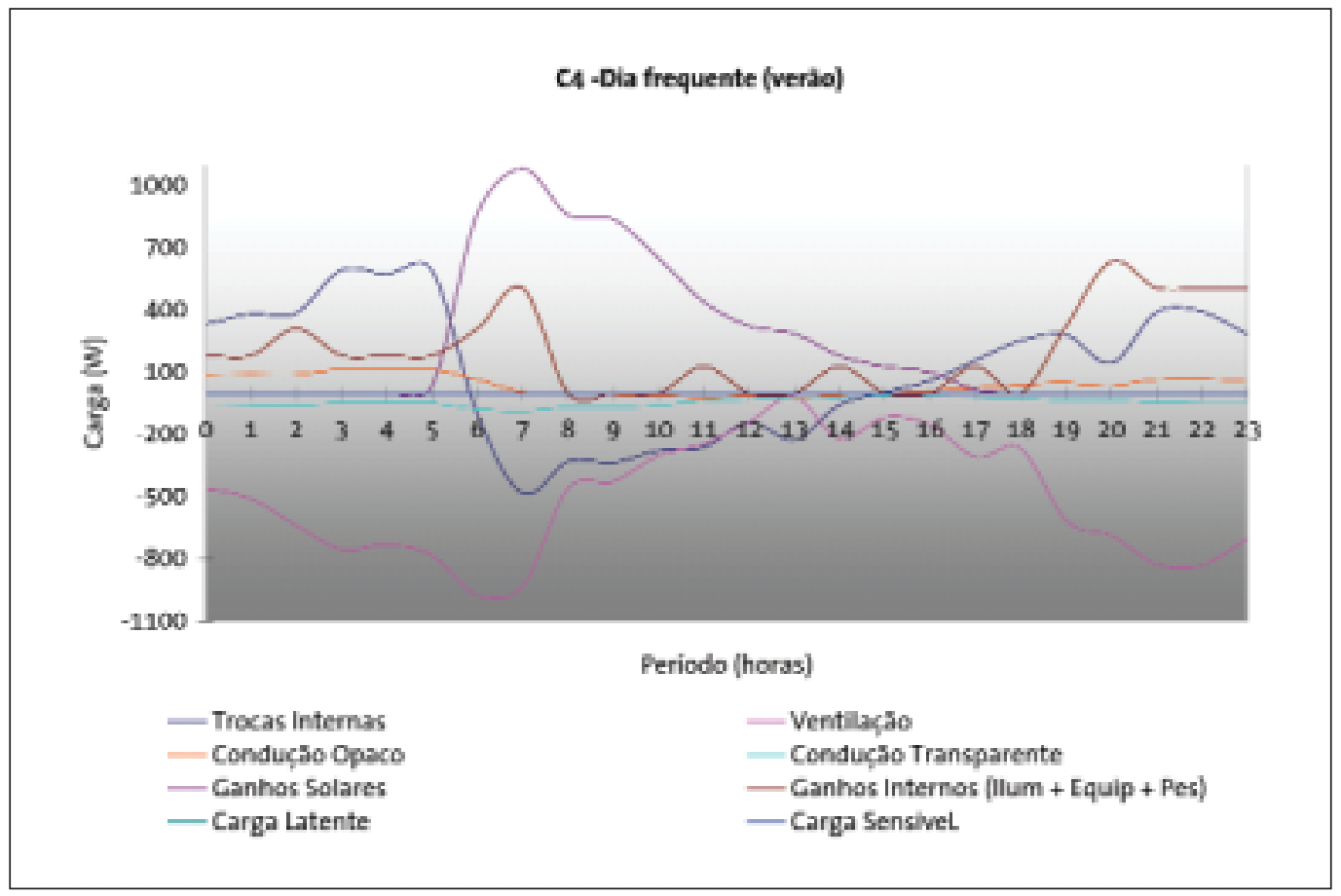

Ilustração 83: Ganhos e Perdas do Cenário 4 - verão 


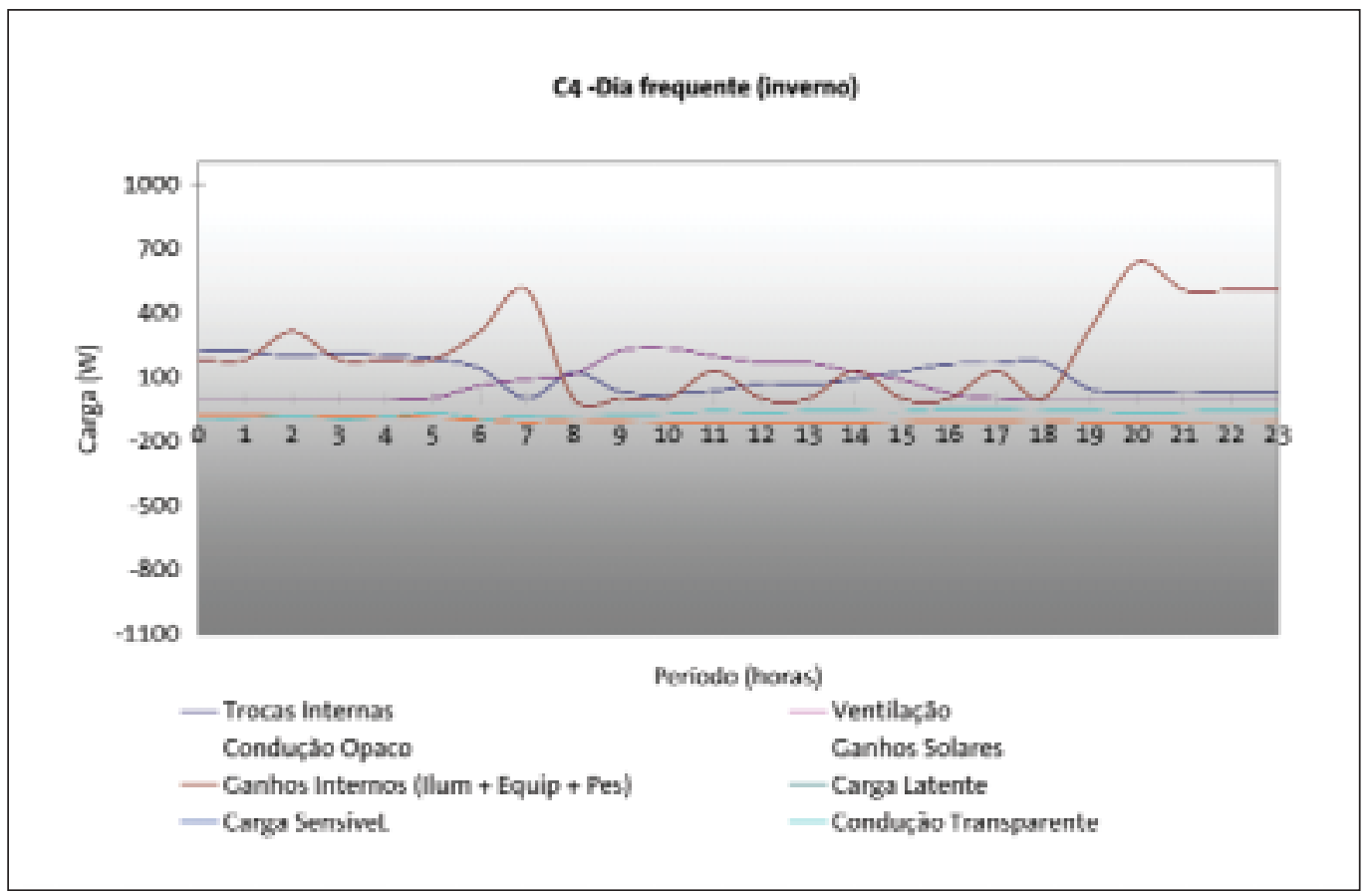

Ilustração 84: Ganhos e Perdas do Cenário 4 - inverno.

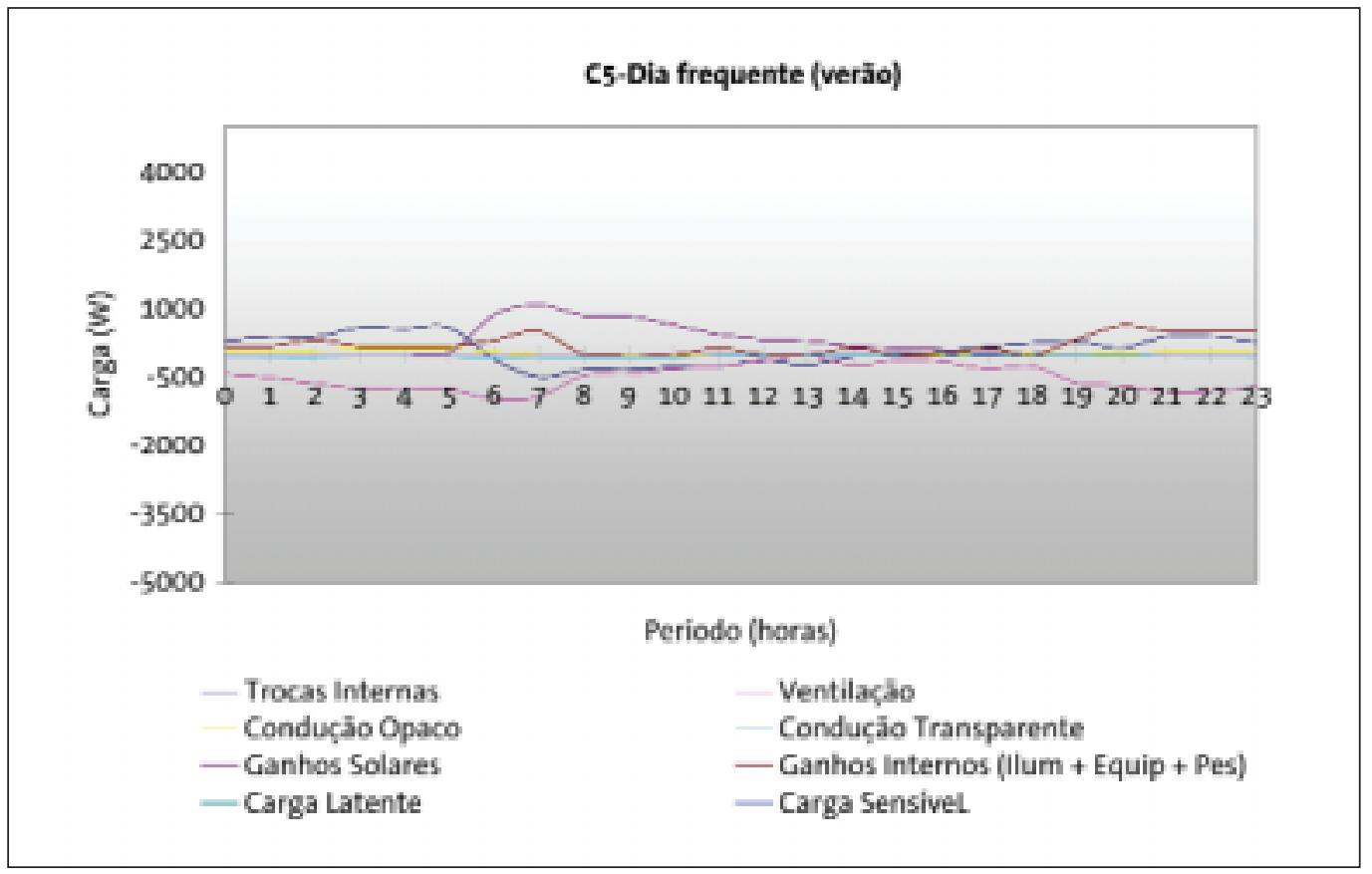

Ilustração 85: Ganhos e Perdas do Cenário 5- verão. 


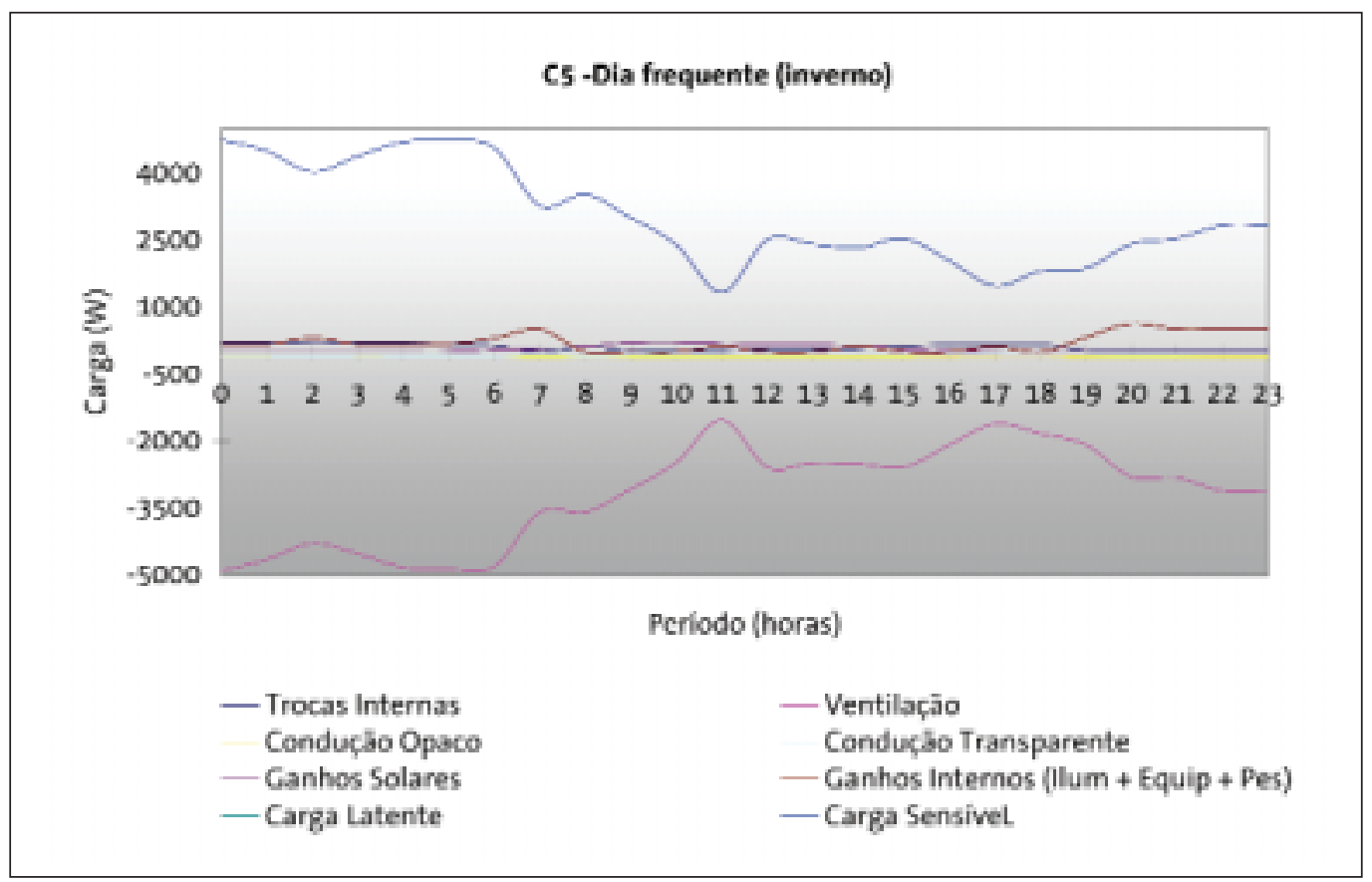

Ilustração 86: Ganhos e Perdas do Cenário 5-inverno.

Na IL. 89 verifica-se que, no verão, a temperatura do ar (TBS) oscila e, portanto, a ventilação foi suficiente para remover os ganhos de calor indesejáveis. No inverno, o SAC foi acionado para manter a TBS interna constante ao longo do dia no valor mínimo determinado pelo modelo adaptativo, que foi adaptado segundo os critérios apresentados na seção 4.1.

\subsubsection{Variação de componente opaco $-4^{\text {a }}$ etapa}

Com base nos Cenários anteriores, foi proposto um novo Cenário, 7:

Cenário 7 - Baseado no Cenário 5, e alterando a composição da parede externa (aumentando o isolamento térmico da parede).

$\mathrm{Na}$ IL. 90 verifica-se que a oscilação de temperaturas internas do ar e de cargas se aproxima dos valores apresentados na IL.89.

Os valores de carga sensível anual resultantes das simulações para cada um dos Cenários, foram calculados separadamente para resfriamento e aquecimento e, no gráfico, apresentado na IL.91 apresenta os resultados comparativos entre todos eles, exceto o caso base (Cenário o).

O Cenário 2 foi o que resultou em maior consumo de energia do que os outros, sendo o consumo para aquecimento o maior responsável para este resultado. Como foi apresentado anteriormente na avaliação do arquivo climático, ao 


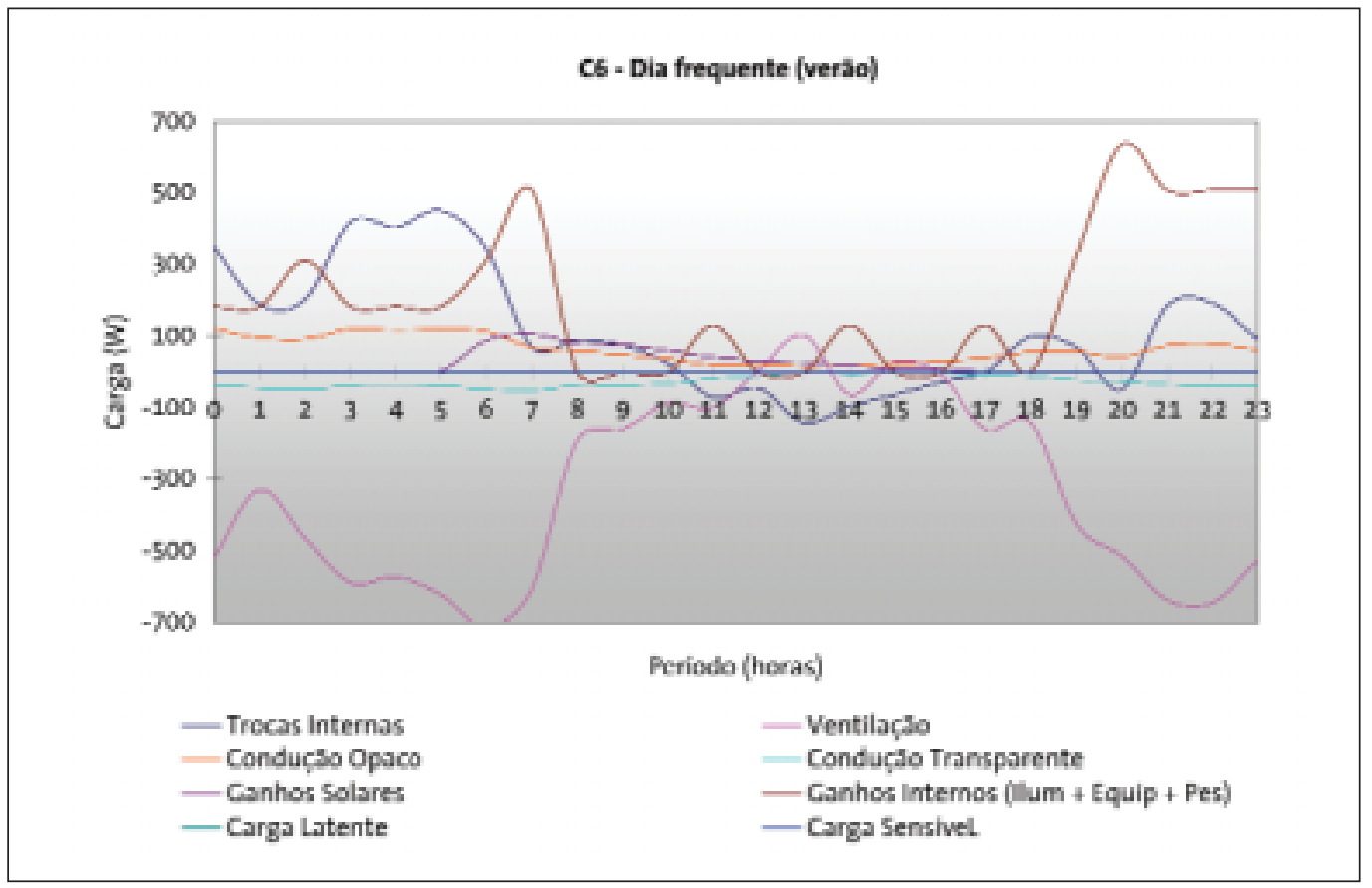

Ilustração 87: Ganhos e Perdas do Cenário 6 - verão

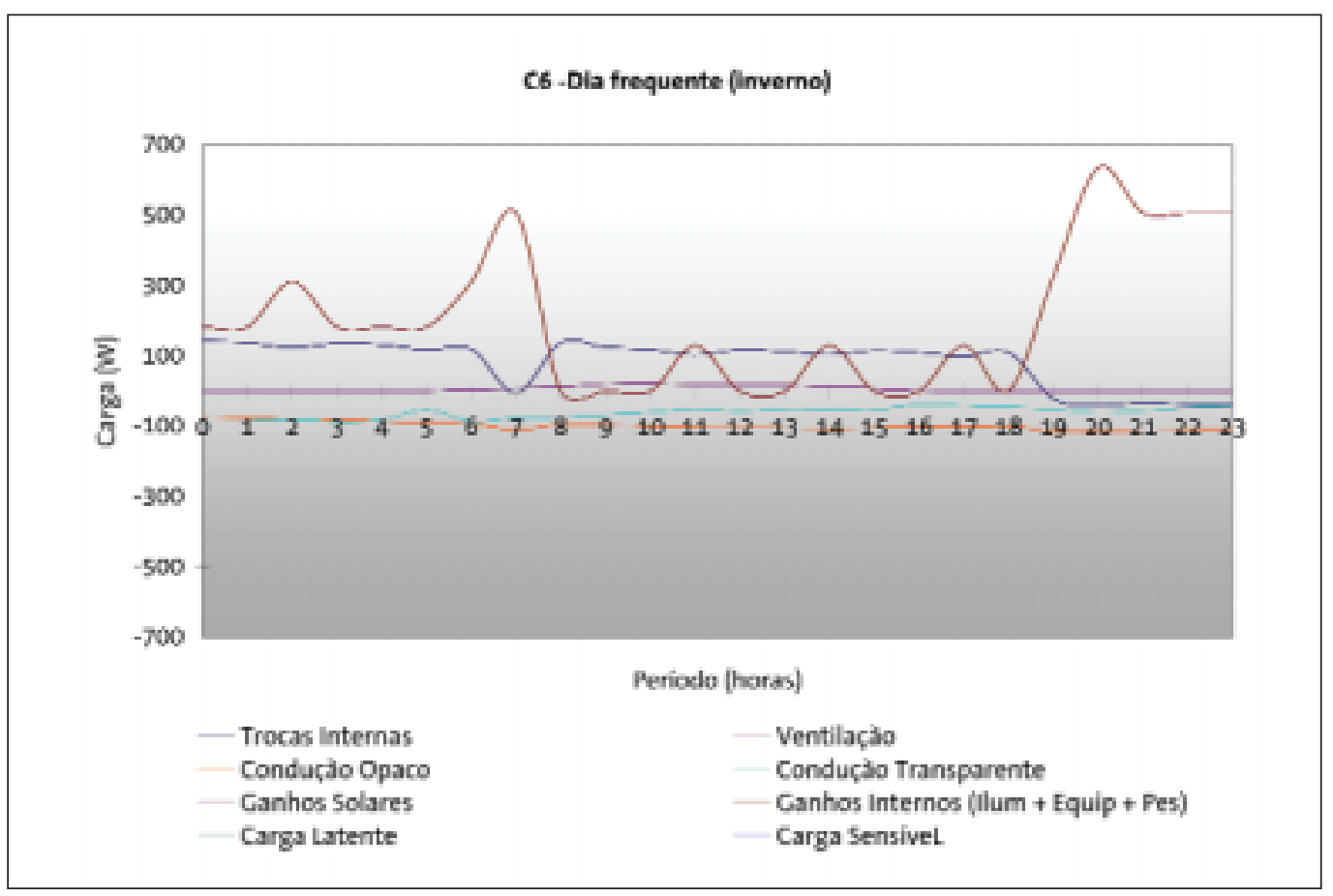

Ilustração 88: Ganhos e Perdas do Cenário 6 - inverno 


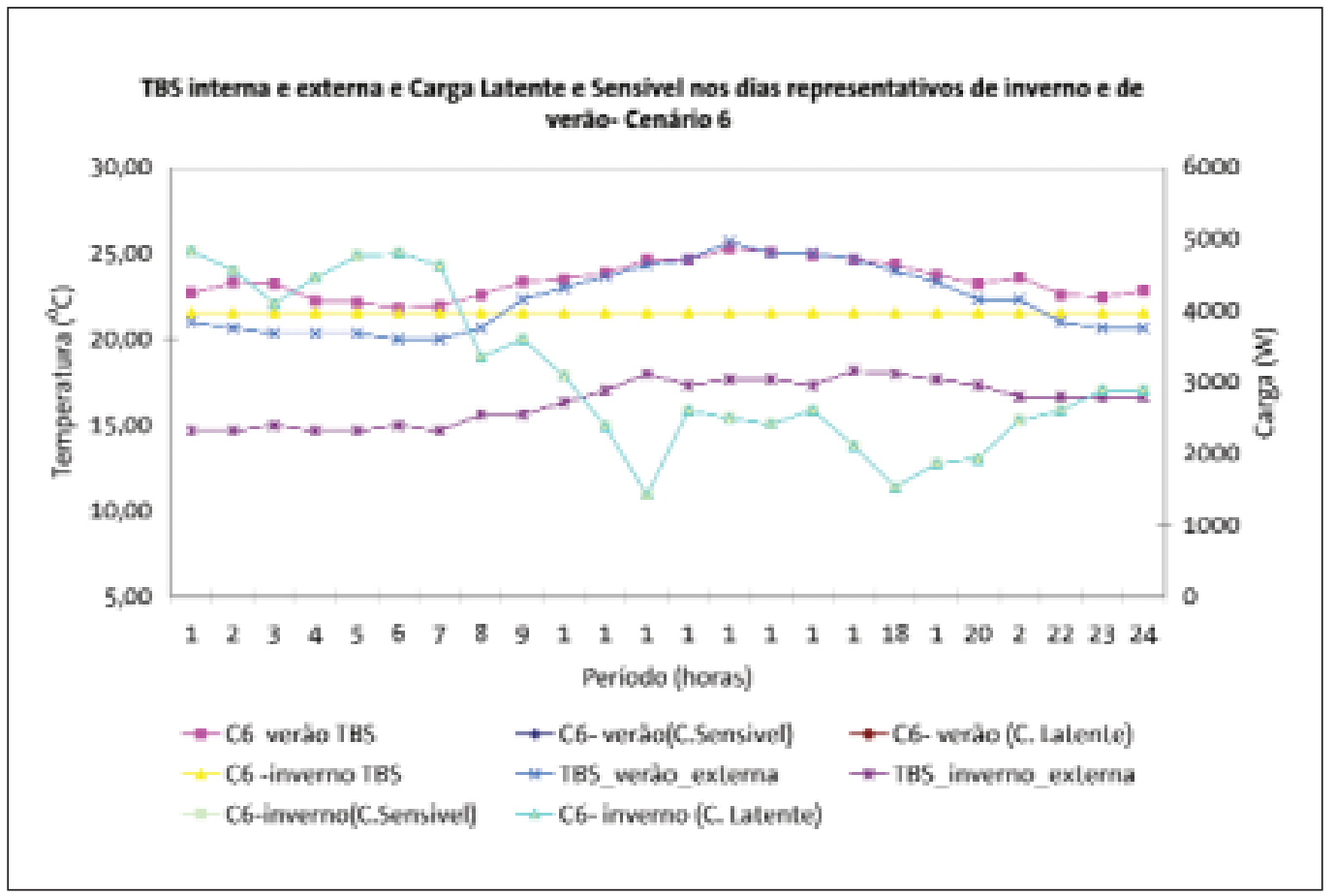

Ilustração 89: TBS interna e externa e carga Latente e Sensivel nos dias representativos de inverno e de verão - Cenário 6.

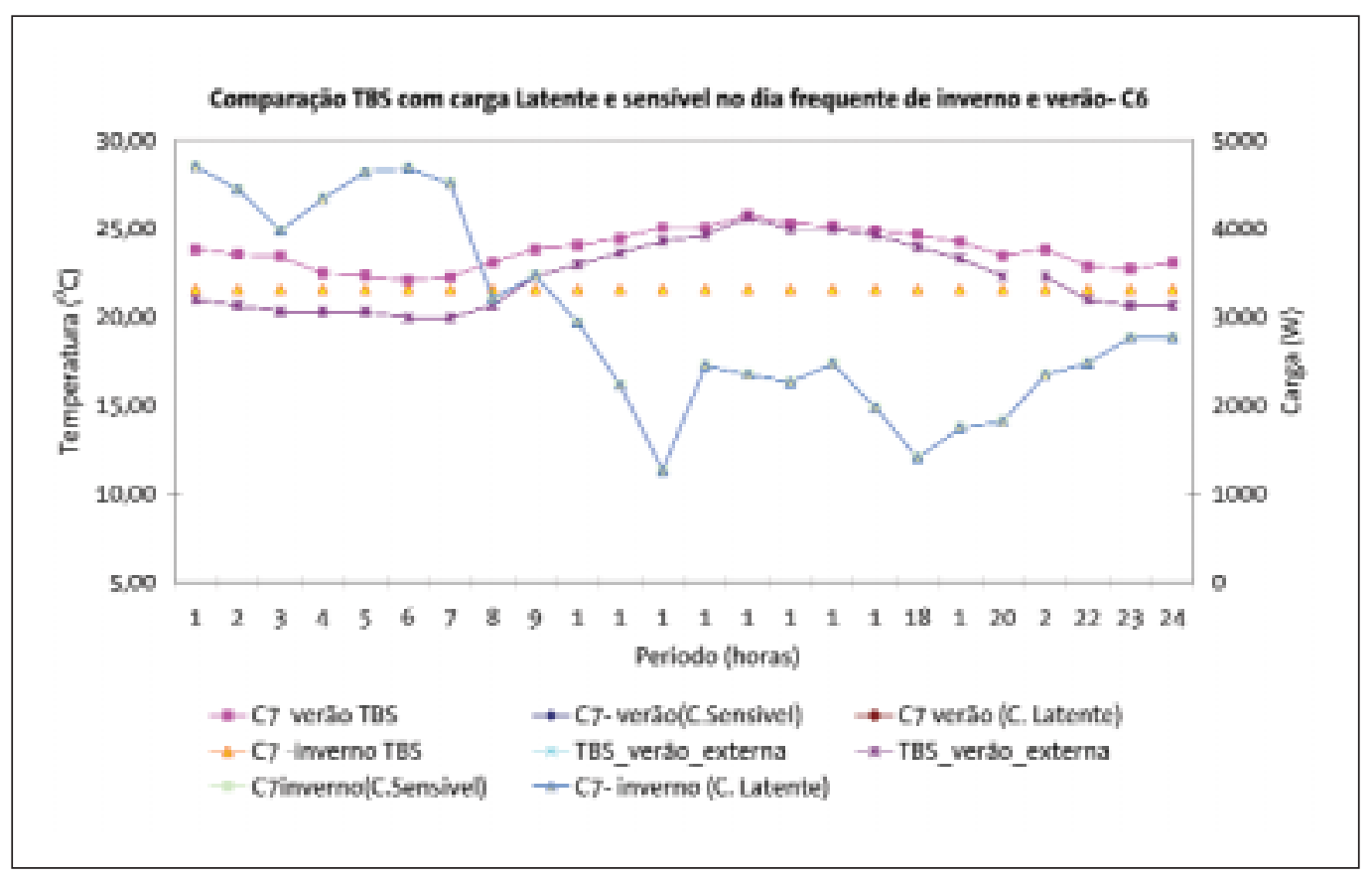

Ilustração 90: TBS interna e externa e carga Latente e Sensível nos dias representativos de inverno e de verão - Cenário7 


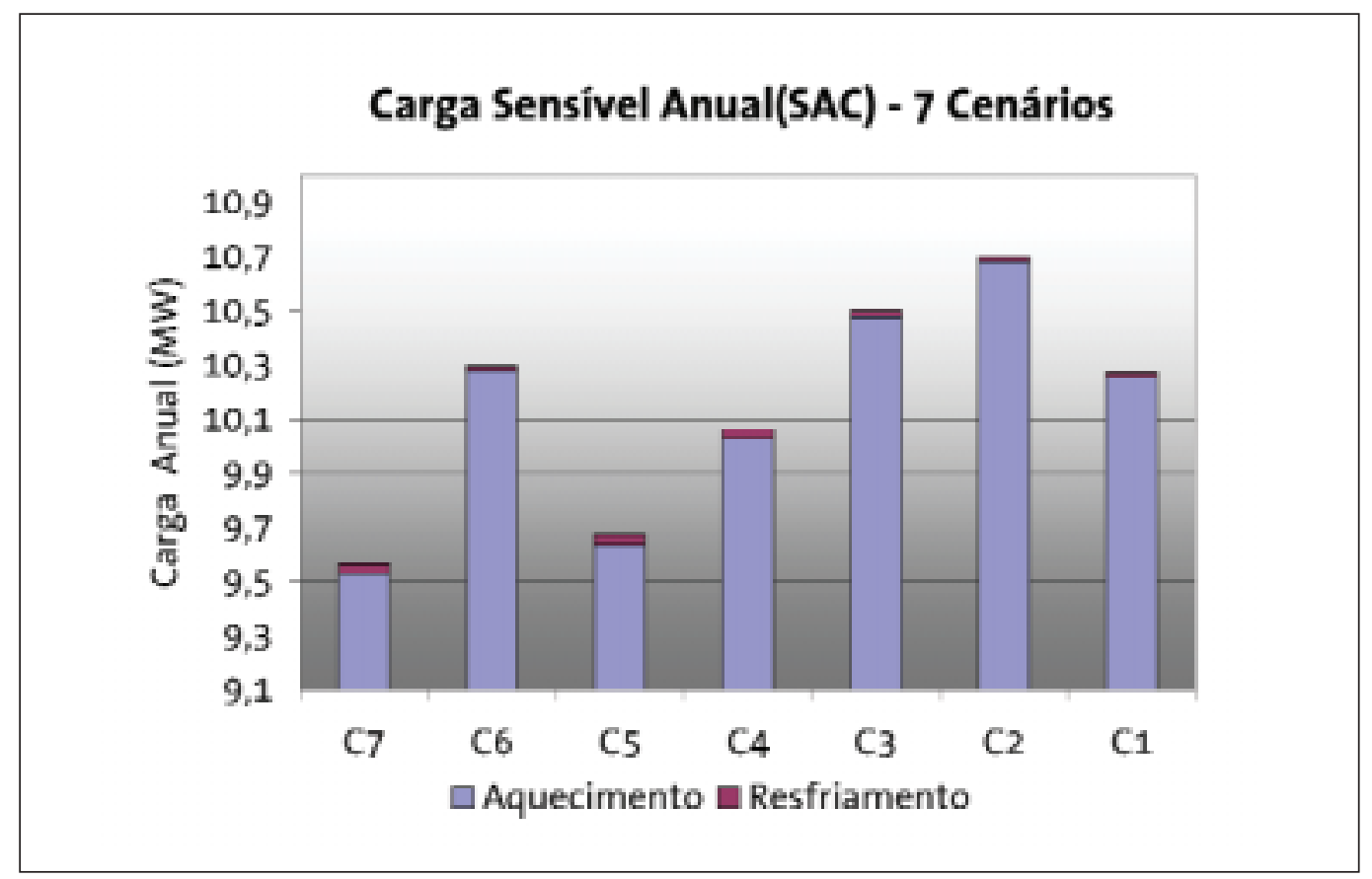

Ilustração 91: Carga sensível (SAC) para todos os Cenários simulados.

longo do ano, verificou-se maior desconforto nos meses mais frios. O Cenário 7 foi o de menor consumo energético, com a menor carga sensivel para aquecimento de todos os anteriores.

Foram constatadas na comparação dos cenários que, devido ao período de ocupação, o maior consumo de energia do SAC ocorre no inverno, para aquecimento. Com isso a interferência dos componentes construtivos, com maior isolamento térmico, reduz a perda de calor no inverno (desejável) . No verão, o atraso térmico faz com que este ganho de calor aconteça no período noturno, quando o ambiente está ocupado e as temperaturas externas são mais baixas.

A menor carga de resfriamento ocorre no Cenário 2, sendo pouco inferior a do Cenário o. Porém o maior impacto do consumo provém de aquecimento, as características do Cenário 7, com mais isolamento, ventilação mais controlada, sem cortina interna favorece o melhor desempenho anual.

Constatou-se, com estas simulações computacionais, que o edifício do modelo-base favoreceu também os resultados obtidos, já que possui características construtivas que determinaram uma inércia alta e, com isso, as respostas da edificação às variáveis externas são lentas.

As fontes internas de geração de calor (pessoas, iluminação e equipamentos) são pequenas e não prejudicam o aproveitamento da ventilação natural no verão, mas não favorecem o aumento da temperatura interna no inverno, fator desejável. 


\section{Propostas de projeto para Hotel Econômico em São Paulo}

A proposta de projeto para Hotel Econômico leva em conta todos os elementos da pesquisa apresentados anteriormente, a base teórica, bem como a base empírica: os resultados da avaliação do Estudo de Caso (Apêndice A) e a análise dos resultados das simulações computacionais (capítulo 5). O estudo foi feito para a cidade de São Paulo, cuja avaliação do diagnóstico climático consta na seção 4.3.

Considerando que o objeto de estudo é a qualidade ambiental dos apartamentos, das unidades habitacionais (UH) dos Hotéis Econômicos, a proposta de projeto contempla a planta do pavimento tipo, e as unidades habitacionais (UH). Ela consistiu em três partes:

$1^{\text {a }}$ parte: Avaliação de arranjos de plantas do pavimento tipo;

$\mathbf{2}^{\mathrm{a}}$ parte: Estudo das fachadas;

$3^{\text {a }}$ parte: Proposta para a unidade habitacional.

Esta proposta não consiste em todas as etapas do processo de projeto, apresentadas na seção 4.1, já que a intenção é propor recomendações de projeto. Dessa forma, não foi definido um terreno para abrigar esse projeto e nem mesmo o programa completo de um Hotel Econômico. Os elementos considerados no projeto foram:

- Planta do pavimento tipo com 16 a $20 \mathrm{UH}$;

- Entorno sem obstrução, com as condições de insolação e ventilação natural sem interferências;

- Terreno hipotético, adimensional;

- Condições de ocupação iguais ao modelo base utilizado nas simulações. 
Como subsídios para o projeto, foram considerados os resultados obtidos nas simulações. Nesta etapa do trabalho, verificou-se que os ganhos de calor pelas fontes internas (pessoas, equipamentos e iluminação) são pequenos e não interferem nas condições de conforto e desconforto dos apartamentos. No inverno, não favorecem o aumento da temperatura interna, situação desejável de acordo com o clima porém, no verão, não prejudicam as condições naturais, auxiliando no aproveitamento da ventilação natural.

A temperatura radiante média (TRM) calculada do modelo empírico, no Apêndice A, mostrou-se muito próxima da temperatura do ar (TBS), demonstrando que não há interferência significativa das superfícies internas nos ganhos de calor interno. Na avaliação do modelo empírico, com as janelas fechadas, constatou-se que a variação da temperatura interna foi muito pequena, e dentro dos limites de conforto térmico do modelo adaptativo da ASHRAE 55 (2004).

O edifício do estudo de caso, que determinou o modelo do caso base, favoreceu também os resultados obtidos, já que possui características construtivas que determinaram uma inércia alta e, com isso, as respostas da edificação às variáveis externas são lentas.

\subsection{Premissas para o projeto}

O Hotel Econômico, como foi constatado anteriormente, caracteriza-se por um Edifício em que a UH é o objeto de maior relevância para o usuário-hóspede. Trata-se do ambiente ocupado por mais tempo pelos usuários, predominantemente no período noturno, além de ser o maior responsável pelos gastos com energia, água e luz do edifício.

O fato da ocupação dos hotéis ocorrer no período noturno, quando as temperaturas externas, tanto no verão quanto no inverno, são mais baixas, auxilia para que se obtenham condições mais favoráveis no verão, quando as temperaturas mais baixas favorecem a obtenção de conforto térmico, ao contrário do inverno. Dessa forma, a abertura das janelas no período noturno favorece a entrada do ar a temperaturas menores do que as internas, e desfavoráveis no inverno, quando as temperaturas no mesmo período são muito inferiores as temperaturas de conforto.

Nas simulações computacionais, utilizando o arquivo climático de De Benedetto (2006), constatou-se que o maior consumo de energia do SAC ocorre 
no inverno, com o aquecimento. Por esse motivo, verificou-se, por meio dos resultados obtidos do Cenário 7, que a interferência dos componentes construtivos, com maior isolamento da parede externa, favoreceu o inverno, quando ocorreu uma menor perda de carga térmica pelos componentes em relação aos outros cenários simulados.

Considerando os aspectos arquitetônicos dos Hotéis Econômicos, verificou-se que a qualidade espacial e a mbiental da UH não é boa. As UH podem ser mais agradáveis, mantendo a simplicidade que um Hotel Econômico determina.

Por esse motivo, esta etapa da pesquisa fundamentou-se em dois aspectos básicos: no dimensionamento da UH, que consta na seção 3.2.2 reavaliado para abrigar as necessidades e os equipamentos mais atuais (como TV de plasma, e camas extras embutidas no mobiliário), e na busca por uma proporção do ambiente, para melhorar a sensação de bem estar do usuário-hóspede, quando abrigado nesse ambiente.

A pesquisa então buscou referências na harmonia das proporções humanas, tal como referida por Vitruvius, arquiteto e escritor romano do século I (DOCZI, 1990), o qual constata que existe uma harmonia perfeita entre todas as partes do corpo humano.

O matemático alemão Zeizing formulou em 1855 o princípio que “(...)para que um todo dividido em duas partes desiguais pareça belo, do ponto de vista da forma, deve apresentar a parte menor e a maior a mesma relação que entre esta e o todo". Surgio daí o número de ouro, que traduz uma operação harmoniosa para os nossos sentidos. No Renascimento italiano, Leonardo da Vinci ilustrou sua versão da idéia da proporcionalidade humana na famosa imagem do Homem Vitruviano (IL. 92), e essa mesma relação harmônica foi confirmada nas proporções da seção áurea (denominada por Da Vinci como a divisão de um segmento segundo a proporção áurea).

Entre 1942 e 1948 o arquiteto Suiço Le Corbusier, que ficou conhecido por seus projetos na França, desenvolveu um sistema de medição que ficou conhecido por "Modulor". Baseado na razão áurea, e utilizando as dimensões médias humanas, o "Modulor" é uma seqüência de medidas que Le Corbusier usou para encontrar harmonia nas suas composições arquitetonicas.

A proporção áurea pode ser constatada nas formas animais, tais como borboletas e caracóis, nas construções dos templos gregos e até mesmo na dimensão dos papéis moeda, cartões de crédito e cheques.

Com relação ao projeto tradicional de Hotel Econômico, com corredor central e UH com orientações opostas, constatou-se, na sua arquitetura e na distri- 


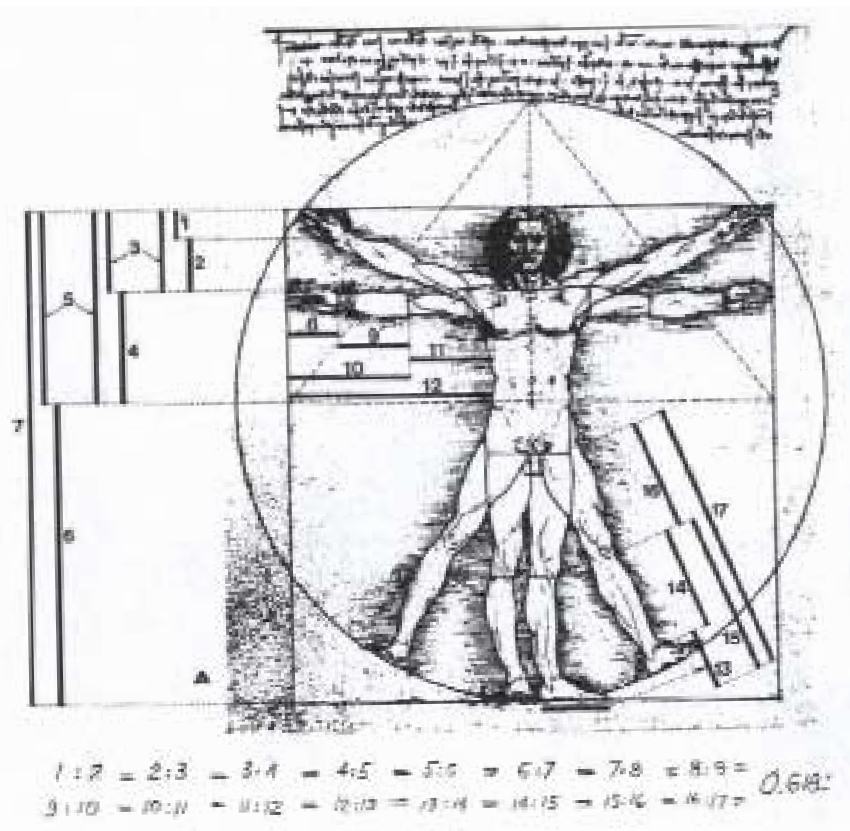

Ilustração 92: Interpretação de Leonardo da Vinci do Homem de Vitruvius, com as indicações das proporções áureas

Fonte: DOCZI, 1990.

\section{Aspectos positivos}

Pavimento tipo compacto (planta retangular) compatível para terrenos estreitos

Forro do banheiro esconde a tubulação do SAC e hidráulica

Shafts de Hidráulica com acesso pelo corredor da circulação interna

Menor área ocupada pela circulação horizontal-corredores menores

\section{Aspectos negativos}

Não possibilita o aproveitamento da ventilação cruzada nas UH

Banheiro sem ventilação natural - manutenção mais freqüente

Shafts ocupam espaço em área nobre da planta do tipo

Corredores de circulação monótonos luz natural restrita as extremidades

Ilustração 93: Comparação entre aspectos positivos e negativos da planta padrão de um Hotel Econômico

buição dos espaços internos, aspectos do edifício que detêm pontos positivos e negativos, como indicado na IL. 93.

Partindo dessa avaliação inicial do projeto padrão, a pesquisa partiu então para o levantamento das estratégias de projeto que poderiam também auxiliar em propostas de projeto mais harmoniosos e com qualidade ambiental. 


\subsubsection{Estratégias de projeto}

O diagnóstico climático, considerando o período de ocupação de um Hotel Econômico, determinou a adoção de duas estratégias ao longo de todo ano: nos meses mais quentes do ano, a ventilação, e nos meses mais frios do ano, o uso de massa térmica de aquecimento.

Como foi constatado na pesquisa, apesar do diagnóstico climático não determinar a necessidade dessa estratégia para a obtenção de conforto, as características dos Hotéis Econômicos das redes internacionais determina a a necessidade do projeto considerar o uso do SAC. Por esse motivo, a proposta deve contemplar a integração do SAC com as estratégias passivas.

Como premissa inicial de projeto, considerou-se o melhor aproveitamento da ventilação, seja ela natural ou mecânica. Isso implicaria um SAC com capacidades menores, já que o sistema atenderia apenas em situações extremas de desconforto ou nos casos de usuários 'viciados' em ar condicionado.

A ventilação deve ser estudada para cada período do ano e também integrada com outras estratégias de projeto, cuja descrição consta a seguir.

\section{Ventilação nos meses mais quentes do ano}

Contatado que a carga térmica tem pouca interferência nos ganhos de calor internos, e sabendo-se que o período de ocupação é predominantemente noturno, deve-se avaliar o posicionamento e dimensionamento das aberturas de entrada e saída do ar. O seu dimensionamento adequado pressupõe favorecer a circulação do ar no interior do ambiente, de acordo com os interesses, e controle das aberturas feito pelos usuários-hóspedes.

O posicionamento das aberturas no sentido perpendicular ao vento predominante favorece a entrada o ar numa zona de alta pressão e a saída do ar na face oposta, numa zona de baixa pressão, em uma fachada protegida da incidência do vento.

As análises apresentadas por Bittencourt e Cândido (2005), apresentadas na seção 4.6.1, ilustram o quanto a forma do edifício pode favorecer ou não o aproveitamento das variações de pressão em torno do mesmo.

\section{Ventilação nos meses mais frios do ano}

Neste período, quando a estratégia determinante é o uso da massa térmica de aquecimento, a ventilação deve restringir-se ao mínimo, tanto para evitar a perda do calor acumulado quanto para que haja uma ventilação higiênica: o volume de ar do ambiente deve ser renovado segundo as recomendações da ANVISA (2003), mantendo a qualidade do ar e a salubridade do ambiente. 


\section{Ventilação por efeito chaminé}

A ventilação por efeito chaminé aproveita a diferença de pressão do ar mais quente (que tende a subir) com o mais frio, estabelecendo assim um fluxo de vento no sentido ascendente.

Essa ventilação depende da diferença de altura das aberturas inferiores com as aberturas superiores, da inércia do ambiente (calculada de acordo com o peso das superfícies opacas), e a diferença de temperatura externa e interna.

O projeto do Hotel Burj al Arab, em Dubai, apresentado na seção 4.6.1, indica a presença de átrios internos sem climatização artificial, e se aproveita dessa estratégia para manter os hóspedes em conforto num ambiente amplo, que costuma ser os saguões de entrada, lobby e recepção, com pé direito livre até a cobertura, integrado aos corredores internos da circulação.

\section{Chaminé Solar}

Entende-se como chaminé solar, uma estratégia mista: de aquecimento solar passivo com o efeito chaminé. A chaminé solar tira partido do aquecimento do sol, que pode ocorrer tanto no topo de um átrio quanto numa superfície lateral (desde que isolada termicamente do ar do átrio), para aumentar a diferença de temperatura entre os andares mais inferiores, e os superiores, e com isso aprimorar a ventilação por efeito chaminé.

A adoção dessa estratégia deve ser feita, considerando-se a compartimentação dos ambientes, pois contatou-se em pesquisas anteriores, por meio de análises de custo-benefício e pay-back, que os custos adicionais com os dutos da saída do ar não viabilizam esta solução em qualquer projeto, e divisão interna.

\section{Massa térmica de Aquecimento}

Esta estratégia depende das características construtivas e da composição dos materiais que determinam a inércia térmica da envoltória, que atrasa o ganho de calor. Utiliza deste ganho para auxiliar no aquecimento, principalmente nos períodos mais frios do ano. 


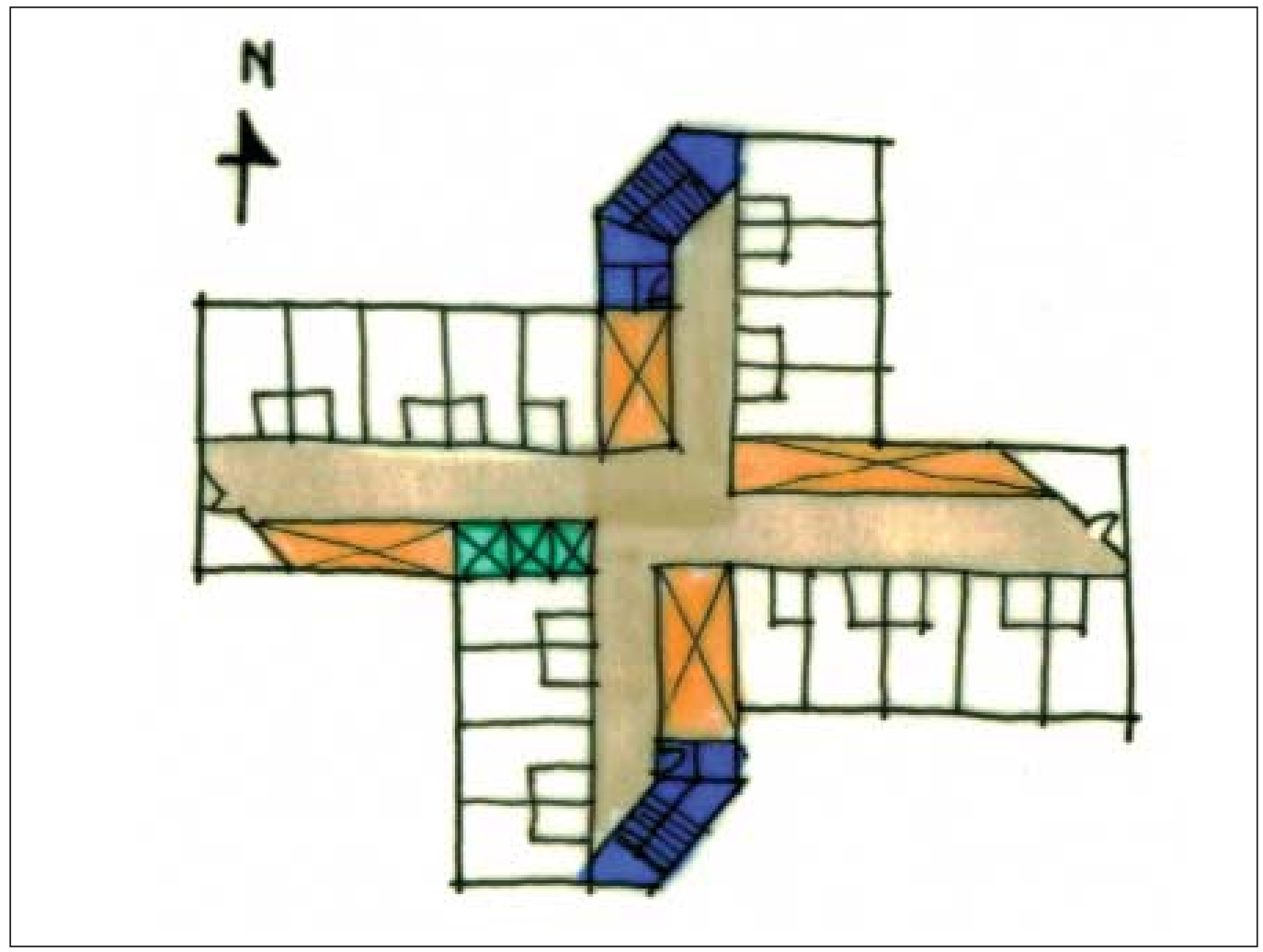

Ilustração 94: Planta do pavimento-tipo - Opção A.

\subsection{Avaliação dos arranjos do pavimento tipo}

As características da planta tipo do projeto padrão de um Hotel Econômico, com a distribuição das UH frente-a-frente, é um fator determinante que dificulta o aproveitamento da ventilação natural. Baseando-se neste aspecto, a proposta consistiu em estudar novos arranjos na disposição das UH ao longo do pavimento tipo.

Foram propostos então dois arranjos:

- na opção A, IL. 94 os corredores internos possuem pequenos átrios que permitem a saída do ar do interior da UH pelo efeito chaminé, conforme indicado em corte esquemático na IL. 95.

- na opção B, apresentada na IL. 96, a planta-tipo segue também as proporções áureas, buscando contudo manter a quantidade de UH dentro do que foi proposto previamente, uma parte das UH ficando em um bloco retangular, dispostas frente a frente, como no padrão original da planta dos Hotéis Econômicos.

Por esse motivo, na concepção das UH, também foram considerados dois projetos, apresentados posteriormente. 


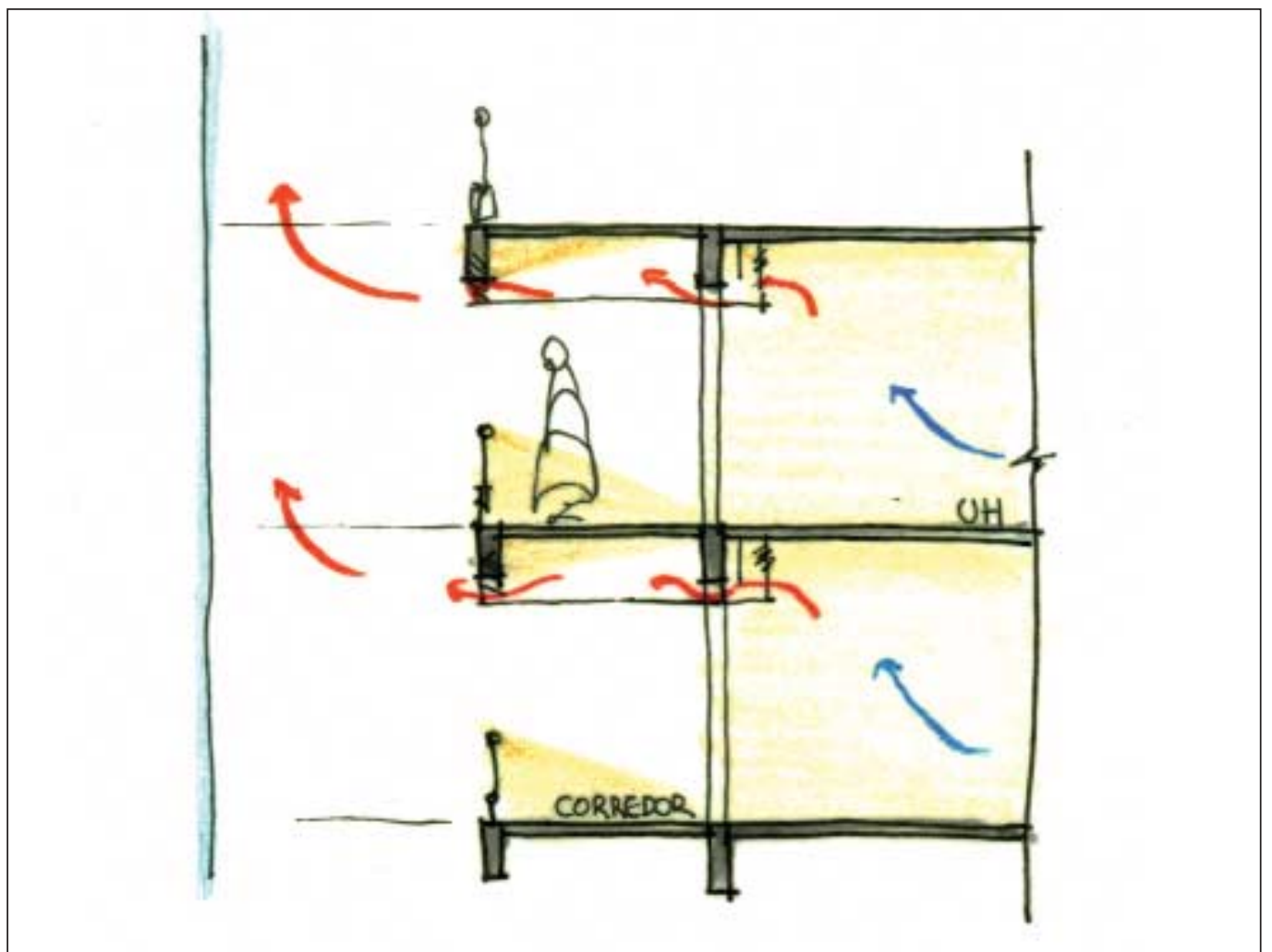

Ilustração 95: Corte esquemático - Opção A.

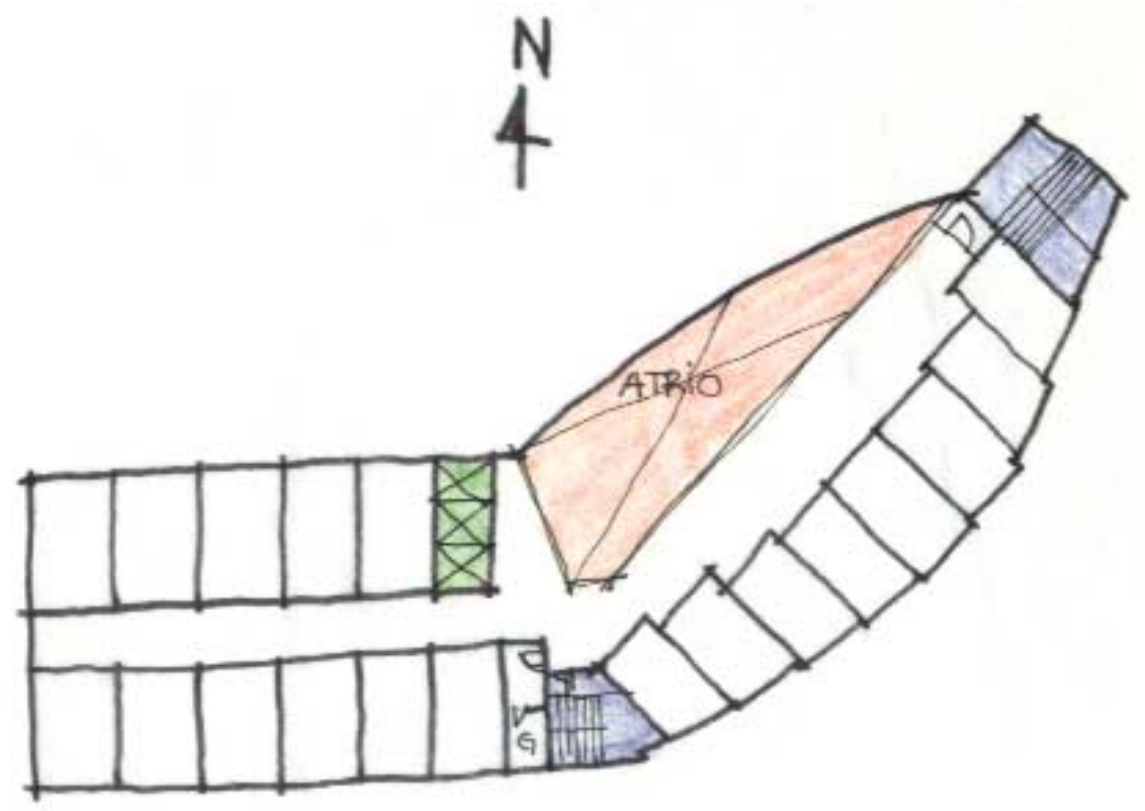

Ilustração 96: Planta do pavimento-tipo - Opção B. 


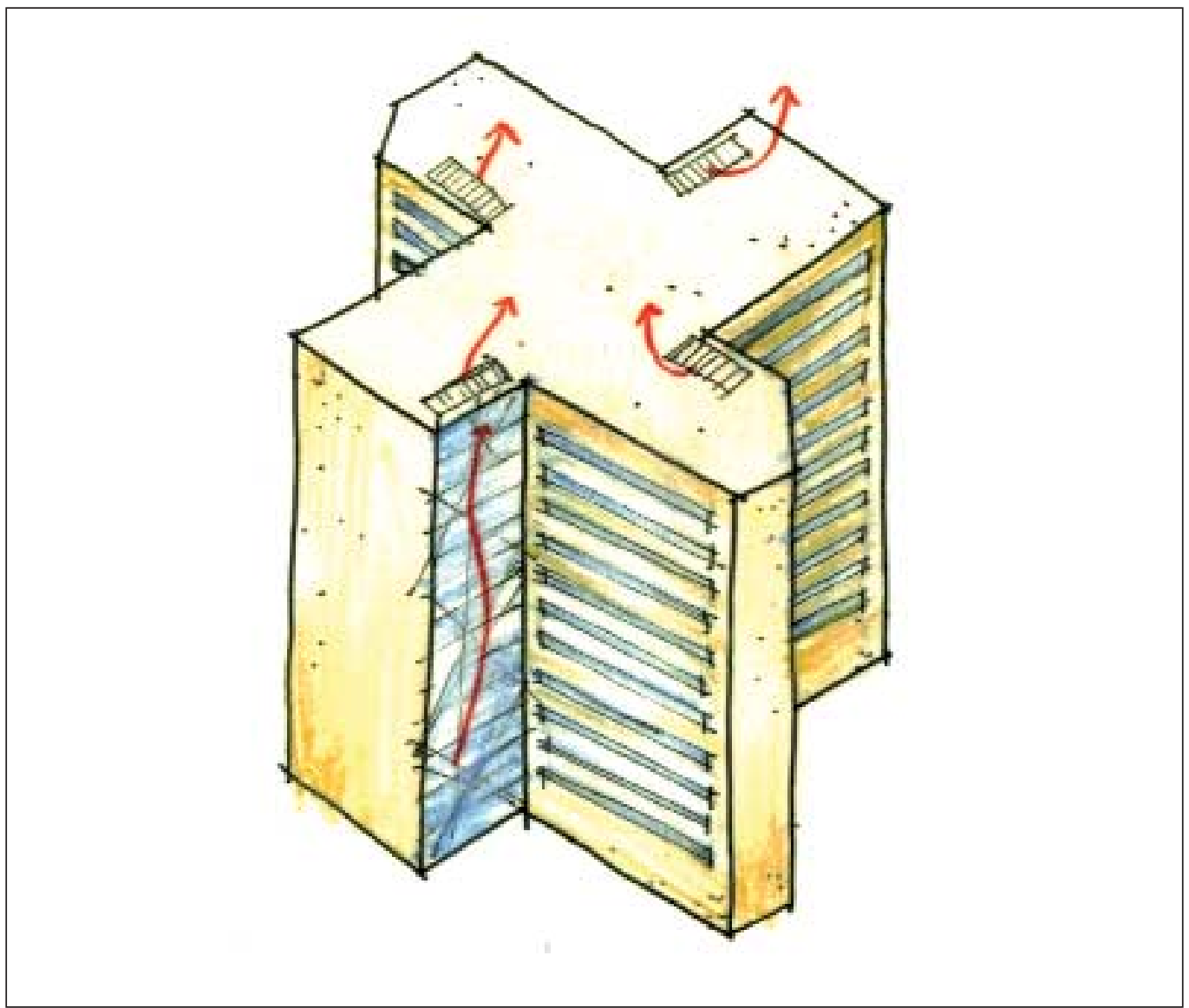

Ilustração 97: Perspectiva das Fachadas- Opção A.

\subsection{Estudos das fachadas}

Para as duas propostas apresentadas anteriormente, os estudos das fachadas, opção A e B, com a indicação em vermelho da saída do ar quente pelo átrio, estão apresentados nas IL. 97 e IL 98, respectivamente. Não foi dimensionado nenhum brise externo em nenhum dos casos, pois as condições do entorno, assim como a orientação, interferem no projeto e dimensionamento dos brises. Além disso, nos vários Cenários simulados no modelo computacional, não foram considerados brises externos, e os resultados satisfatórios foram obtidos considerando as variações dos vidros, cortinas internas e da taxa de ventilação do ambiente.

Nos estudos propostos para a Opção B, está representado na cobertura um elemento inclinado que protege a saída do ar, ao mesmo tempo podendo abrigar placas solares para o aquecimento da água dos banheiros. Dependendo da composição e das características do material, este pode também servir como uma chaminé solar que auxilia na saída do ar do átrio pelo efeito chaminé. 

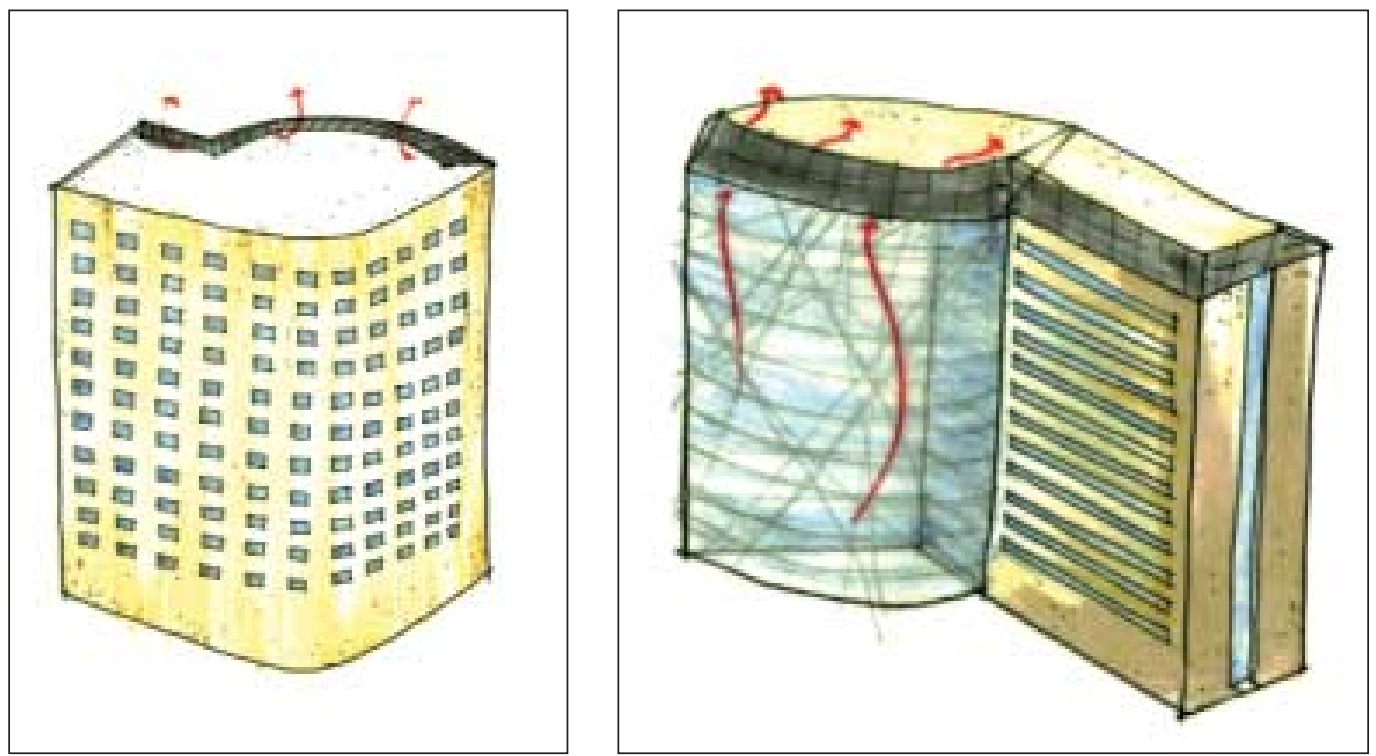

Ilustração 98: Perspectiva das Fachadas- Opção B.

\subsection{Propostas para a Unidade Habitacional}

A proposta da unidade habitacional (UH) considerou as recomendações para os Hotéis Econômicos: compactos o suficiente para manterem o hóspede confortável no espaço, com o aconchego de um ambiente intimo e que atenda também suas necessidades básicas de higiene pessoal, descanso e trabalho.

Considerando a qualidade espacial da UH, as dimensões seguiram a relação áurea, buscando estabelecer um equilíbrio harmônico no ambiente interno.

O projeto considerou a necessidade de alteração, tanto para UH com desenho universal, ou seja, adaptadas para deficientes, quando para o acréscimo de cama extra. Este último caso refere-se ao modelo das redes internacionais, em que algumas unidades já possuem mobiliário adaptado para a cama extra, sem alterar o padrão original da UH do hotel.

A opção 1, na IL.99, baseia-se na planta padrão da UH, buscando adequar seu dimensionamento e distribuição interna de forma a minimizar os aspectos negativos e aproveitar os aspectos positivos apresentados na IL. 93. Nesta proposta, o armário e frigobar foram posicionados ao lado da parede do banheiro (IL. 100), mantendo, na parte interior da unidade as camas, a TV (de plasma, suspensa na parede) e o espaço para a cama extra, embutida no mobiliário da parede.

A opção 2 propõe um rearranjo da UH, na IL. 101, dispondo o WC voltado para a fachada externa, eliminando a necessidade de ventilação mecânica, porém criando um shaft externo à fachada, com acesso dificultado para a manutenção. 


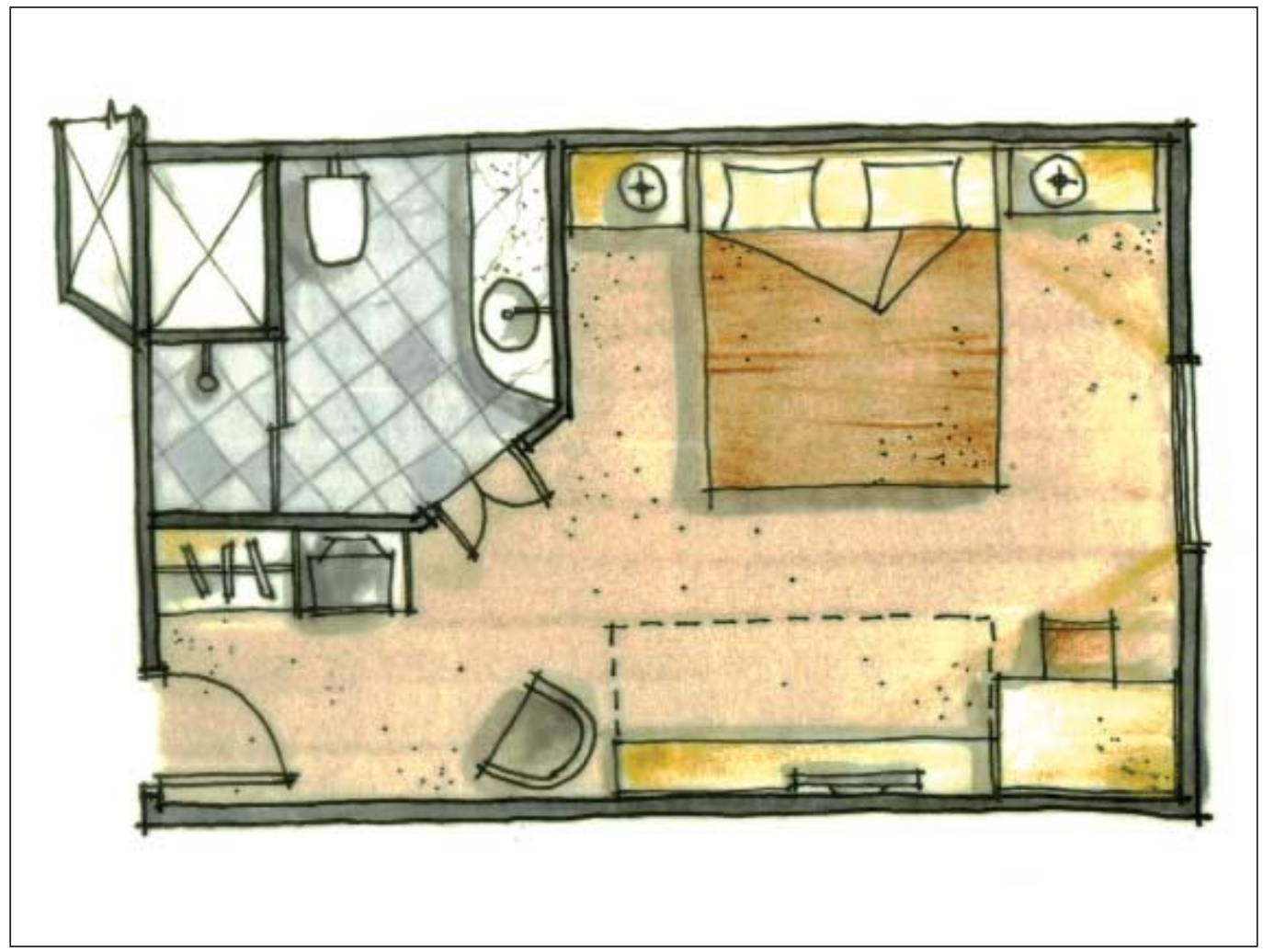

Ilustração 99: Planta da UH - Opção 1.

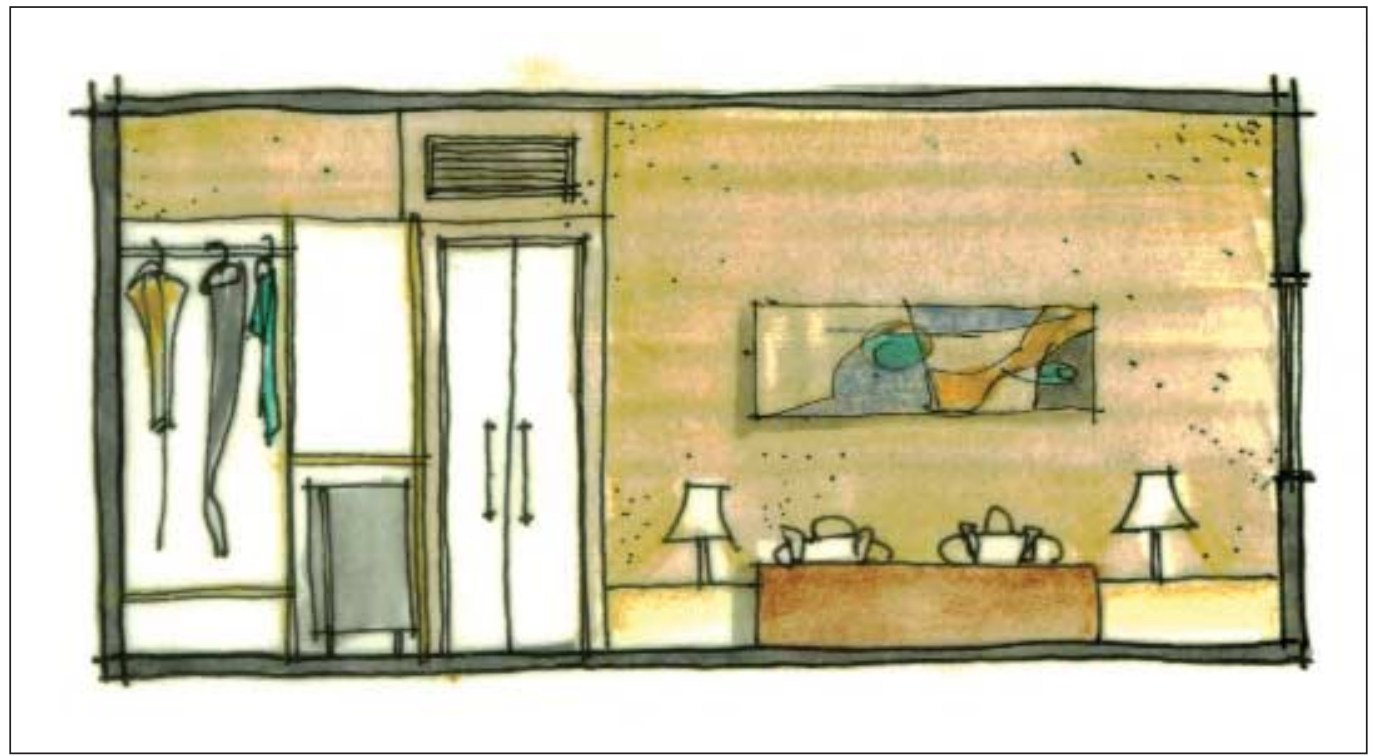

Ilustração 100: Vista da UH - Opção 1. 


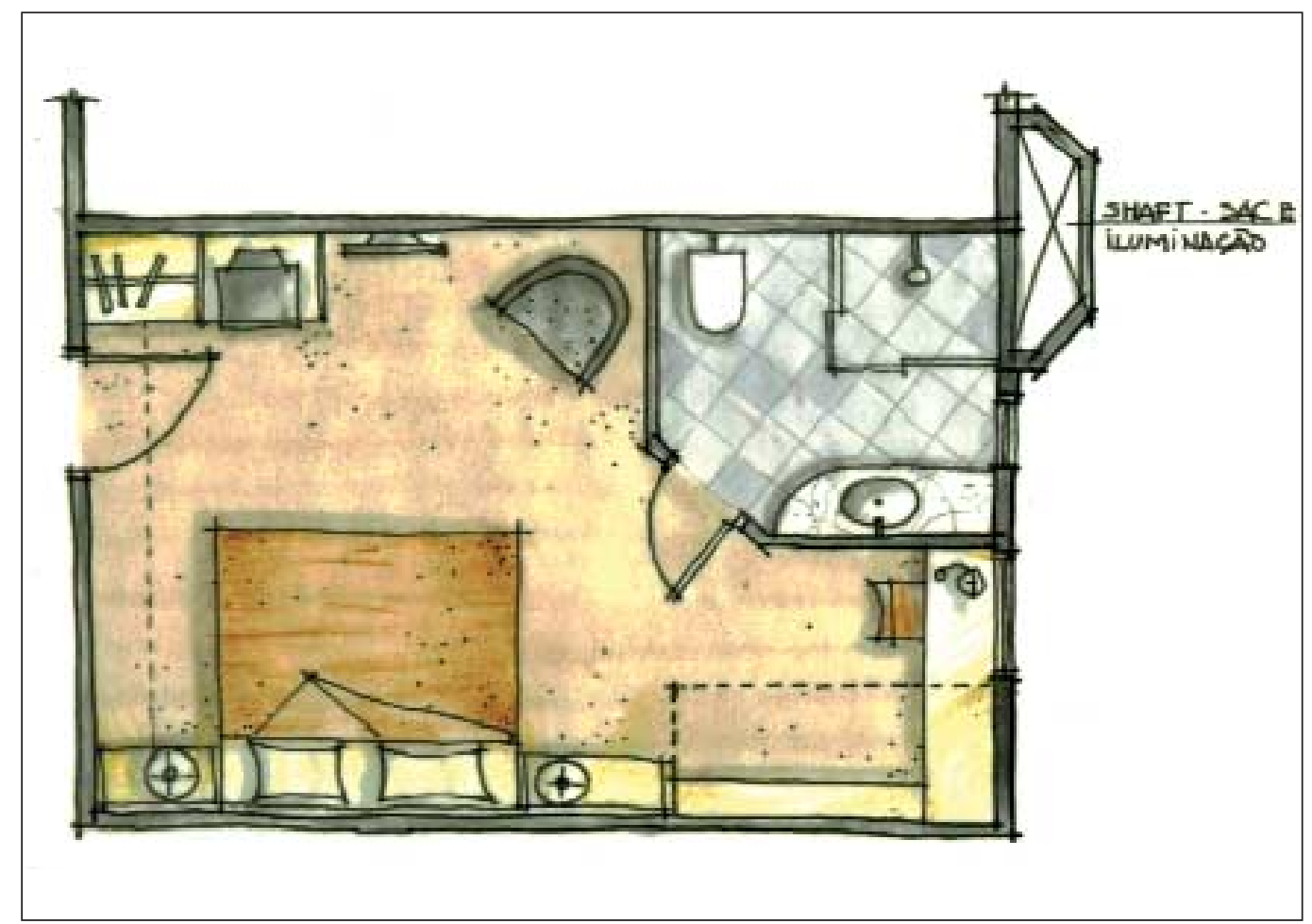

Ilustração 101: Planta da UH - Opção 2.

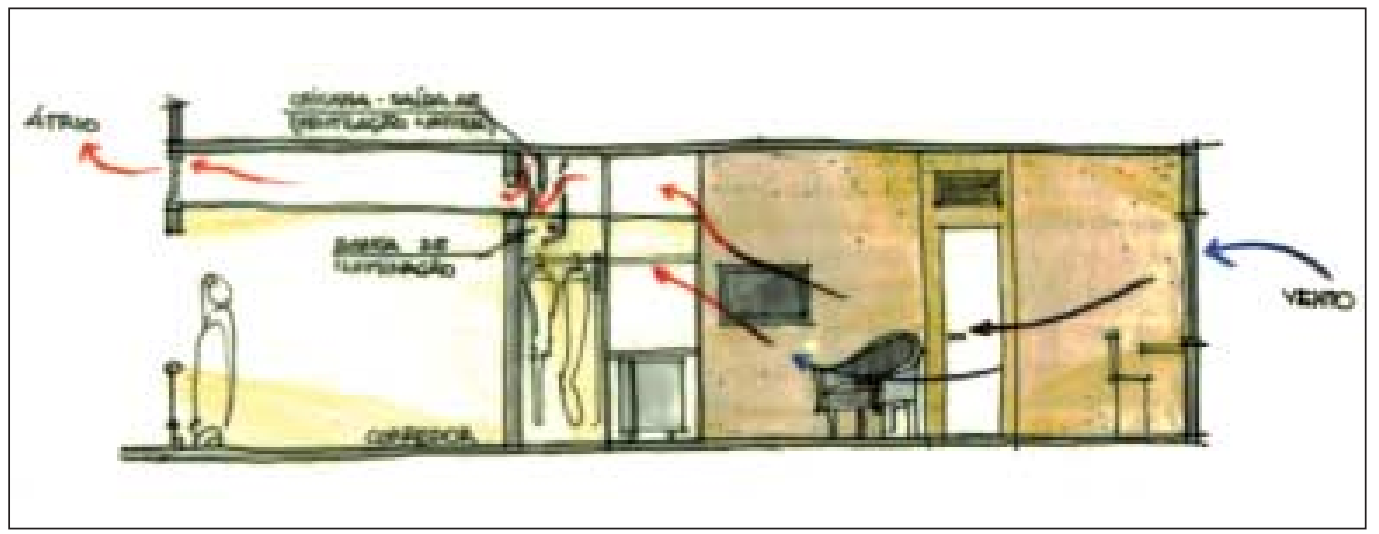

Ilustração 102: Corte da UH - Opção 2.

Esta proposta elimina também o hall interno, que pode ser desfavorável por não estabelecer uma separação um pouco maior do corredor de circulação com o ambiente privativo do quarto. Trata-se também do aspecto psicológico do usuário, que pode se sentir "ameaçado" por estar com sua cama tão próxima à saída do corredor.

Merece atenção a saída do ar quente (representada na IL. 102), através de chicane (com isolamento acústico, para não prejudicar a privacidade da UH) na parte superior oposta a fachada. $\mathrm{O}$ ar fresco que penetra pela fachada, atravessa 


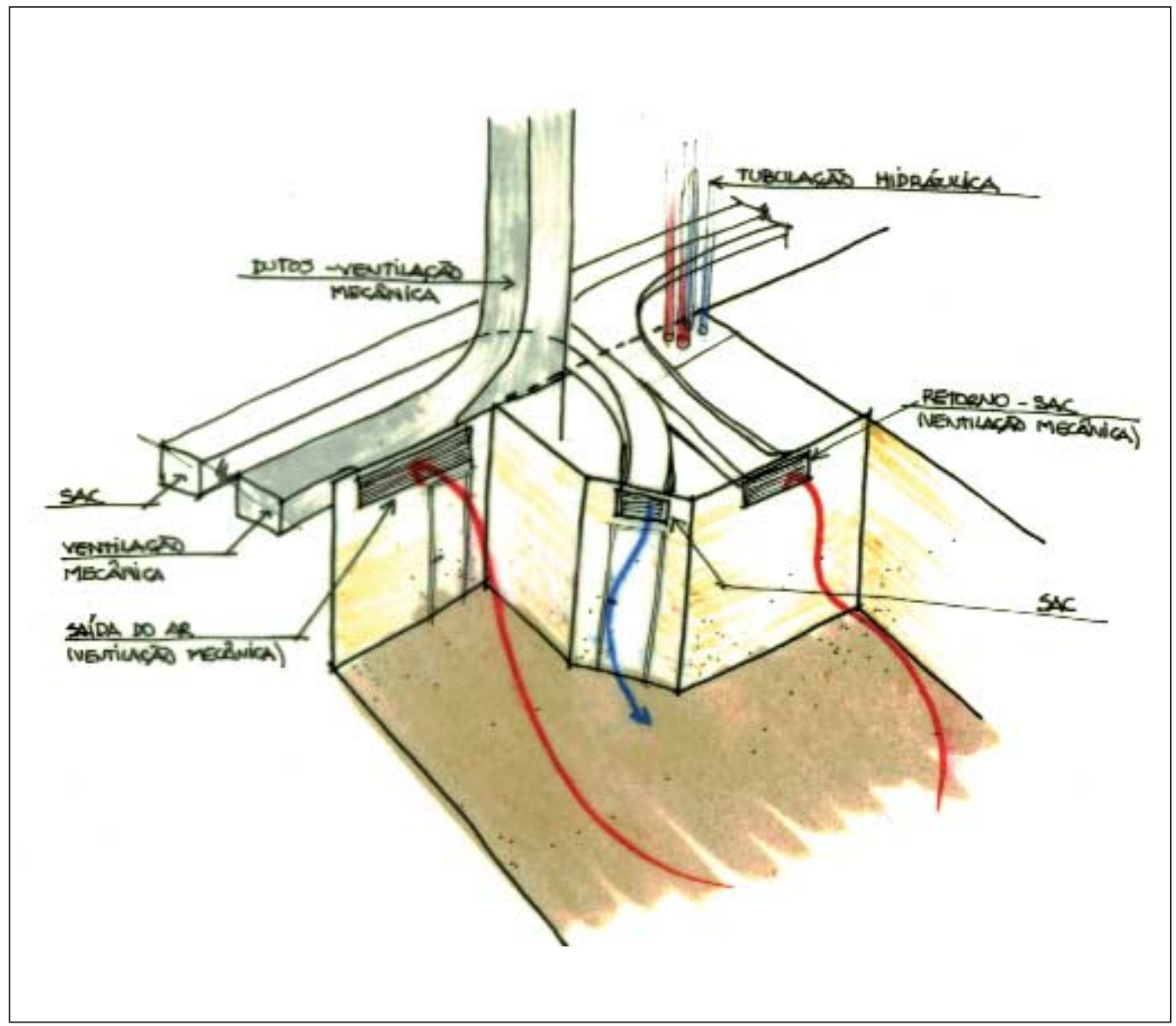

Ilustração 103: Perspectiva de sistema de ventilação com SAC.

a UH e será eliminado na grelha alta, ao lado do corredor através dos dutos. Esse ar se movimentará para o átrio, com ou sem o auxílio de ventiladores (isso deve ser devidamente dimensionado para manter o funcionamento adequado).

\subsubsection{Detalhes arquitetônicos}

Considerando as propostas de projeto e a necessidade de aproveitar a ventilação natural e integrar o projeto de arquitetura com o projeto do SAC, foram estudados dois detalhes que podem ser incluídos na concepção das UH, conforme o projeto do hotel.

No primeiro detalhe, na IL. 103, partindo do padrão original da planta da UH, foi incluída uma grelha na parede oposta da fachada, para estabelecer uma ventilação cruzada com os dutos embutidos no forro do corredor.

No segundo detalhe, buscando o aprimoramento da ventilação natural, foi estudado um sistema que pode ser integrado à parte inferior das janelas, como 


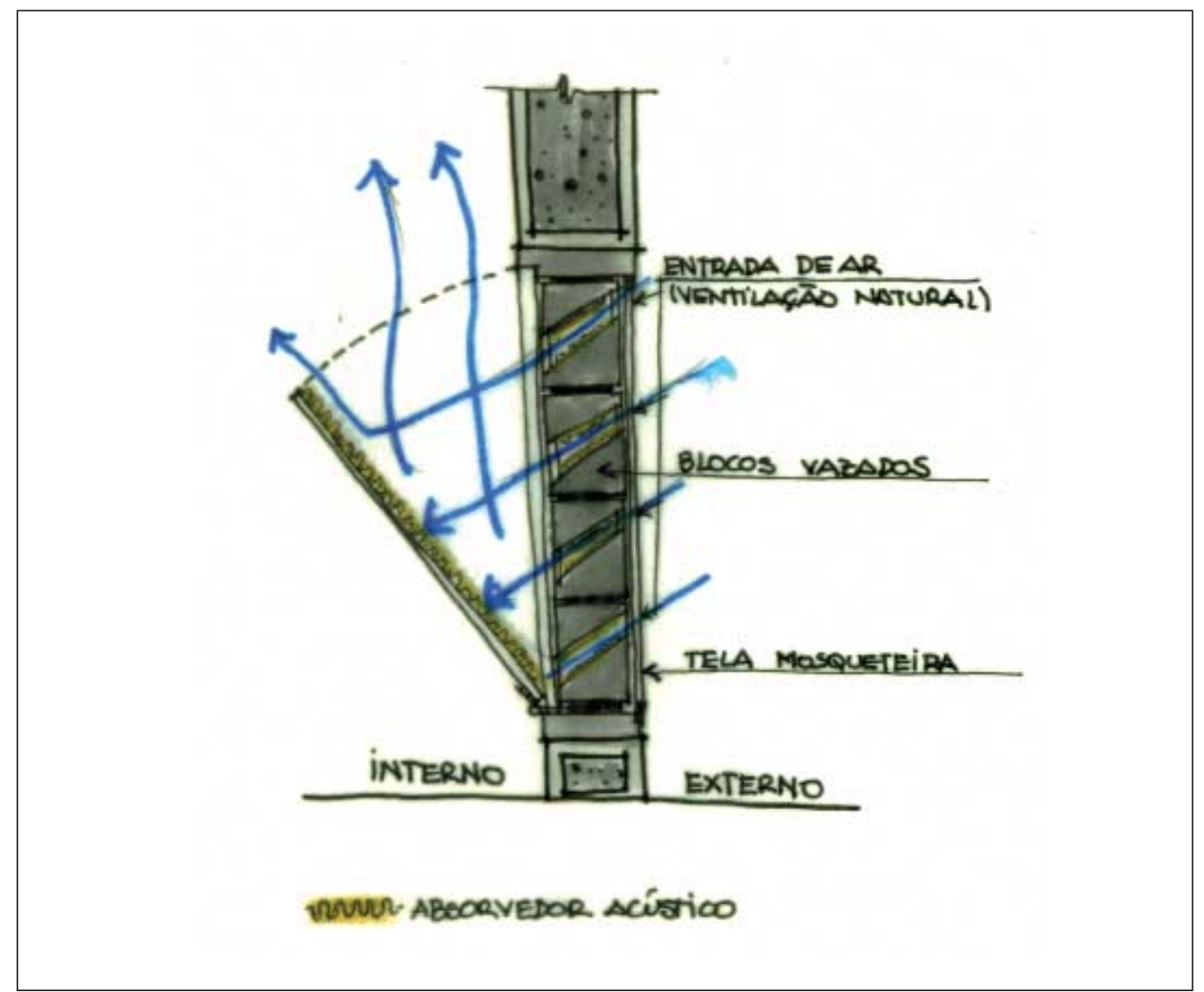

Ilustração 104: Corte esquemático de sistema para melhorar o aproveitamento da ventilação natural.

na IL. 104. Trata-se de blocos vazados que permitem a entrada do ar externo, protegidos por uma tela mosqueteira, e com absorvedores acústicos (se necessário, dependendo das condições do entorno) e com um fechamento regulável na parte interna, também dotado de absorvedores acústicos, se necessário.

A regulagem de abertura fica a critério do hóspede, destacando que a forma de abertura deste sistema favorece que a circulação do ar externo não incida diretamente no usuário, causando o efeito indesejável de corrente de vento diretamente sobre ele.

O estudo dos materiais, a viabilidade das soluções propostas, tanto econômica quanto construtiva, além da necessidade de análise das alternativas de projeto para verificar se estas atendem às condições de conforto dos usuários dependem do terreno, do entorno e do programa completo do hotel, não fazendo parte da proposta desta pesquisa. 


\section{Considerações finais}

A escassez energética e o conseqüente aumento de preços e tarifas de energia têm sido, cada vez mais, assunto prioritário nas discussões mundiais, como foi explicitado no início desta pesquisa. Tal situação acentuou-se ainda mais com a intensificação do processo de aquecimento global e os conseqüentes riscos acarretados pelas mudanças climáticas por ele desencadeadas. Como resultado disso, o Painel Intergovernamental de Mudanças Climáticas, o IPCC ${ }^{26}$ (WTTC, 2007), enumerou diversas medidas, com a finalidade de buscar reverter essa situação, fazendo recomendações, tanto no que tange à redução das emissões de carbono na atmosfera, quanto no sentido de reduzir o consumo energético mundial. Dentre essas medidas, o destaque maior foi dado para as necessidades de redução no consumo energético dos edifícios.

Nos países em que a energia elétrica é proveniente de fontes não renováveis, tais como usinas nucleares ou termo elétricas, o custo da energia produzida tende a ser mais elevado, se comparados ao Brasil, cuja base energética é hídrica, ou seja, renovável. Estamos falando da maioria dos países europeus, bem como dos Estados Unidos, ou seja, de países desenvolvidos, cuja economia industrializada resulta num consumo de energia elétrica cada vez maior.

Foi verificado, ao longo desta pesquisa, que esse quadro determinou que vários paises passassem a criar formas e meios para reduzir o consumo de

26. Sigla do inglês: International Painel of Climate Change. 
energia nos diversos setores da economia, buscando, por seu turno, não prejudicar ou mesmo reduzir os prejuízos do desenvolvimento econômico proveniente da produção industrial. As necessidades de reduções foram, então, sendo estudadas e direcionadas a setores da economia tais como residencial e comercial. O setor de edifícios comerciais, comparado aos outros, é o que possui maior potencial de redução, pois tende a não prejudicar o desenvolvimento da economia, diferentemente do setor industrial ou até mesmo de transportes. Com isso, principalmente nos países de economia mais desenvolvida, surgiram normas e leis para obrigar que arquitetos e engenheiros projetem edifícios mais eficientes energeticamente.

Nessa perspectiva, a concepção dos edifícios precisou ser reavaliada, de forma a atender da melhor forma possível a exigência energética. Uma avaliação do programa de necessidades do edifício, das condições climáticas locais e das variáveis arquitetônicas, tais como a forma do edifício, a posição e dimensionamento das aberturas e as características dos materiais de construção, estão entre alguns dos elementos que auxiliam os engenheiros e arquitetos nessa tarefa.

Foi nesse mesmo contexto que esta pesquisa buscou um segmento com representatividade, inserido no de edifícios comerciais e que, ao mesmo tempo, tivesse uma preocupação com o conforto ambiental de seus ocupantes: o setor hoteleiro. Trata-se de uma tipologia de edifícios desafiadora, visto que abriga usuários que pagam pelo conforto oferecido nesse espaço, sendo esses mesmos usuários os elementos fundamentais para o sucesso do empreendimento. Nessas condições, as exigências de conforto dos usuários são tão importantes quanto a necessidade de eficiência energética do edifício.

A pesquisa contextualizou historicamente o setor hoteleiro, enumerou suas características principais e discorreu sobre o surgimento das redes hoteleiras no Brasil. O impacto do surgimento dessas redes no país determinou uma mudança significativa no setor e na profissionalização de serviços oferecidos e tornou-se elemento-chave para que os empreendimentos se mantivessem no mercado. Os novos hotéis das redes, concebidos sob o conceito de eficiência em todos os sentidos (de serviços e de arquitetura) surgiram com serviços de qualidade, preocupados com os certificados ambientais internacionais ou das suas próprias redes, e com uma política de preços competitiva.

Nos últimos anos, verificou-se, no Brasil e em São Paulo, um crescimento ainda maior dos Hotéis Econômicos das redes internacionais. O turismo em crescimento, associado à globalização resultará em uma demanda crescente para hotéis voltados ao turismo. O desafio dessas bandeiras é o de manter a qualidade 
dos serviços em toda rede mundial, com a limitação de custos de construção, operação e serviços (restritos ao mínimo, sem que isso interfira no bem-estar do hóspede). A padronização desses hotéis, que buscam manter a qualidade dos serviços prestados especialmente nas unidades habitacionais (UH), e a possibilidade de replicar as soluções propostas, até para os hotéis de categoria superior, visando a melhoria geral do desempenho dos hotéis da rede, os tornam ainda mais especiais dentro da categoria do setor de edifícios comerciais.

As estratégias das redes internacionais, no Brasil, é a de manter o mesmo padrão oferecido nos outros hotéis do mundo. Verificou-se, no entanto, que já começaram a surgir novos hotéis dessas mesmas redes com uso misto (hotel e escritório), buscando uma diferenciação num mercado tão competitivo. Os hotéis mais tradicionais, como o Maksoud, em São Paulo, criaram outras estratégias para se destacarem: UH com padrões e preços diferenciados num mesmo hotel, soluções essas que ampliam significativamente seu mercado-alvo.

No levantamento de exemplos de hotéis no mundo, presente no capítulo 2 deste trabalho, verificou-se inicialmente a compacticidade dos hotéis e, principalmente, a interação do projeto de arquitetura com as necessidades do uso a que o hotel se destina. Fala-se aqui do mercado principal do hotel, seja para abrigo de hóspedes para esquiar, seja para descanso em "espaço único com percepção sensorial", seja num espaço de luxo, destinado a executivos, como no caso da Torre Skiodome, no Japão.

A concepção arquitetônica, nestes exemplos, levou em conta também os aspectos da eficiência energética, sem sobreposição sobre a qualidade e o conforto. Isso pode ser constatado com vários exemplos:

- No Hotel Cube, em Savognin, e em sua preocupação com a circulação vertical dos hóspedes com o equipamento de esqui, que considera a ausência de elevadores, e também na UH, projetada com hall interno para abrigo dos equipamentos volumosos, mantendo a área íntima agradável e visualmente limpa.

- No Hotel Braumaunufaktur, na Alemanha, em que, segundo o próprio arquiteto, a concepção das UH baseou-se na máxima economia de energia elétrica. Todas as UH possuem a mesma orientação, um corredor com iluminação natural e há integração dos pisos de carpete e concreto no corredor (refletindo a preocupação com a acústica e o conforto térmico); a simplicidade do mobiliário integra a cama de casal com as camas extras e com os armários num único mobiliário da UH; o uso do aquecimento pelo piso, que resulta em maior eficiência do SAC e na concepção da fachada com duas camadas para isolar o frio e assim diminuir a necessidade de aquecimento no inverno. 
- No hotel de luxo "Five + Sensotel", na Suiça, projetado para despertar as "experiências sensoriais" do hóspede, segundo palavras da própria arquiteta autora do projeto. Tais experiências seriam facilitadas pelas diferentes cores nas paredes da UH e pela iluminação artificial, que pode simular as variações da iluminação natural ao longo do dia.

- Na Torre Skiodome, um edifício de uso misto no Japão, concebido como escritório (andares inferiores) e hotel (andares superiores), com planta-tipo concebida para cada uso, com diferentes profundidades e distribuição, a qual integra diversos sistemas de eficiência energética, os "ecoshafts" ${ }^{27}$ para ventilação natural, e se utiliza de geração distrital de fornecimento de água quente para atender a demanda do edifício como um todo.

Os Hotéis Econômicos oferecem tarifas reduzidas, em função da igual redução dos custos de instalações e dos serviços restritos ao mínimo, sem prejuízo da qualidade de conforto oferecida ao hóspede. Sua localização deve ser estrategicamente definida, para que seja maximizada a taxa de ocupação (acima de 75\%), bem acima das margens das categorias superiores.

Sabe-se que a gestão operacional das redes de hotéis internacionais funciona, desde as etapas inicias da concepção do projeto do hotel, até o planejamento da gestão da qualidade. Assim, mostrou-se a necessidade do hotel, com objetivo de racionalizar os espaços, equipamentos e serviços, também gerir de forma eficiente o consumo de energia elétrica. Essa intenção possibilita alcançar um melhor desempenho do edifício, sem omitir a função de empreendimento comercial a que essa tipologia de edifício se destina.

Sabe-se que a UH é o principal produto oferecido por um Hotel Econômico e que, segundo Correira (2007), o maior vilão do consumo energético dos edifícios hoteleiros na região Sudeste do Brasil, é o sistema de ar condicionado (SAC), sendo portanto o consumo do SAC das UH um grande responsável por esse resultado. Nesse sentido, a concepção arquitetônica padronizada das redes de hotéis precisa ser reavaliada. $O$ aproveitamento das condições naturais na concepção de um projeto de arquitetura favorece a redução do consumo de energia elétrica e, por isso, na padronização desses projetos, deve ser revisto todo o processo, de modo a tornar esses hotéis econômicos também no sentido financeiro, reduzindo os gastos de manutenção.

27. Dutos de ventilação natural cujo nome foi descrito no projeto da Torre Skiodome. Funcionam como um sistema complementar, independente do ar condicionado, de saída do ar do interior da UH. Utiliza-se também sistema mecânico, para possibilitar o funcionamento em qualquer período do ano que for desejável. 
A seqüência metodológica de projeto de arquitetura, apresentada neste trabalho, destaca a interação das diversas etapas do projeto, a saber: análise do programa arquitetônico, análise da condição de exposição, diagnóstico climático, índices de conforto, seleção dos recursos de projeto, opção de condicionamento, avaliação para as condições naturais, análise das pessoas satisfeitas, estimativa da capacidade do SAC e avaliação do consumo de energia e das características arquitetônicas.

Considerando as necessidades descritas acima, no contexto do Hotel Econômico, a pesquisa verificou alguns elementos que favoreceriam também a eficiência energética nas outras áreas do hotel, com alguns cuidados no projeto de arquitetura, tais como:

\section{Áreas comuns (lobby, recepção.e restaurante)}

Nesses locais, verificou-se a tendência de se projetar um circuito único de iluminação, ao invés de circuitos independentes no balcão de atendimento da recepção, o qual funciona 24 horas do dia. A iluminação de destaque deve ter um circuito independente da iluminação geral do ambiente. As características arquitetônicas da entrada, com amplas áreas envidraçadas, protegidas (do sol e da chuva) para embarque e desembarque dos hóspedes, determinam uma porcentagem de luz difusa, que deve ser considerada no projeto da iluminação artificial dessas áreas. O aproveitamento das condições naturais de iluminação nesses ambientes reduz o consumo com o sistema artificial que, durante o dia, deve complementar o natural.

A existência de portas rotativas ou antecâmaras na entrada reduzem as perdas por infiltração do SAC na entrada ou, caso o projeto não comporte nenhum dos dois casos acima citados, o uso de cortina de ar sobre as aberturas pode minimizar a perda de calor. Destaca-se também que, nesses mesmos locais, mais próximos ao exterior, o set point do SAC deve acompanhar as variações externas, assim da mesma forma como são interpretadas as variações de temperatura pelo modelo adaptativo da ASHRAE 55-2004.

\section{Áreas administrativas}

Deve-se considerar o período de ocupação para determinar o uso de circuitos independentes para as salas que eram ocupadas em periodos diferentes do dia e da noite. Recomenda-se que a iluminação artificial seja integrada com a natural, como apresentado na seção 4.9.1. O uso de luminárias de mesa nas áreas de trabalho pode reduzir ainda mais a potência da iluminação geral e, conseqüentemente, o consumo de energia elétrica, gerando também menor carga interna. 


\section{Áreas de eventos}

Devem ser projetados circuitos independentes tanto para o sistema de iluminação artificial quanto para o SAC. Estes ambientes caracterizam-se por sua flexibilidade de usos, com uma variação de ocupação por ambientes de acordo com as necessidades do evento, e que podem determinar a necessidade de equipamentos tais como data show que exigem um controle da iluminação natural e artificial.

Como o foco principal da pesquisa consistiu na análise e avaliação do conforto térmico e da eficiência energética $U H$, foram realizadas medições de temperatura e umidade do ar nas UH em estudo de caso e foram feitas simulações computacionais para fundamentar outras recomendações propostas para a arquitetura desses hotéis em São Paulo.

Verificou-se, nas medições do estudo de caso, que as características construtivas, com teto de laje de concreto armado exposto, forro apenas na área do banheiro onde se concentram os dutos do SAC, determinam uma inércia térmica elevada o que auxiliou em temperaturas internas medidas dentro dos limites de conforto térmico. O forro exposto, WWR menor que 0,4 e cortinas black-out com baixa geração de calor interno estão entre algumas características do caso-base que auxiliaram o bom desempenho térmico da UH. No entanto, esse projeto não deixa de ser padronizado, já que segue as dimensões e especificações da rede hoteleira, sem explorar alternativas no projeto de arquitetura que melhorariam o aproveitamento das estratégias passivas, auxiliando assim na redução do consumo do SAC, constatado como o maior vilão do consumo energético do Hotel Econômico.

$\mathrm{Na}$ avaliação anual das simulações computacionais, verificou-se que as alterações dos componentes construtivos do Cenário 7, com maior inércia do que os anteriores, na seção 6.3, determinou o amortecimento da curva de temperatura diária. O aumento da inércia favoreceu na redução significativa no consumo energético, tanto para aquecimento como para resfriamento.

Observou-se que a ventilação natural pode ser explorada no projeto de arquitetura com ou sem o uso de sistemas mecânicos. Recomenda-se que eles sejam incorporados no projeto de arquitetura para atender a situações em que não há vento, garantindo uma taxa de ventilação e renovação adequada do ar, sem necessariamente depender do SAC. Este poderia funcionar de forma independente, ou aproveitar uma mesma estrutura de dutos do sistema de ar condicionado (caso existam) para a saída do ar no ambiente.

A ventilação natural, seja ela cruzada ou obtida por efeito chaminé, favorece o maior aproveitamento das estratégias passivas. Com isso, há possibilidade 
das redes utilizarem essa característica como estratégia de marketing na "campanha do selo verde", como referida por Chandler (2007) na seção 2.3, valorizando assim as medidas de sustentabilidade tomadas pela rede hoteleira.

Todas essas medidas favorecem o uso de sistemas passivos em detrimento do SAC, no entanto a necessidade de manter o SAC incorpora elementos adicionais (se comparados a projetos pautados apenas em sistemas passivos), mas que podem ser agregados a um projeto de forma eficiente e integrada.

A pesquisa mostrou que a concepção arquitetônica de um hotel deve, portanto, considerar um sistema misto, que integra os sistemas de condicionamento artificial com o natural. Apesar do diagnóstico climático da cidade de São Paulo favorecer o maior aproveitamento das estratégias passivas, as soluções de projeto devem considerar o uso do SAC e todas as implicações relacionadas a ele. Dentre algumas recomendações de projeto, destacam-se as seguintes:

- aproveitar a necessidade dos dutos de saída do ar do SAC também para a ventilação mecânica;

- redimensionar a capacidade do SAC, considerando a capacidade de aproveitamento das estratégias passivas;

- avaliar a possibilidade de ventilação cruzada, com todas as UH em uma mesma orientação e as saídas do ar voltadas para a circulação interna, considerando a necessidade de isolamento acústico do ar que atravessa de um ambiente para o outro;

- avaliar os átrios com pé direito alto, que possam auxiliar na ventilação por efeito chaminé.

Como desdobramento deste estudo, recomenda-se a continuidade da pesquisa em diversos segmentos que podem contribuir no melhor desempenho do edifício hoteleiro:

- A reavaliação dos índices de conforto para os ambientes de uso para dormir, como quartos de hotéis ou dormitórios residenciais. As condições de metabolismo basal, a adaptação do ser humano, nem sempre voluntária, com o uso de quantidades maiores ou menores de cobertas durante o sono, a resistência térmica do colchão, e a dificuldade de se aplicarem questionários nestas condições de uso estão entre alguns dos itens que devem ser incorporados nesta reavaliação.

- O projeto de novas alternativas de caixilhos, tanto para edifícios hoteleiros quanto para edifícios residenciais (nos quartos). O crescimento da cidade implica em níveis de ruído externo cada vez maiores e são necessários novas soluções de caixilhos capazes de evitar a entrada do ruído, sem prejudicar a ventilação natural. 
- A integração de outras alternativas passivas tais como o geotermia ${ }^{28}$.

Em outras pesquisas, pode-se verificar que se trata de um sistema que já vem sendo utilizado em diversos países como estratégia de eficiência energética, compatível com as condições climáticas de São Paulo, apesar de possuir uma amplitude térmica anual bem menor, comparativamente a dos países do hemisfério norte.

- A análise do tempo de retorno do investimento (payback) para as soluções propostas. Muitas vezes, as soluções de projeto refletem em custos de instalação maiores, porém com custos operacionais menores. No ciclo de vida do edifício, através da avaliação do payback, pode-se verificar a viabilidade das soluções propostas, o que determina um melhor desempenho energético do edifício.

- Realizar uma avaliação da eficiência energética através do levantamento de consumo de energia elétrica de diversos hotéis, como instrumento para auxiliar na criação de uma regulamentação energética para edifícios hoteleiros no Brasil.

Um projeto de arquitetura deve sempre e necessariamente contemplar tantos elementos quantos forem possíveis, a fim de proporcionar aos futuros ocupantes, ambientes com espaços únicos e de qualidade, sem que seja preciso abandonar as necessidades básicas de conforto ambiental e de eficiência energética. Não há uma regra a ser seguida, porém as possibilidades de soluções superam os limites dos índices de conforto e do consumo de energia. As pesquisas na área de tecnologia da arquitetura proporcionam subsídios que podem efetivamente contribuir para a qualidade de vida que se reflete no bem-estar do indivíduo. Contudo elas devem, em igual medida, hoje mais do que nunca, levar em conta as variáveis que Ihe tocam e que envolvem, a médio prazo, a proteção e a recuperação do meio ambiente e, a longo prazo, a preservação do espaço maior, o habitat que partilhamos com inúmeras outras formas de vida. Vistas a partir desse âmbito mais amplo, tais pesquisas comprometem-se com as gerações futuras, numa dimensão que extrapola em muito os limites da arquitetura, para visar as necessidades vitais do planeta e a sobrevivência de nossa e de outras espécies.

\footnotetext{
28. Geotermia: estratégia que aproveita da inércia térmica do solo, que mantém, a dois metros de profundidade, a temperatura média anual do local constante e que, por meio de dutos, pode ser utilizada para aproximar a temperatura do ar externo (no verão e no inverno), a temperatura de conforto. O ar que atravessa os dutos pode ser insuflado diretamente nos ambientes, ou no SAC, fazendo-o que este trabalhe com limites de temperaturas mais amenas tanto no ivnerno quanto no verão,tornando-o mais eficiente energeticamente.
} 




\section{Referências bibliográficas}

\section{Bibliografia citada}

ABNT - Instalações Centrais de Ar Condicionado para Conforto - Parâmetros Básicos de Projeto (NBR 6401). Associação Brasileira de Normas Técnicas, Rio de Janeiro, 1980.

ACCOR HOTELS, $2006 . \quad$ Disponivel em:〈http://www.accorhotels.com.br/guiarapido/index.asp〉. Acesso em:12 jul. 2006.

AKUTSU, M. Método para Avaliação do desempenho térmico de edificações no Brasil. Tese (Doutorado) - Faculdade de Arquitetura e Urbanismo, Universidade de São Paulo, São Paulo, 1993.

AIT -Architektur Innerarchitektur Technischer. Bar Hotel Restaurant. Ausbau. jun. 2006

ALUCCI, M. P. Conforto térmico, conforto luminoso e conservação de energia elétrica. Procedimentos para desenvolvimento e avaliação de projeto de edificações. Tese (Doutorado) - Faculdade de Arquitetura e Urbanismo, Universidade de São Paulo, São Paulo, 1992.

Manual para dimensionamento de aberturas e otimização da iluminação natural na arquitetura. São Paulo: FAUUSP, 2006. ISBN: 85-88126-54-O

TAO: Uma metodologia para implantação de edificação: Ênfase no desempenho térmico, acústico, luminoso e energético. Tese (Livre Docência) - Faculdade de Arquitetura e Urbanismo, Universidade de São Paulo (FAUUSP) São Paulo, 2007. 
Programa Climáticus 4.2. São Paulo. 2005. Disponível em:<http://usp.br/fau/ ensino/graduação/software> Acesso em: 01 maio 2007.

ANÁlISE SETORIAL: A Indústria Hoteleira. Relatório da Gazeta Mercantil. (volumes I, II e III). São Paulo: Panorama Setorial, Gazeta Mercantil, 1999.

ANDRADE, N; BRITO, P.L; JORGE, W. E; Hotel: Planejamento e projeto. São Paulo: Senac, 2003.

ANDRADE, C.M. Avaliação de desempenho em edifícios de escritório: o a mbiente de trabaIho como meio para o bem-estar produtivo. 2005. Tese (Doutorado) - Faculdade de Arquitetura e Urbanismo de São Paulo, Universidade de São Paulo (FAUUSP) São Paulo, 2005 .

ANDREASI, W.A., LAMBERTS, R.. Thermal comfort in buildings locates in regions of hote and humid climate of Brasil. Windsor Conference: Comfort and Energy Use in Buildings: Getting them right. Windsor, 27 a 30 de Abr.2006.

ANSI/ ASHRAE - AMERICAN NATIONAL STANDARDS INSTITUTE \& AMERICAN SOCIETY OF HEATING, REFRIGERATING AND AIR-CONDITIONING ENGINEERS. Ventilation and Acceptable Indoor Air Quality in Low-Rise Residential. (ANSI/ ASHRAE 62.2-1989). USA, 1989.

Standard. 55 (2004). Thermal Environmental Conditions for Human Occupancy. (ANSI/ASHRAE Standard 55/2004). American Society of Heating, Refrigerating, and Air-Conditioning Engineers, Inc. USA, 2004.

Standard 90.1 (2004) Energy Standard for Building Except Low-Rise Residential Buildings. (90.1/2004).American Society of Heating, Refrigerating, and Air-Conditioning Engineers, Inc. USA, 2004.

AGÊNCIA NACIONAL DE VIGILÂNCIA SANITÁRIA (ANVISA) Resolução REg. Orientação técnica sobre padrões referenciais de qualidade do ar interior em a mbientes climatizados artificialmente de uso público e coletivo. Brasília: Anvisa, 2003. Disponível em: <http://www.anvisa.gov.br/legis/portarias/3523_98.htm> Acesso em 22 abr. 2007.

Resolução 176. Disponível em: <http://www.anvisa.gov.br/legis/portarias/3523_98.htm> Acesso em 22 abr. 2007.

ARNOLD, D. Mixed Mode HVAC. An alternative Philosophy. ASHRAE Transactions, v.102, n.1, 1996.

BACELLAR, M. C. B.; CHAGAS, J. A. C. Racionalização de Energia em Instalações de Refrigeração: Soluções técnicas diferenciadas para resfriamento e Congelamento de alimentos e bebidas In: Anais da Conferência do Encontro Nacional Conforto no Ambiente Construído, Curitiba, 2003. 1 CD-ROM.

BALCOMB, D. The coming revolution in Building Design In: Environmentally friendly Cities, Proceedings of Plea 98, P. 33-37. Lisbon: James\&James Science Publishers Ltd., June 1998.

BARING, João Gualberto de Azevedo. Contribuições para a correta resolução acústica de edifícios. Dissertação (Mestrado). Faculdade de Arquitetura e Urbanismo de São Paulo (FAUUSP). São Paulo, 1981. 
BARING, João Gualberto de Azevedo. O desempenho Acústico de caixilhos de fachada no contexto do controle da poluição sonora urbana. Tese (Doutorado). Faculdade de Arquitetura e Urbanismo de São Paulo (FAUUSP). São Paulo, 1990.

BALANÇO ENERGÉTICO NACIONAL (BEN) Disponível em: < http://www.mme.gov.br/ site/menu/select_main_menu_item.do?channelld $=1432 \&$ pageld $=10646\rangle$. Acesso em: 10 dez. 2006.

BITTENCOURT, L.; CÂNDIDO, C.. Introdução à Ventilação Natural. Maceió: EDUFAL, 2005.

Bogo, A, Pietrobon, C. e, barbosa, M. J., Goulart, S., PittA, T., LAmberts, R. Bioclimatologia Aplicada ao Projeto de Edificações visando o conforto térmico. 1994. 83p. Relatório Interno n. 02/94 - Núcleo de Pesquisa em Construção, Departamento de Engenharia Civil, Universidade Federal de Santa Catarina. Disponivel em: <http://www.labeee.ufsc.br/linhas_pesquisa/BIO.html> Acesso em: 4 nov. 2007.

BOLETIM EFICIÊNCIA ENERGÉTICA 33/05 - Hotéis e Eficiência Energética - Uma Parceria para o Presente e Futuro. 25 de julho de 2005 Disponível em... <http://www.abesco.com.br/datarobot/> Acesso em: 25 ago. 2005.

BRANDÃO, R. S. Acesso ao Sol e à Luz Natural: Avaliação do impacto de novas edificações no desempenho térmico, luminoso e energético do seu entorno. Dissertação (Mestrado). Faculdade de Arquitetura e Urbanismo de São Paulo, Universidade de São Paulo(FAUUSP), São Paulo, 2004.

BUARRAJ, M. Arquitetura de hotéis na cidade de São Paulo: projetos arquitetônicos, operação, manutenção e tecnologia. 2003, 223f. Dissertação (Mestrado), Faculdade de Arquitetura e Urbanismo, Universidade de São Paulo (FAUUSP), São Paulo, 2003.

BUORO, A. B., De BENEDETTO, G.S., MUIRA, O.U. Consumo de energia elétrica \& conforto ambiental, avaliação e proposta. Estudo de caso: Hotel Econômico. Trabalho de conclusão de curso CECACE III: Curso de especialização em Conforto Ambiental e Conservação de Energia, São Paulo, 2003.

BUORO, A. B., De BENEDETTO, G.S., MUIRA, O.U.K., ROMÉRO M. A., Conforto, consumo de energia e uso do ar condicionado em hotel de categoria econômica: Estudo de caso em hotel de São Paulo. Anais do: CIAR 2005 - VIII Congresso Ibero Americano de Aire Acondicionado y Refrigeracion. Montevidéu, Uruguai, 2004.

Conforto, Consumo de Energia e Uso do Ar Condicionado em Hotel de Categoria Econômica: Estudo de caso em hotel em São Paulo. In: MERCOFRIO 2004 - IV Feira e Congresso de Ar Condicionado, Refrigeração e Ventilação do Mercosul, 14 a 17 set. 2004, Curitiba. Anais eletrônicos do IV MERCOFRIO, 2004. 1 CD-ROM.

BUORO, A. B.; MESQUITA, M. J. ; ORNSTEIN, S. W. ; BRUNA, G. C.; MELHADO, S.B. . Avaliação Pós-Ocupação aplicada ao Conforto Ambiental de Hotel em São Paulo. Anais do: ENCAC COTEDI, Curitiba, Brasil, 2003.1 CD-ROAM.

CADERNO BRASILEIRO DE AROUUTETURA. No 19. São Paulo: Projeto Editores Associados, 1987.

CHANDLER, C. A few things to keep in Mind When Marketing You Green Hotel. 9 janeiro 
2007. Disponivel em: 〈http://www.greenlodgingnews.com/Content.aspx?id=741> Acesso em: 9 abril 2007 .

CLETO, L.T. HERNANDEZ NETO, A A eficiência energética em equipamentos do sistema de climatização. Revista Climatização Ano VI No 76 Dez. 2006.págs.31 a 38

CORBELLA, O; YANNAS, S. Em busca de uma arquitetura sustentável para os trópicos Conforto Ambiental. Rio de Janeiro: Revan, 2003.

CORREIA, P.; Avaliação do mercado de eficiência energética no Brasil: pesquisa na classe comercial. Workshop: avaliação de mercado de eficiência energética no Brasil, 2007. Disponivel em: 〈http://www.eletrobras.com>. Acesso em: 25 abr.2007.

DAVID, J.L. Architecture and the Environment. London, Laurence King Publishing.1998.

De BenedetTo, G.S. Análise de dados climáticos: São Paulo e Rio de Janeiro. 2006. 55 f. Trabalho Programado 1 do Curso de Pós-Graduação em Arquitetura e urbanismo (Mestrado) - Faculdade de Arquitetura e Urbanismo, Universidade de São Paulo (FAUUSP), São Paulo, 2006.

De BENEDETTO, G.S. Avaliação da aplicação do modo misto na redução da carga térmica em edifícios de escritórios nas cidades de São Paulo e Rio de Janeiro. Dissertação (Mestrado)- Faculdade de Arquitetura e Urbanismo, Universidade de São Paulo(FAUUSP), São Paulo, 2007.

De DEAR, R.; BRAEGER, G.; COOPER, D. Developing an adaptive model of thermal comfort and preference. Sydney: ASHRAE, 1997. (ASHRAE FINAL REPORT RP-884).

DELBIN, S.; SILVA, V.G. Energy Efficiency Simulation of Buildings in Brazil: Proposal of Methodology for insertion in Desing Practice. The 2005 Wordl Sustainable Conference. Tokyo, 27-29 sep. 2005.1CD ROAM.

DEL CARLO, Ualfrido. Acústica dos escritórios panorâmicos. Tese (Doutorado) Faculdade de Arquitetura e Urbanismo, Universidade de São Paulo (FAUUSP), São Paulo, 1972.

DOCZI, G. O Poder dos Limites: harmonias e proporções na natureza, arte e arquitetura. São Paulo: Mercúrio, 1990.

DUARTE, V. V. Administração de sistemas hoteleiros: conceitos básicos. $3^{\mathrm{a}}$ ed. São Paulo: Senac, 2005

EERE, 2007. Disponivel em:<Http://www.eere.energy.gov/consumer/your_home/space_heating_cooling/index.cfm/mytopic=12350> Acesso em: 03 abr. 2007

ELETROBRAS, 2007. Disponivel em: <http://www.eletrobras.com/elb/main.asp?ViewlD= \%7BD81425AF-257E-44E9-8BoF-1F885CD35D6D\%7D > Acesso em: 28 jan. 2007.

EMBRATUR. Deliberação Normativa No 433. Dez/2002. Disponivel em: <http://www. EMBRATUR.com.br.> Acesso em: 15 jul. 2006.

EUROPEAN COMMON RESEARCH CENTER. European Concerted action on indoor quality and its impact on man, Report on ventilation and indoor quality, European Common 
Research Center, Spra. Italy,1996.

EVANS, J.M. The comfort triangles: a new tool for bioclimatic design. Tese (Doutorado) Delft University Technology, Holanda, 2007. Disponivel em: http://www.library.tudelft. $\mathrm{nl} / \mathrm{ws} / \mathrm{search} /$ publications/search/metadata/index.htm?docname=374779> Acesso em: 28 out. 2007.

FANGER, P.O. Thermal Comfort: analysis y applications in environmental engeneering, McGraw Hill Book Company, New York, 1973.

FIORELLI, F..S.; HERNANDEZ, A. N.; TRIBESS, A.. Avaliação de estratégia para racionalização do consumo de energia em edifícios com ar condicionado. In: Anais do ENCAC. Campinas, 2001. 1 CD-ROM.

FORDHAM, M. Comfort and extreme Climates. Windsor Conference: Comfort and Energy Use in Buildings: Getting them right. Windsor, 27 a 30 apr.2006.

FROTA, A. B.; SCHIFFER, S. R. Manual de Conforto Térmico. São Paulo: Studio Nobel, 2001.

GONÇALVES, J . C.S., VIANNA, N. S. Iluminação e Arquitetura. Vitrus s/c Ltda. São Paulo, SP, 2001.

GOOGLE EARTH, 2007. Disponível em: < http:// googleearth.com> Acesso em: 12 abr. 2007.

HILTON.,2007. Disponível em: 〈http:// www.greenseal.org> Acesso em: 9 abr. 2007.

HOUAISS, A.; VILLAR, M. S.; Dicionário HOUAISS da língua Portuguesa. Elaborado pelo Instituto Antonio Houaiss de Lexicografia e Banco de Dados da Língua Portuguesa S/C Ltda.-Rio de Janeiro:Ed Objetiva ISBN 85-7302-383-X. 2004.

HUMPHREYS, M.A.. Comfort temperatures and climate. Standards for thermal comfort. F.Nicol, M.Humphreys, O.Sykes and S.Roaf, eds. London: Chaspman \& Hall, 1995.

HUMPHREYS, M.A.; NICOL, J.F. (2002) The validity of ISO- PMV for predicting comfort votes in every-day thermal environments. Energy and Buildings, Vol 34.pp.667-684.

INEE. A eficiência Energética e o novo Modelo do Setor Energético. Agosto de 2001.Disponivel em: < http://www.inee.org.br>Acesso em: 22 abr. 2007.

ISO 7730/1994- INTERNATIONAL ORGANIZATION FOR STANDARDIZATION. (ISO 7730): Moderate Thermal Environmets: Determination Of the PMV and PPD Índices and Specification Of the Conditions for Thermal Comfort. Geneva, 1994.

JABARDO, J. M. S. Conforto Térmico. Publicação IPT nº 1598. Série Comunicação Técnica 348. São Paulo: IPT, Instituto de Pesquisas Tecnológicas do Estado de São Paulo S/A., 1984. 21p. il.

JABARDO, J. M. S., Evolução dos equipamentos de ar condicionado visando. In:COBEM 2003 - 17th Internacional Congress of Mechanical Engineering. 2003.

JACOB, C. S. C. O Hotel como agente indutor de expansão urbana e desenvolvimento imobiliário. In: VI Seminário LARES. 16 e 17 de Nov. 2006. São Paulo. 1 CD-ROM.

JONES,, J.L. Architecture and the Environment. London, Laurence King Publishing.1998.

JUMEIRAH. Disponivel em:<http://www.jumeirah.com/press_centre/>. Acesso em: 10 dez. 2007 . 
KRONKA, R. Arquitetura de Baixo Impacto Humano e Ambiental. Tese (Doutorado). Faculdade de Arquitetura e Urbanismo, Universidade de São Paulo (FAUUSP), 2002.

LAMBERTS, R.; DUTRA, L. PEREIRA, F.O.R. Eficiência energética na arquitetura. São Paulo: Prolivros, 1997.

LAWSON, F. Hotel and resorts: planning and design. 2 ed. London: Architectural PRESS, 1995

LEGISLAÇÃO brasileira. Lei 4192. Disponivel em: <http://www.ar-limpo.com.br/legislacao/le4192.htm> Acesso em: 22 abr. 2007.

LIBBY, B. Hilton Aims to Become First LEED - Rated Hotel: Sustainable Metropolis. 19 julho 2005. Disponivel em: 〈http://www. metropolismag.com/cda/story.php?artid=1497〉 Acesso em: 9 abr. 2007 .

LIMA, R.A.P.F. $\mathbf{O}$ avanço das redes hoteleiras internacionais no Brasil. Tese (Doutorado). Escola de Comunicação e Artes, Universidade de São Paulo (ECA USP), 2003.

LINZMAYER, E. Guia básico para administração da manutenção hoteleira. São Paulo. Ed. Senac, 2002.126p.

Questões operacionais do hotel e seu edifício. (depoimento a Munir Buarraj). In: BUARRAJ, M. Arquitetura de hotéis na cidade de São Paulo: projetos arquitetônicos, operação, manutenção e tecnologia. 2003, 223f. Dissertação (Mestrado), Faculdade de Arquitetura e Urbanismo, Universidade de São Paulo (FAUUSP), São Paulo, 2003.

LIMA, R. A. P. F. 0 avanço das redes hoteleiras internacionais no Brasil. Tese (Doutorado) Escola de Comunicação e Artes (ECA), Universidade de São Paulo (USP), 2003.

MASCARÓ, J.L.; MASCARÓ, L. Incidência das variáveis projetivas e de construção no consumo energético dos edifícios. Porto Alegre: Sagra-DC Luzzatto Editores, 1992.

MESQUITA, M.J. Subsídios para o planejamento da qualidade em edifícios do segmento hoteleiro. Tese (Doutorado). Escola Politécnica, Universidade de São Paulo (EPUSP). São Paulo, 2006.

MUELLER, C.M. Espaços de ensino-aprendizagem com qualidade ambiental: o processo metodológico para elaboração de um anteprojeto. Dissertação (Mestrado). Faculdade de Arquitetura e Urbanismo, Universidade de São Paulo (FAUUSP), São Paulo, 2007.

OLGAY, V. Design with Climate: Bioclimatic Approach to Architectural Regionalism. New Jersey: Princeton University Press, 1963.

OLIVEIRA. VAV permite Revista Climatização. Ano 2 número 12 - Editora RPA 12 de ago. de 2001.

PANORAMIO, 2007. Disponivel em:<http://www.panoramio.com/photo/421402>. Acesso em: 12 abr. 2007.

Regulamentação para Etiquetagem Voluntária de Nivel de Eficiência Energética de Edifícios Comerciais, de Serviços e Públicos. Disponível em: <http://www.labeee.ufsc.br/ eletrobras/reg.etiquetagem.voluntaria.html> Acesso em 07 abr. 2007. 
REVISTA DO FRIO. Disponivel em: <http://www.revistadofrio.com.br/revistas/edicaomes-09-02a.htm> Acesso em: 22 ago. 2005.

REVISTA HOSPEDAGEM BRASIL. Associação Brasileira da Indústria Hoteleira (ABIH). Ago, 2002. Disponivel em: 〈http://www.abih.com.br.>Acesso em: 15 jul. 2006.

REVISTA PROJETO: Tendências e desenho dos hotéis do futuro. São Paulo, pg.136, 1990.

REVISTA VEJA: Revista semanal. "Bons e Baratos". 1990. Disponivel em: <http://veja.abril.com.br.> Acesso em: 9 jun. 2005.

REVISTA VEJA. Guia Imobiliário. 2006. Disponível em: 〈http://veja.abril.com.br〉. Acesso em: 10 jul. 2006.

ROMERO. M. A. Arquitetura, Comportamento e energia. Livre-docência.Faculdade de Arquitetura e Urbanismo, Universidade de São Paulo. São Paulo,1997.

SAINT GOBAIN GLASS, 2007. Disponivel em: http://saint_gobain-glass.com.br/paginas/produto-conforto.htm. Acesso em: 30 abr. 2007.

SALANI, F. Cinco Estados terão $\mathbf{5 8 \%}$ dos novos hotéis até 2009. Caderno Dinheiro:Folha de São Paulo, 23 nov. 2006.

SANTAMOURIS, M.; ALLARD, F. Natural ventilation in buildings: a design handbook. London: James and James, 1998.

SANTAMOURIS, M.; ASIMAKOPOULOS, D. Editors. Passive Cooling of buildings. London: James \& James Ltd, 1996. ISBN- 1873936478.

SANTOS, R.F.; MARTINS, J.M.V. Influência de parâmetros arquitetônicos no consumo de energia elétrica. In: REVISTA Climatização São Paulo, v.2, n.24, p.36-45, ago, 2002.

SILVA, V.G. Avaliação da sustentabilidade de edifícios brasileiros: diretrizes e base metodológica. Tese (Doutorado). Escola Politécnica da Universidade de São Paulo (EPUSP). São Paulo, 2003.

SIQUEIRA, C.P.A.; AKUTSU, M.; LOPES J.I.E.; SOUZA, H.A. Dados climáticos para avaliação de desempenho térmico de edificações. Revista Escola de Minas, Ouro Preto, 58(2): 133-138, abr.jun.2005. Disponível em: < http://www.scielo.br/scielo.php?script=sci_arttext\&pid= S0370-44672005000200007 >. Acesso em: 10 nov.2007. ISSN 0370-4467.

SOUZA, R. Avaliação do mercado de eficiência energética no Brasil: Pesquisa na classe Comércio e Industria Baixa Tensão DEE\&IEPUC; PUC-Rio, Workshop: avaliação de mercado de eficiência energética no Brasil, 2007. Disponivel em:<http://www.eletrobras.com/>. Acesso em: 25 abr. 2007.

TAS NG (v.9.0.6, 2005) Environmental Design Solutions Limited.

THE GUARDIAN, Editorial.. Going Green and Meaning it. The Guardian. A Guardian Editorial. 28 abr. 2007. Disponível em: < http://www.guardian.co.uk/commentisfree/story/o,2067605,00.html>. Acesso em: 31 abr. 2007.

TORCELLINE.P.A.; PLESS,S.D.; JUDKOFF,R. Solar technologies \&The building Envelope. ASHRAE Journal Abr, 2007. Disponível em: 〈httt://www.ashrae.org〉 acesso em 30 abr. 
2007.

TRAVELHERO. Disponivel em: http://www.travelhero.com/photos.cfm?id=140213. Acesso em: 4 abr. 2007.

TRIPADVISOR. Disponível em: <http://www.tripadvisor.com/Hotel_Review-g298184d307378-Reviews-Royal_Park_Shiodome_Tower-Tokyo_Kanto.html >. Acesso em: 4 abr. 2007.

TUCH, David Lord. Planejamento Fisico de Hotéis - Seminário: Arquitetura e Design de Hotéis no Brasil: SENAC, 1980.

UNEP, 2007. United Nation Environment Programe. Building and Climate Change: Status, Challenges and opportunities. Disponivel em: <http://www.unep. org/Documents. Multilingual/Default.asp? Document $\mid \mathrm{D}=502 \&$ Article $|\mathrm{D}=5545 \&|=e n>$ Acesso em: 2 abr. 2007.

VITRINE HOTEL. 4 Hotéis em 1 operando com o tarifário simplex seqüencial econômico. Disponivel em:< http://www.vitrinehotel.com.br/pro_age_rel_alt.asp? modo=ler\&ID= 8505>. Acesso em: 8 abr. 2007.

VOSGUERITCHIAN, A.B. A abordagem dos sistemas de avaliação de sustentabilidade da arquitetura nos quesitos ambientais de energia, materiais e água, e suas associações às inovações tecnológicas. Dissertação (Mestrado) - Faculdade de Arquitetura e Urbanismo, Universidade de São Paulo, (FAUUSP), São Paulo, 2006.

WEISE, A. D. ; CARIONI, A. Z. Fatores que influenciam a avaliação de hotéis In: VI Seminário LARES. 16 e 17 de Novembro. 2006, São Paulo. 1 CD-ROM.

WERNECK, F.; Metodologia da Avaliação das edificações "sustentáveis"- definição explícita da qualidade ambiental em edifícios. Anais do ENCAC - COTEDI 2003. 5 a 7 de Nov, 2003.

WIKIPEDIA, 2007.Disponível em:<http://en.wikipedia.org>. Acesso em: 2007

WORLDGBC, 2007. Disponivel em: <http://www.worldgbc.org/docs/ShiodomeTower.pdf<. Acesso em: 27 mar. 2007

WTO, 2006. Disponivel em:<http://www.world-tourism.org/>. Acesso em:14 ago. 2006.

WTO; IR\&RA. World Tourism Organization (WTO); International Hotel\& Restaurant Association (IH\&RA). The Join WTO \& IH\&RA. Study on Hotel Classification. 2005. Disponivel em: < http://www.ih-ra.com/marketplace/WTO_IHRA_Hotel_classification_study.pdf> Acesso em: 20 out. 2005.

WTTC Focuses Debate on Climate Change with Global Ad Campaign. Disponivel em: http://www.greenlodgingnews.com/Content.aspx?id=945. Acesso em: 9 abr. 2007

ZAKABI, Rosana. "A Vez dos SEM_estrelas". Revista Veja, Edição 1766- 28 Ago, 2002. Disponivel em: 〈http://veja.abril.com.br〉. Acesso em: 10 abr. 2006. 


\title{
Bibliografia consultada
}

\begin{abstract}
Air Conditioning Engineering. A home-Study Course and General Reference Work on the principles, Design, Selection, and Application of heating and air-conditioning appliances and systems for residential, commercial, Industrial Use. Published by: America Technical Society. Chicago, U.S.A, 1938.

AKKERMAN, S. Tratamento Acústico do Ar Condicionado e Ventilação. In: $1^{\circ}$ Seminário de acústica arquitetônica contemporânea - Conteúdo das Palestras. São Paulo, 2005.

ALLARD, F.; GHIAUS, C.; MANSOURI, Y. Natural ventilation for health, comfort and energy efficiency. In: ENCAC-COTEDI 2003 - Encontro Nacional Conforto Ambiental - Conforto e Eficiência Energética na Arquitetura Latino Americana. Anais eletrônicos Curitiba. Conferência ENCAC-COTEDI 2003, 2003.1 CD-ROM.
\end{abstract}

ALUCCI, M. P Recomendações para adequação de uma edificação ao clima, no Estado de São Paulo. Dissertação (Mestrado) - Faculdade de Arquitetura e Urbanismo, Universidade de São Paulo, São Paulo, 1981.

BUARAJ, M. A Evolução Tecnológica na Construção de Hotéis. Dissertação (Mestrado) Faculdade de Arquitetura e Urbanismo, Universidade de São Paulo (FAUUSP), São Paulo, 2004.

BUORO, A.B. Bando de Dados de Sistemas de Ar Condicionado: Janela e Split com selo PROCEL. Trabalho em andamento.2007. Faculdade de Arquitetura e Urbanismo de São Paulo (FAUUSP). 
BUYS, J.H.; MATHEWS, E.H.. Investigation into capital costs of HVAC systems. Build and Environment. Disponivel em: 〈http://www.elsevier.com/locate/buildenv>Acesso em: 2 abr 2005 .

CROCKER, M.J.; ARENAS,J; Dyamannavar, R.E. Identification of noise sources on a residential split-system air-conditioner using sound intensity measurements. Applied Acoustics 65 (2004) 545-558.

DENG, S.; BUMETT, J. A study of energy performance of hotel buildings in Hong Kong. Energy and Buildings 31 (20000) 7 - 12, 2000.

DI MARCO, A.R, C (coord. edição) Os componentes da Indústria Hoteleira. Cadernos Brasileiros de Arquitetura 19 Projeto Editores Associados Ltda., 1987. (pg 40)

EERE, 2007. Disponivel em"<www.eere.energy.gov/consumer/your_home/space_heating_cooling/index.cfm/mytopic $=12350>$ Acesso em: 03 abr. 2007

FANGER, P.O., TOFTUM, J. Extension of the PMV model to non-air-conditioned buildings in warm climates. Energy and Buildings 34 (2002) 533-536.

FANTINI, L. B.D. Arquitetura hoteleira: avaliação de duas categorias na cidade de São Paulo: Elementos de Montagem de um método de projeto. Dissertação (Mestrado) - Faculdade de Arquitetura e Urbanismo, Universidade de São Paulo (FAUUSP), São Paulo, 2004.

FIORELLI, F..S.; HERNANDEZ, A. N.; TRIBESS, A. Avaliação de estratégia para racionalização do consumo de energia em edifícios com ar condicionado. In: Anais do ENCAC. Campinas, 2001. 1 CD-ROM.

GONTIJO FILHO, P. P.; SILVA, C. R. M. e KRITSKI, A. L. Ambientes climatizados, portaria 3.523 de 28/8/98 do Ministério da Saúde e padrões de qualidade do ar de interiores do Brasil. J. Pneumologia. [online]. set./out. 2000, vol.26, no.5 [citado 21 Agosto 2005], p.254-258. Disponivel em: <http://www.scielo.br/scielo.php?script=sci_arttext\&pid=S0102$35862000000500006 \& \operatorname{lng}=p t \& n r m=i s 0>$. Acesso em: 10 ago. 2005. ISSN 0102-3586.

GOULDING, J. R.; LEWIS, J. O.; STEEMERS, T. C. (ed). Energy Conscious Design. Batsford for the Commission of European Communities. London, 1993.

HANSEN, S. J. Managing Indoor Air Quality. Lilburn: The Fairmont Press, 1991.

HAWKES, D. Energy efficient building : architecture, engineering, and environment / Dean Hawkes and Wayne Forster. New York: W.W. Norton \& Co., C2002.

HERNANDEZ NETO, A. Carga térmica em edificações climatizadas. In: REVISTA Climatização São Paulo, v.5, n.55, p.48-51, mar, 2005.

HERNANDEZ NETO, A., TRIBESS, A., FIORELLI, F.A.S. Evaluation of thermal performance index for air conditioning commercial buildings. In: COBEM 2003: Proceedings São Paulo: ABCM, 2003.

HERTZBERGER, H. Lições de Arquitetura. 2 ed. São Paulo: Martins Fontes, 1999.

IZARD, J. L.; GUYOT, A. A arquitetura Bioclimática. Barcelona: Gustavo Gilli,1980.

KONTOLEON, K.J.; BIKAS, D.K. The influence of the zone's indoor temperature settings on 
the cooling/heating loads for fixed and controlled ventilation. Disponivel em: <http://www.elsevier.com/locate/buildenv〉. Acesso em: 2 abr 2005.

KRÜGER, J.J. The calculation of actively absorbing silencers in rectangular ducts. Journal of Sound and Vibration (2002) 257(5), 887-902.

LAMBERTS, R. Lei da Eficiência Energética em Edificações e Sistemas de HVAC. In: Anais do MERCOFRIO. Curitiba, 14 a 17 de Setembro 2004. 1 CD-ROM.

LEITE,B.C.C. Sistema de Ar Condicionado com insuflamento pelo piso em ambientes de escritório. Avaliação do conforto térmico e condições de operação. Tese (doutorado) Escola Politécnica da Universidade de São Paulo (EPUSP). São Paulo. 162p. 2003

LIDDAMENT. M. W. A Guide to Energy Efficient Ventilation. AIVC - Air Infiltration and Ventilation Centre. Great Britain, 1996.

LUSH, D.M. A review of air conditioning systems: their application and economics. In: Sherratt AFC, editor. Air conditioning system design for buildings. (Pg.44-55)New York: McGraw-Hill , 1983.

MARCONDES,M.P. Double-Skin façades high-rise office buildings in São Paulo. A possible environmental efficient solution? 2004. Dissertação (Mestrado) - AA Graduate School MA Environment \& Energy Studies.London, 2004.

MASCARÓ, J.L. Consumo de Energia e Construção de Edifícios. São Paulo: SECOVI, 1981.

MASCARÓ, J.L., MASCARÓ, L.; Incidência das variáveis projetivas e de construção no consumo energético dos edifícios. Porto Alegre: Sagra-DC Luzzatto Editores, 1992.

MASCARÓ, J.L.; Consumo de Energia e Construção de Edifícios. São Paulo, SECOVI, 1981.

MONBIOT, G. The rich Word's Policy on Greenhouse Gas Now Seems Clear: Millions Will Die. The Guardian. Publicado em 1 maio 2007.Disponível em:< http://www.commondreams.org . Acesso em: 2 maio 2007.

MOORE, F. Environmental Control Systems, Heating, Cooling, Lighting. New York: McGrawHill, 1993.

MOTTILLO, M. Sensitivity Analysis of Energy Simulation by building. ASHRAE Transactions 2001 (2) - pg 722,731.

OLIVEIRA. VAV permite Revista Climatização. Ano 2 número 12 - Editora RPA 12 de ago. de 2001.

PFAFFEROTT, J, HERKEL, S.. KALZ, D, Zeuschner. Comparison of Low-Energy Office Buildings in Summer using different Thermal Comforto Criteria. Windsor Conference (2006).1CDROAM.

POOLE, A.D., GUIMARÃES, E.T. Steps Towards Building an effective Energy Efficiency Strategy in Brazil.Report Prepared for the Brazialin Group on Financing Energy Efficiency coordinated by Ibmec.(Jun.2003). Disponível em: < http://www.inee.org.br >. Acesso em: 22 abr. 2007.

RACINE, T. A. P. A saúde dos prédios em exame. Disponível em: <http://www.revista.- 
fapesp.br> Acesso em: 04 set. 2005.

ROMERO. M. A. Arquitetura, Comportamento e energia. Livre-docência. Faculdade de Arquitetura e Urbanismo, Universidade de São Paulo. São Paulo, 1997.

ROSENQUUIST, G., MC MAHON, j., CHAN, P., BUSKIRK,R.V., LEKOV, A. Consumer Life-Cycle Cost Impacts of energy- Efficiency Stands for residential- Type Central Air Conditioner and Heat Pumps. ASHRAE Transactions 2003 (2) -pg 619-630.

SCHAFFER, M.E. A Practical Guide to Noise and Vibration Control For HVAC Systems.

ASHRAE, American Society of Heating, refrigerating and Air-Conditioning Engineers. Inc. Atlanta, 1992.

SILVA, P. Acústica Arquitetônica e Condicionamento de Ar. 5 a ed. Belo Horizonte: Edital, 2005 .

STEC, W.J..; VAN PAASSEN, A.H.C.; Symbiosis of the double skin façade with the HVAC system. Energy and buildings 37 (2005) 461-469, 2005.

STOECKER, W.F.; JONES, J.W. Refrigeração e Ar Condicionado. São Paulo, McGraw-Hill do Brasil. 1985.

SZOKOLAY, S.V. Thermal design of buildings. The Royal Australian Institute of Architects, Australia, 1995.

TANG, S.K.; WONG, M.Y. On noise indices for domestic air conditioners. Journal of Sound and Vibration 274 (2004) 1-12.

TOLEDO, A. M.; PEREIRA, F. O.R. Metodologia de Avaliação multicritério de ventilação natural :detalhamento para aplicação em apartamentos. In: Anais da ENCAC COTEDI, Curitiba, 2003. 1 CD-ROM.

TORREIRA, R. P. Elementos de Ar Condicionado. São Paulo: Hemus, 1983 e. 1876.

TORREIRA, R. P. Energy signatures for assessing the energy performance of chillers. Energy and buildings 37 (2005) 739-746, 2005.

Yu, F.W., CHAN, K.T. Economic benefits of improves features for air-cooled chillers serving an air-conditioned hotel. Science Direct 26(2006) 1063-1073.

YU, F.W., CHAN, K.T. Eletricity end-use characteristics of air-cooled chillers in hotels in Hong Kong. Building and Environment 40 (2005) 143-151, 2005. 




\section{Apêndice A Levantamento de dados Empíricos - Estudo de Caso}

Com base no parque hoteleiro de São Paulo e na rede internacional estudada neste trabalho, verificou-se a disponibilidade de acesso ao Hotel modelo, para que fossem feitas as medições simultâneas de temperatura do ar, umidade do ar e temperatura de globo em dois apartamentos, situados em faces opostas de um mesmo andar.

O levantamento dos dados foi possível pela conjunção de dois fatores fundamentais: o interesse pela pesquisa, demonstrado pelo gerente do hotel selecionado, e o período de baixa ocupação. A baixa ocupação do hotel durante o verão e a recente finalização da transformação de um andar de fumantes para não fumantes possibilitou o funcionamento diário e contínuo dos equipamentos, sem interferência externa.

A disponibilidade dos apartamentos foi fator limitador para se obter um único ciclo de medidas efetuadas, juntamente com a restrição de uso dos equipamentos do LABAUT e do IPT, o qual permaneceu limitado devido ao período de forte demanda para outras pesquisas. As restrições possibilitaram apenas um ciclo de medições de cinco dias consecutivos, dos quais os três últimos com ocupação com os "hóspedes de controle" (ver Apêndice C).

Desses três dias ocupados, o mais representativo escolhido foi o terceiro com ocupação, para que o efeito nas condições ambientais internas dos apartamentos nos quais foram posicionados os sensores fosse avaliado. Os dados tratados para o dia mais representativo foram, então, avaliados, considerando-se as respostas do "hóspede de controle". 


\section{Metodologia}

O período em que ocorreram as medições foi composto de 5 dias consecutivos, do dia 8 ao dia 12 de Janeiro de 2007. As medições foram realizadas em dois apartamentos, situados frente a frente, simultaneamente. A ocupação das unidades habitacionais (UH) foi controlada pela pesquisadora por meio de uma cartilha de ocupação com um questionário (Apêndice B). Foram mantidas as janelas fechadas e o sistema de ar condicionado desligado (apenas com a ventilação mecânica permanente) durante toda a ocupação.

O questionário foi entregue aos ocupantes dos apartamentos antes de seu ingresso nas UH para que, após definido o dia mais representativo e a partir de seus comentários, fossem avaliados e confrontados esses dois dias com as medidas obtidas.

A localização dos sensores em relação à altura do solo, bem como as recomendações de posicionamento dos ocupantes no ambiente seguiram as recomendações da norma ISO 7726/98. A altura dos sensores foi decidida considerando-se um adulto sentado e, portando, IL. 105.

O termômetro de globo preto utilizado para medir a temperatura de globo e, posteriormente, para calcular a temperatura radiante média, foi posicionado na mesma altura do sensor de temperatura e disposto de modo a não barrar a circulação de ar entre ambos nem receber radiação direta no mesmo.

As medidas foram feitas simultaneamente nas UH face SO e face NE. No quarto face NE, por incidir no período do ano medido menos horas de radiação direta, foram efetuadas outras duas medições: um sensor estava suspenso na bancada de trabalho próxima a janela e o outro, na parte externa da janela, distando $10 \mathrm{~cm}$ da envoltória (conforme indicado na IL. 106). Ambos foram protegidos por fita adesiva metalizada, para não receber interferência das trocas por convecção provenientes da envoltória.

As variáveis medidas internamente foram: temperatura de globo, temperatura do ar, umidade relativa, massa de vapor d'água por grama de ar e ponto de orvalho.

As variáveis medidas externamente foram: temperatura do ar, velocidade do ar e umidade relativa do ar. Também foram obtidos dados da Estação Meteorológica do IAG USP, situada no Parque do Estado, em São Paulo.

Os equipamentos utilizados estão apresentados a seguir. 
AMBIENTES HOMOGENEOS - CLASSES CONFORTO E ESTRESSE

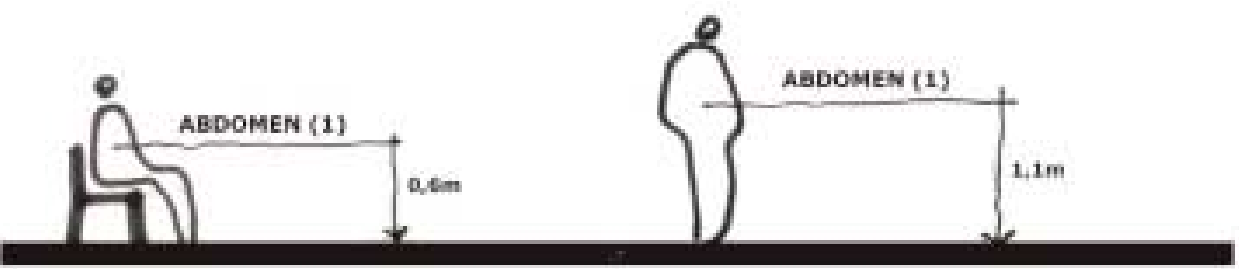

Ilustração 105: Posição dos sensores normatizada pela ISO7726/98 para medição dos parâmetros físicos do ambiente homogêneo.

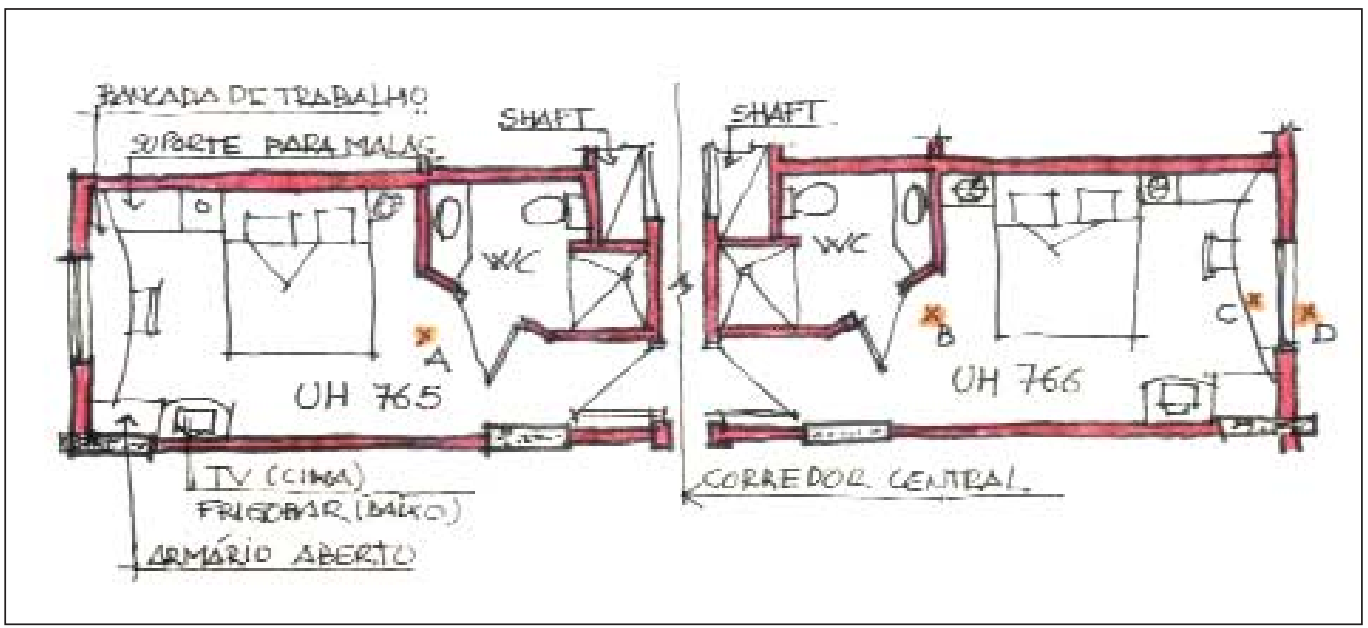

Ilustração 106: Planta dos apartamentos do estudo de caso com posicionamento dos sensores nos pontos A(quarto 765) e B, C e D (quarto 766).

\subsection{Equipamentos utilizados na medição interna}

Nas medições internas, foi utilizado o data logger ALMEMO 2290-8 com sete canais disponiveis para conectar os termopares (quatro) e duas sondas Almemo AFHA646 (que medem a temperatura, umidade relativa, ponto de orvaIho e massa de vapor da água no ar), conforme IL. 107. O data logger tem uma precisão de $0,3{ }^{\circ} \mathrm{C}$ e as medidas são registradas a cada 10 minutos, a partir o acionamento do equipamento.

Segundo as recomendações da norma ISO 7726/98, em cada UH foi posicionado, no interior de um globo negro de $15 \mathrm{~cm}$, um termopar por globo, para obter a temperatura de globo. 


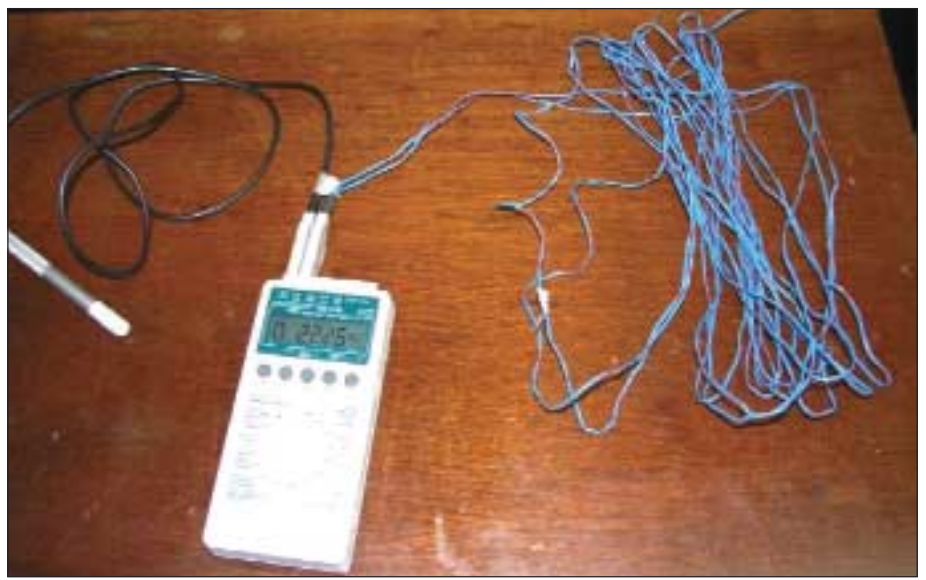

Ilustração 107: Data Logger AIMEMO 2290-8 com sonda de TBS e UR ALMEMO e termopar.

Os dois globos foram posicionados eqüidistantes nas duas UH; o data logger ficou disposto na UH face Sudoeste (IL. 108), onde outros dois termopares foram posicionados sobre a bancada em frente a janela (IL. 109), e na face externa do caixilho (IL. 110)

\subsection{Seleção das UH a serem utilizadas}

A aluna teve a liberdade, perante a gerência do Hotel, de escolher dois apartamentos em faces opostas (NE e SO) num mesmo andar, situados frente a frente e que pudessem utilizar um único equipamento, outros dois termopares extras, interligados pelo piso entre as UH durante os dias medidos.

Conforme está destacado na IL. 111, com a carta solar e no período medido, os apartamentos na face nordeste recebem sol até as 12:15 horas, enquanto que, na face sudoeste, o fazem a partir das 12:15 horas. O edifício caracteriza-se por não possuir nenhuma obstrução em nenhuma das faces, estando "faceado" na parte da caixa de elevadores com o Shopping Interlar, com um andar com pé-direito duplo.

$\mathrm{Na}$ pesquisa teve a liberdade para escolher quaisquer dois quartos em um andar recém reformado. Foram então definidas as UH 765 e 766 para este trabaIho, indicadas nas IL.112 e IL.113.

\subsection{Equipamentos utilizados na medição externa}

O posicionamento dos equipamentos de medição seguiu as recomendações da norma ISO 7726/98, e as medições externas ocorreram simultaneamente em três pontos, indicados na IL. 114. Outra medida, os dados climáticos da Estação 


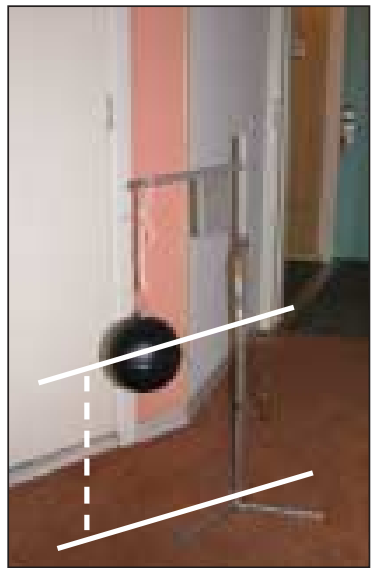

Ilustração 108: Termômetro e termopar dentro do globo suspensos por tripé.

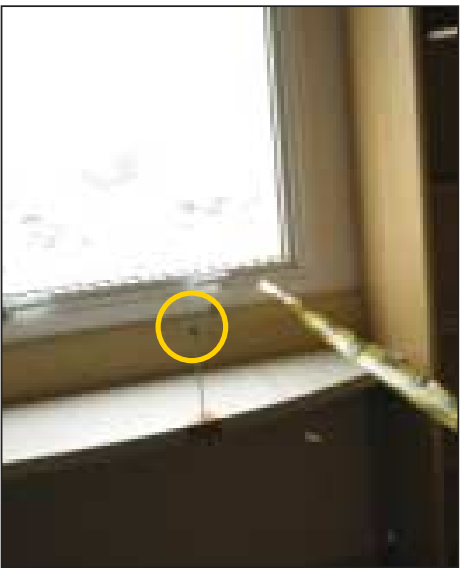

Ilustração 109: Termopar na sobre a bancada de trabalho da $\mathrm{UH}$ (indicado em amarelo).

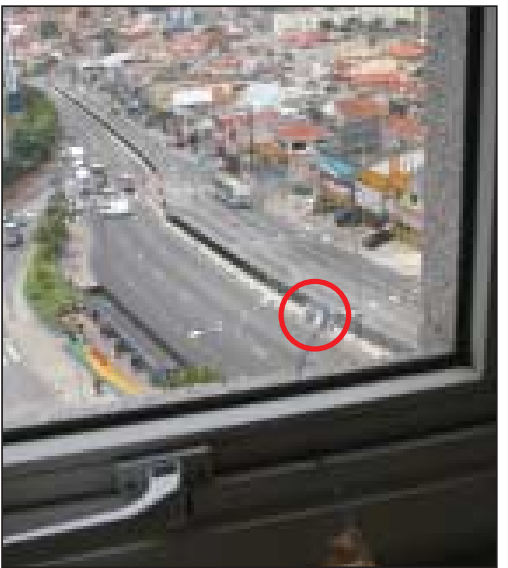

Ilustração 110: Termopar posicionado na parte externa da fachada (indicado em vermelho).

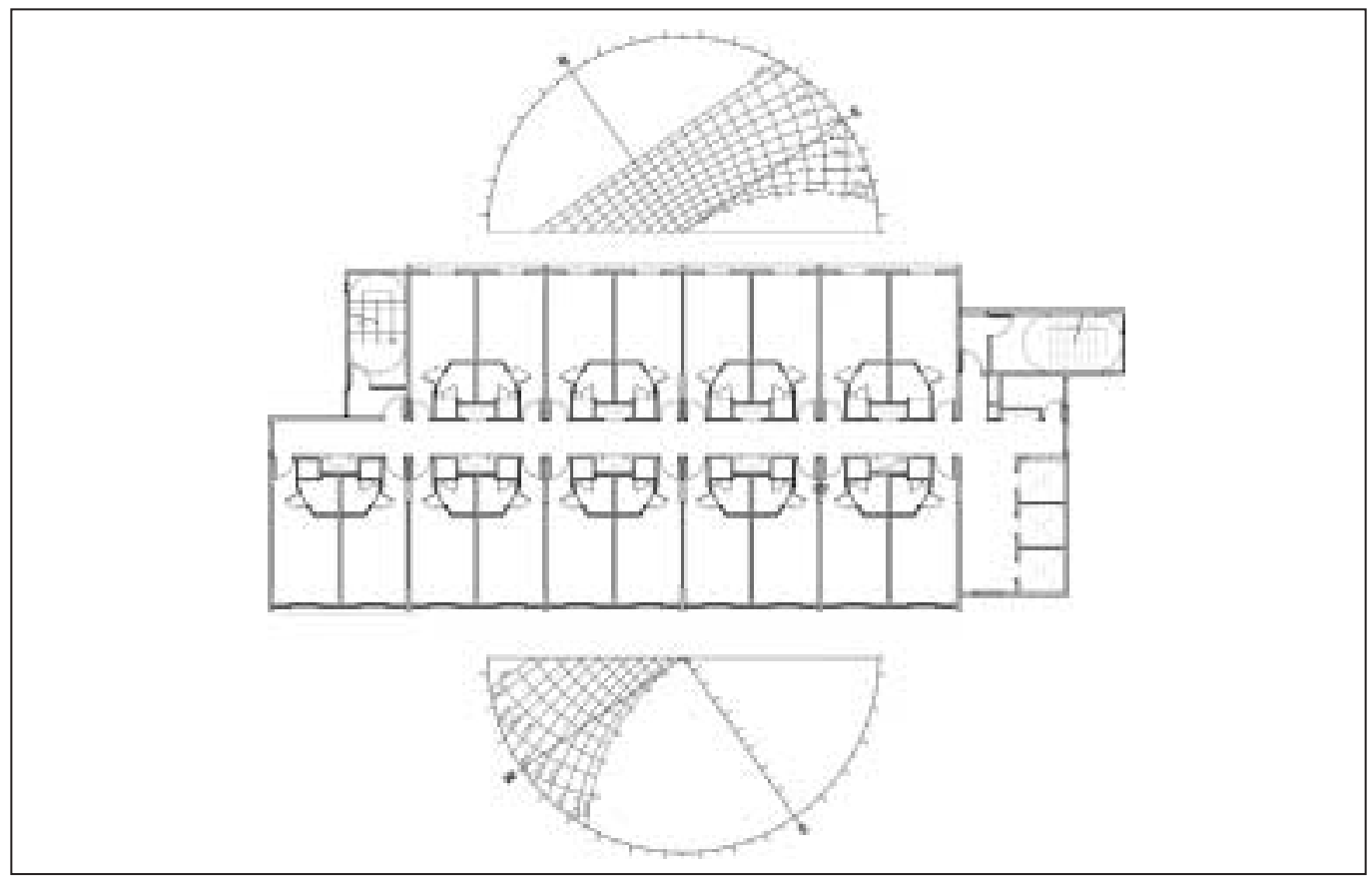

Ilustração 111: Planta do pavimento tipo com sobreposição da carta solar para verificação do período de insolação em cada face.

Meteorológica do IAG USP situada no Parque no Estado (ponto 3), também foram considerados como parâmetros nesta pesquisa. A descrição do posicionamento dos pontos na cidade é a seguinte:

PONTO 1: Na face externa do apartamento orientado a Sudoeste, com termopar protegido da radiação direta por meio de uma fita metalizada na ponta do sensor, conforme indicado na IL. 114. 


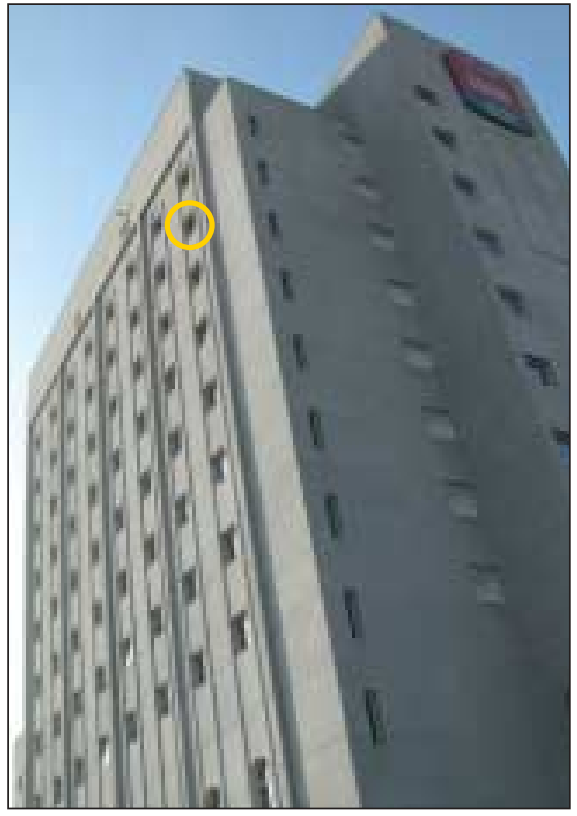

Ilustração 112: Indicação do apartamento 765 na fachada NE.

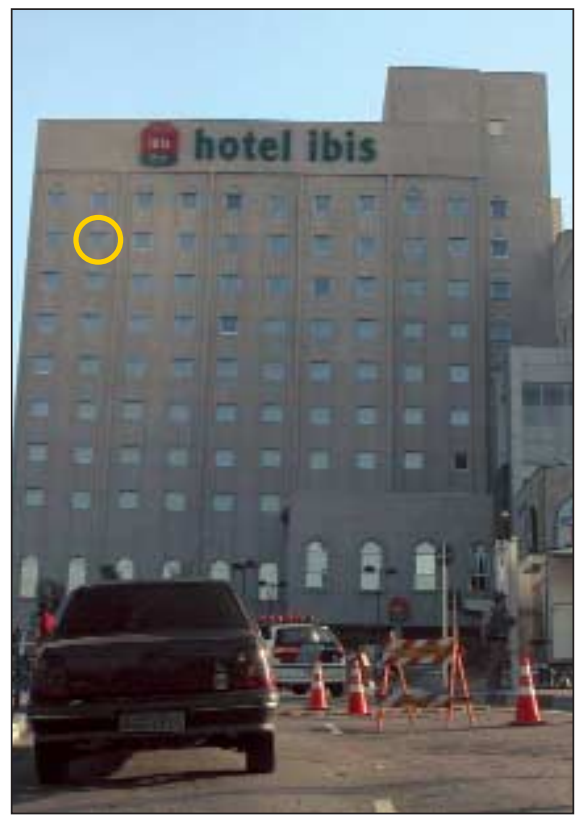

Ilustração 113: Indicação do apartamento 766 na fachada SO.

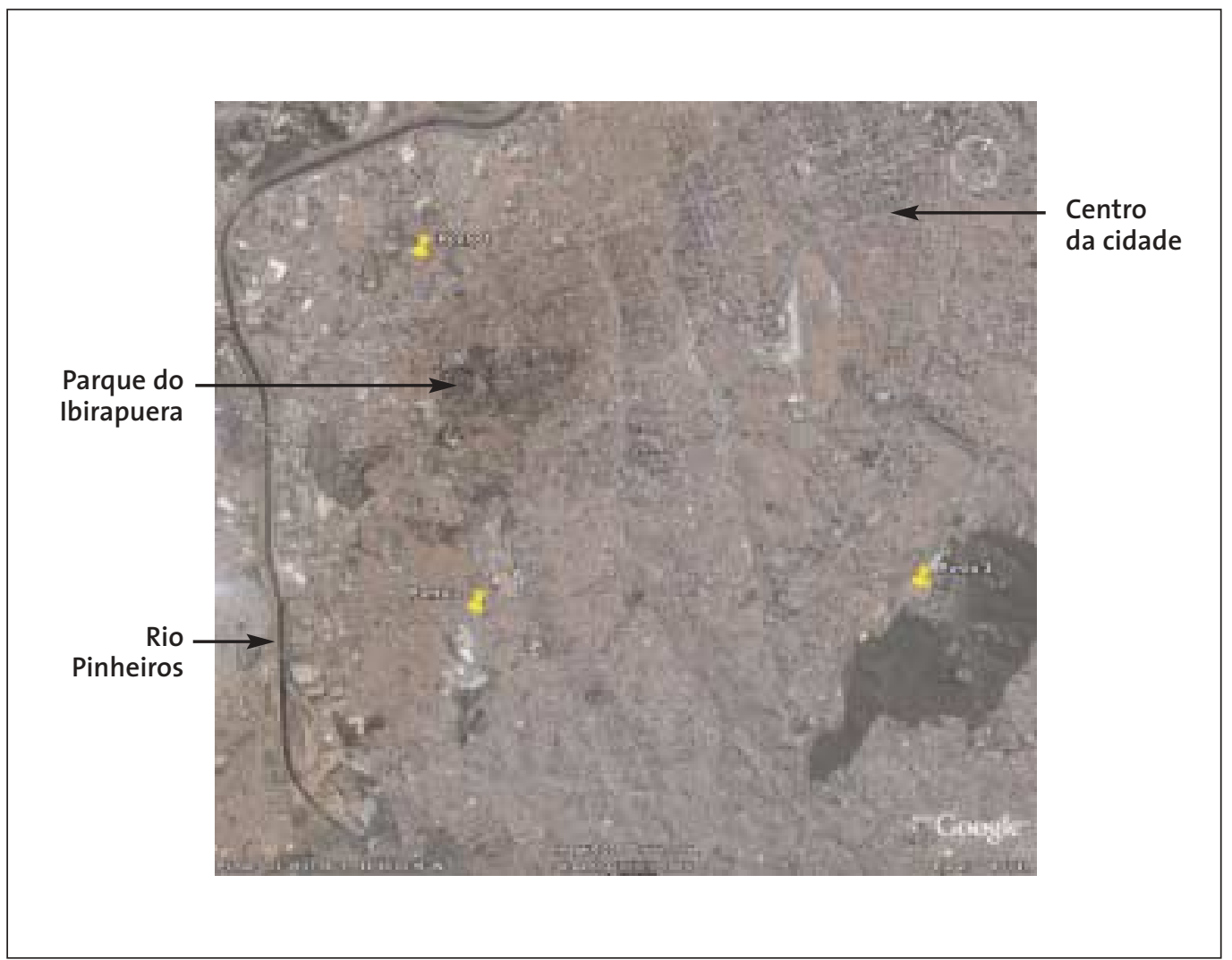

Ilustração 114: Localização dos três pontos (indicados em amarelo)

Fonte: Google Earth, 2007. 


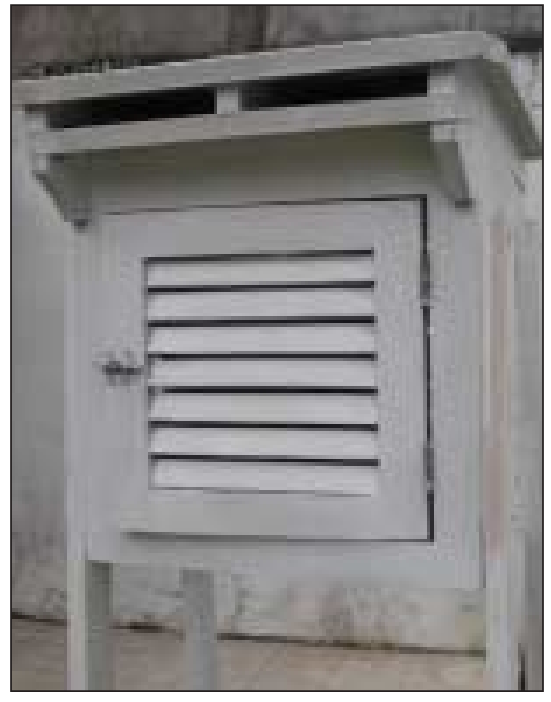

Ilustração 115: Abrigo meteorológico para proteção dos equipamentos ponto 2.

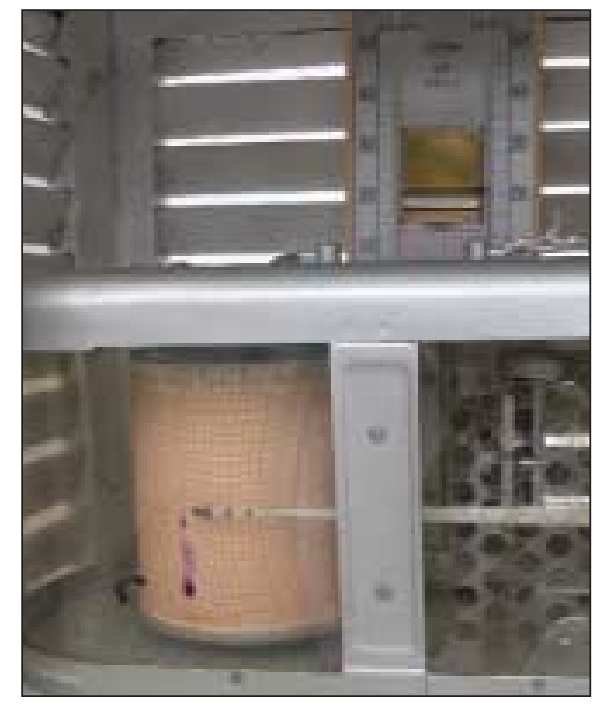

Ilustração 116: Equipamentos do ponto 2: Termômetro de bulbo seco e úmido, acima, e na frente, o termógrafo bimetálico.

PONTO 2: Na área externa de uma residência (situada a 4,2 km do hotel) localizada em jardim gramado, em bairro próximo e em zona residencial (indicado na IL. 114).

PONTO 3: Localizado no Parque do Estado (indicado na IL. 114).

A medição externa no ponto 1 foi feita pelo data logger Almemo, posicionado conforme indicado na IL. 115, no ponto 2, pelo termógrafo bimetálico e pelo termômetro de mercúrio, posicionados dentro de um abrigo meteorológico, conforme pode ser verificado na IL.116.

Os equipamentos com os quais foram feitas as medições externas, exceto o data logger Almemo (localizado na parte externa da janela da face NE), foram posicionados numa localidade mais próxima e segura, distando 4,2 km do edifício (distância do ponto 1 para o 2), em decorrência da falta de local com a segurança adequada necessária para a montagem do equipamento por longo período de medição.

Para averiguar os valores obtidos, foi instalado no ponto 2, no interior do abrigo meteorológico (conforme apresentado na IL.116), um termômetro de bulbo seco e bulbo úmido e um termógrafo Bimetálico.

A leitura dos dados de temperatura do termômetro foi feita ao longo do ciclo de medidas para a averiguação dos valores obtidos pelo termógrafo Bimetálico situado no mesmo local.

Do terceiro ponto, foram cedidos para a pesquisa os seguintes dados climáticos da Estação Meteorológica do IAG USP, medidos no mesmo período da pesquisa: 
- Temperatura de Bulbo Seco $\left({ }^{\circ} \mathrm{C}\right)$;

- Velocidade do ar (m/s);

- Umidade Relativa do Ar (\%);

- Insolação;

- Radiação Global;

- Temperatura do solo $\left({ }^{\circ} \mathrm{C}\right)$,

\section{Condições Internas}

Foram consideradas, nas condições internas, algumas variáveis definidas pelo Hotel, como o período medido (já que foram cedidos, sem custo para a aluna, dois apartamentos por seis dias consecutivos), e outras variáveis definidas pela aluna, com base em pesquisas na área e na disponibilidade das pessoas para participar como "hospede de controle" (Apêndice C).

Apesar de saber da dificuldade de geração da mesma carga interna, por se tratarem de dois ambientes distintos que deveriam ter uma carga interna mais próxima, buscou-se aproximar, da melhor forma, todas as variáveis que pudessem interferir na avaliação das características arquitetônicas, foco principal deste estudo.

\subsection{Período Medido}

O período de medição coincidiu com a disponibilidade do Hotel em ceder os dois apartamentos, por cinco dias consecutivos, com as condições climáticas favoráveis para a medição, além da disponibilidade de empréstimo dos equipamentos por parte do IPT e do LABAUT, utilizados nas medidas internas e externas.

A determinação do período de ocupação e da utilização dos equipamentos de televisão e luz geral do ambiente foram pré-definidas pela aluna e se basearam em pesquisas de Buoro et. all (2004) e Mesquita (2006). Nesses dois trabaIhos, foram realizadas Avaliações Pós-Ocupação (APO) com usuários de alguns hotéis econômicos em São Paulo. Entre as conclusões desses trabaIhos, está o fato de que a ocupação dos apartamentos ocorre apenas no período da noite em mais de $80 \%$ dos hóspedes, e que os apartamentos são utilizados para descanso (dormir), relaxamento (assistir televisão ou ler um livro) e higiene pessoal. 
No Apêndice B encontra-se o questionário elaborado para os ocupantes durante o período de medições, bem como os dados pré-estabelecidos de ocupação e utilização dos apartamentos.

\subsection{Seleção dos Ocupantes}

A utilização de hóspedes comuns do hotel durante a medição foi descartada desde o princípio, pois estes dificilmente seguiriam as normas de ocupação da pesquisa e poderiam interferir no posicionamento dos equipamentos e sensores. Assim, na seleção de duplas de ocupantes (uma para cada quarto), os chamados "hóspedes de controle", a aluna indicou as pessoas que desempenhariam essa função durante o período determinado, sendo eles indivíduos com características físicas parecidas (para que a carga metabólica também fosse similar), já que as medidas estavam sendo feitas nos dois apartamentos simultaneamente.

Segundo a norma ASHRAE Fundamentals, o metabolismo e a vestimenta são fatores primários que afetam o conforto; entre os fatores secundários estão sexo, altura, idade, peso (determinantes no metabolismo de cada pessoa). Sabe-se que o conforto é subjetivo e varia de pessoa a pessoa. Mesmo assim, nesta pesquisa, buscaram-se pessoas com alguma proximidade dos fatores descritos anteriormente, pois os apartamentos seriam medidos simultaneamente. Os "hóspedes de controle" estão apresentados no Apêndice C, com as variáveis de vestimenta (clo), fator primário segundo a ASHRAE Fundamentals, no momento da chegada no hotel, bem como com a vestimenta para dormir.

\subsection{Variáveis pessoais (vestimenta e atividade)}

As características da ocupação que, segundo FANGER, são determinantes para verificar se os usuários estão em conforto são: o metabolismo, que sofre influência da atividade exercida no ambiente, e o clo. Neste trabalho, elas foram consideradas no questionário, já que o ambiente em questão é de uso privativo.

Cada "hóspede de controle" registrou o período de banho e troca de roupa. No entanto, no período de metabolismo basal, não é possível saber se o usuário sentiu frio (cobrindo-se com lençol ou cobertor) ou calor (não utilizando nenhuma coberta). 


\subsection{Ganhos de calor internos pela iluminação e pelos equipamentos}

O sistema de iluminação na UH compreende luminárias dirigidas nas cabeceiras da cama, a iluminação geral do ambiente. Todas as luminárias existentes estão listadas na TAB 19.

Sabe-se que o acionamento do sistema de iluminação e equipamentos é feito por cada hóspede e, portanto, o manual elaborado pela aluna considerou um período pré-determinado de uso, levando em conta a avaliação do impacto desses ganhos de calor para cada um. Da mesma forma, foram levantados os consumos desagregados dos equipamentos listados na TAB. 20, que determinam outro item nos ganhos de calor pelos.

Tanto o período de uso da televisão, quanto o do acionamento das lâmpadas na UH foram controlados durante a medição pelos usuários e acrescidos na avaliação final dos resultados.

\section{Os índices de conforto adotados}

As características dos Hotéis econômicos que, em sua maioria, utilizam-se do sistema de $\operatorname{Ar}$ Condicionado (SAC) e da ventilação natural para a obtenção de conforto, implica na escolha de um índice que atenda às duas situações

A norma ASHRAE 55/1992 - Thermal Envirnomental Conditions fot Human Occupancy -, refere apenas a ambientes condicionados artificialmente. No entanto, a norma ASHRAE 55/2004, recentemente revisada, incorporou pesquisas relevantes, tais como a de De DEAR, BRAGER e COOPER (1997), que incluiu o método de calculo do Voto Médio Estimado (VME) e Percentual de Pessoas Insatisfeitas (PPI) e o conceito do modelo adaptativo.

Para a pesquisa em questão, dois elementos são fundamentais na compreensão das variáveis dos índices de conforto térmico, no caso de hotéis. A primeira seria o metabolismo que, para este estudo foi, na maior parte do período, basal e igual a o,7 (referente à pessoa dormindo). A segunda seria a variação da vestimenta/coberta, cujo impacto interfere na sensação de conforto, por se tratar de um ambiente de uso privativo no qual o usuário tem total liberdade de alterá-la.

Conforme foi apresentado na seção 4.5, o índice de conforto térmico adotado na avaliação do estudo de caso foi baseado na Norma ASHRAE 55 (2004). 


\begin{tabular}{|lcccc|}
\hline \multicolumn{4}{|c|}{ TABELA 19: SISTEMA DE ILUMINAÇÃO ARTIFICIAL DA UH } \\
\hline & Luminárias & Lâmpadas & Modelo & Cor da luz \\
\hline Geral & 2 & 1 & Dicróica & amarela \\
\hline Dirigida & 2 & 2 & PL-C 26W & cor branca \\
\hline
\end{tabular}

\begin{tabular}{|lcccc|}
\hline \multicolumn{5}{|c|}{ TABELA 20: EQUIPAMENTOS EXISTENTES NA UH } \\
\hline & Potência & Ligada & Desligada & Período \\
\hline TV 21 polegadas & $72 \mathrm{~W}$ & $20: 10$ & $23: 30$ & $3: 20 \mathrm{hs}$ \\
\hline Frigobar Cônsul & $70 \mathrm{~W}$ & $0,6 \mathrm{~A}$ & $8 \mathrm{hs}$ \\
\hline
\end{tabular}

\section{Análise dos dados medidos}

A análise dos dados ocorreu em cinco etapas:

$1^{\text {a }}$ etapa: Avaliação preliminar dos dados medidos com os equipamentos posicionados no interior das UH e posterior escolha do dia mais representativo para a análise.

$2^{\text {a }}$ etapa: Tratamento dos dados climáticos da Estação Meteorológica do IAG USP.

$3^{\text {a }}$ etapa: Comparação dos resultados das medições de temperatura externa (sensor externo do data logger Almemo, termógrafo bimetálico, termômetro de mercúrio e Estação Meteorológica do IAG USP) para a definição dos valores mais adequados para serem considerados na avaliação.

$4^{\text {a }}$ etapa: Cálculo da temperatura radiante média (TRM), e comparação dos resultados obtidos nos dois a partamentos.

$5^{a}$ etapa: Análise geral das medições para o dia determinado na primeira etapa. 


\subsection{Avaliação preliminar dos dados medidos na UH $-1^{\text {a }}$ etapa}

Os dados foram medidos em cinco dias consecutivos, sendo os três últimos deles também com geração de carga interna, devido a ocupação dos "hospedes de controle" (na IL. 117). O data logger Almemo AFHA646 ficou instalado durante cinco dias com seis termopares distribuídos, conforme indicado na IL.106. Destes, um estava medindo a temperatura no exterior da janela e o restante no interior das UH.

Verificou-se que as temperaturas externas máximas diárias foram aumentando sucessivamente, dia após dia, chegando a uma amplitude de até $18{ }^{\circ} \mathrm{C}$, enquanto que, internamente, a amplitude foi menor do que $20^{\circ} \mathrm{C}$, uma diferença considerável, já que as janelas permaneciam fechadas, constatando-se, portanto, alta inércia da envoltória.

Para um mesmo, período a temperatura externa máxima chegou a quase oito graus Celsius, superior às temperaturas internas medidas nas duas UH (SO e $N E)$. No entanto, nesse mesmo período, em ambas a variação a temperatura interna foi de, no máximo, 2 graus Celsius.

Notou-se que há uma pequena diferença na temperatura interna, devido à diferença na orientação, e que as alterações de temperaturas externas não refletem, em curto prazo, alterações na temperatura interna. A inércia da envoltória determina este atraso.

Sendo assim, definiu-se que o último dia em que ocorreram as medidas (dia três da II.117) seria o mais representativo para a análise completa dos resultados, realizada posteriormente.

\subsection{Tratamento dos dados climáticos da Estação Meteorológica do IAG USP $-2^{\mathrm{a}}$ etapa}

Os dados fornecidos pela Estação meteorológica do IAG USP foram tratados de modo a compor um arquivo climático que seria utilizado, posteriormente, em simulações para a calibração da avaliação paramétrica. Foram levantados:

- Temperatura de bulbo seco $\left({ }^{\circ} \mathrm{C}\right)$;

- Velocidade do ar (m/s);

- Umidade relativa do ar (\%);

- Insolação;

- Radiação global (MJ/m²);

- Nebulosidade. 


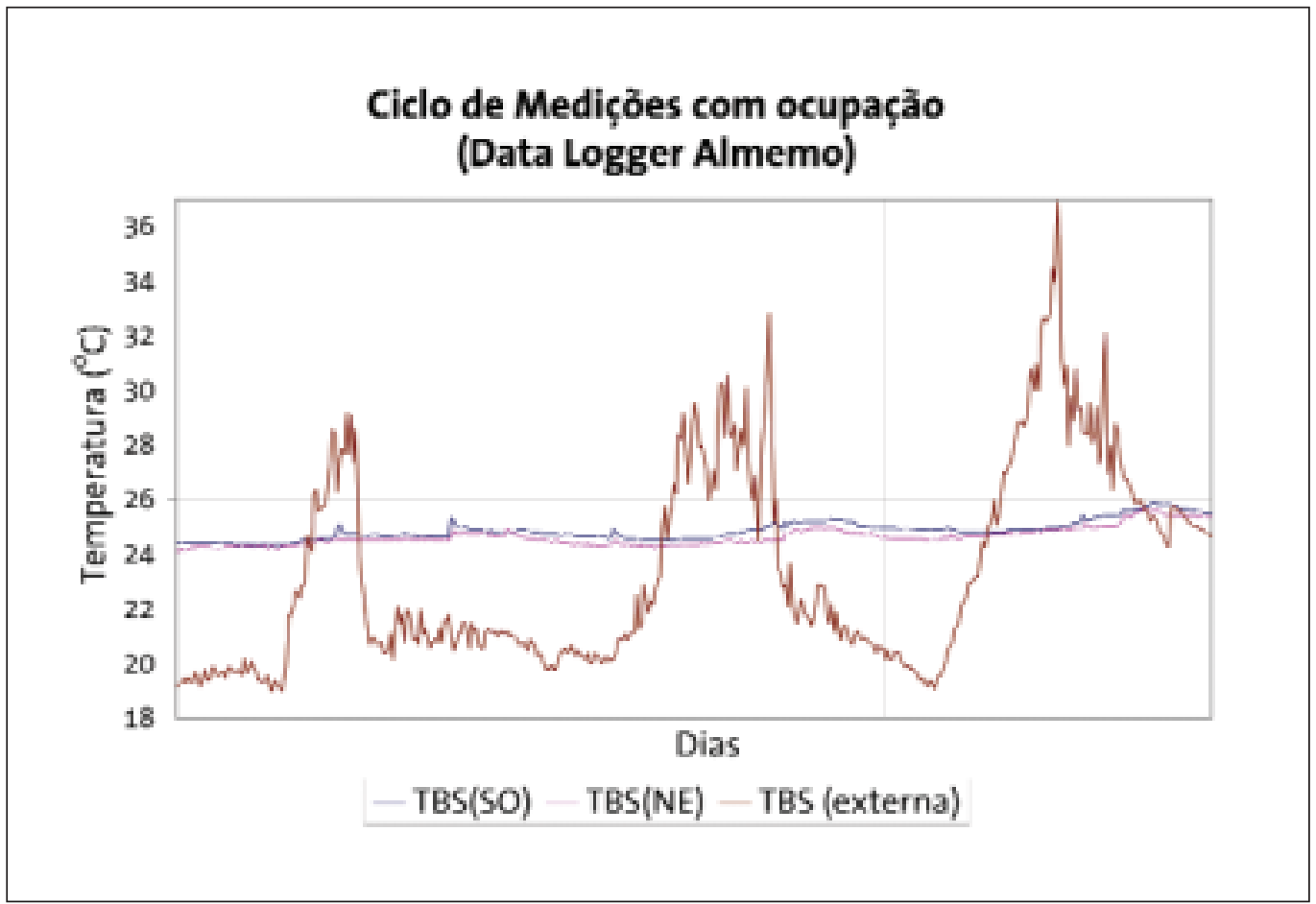

Ilustração 117: Ciclo de medições realizado com data logger Almemo dos três dias em que foram considerados com geração de carga interna nas $\mathrm{UH}$.

No tratamento dos dados foi calculada a parcela difusa da radiação com base no método apresentado por Duffie\& Beckman (1980, apud BRANDÃO,2004, p. 49), e consta a seguir:

$$
\begin{array}{lll}
G_{d}=G_{g} *\left(1,0-0,249^{*} k_{t}\right) & \text { para } k_{t}<0,35 & \text { Equação 1 } \\
G_{d}=G_{g} *\left(1,557-1,84^{*} k_{t}\right) & \text { para } 0,35<k_{t}<0,75 & \text { Equação 2 } \\
G_{d}=0,177 G_{g} & \text { para } k_{t}<0,75 & \text { Equação 3 }
\end{array}
$$

Sendo que:

$G_{d}=$ radiação global diária

$\mathrm{G}_{\mathrm{g}}=$ Radiação difusa

$k_{t}=$ irradiação diária no topo da atmosfera

O dado de vento fornecido pela estação foi corrigido para a altura equivalente do eixo da janela do andar em que foram feitas as medidas internas $(\mathrm{H}=$ $27.88 \mathrm{~m}$ ). Com isso, a correção da velocidade do vento foi feita com o seguinte cálculo (BUILDING RESEARCH ESTABISHMENT, 1978), cuja equação está apresentada a seguir: 
$v=v_{m} \cdot k \cdot z^{a}$

Equação 4

Sendo:

$\mathrm{v}=$ velocidade do vento na altura $\mathrm{z}$;

$v_{m}=$ velocidade do vento na estação meteorológica (10m);

$z$ = altura de referência;

$k,{ }^{a}=$ coeficientes de terreno

Foram adotados, como coeficiente de terreno, os seguintes valores: 0,35 para k, e 0,25, segundo os coeficientes do terreno para áreas urbanas, apresentados pó Bittencourt e Cândido (2005).

\subsection{Comparação dos resultados das medições de temperatura externa $-3^{\mathrm{a}}$ etapa}

Conforme foi descrito anteriormente, as medições externas ocorreram com quatro equipamentos diferentes, sendo que um deles, o Data Logger Almemo (situado a $10 \mathrm{~cm}$ da janela), era o mesmo equipamento utilizado nas medições internas (com acurácia de $0,3^{\circ} \mathrm{C}$ ).

Os valores obtidos do termômetro de mercúrio foram comparados simultaneamente, no período de medição, com os resultados obtidos nas medições tanto do Termógrafo Bimetálico quanto dos valores obtidos com a estação meteorológica do IAG USP.

Dessa forma, foram comparados os valores de TBS obtidos, que estão indicados (IL.118).

O Termógrafo Bimetálico foi calibrado com o termômetro de mercúrio e a leitura dos seus dados por ser visual proveniente da impressão em papel, os valores foram plotados em escala temporal maior do que dos outros dois (a cada 30 minutos). Por isto, a curva de leitura do termógrafo foi ajustada pela média móvel dos valores lidos pela autora, e estão indicadas com a linha magenta.

Os valores medidos no data logger Almemo estão indicados na figura em amarelo, e o posicionamento do sensor na fachada externa da janela (apresentado anteriormente, na IL.106) registra os valores a cada dez minutos.

Nota-se que as maiores diferenças ocorreram nos períodos com as menores temperaturas. Nas maiores temperaturas, provenientes do data logger, pode-se verificar variações com a outra leitura, principalmente no período da tarde. Apesar da proteção deste sensor, os valores de leitura do equipamento sofreram interferência da emissão de calor pela envoltória, e por este motivo as leituras 


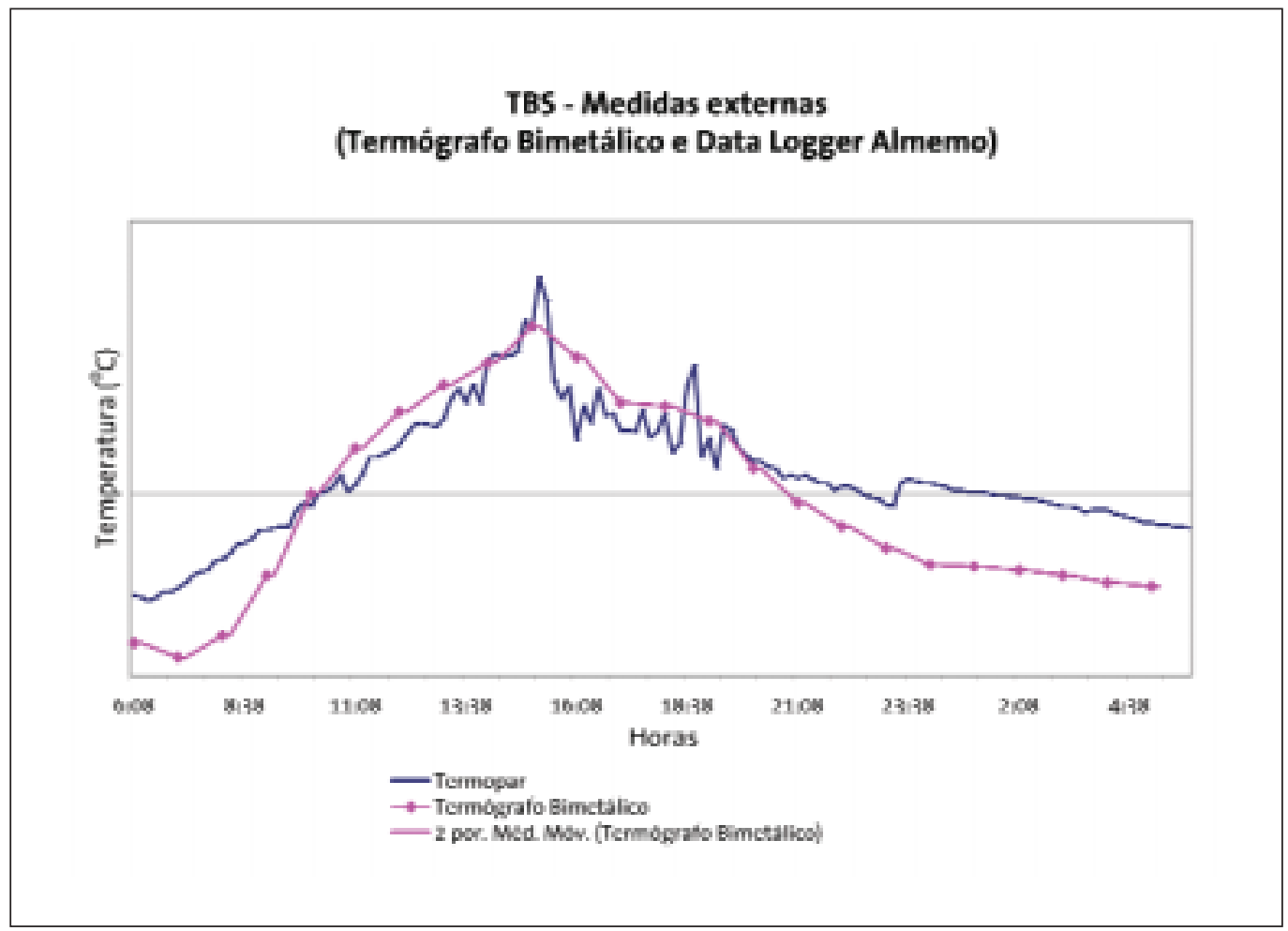

Ilustração 118: Comparação das medições externas realizadas em diferentes equipamentos (Termógrafo Bimetálico, data Logger Almemo).

com as temperaturas mais baixas foram maiores: o calor absorvido pela envoltória durante o dia foi re-transmitido no final do dia e o sensor próximo na fachada apresentou-se sensível a esta diferença.

Para confirmação desta conclusão, foram solicitados os dados climáticos da estação meteorológica do IAG, que foram comparados na IL.119. A estação meteorológica acompanha, numa mesma variação de curva as medidas da estação meteorológica do IAG USP.

Para esta pesquisa foram considerados como mais adequados os valores obtidos nas medidas provenientes da Estação Meteorológica.

\subsection{Cálculo da temperatura radiante média ( $4^{\mathrm{a}}$ etapa)}

A temperatura de globo foi medida utilizando-se um termopar posicionado no centro de um globo negro, a $60 \mathrm{~cm}$ do piso, como apresentado na Ilustração . O posicionamento dos sensores e dos globos nos ambientes foi definido de forma que a circulação de ar entre o globo e os sensores não interferisse na leitura dos valores obtidos. Ambos os conjuntos foram colocados na mesma posição, relativa- 


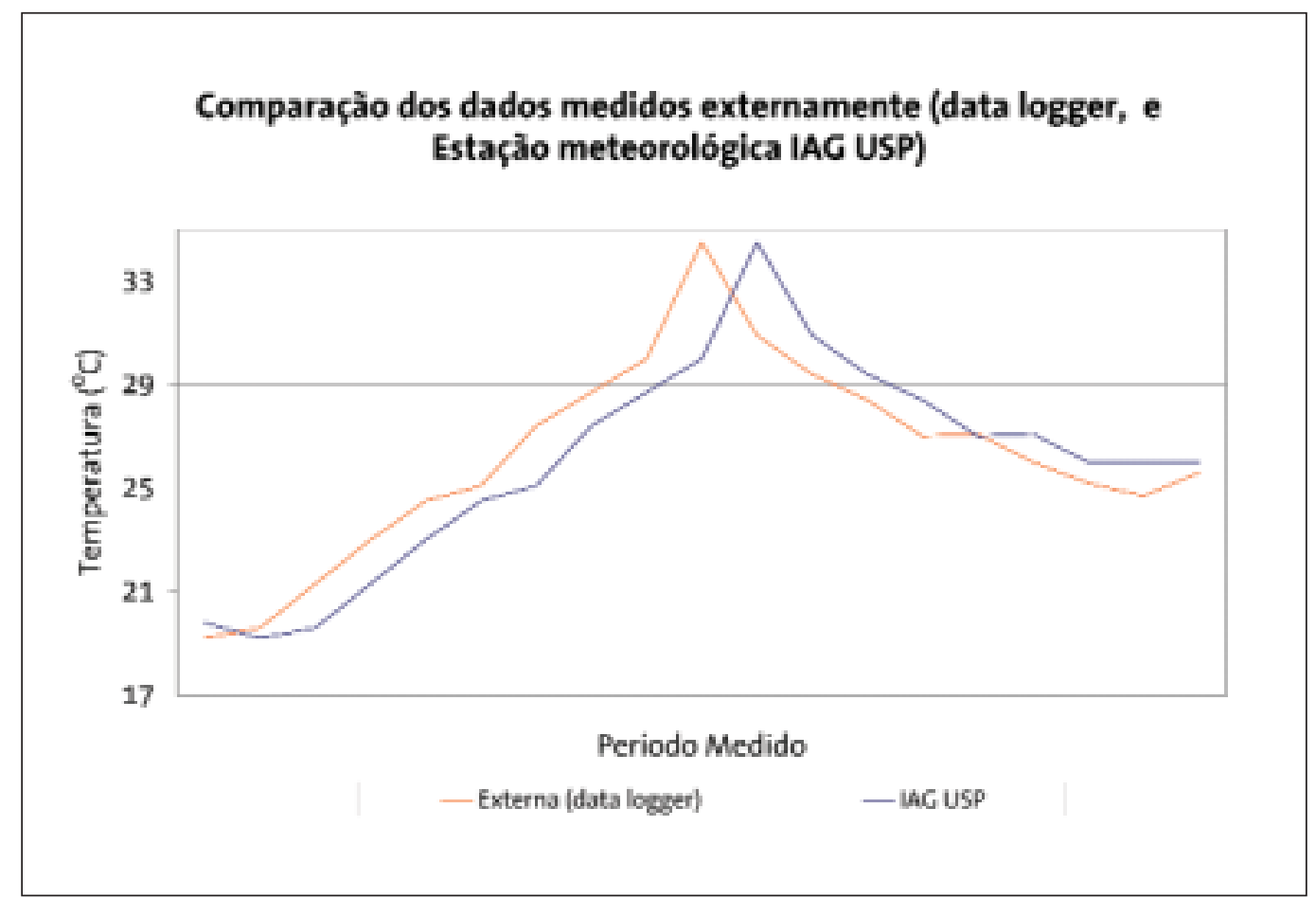

Ilustração 119: Comparação das medições externas realizadas em diferentes equipamentos (Data Logger Almemo , no ponto 1, e estação meteorológica IAG, no ponto 3).

mente aos seus ambientes. Os resultados medidos encontram-se na IL.12O.

Com as temperaturas de globo medidas, e através do balanço térmico, seguindo as equações determinadas pela norma ISO 7726/98, calculou-se a temperatura média radiante, segundo a equação 5:

$$
t_{r}=\left[\left(t_{g}+273\right)^{4}+2,5 \cdot 109 \cdot v_{a}^{0,6}\left(t_{g}-t_{a}\right)\right]^{1 / 4}-273
$$

sendo:

$t_{r}$ - temperatura média radiante $(T R M)$ em ${ }^{\circ} \mathrm{C}$

$\mathrm{t}_{\mathrm{g}}$ - temperatura de globo em ${ }^{\circ} \mathrm{C}$

$\mathrm{t}_{\mathrm{a}}$ - temperatura do ar em ${ }^{\circ} \mathrm{C}$

$v_{a}$ - velocidade do ar em $\mathrm{m} / \mathrm{s}$

A equação é válida apenas para um globo padrão e para ventilação forçada, que é o caso em questão. Nos parâmetros considerados para o cálculo da TRM, além dos valores medidos, considerou-se $0,15 \mathrm{~m} / \mathrm{s}$ a velocidade do ar.

Segundo a definição da ASHRAE (2005), TRM é uma temperatura uniforme de um ambiente fechado imaginário, no qual a transferência de calor imaginável 


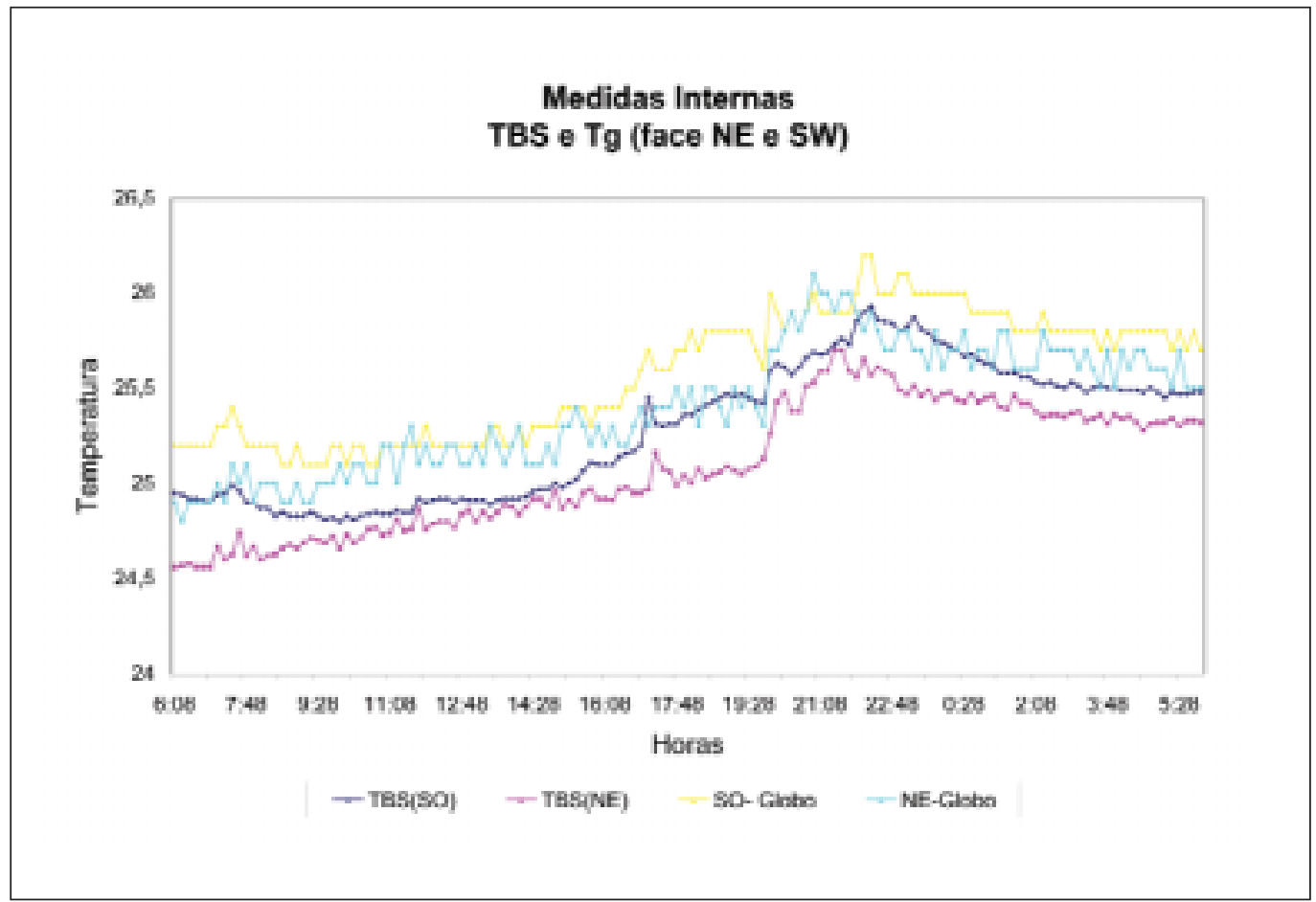

Ilustração 120: Medidas internas: temperatura do ar (TBS) e temperatura de globo (Tg).

do corpo humano iguala-se à transferência de calor no ambiente atual, não uniforme. Sendo assim, a TRM é a resultante da interação das temperaturas das diversas superfícies que delimitam o recinto (paredes, piso, teto). Idealmente, para as condições climáticas do verão de São Paulo, a TRM não deve ser superior à temperatura do ar e, no inverno, ela não deve ser inferior.

Na IL.121, foram comparados os valores obtidos internamente com o data logger Almemo e a medida externa do Termógrafo Bimetálico e os dados da estação meteorológica do IAG USP. O fundo em lilás representa o período no qual o quarto foi ocupado pelos hóspedes de controle.

Verificou-se que houve uma variação interna de temperatura do ar muito pequena em relação à externa e que a ocupação não tem impacto praticamente nenhum no aumento da carga térmica. A variação da temperatura do ar interna foi menor do que $1{ }^{\circ} \mathrm{C}$, sendo os valores obtidos ainda dentro dos limites aceitáveis da zona de conforto.

Nota-se também que, apesar da diferença da orientação das duas UH, a diferença de temperatura do ar interno entre elas é quase desprezível, provavelmente devido às características da envoltória. 


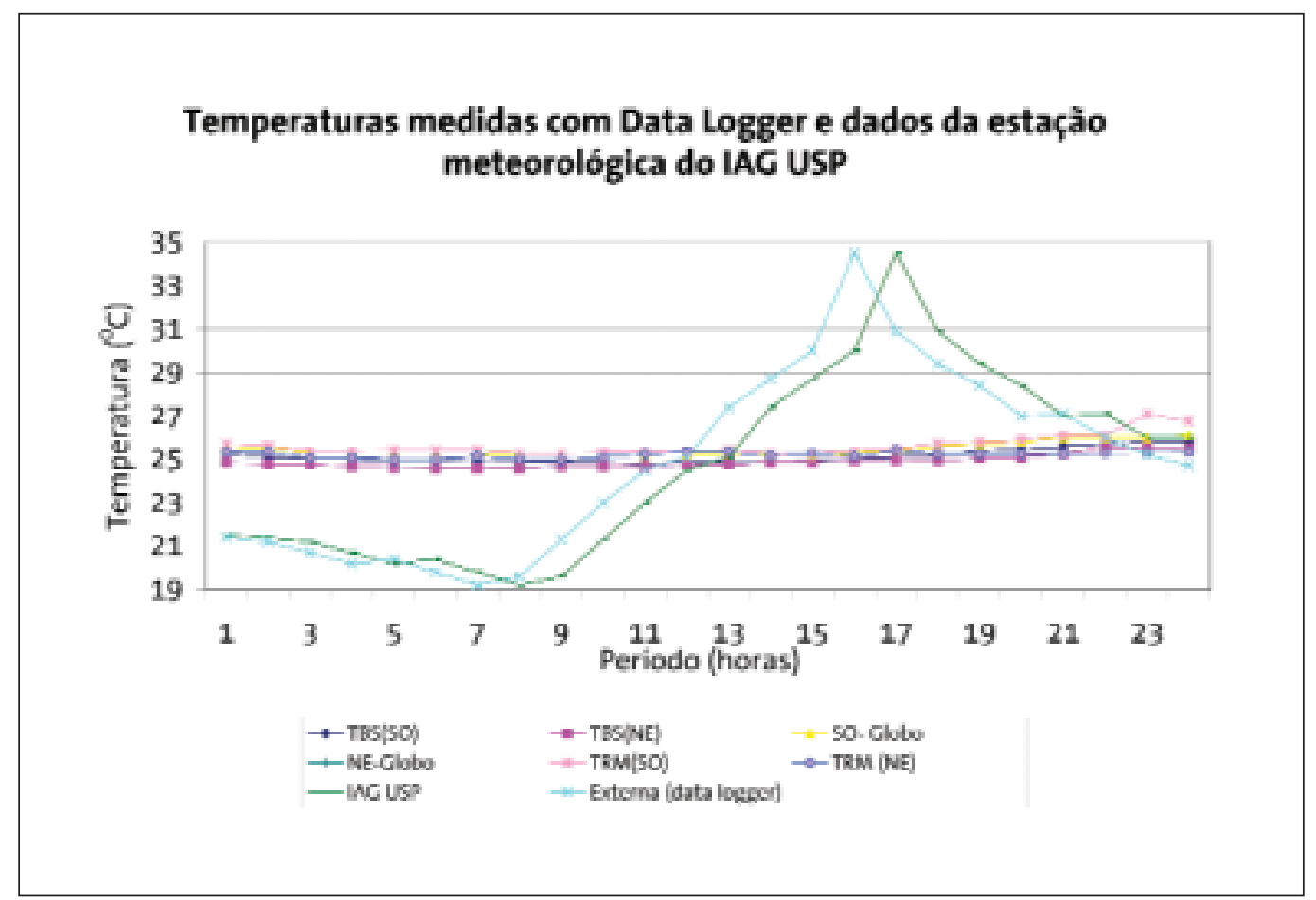

Ilustração 121: Medidas internas e externas (com data logger Almemo e estação meteorológica IAG).

\subsection{Análise geral das medições ( $5^{\mathrm{a}}$ etapa)}

A análise geral foi realizada em três etapas, enumeradas a seguir:

- Avaliação das medidas realizadas

- Avaliação da arquitetura do apartamento (sistema construtivo e materiais) e resposta dos "hóspedes de controle".

- Avaliação do índice de conforto e do arquivo climático

Inicialmente foi analisada a TRM nas duas fachadas, considerando-se o período de ocupação e os equipamentos que foram acionados. Numa segunda análise, foram levantadas as características e os materiais das UH, para que, na etapa seguinte, fossem comparadas com a temperatura média do mês, de acordo com o arquivo climático (De Benedetto, 2007).

\subsubsection{Avaliação das medidas realizadas}

$\mathrm{Na}$ IL. 122, verifica-se que a TRM sofre pequena variação até as 14 h e, a partir daí, aumenta gradativamente, chegando ao seu pico às $21 \mathrm{~h}$ na face Nordeste e 22:30 h na face Sudoeste.

De acordo com o questionário e a listagem de controle de acionamento de lâmpadas e equipamentos, verifica-se que o pequeno aumento das temperaturas 


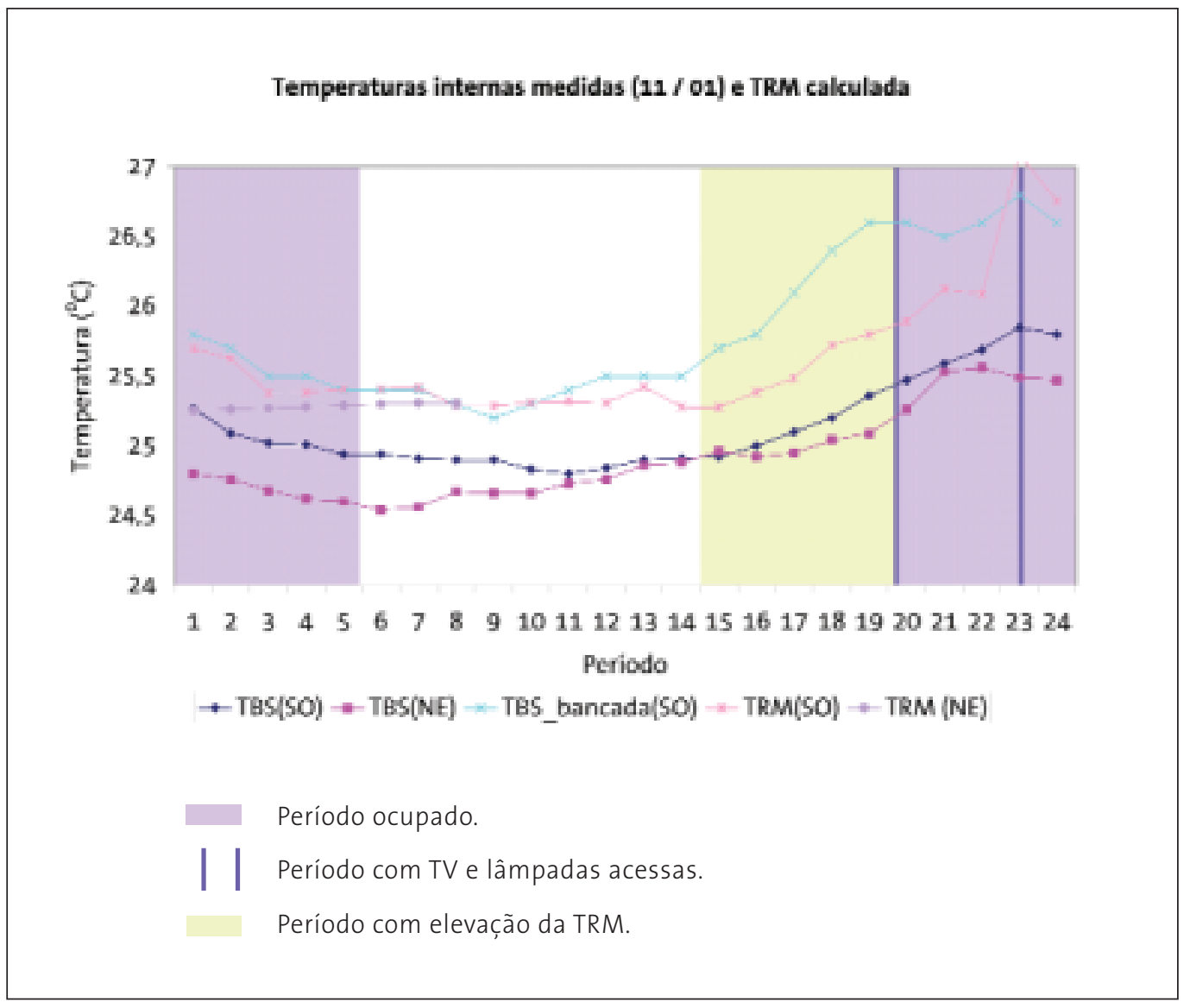

Ilustração 122: Temperaturas internas medidas no dia 11/1com valores de TBS e TRM nas faces SO e $\mathrm{NE}$, com indicação do período de ocupação e acionamento de equipamentos e lâmpadas.

não ocorre durante o período de ocupação, mas a partir das 14:00 horas, nos dois apartamentos.

A diferença de temperatura é muito pequena entre os apartamentos pouco menos do que meio grau -, variando de acordo com o período do dia. Essa variação já está considerada na margem de erro do equipamento e, portanto, entende-se que são muito próximas, pode-se mesmo dizer equivalentes.

Os ganhos de calor internos devido à ocupação, iluminação e equipamentos é muito pequeno em relação ao volume do ambiente. Comparando-se os valores de TBS e TG das medidas realizadas internamente no centro do apartamento da face Sudoeste e na bancada, com os valores obtidos na medida externa com o Termógrafo Bimetálico (IL. 123), verifica-se que o valor medido na bancada é um pouco superior ao valor do centro do apartamento. Isso ocorre devido à influência da TRM da cortina que, apesar de estar fechada no período medido, recebia a radiação através do vidro da janela, fato que se refletiu no aumento da temperatura medida no ponto da bancada, a partir das $16 \mathrm{hs}$, aproximadamente. 


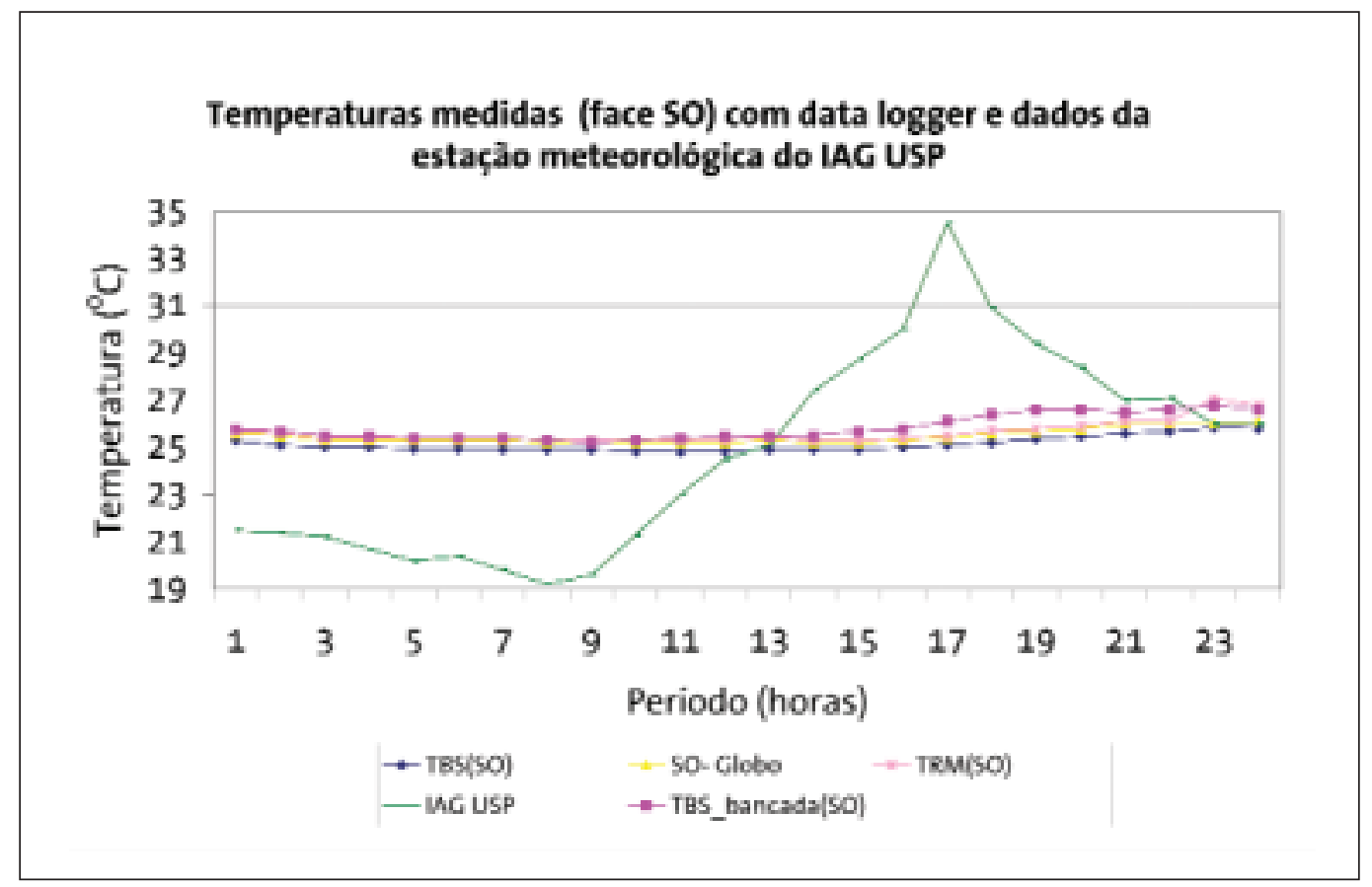

Ilustração 123: Comparação das medidas internas (face SO) no centro do quarto e na bancada com a medida externa da Estação Meteorológica IAG USP.

A elevada temperatura externa influencia pouco no aumento da temperatura da medida da TBS da bancada, feita a $20 \mathrm{~cm}$ do vidro. As explicações poderiam vir da existência de um vão de abertura do quarto com fechamento em vidro de fator solar baixo, além da cortina espessa (modelo backout), com grande capacidade de barrar parte da radiação incidente, ou seja, fator solar estimado de 0,35.

\subsubsection{Avaliação das arquitetura do apartamento (materiais)}

Com os resultados observados nas medidas, foram posteriormente analisadas a características dos materiais das UH. A intenção desta etapa da avaliação foi verificar como o isolamento da fachada auxilia na inércia constatada nas medições e como a composição do vidro, além do seu WWR (coeficiente que exprime a relação entre superfícies opacas e transparentes de uma fachada) podem ter sido favoráveis ou não para as condições de conforto.

A combinação de todos esses elementos é fator determinante para o reduzido ganho de calor nos edifícios dessa tipologia e para a melhoria do desempenho do edifício. Os componentes construtivos externos do apartamento constam da na TAB. 21.

A listagem dos componentes construtivos internos do apartamento constam da na TAB. 22. 


\begin{tabular}{|c|c|c|}
\hline & Ambiente & Material \\
\hline 6 & $\begin{array}{l}\text { UH - corredor } \\
\text { acabamento bilateral }\end{array}$ & $\begin{array}{l}\text { Bloco de concreto } \\
\text { Gesso } \\
\text { Pintura }\end{array}$ \\
\hline 7 & UH - banheiro & Bloco de concreto \\
\hline 8 & $\begin{array}{l}\text { Banheiro } \\
\text { acabamento bilateral }\end{array}$ & $\begin{array}{l}\text { Argamassa } \\
\text { Reboco } \\
\text { Cerâmica }\end{array}$ \\
\hline 9 & Piso & Carpete \\
\hline 10 & Porta & $\begin{array}{l}\text { Madeira } \\
\text { Isolamento acústico }\end{array}$ \\
\hline 11 & $\begin{array}{l}\text { Vidro - externo } \\
\text { Laminado }\end{array}$ & $\begin{array}{l}\text { Refletivo prata } \\
\text { Polivinil butiral incolor (PVB) }\end{array}$ \\
\hline & wwr & Polivini butiral \\
\hline 13 & Caixilho & PVC branco \\
\hline
\end{tabular}

Fonte:STR - Valor do fabricante AFG para o vidro Float reflexivo série -S. Disponivel em:

〈http://Www.usp.br/fau/deptecnologia/docs/bancovidros/vfabr.htm> Acesso em 28 Mai. 2007.

\begin{tabular}{|c|c|c|}
\hline & Ambiente & Material \\
\hline 1 & Acabamento interno & $\begin{array}{l}\text { Bloco de concreto } \\
\text { Gesso } \\
\text { Pintura }\end{array}$ \\
\hline 2 & Acabamento externo & $\begin{array}{l}\text { Argamassa } \\
\text { Reboco } \\
\text { Cerâmica }\end{array}$ \\
\hline 3 & Acabamento externo & Argamassa texturizada \\
\hline 5 & Laje & \\
\hline
\end{tabular}


Contatou-se que a composição dos materiais das UH resulta em inércia elevada. Além dela, a composição do vidro (refletivo prata, com fator solar, STR, estimado de 0,35) e do wwr reduzido (de 0,23) diminuem o provável ganho pelo componente translúcido, o caixilho. O vidro com fator solar (STR) de 0,35 representa que $35 \%$.da radiação que incide nele é transformada em calor

A composição do vidro, seu fator solar, dadas as dimensões das UH, e a porcentagem de área exposta é um fator importante a ser entendido nesta etapa da avaliação. Conforme foi apresentado na seção 4.8.1, a transmissão de calor da radiação solar pelas superfícies transparentes ocorre tanto pela radiação direta, incidente sobre o vidro, quanto pela transmissão indireta proveniente do calor que, após ser absorvido pelo vidro, é retransmitido para o ambiente interno.

\subsubsection{Avaliação do índice de conforto e de arquivo climático (Fonte: IAG - USP)}

Considerando os valores medidos internamente nas duas faces (NE e SO), foi verificado se os valores internos, apesar das janelas fechadas e SAC desligado, estariam dentro dos limites de conforto determinados pela norma ASHRAE 55 (2004), tal como aparece na IL.124.

Observa-se que os valores estão dentro da faixa de conforto determinados pelo modelos da ASHRAE 55, mais do que no modelo de Humphreys (que aceita limites de temperaturas mais baixas).

\section{Conclusões}

Os ganhos de calor internos são tão pequenos que não interferem nas condições de conforto e desconforto dos apartamentos. A TRM está muito próxima da temperatura do ar (TBS), demonstrando que não há interferência significativa das superfícies nos ganhos de calor internos.

O edifício possui características construtivas que determinaram uma inércia alta e, com isso, as respostas da edificação às variáveis externas são lentas, auxiliando na melhoria das condições de conforto térmico dos apartamentos condicionados naturalmente.

Apesar das medições terem ocorrido no período do verão, recomenda-se que, nos dias mais frios do ano, os apartamentos sejam mantidos com as cortinas 


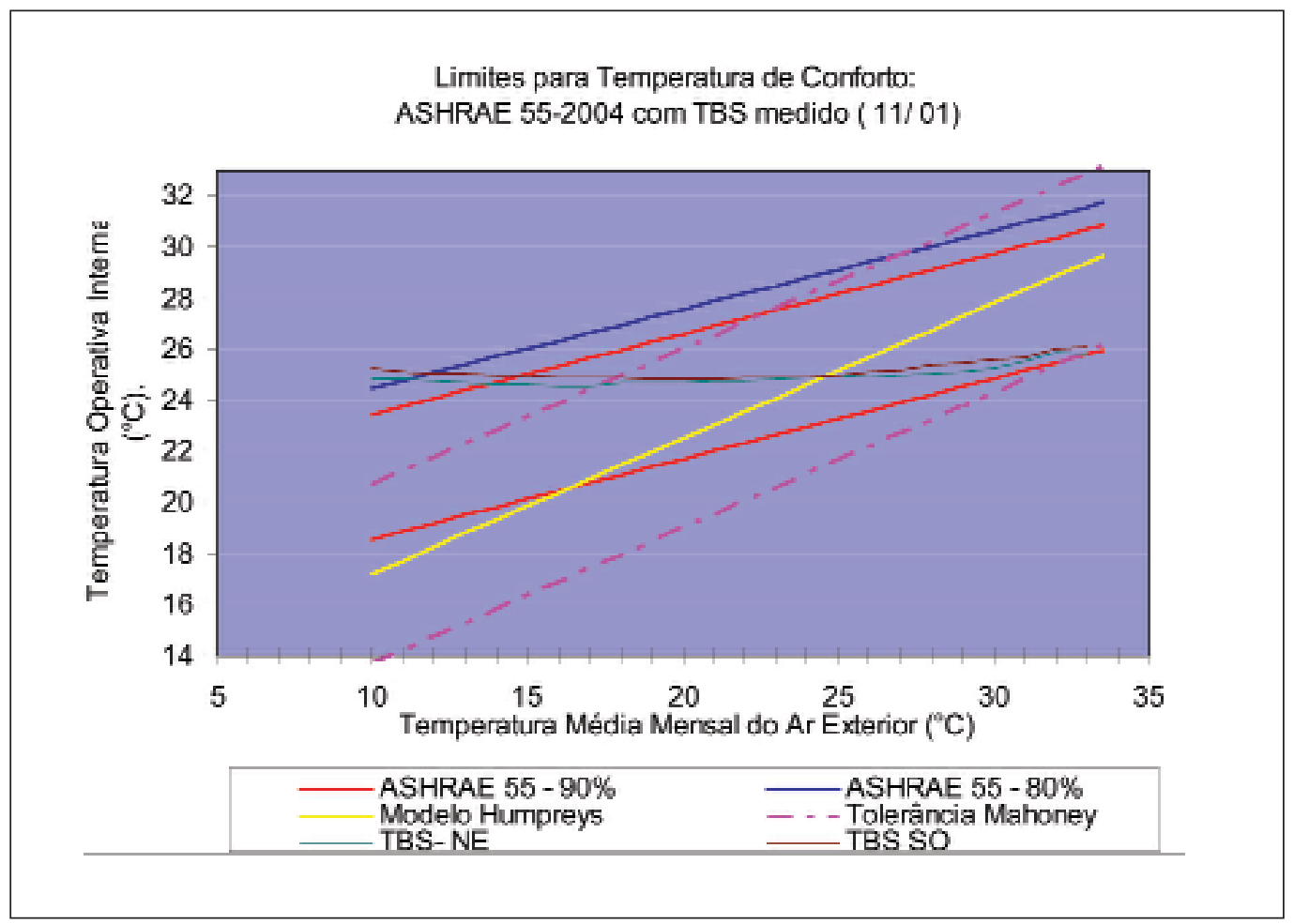

Ilustração 124: Temperatura do ar (TBS) do dia 11/01, medido, com os limites da zona de conforto determinadas pela ASHRAE 55 (2004).

abertas, para que a parcela de calor que atravessa o vidro incida sobre os materiais de revestimento e assim auxilie no aumento (desejável) da temperatura radiante média e, conseqüentemente, também nas condições de conforto térmico dos usuários. 



\section{Apêndice B \\ Questionário para o \\ "hóspede de controle"}

Fala-se aqui de ocupação controlada porque os hóspedes dos dois apartamentos utilizados foram selecionados pela aluna e seguiram as recomendações de uso e o período de acionamento de equipamentos e iluminação de acordo, tendo o manual sido entregue pela aluna antes da estada. Eles estão referenciados neste texto como hóspedes de controle.

Abaixo segue o questionário entregue aos ocupantes dos apartamentos durante sua estada no Hotel. Destaca-se o fato de que algumas informações já haviam sido pré-estabelecidas pela aluna, tais como período de entrada e saída nos apartamentos e as condições de acionamento das aberturas. 


\section{TABELA 23: QUESTIONÁRIO PARA OS “HÓSPEDES DE CONTROLE”}

DATA: ___ $/ 01 / 2007$

Tempo TOTAL:

Medição Ciclo 1:

Condições de ocupação pré-determinadas

Janelas fechadas durante o dia e a noite

Não abrir as janelas em nenhuma hipótese

Anotar o período de desconforto e o período de acionamento dos equipamentos

também do banho

Chegada: 19:30

Utilizar apartamento normalmente até as 23:30 horas, no máximo.

Indicar horário que tomou banho.

Ás 23:30 horas: Desligar TV

Pode ser mantida acesa alguma lâmpada para leitura,

mas favor notificar período de uso, caso isso seja feito.

\begin{tabular}{|c|c|}
\hline $\begin{array}{l}\text { INFORMAÇÕES DO OCUPANTE } \\
\text { Sexo: feminino } \\
\text { Idade: } \\
\text { Altura: } \\
\text { Peso: } \\
\text { Vestimenta antes de dormir: } \\
\text { (será fotografado na entrada do hotel) } \\
\text { Vestimenta para dormir: } \\
\text { (será fotografada a roupa que será utilizada) }\end{array}$ & Comentários: \\
\hline 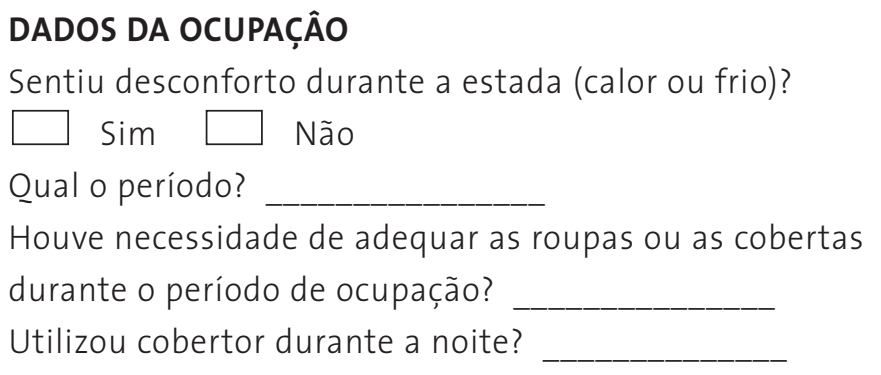 & Comentários: \\
\hline $\begin{array}{l}\text { Comentários gerais } \\
\text { Muito obrigada pela atenção! }\end{array}$ & Nome Completo: \\
\hline
\end{tabular}




\section{Apêndice C \\ Características da ocupação}

A. Vestimenta (clo) durante o descanso da noite
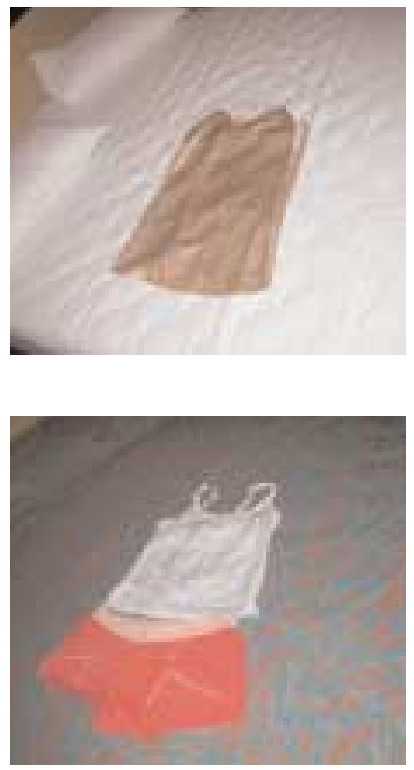

Ilustração 125: Vestimenta de dormir dos ocupantes no dia 9.
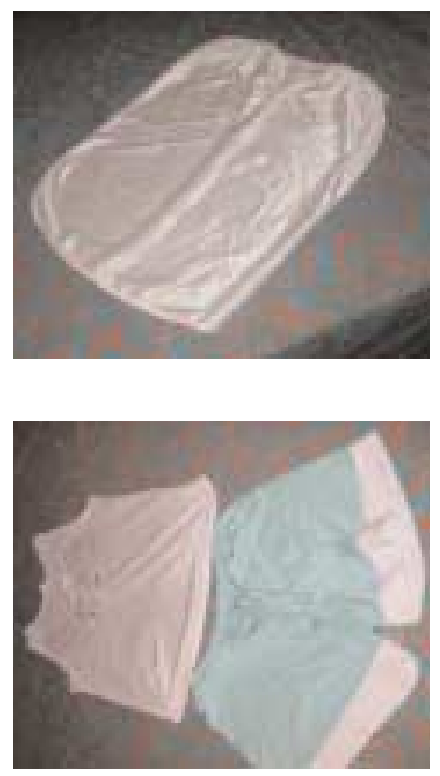

Ilustração 126: Vestimenta de dormir dos ocupantes no dia 10.
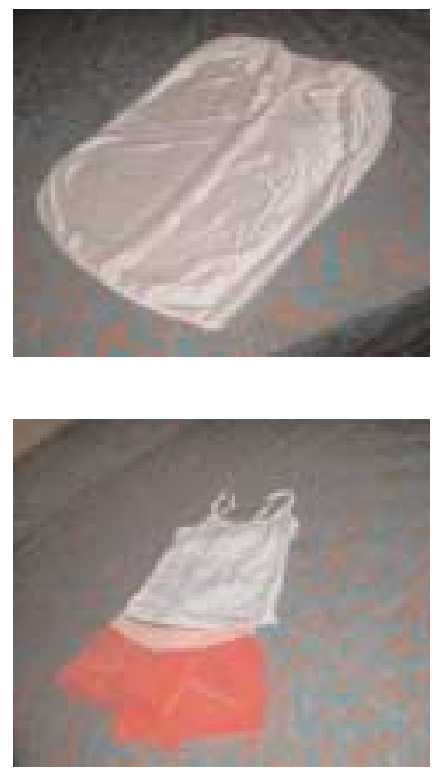

Ilustração 127: Vestimenta de dormir dos ocupantes no dia 11. 
B. “Hóspedes de Controle" na entrada do hotel (vestimenta e características físicas)

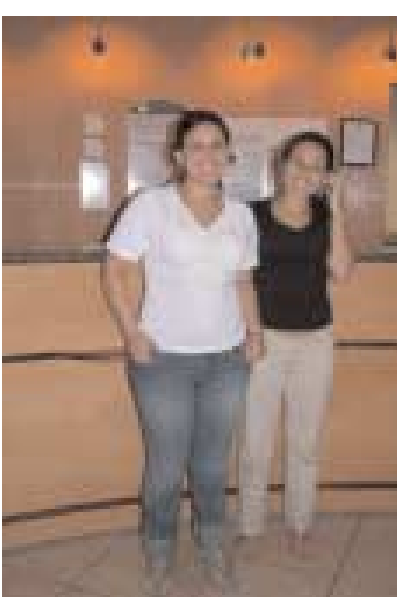

Ilustração 128: Ocupantes do primeiro dia de medições.

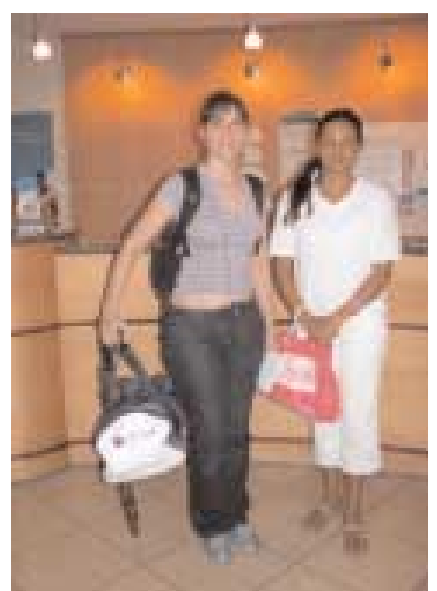

llustração 129: Ocupantes do segundo dia de medições.

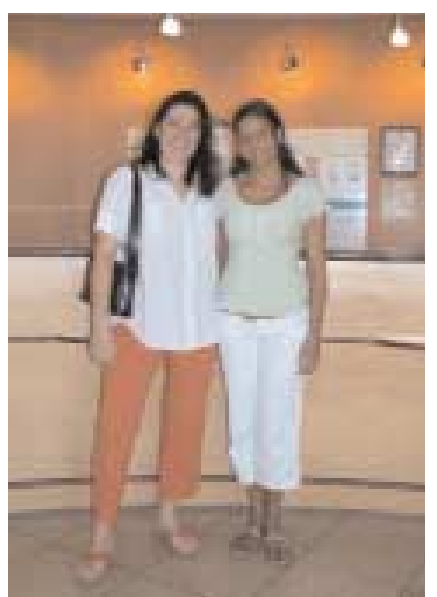

Ilustração 130: Ocupantes do terceiro dia de medições. 


\section{Apêndice D \\ Dados de entrada utilizados \\ nas simulações computacionais}

\section{TABELA 24: CONDIÇÕES INTERNAS}

\begin{tabular}{|c|c|c|c|}
\hline \multicolumn{4}{|c|}{ 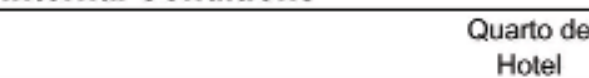 } \\
\hline & & Include Solar M & sim \\
\hline & & Weekday & sim \\
\hline & & Saturday & sim \\
\hline & & Sunday & $\operatorname{sim}$ \\
\hline \multirow{34}{*}{ 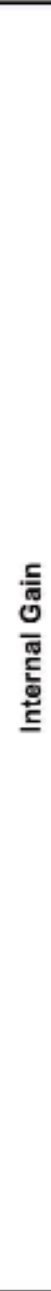 } & \multirow{3}{*}{$\begin{array}{l}\text { Radiant } \\
\text { Proportion }\end{array}$} & Lighting & 0,5 \\
\hline & & Occupant & 0,5 \\
\hline & & Equipment & 0,5 \\
\hline & \multirow{3}{*}{$\begin{array}{c}\text { View } \\
\text { Coefficient }\end{array}$} & Lighting & 0,2 \\
\hline & & Occupant & 0,2 \\
\hline & & Equipment & 0,2 \\
\hline & \multirow{4}{*}{$\begin{array}{l}\text { Infiltration } \\
\text { (ach) }\end{array}$} & Value & 0,5 \\
\hline & & Factor & 1 \\
\hline & & Setback Value & 0 \\
\hline & & Schedule & - \\
\hline & \multirow{4}{*}{$\begin{array}{l}\text { Ventilation } \\
\text { (ach) }\end{array}$} & Value & 0 \\
\hline & & Factor & 1 \\
\hline & & Setback Value & 0 \\
\hline & & Schedule & - \\
\hline & \multirow{4}{*}{$\begin{array}{l}\text { Lighting } \\
\text { Gain (w/m2) }\end{array}$} & Value & 11,85 \\
\hline & & Factor & 1 \\
\hline & & Setback Value & 0 \\
\hline & & Schedule & Luz+TV \\
\hline & \multirow{4}{*}{$\begin{array}{c}\text { Occupancy } \\
\text { Sensible } \\
\text { Gain }(w / m 2)\end{array}$} & Value & 3,31 \\
\hline & & Factor & 1 \\
\hline & & Setback Value & 0 \\
\hline & & Schedule & pessoas \\
\hline & \multirow{4}{*}{$\begin{array}{l}\text { Occupancy } \\
\text { Latent Gain } \\
\text { (w/m2) }\end{array}$} & Value & 3,31 \\
\hline & & Factor & 1 \\
\hline & & Setback Value & 0 \\
\hline & & Schedule & pessoas \\
\hline & \multirow{4}{*}{$\begin{array}{l}\text { Equipment } \\
\text { Sensible } \\
\text { Gain (w/m2) }\end{array}$} & Value & 4,71 \\
\hline & & Factor & 1 \\
\hline & & Setback Value & 0 \\
\hline & & Schedule & frigobar \\
\hline & \multirow{4}{*}{$\begin{array}{l}\text { Equipment } \\
\text { Latent Gain } \\
\text { (w/m2) }\end{array}$} & Value & 0 \\
\hline & & Factor & 1 \\
\hline & & Setback Value & 0 \\
\hline & & Schedule & - \\
\hline
\end{tabular}




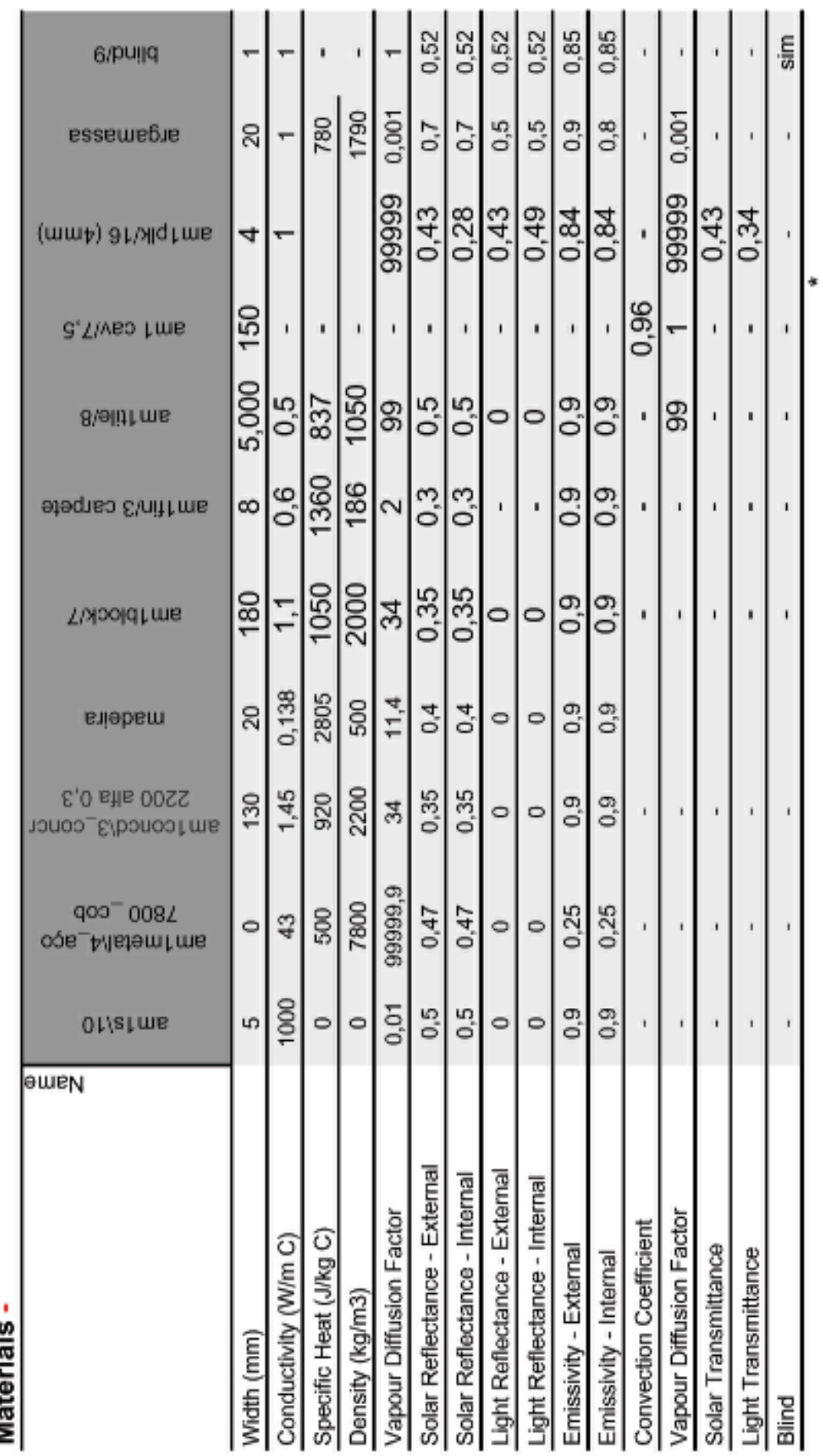




\section{TABELA 26: COMPOSIÇÃO DOS MATERIAIS}

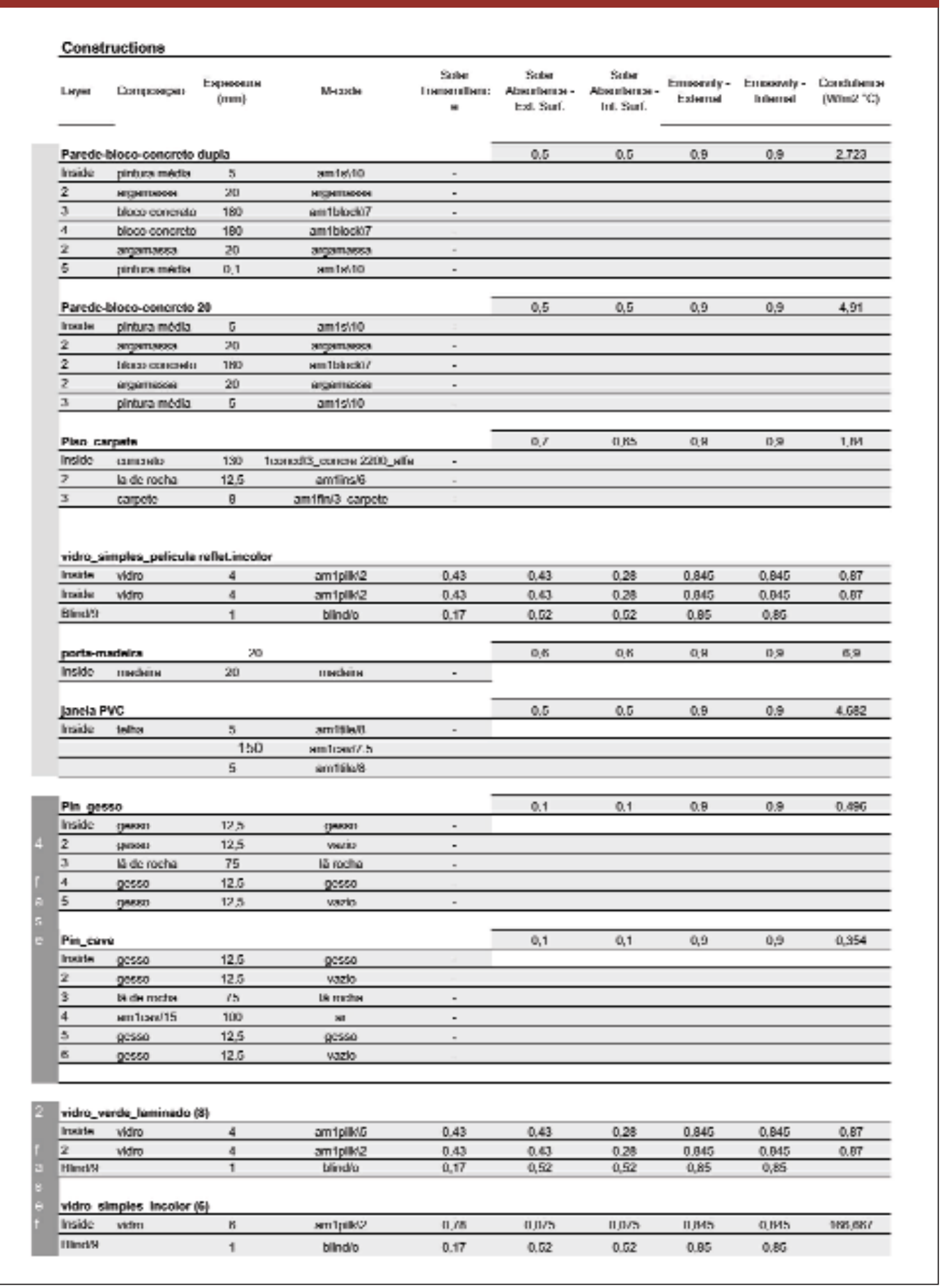




\section{TABELA 27: PROGRAMAÇÃO DE EQUUIPAMENTOS E PESSOAS (SCHEDULE)}

\section{Schedules}

\begin{tabular}{|c|c|c|c|}
\hline$\stackrel{\Phi}{\stackrel{\Phi}{\mathbb{W}}}$ & 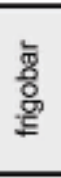 & $\begin{array}{l}\overrightarrow{+} \\
\stackrel{N}{J} \\
\exists\end{array}$ & 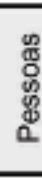 \\
\hline $0-1$ & 0 & 0 & 1 \\
\hline $1-2$ & 0 & 0 & 1 \\
\hline $2-3$ & 1 & 0 & 1 \\
\hline $3-4$ & 0 & 0 & 1 \\
\hline $4-5$ & 0 & 0 & 1 \\
\hline $5-6$ & 0 & 0 & 1 \\
\hline $6-7$ & 1 & 0 & 1 \\
\hline $7-8$ & 0 & 1 & 1 \\
\hline $8-9$ & 0 & 0 & 0 \\
\hline $9-10$ & 0 & 0 & 0 \\
\hline $11-12$ & 1 & 0 & 0 \\
\hline $12-13$ & 0 & 1 & 0 \\
\hline $13-14$ & 0 & 1 & 0 \\
\hline 14-15 & 0 & 1 & 0 \\
\hline $15-16$ & 0 & 1 & $\overline{0}$ \\
\hline $16-17$ & 0 & 0 & 0 \\
\hline $17-18$ & 0 & 0 & 0 \\
\hline $18-19$ & 0 & 0 & 0 \\
\hline $19-20$ & 0 & 1 & 0 \\
\hline 20-21 & 1 & 1 & 1 \\
\hline $21-22$ & 0 & 1 & 1 \\
\hline $22-23$ & 0 & 1 & $\overline{1}$ \\
\hline $23-0$ & 0 & 1 & 1 \\
\hline Observaçōes & & & \\
\hline
\end{tabular}





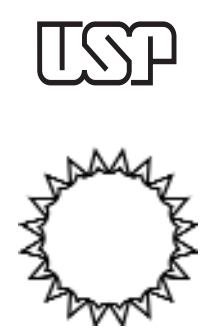

Apoio

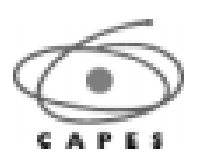

